\title{
SZTERÁNVÁZHOZ KONDENZÁLT NITROGÉNTARTALMÚ HETEROCIKLUSOK SZINTÉZISE BIFUNKCIÓS NEMI HORMON SZÁRMAZÉKOKBÓL
}

\author{
DOKTORI ÉRTEKEZÉS
}

\section{Baji Ádám}

TÉMAVEZETŐ:

Dr. Frank Éva

egyetemi docens

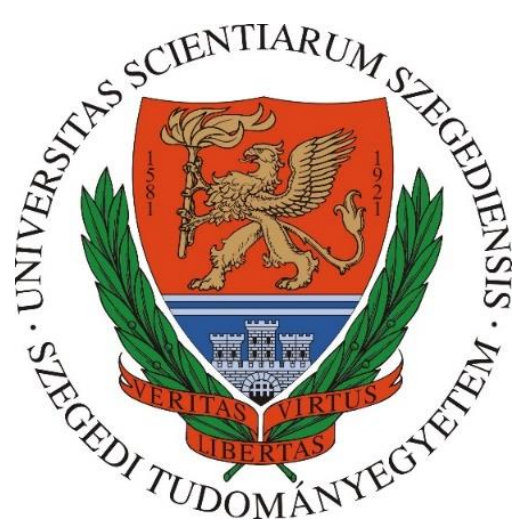

Szegedi Tudományegyetem

Természettudományi és Informatikai Kar

Szerves Kémiai Tanszék

SZTE Kémia Doktori Iskola

Szeged

2018 


\section{TARTALOMJEGYZÉK}

1. Bevezetés 1

2. Irodalmi előzmények 4

2.1. Kinolinszármazékok biológiai jelentősége és bifunkciós vegyületekből történő előállítási lehetőségei 4

2.2. Pirazolok biológiai jelentősége és előállítási lehetőségeik 8

2.3. Pirimidinszármazékok biológiai jelentősége és előállítási lehetőségeik 15

3. Célkitüzés 21

4. Kísérleti eredmények tárgyalása 22

4.1. Szteránvázhoz kondenzált kinolinszármazékok szintézise 22

4.2. Androsztánvázhoz kondenzált pirazolok szintézise 30

4.3. Szteránvázhoz kondenzált pirimidinszármazékok előállítása multikomponensü $\begin{array}{ll}\text { reakciókkal } & 40\end{array}$

5. Az in vitro farmakológiai vizsgálatok eredményei 45

6. Általános kísérleti rész $\quad 47$

7. Részletes kísérleti rész 48

8. Összefoglalás 66

$\begin{array}{ll}\text { 9. Summary } & 71\end{array}$

10. Köszönetnyilvánítás $\quad 75$

$\begin{array}{ll}\text { Felhasznált irodalmak } & 76\end{array}$

Melléklet $\quad 82$ 


\section{RöVIDÍTÉSEK JEGYZÉKE}

$\begin{array}{ll}\text { DEA } & \text { dehidroepiandroszteron } \\ \text { DHT } & \text { dihidrotesztoszteron } \\ \text { DK } & \text { diketon } \\ \text { DMF } & N, N \text {-dimetilformamid } \\ \text { IR } & \text { infravörös (infrared) } \\ \text { kat. } & \text { katalitikus mennyiségü } \\ \text { KE } & \text { keto-enol } \\ \text { MS } & \text { tömesgspektrometria (mass spectrometry) } \\ \text { MTT } & \text { 3-(4,5-dimetiltiazol-2-il)-2,5-difeniltetrazólium-bromid } \\ \text { MW } & \text { mikrohullám (microwave) } \\ \text { NMR } & \text { mágneses magrezonancia (Nuclear Magnetic Resonance) } \\ \text { ox. } & \text { oxidáció } \\ \text { rt } & \text { szobahömérséklet } \\ \text { TMSCl } & \text { trimetil-szilil-klorid } \\ \text { Ts } & \text { vékonyréteg-kromatográfia } \\ \text { VRK } & \end{array}$




\section{Bevezetés}

A szteroidok az élő szervezetekben megtalálható természetes szénvegyületek, melyek közös szerkezeti elemét egy 3 hattagú és 1 öttagú kondenzált gyürükből álló tetraciklus, az 1,2-ciklopentano-perhidrofenantrén, más néven gonánváz képezi. Az alkilszubsztituált származékok a szénatomszámuk alapján további alcsoportokba sorolhatók. A leggyakoribb alapvázakat az 1. ábra szemlélteti. A növényekben, az állatokban és a gombákban egyaránt előforduló molekulák egyes képviselőit a biológiai hatásuk alapján is rendszerezhetjük, így megkülönböztethetünk például szterineket, szívre ható glikozidokat, szteroid szaponinokat, epesavakat, mellékvesekéreg-hormonokat, szteroid alkaloidokat és nemi hormonokat. A szteránvázas vegyületek legrégebben ismert tagja az 1815-ben Chevreul által az epekőböl kristályos formában izolált koleszterin, amelynek felfedezése a tudományos közönség figyelmét a vegyületcsaládra irányította. A 19. század óta folyamatosan zajló kutatások eredményeképpen a több aszimmetriacentrumot is tartalmazó természetes szteroidok pontos térszerkezete és hatásmechanizmusa is ismertté vált. A szteránvázas vegyületek biológiai hatásának sokszínűsége az egyes molekulák különböző térszerkezetének, azaz a gyűrűk cisz vagy transz kapcsolódási módjának, a bennük található kettős kötések számának és helyének, az aromás gyürü esetleges jelenlétének, valamint a vázhoz kapcsolódó eltérő funkciós csoportok minőségének, helyzetének és térállásának köszönhető.

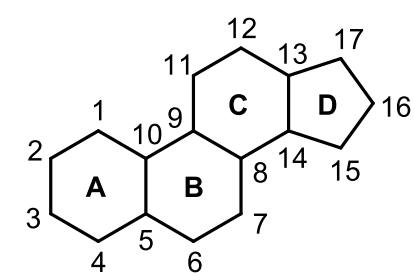

gonán

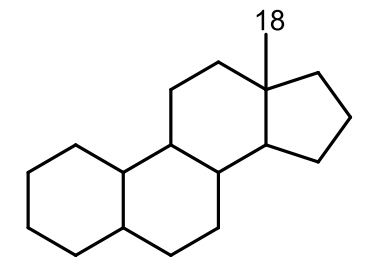

ösztrán $\left(\mathrm{C}_{18}\right)$

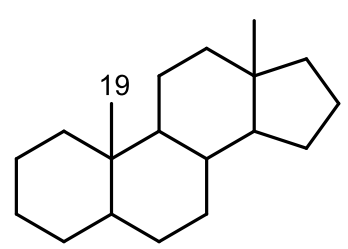

androsztán $\left(\mathrm{C}_{19}\right)$

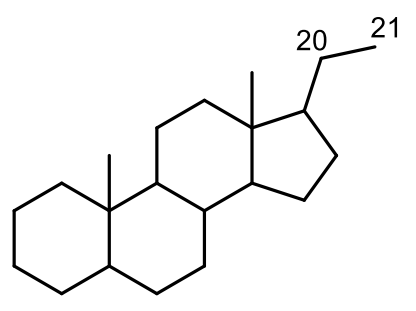

pregnán $\left(\mathrm{C}_{21}\right)$

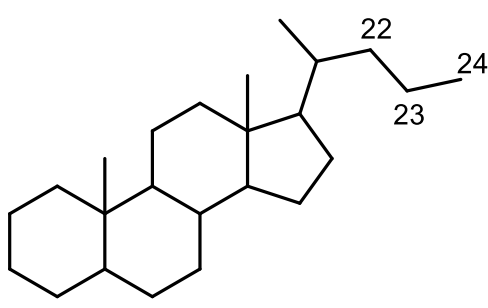

kolán $\left(\mathrm{C}_{24}\right)$

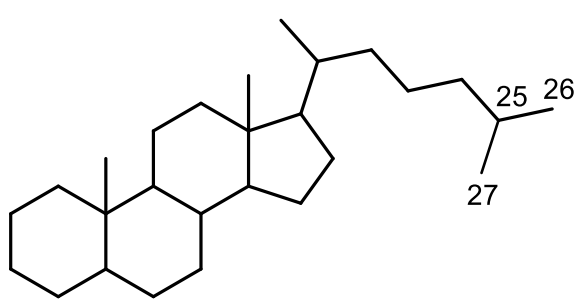

kolesztán $\left(\mathrm{C}_{27}\right)$

1. ábra: Néhány ismert szteroid alapváz

Az emberi szervezetben megtalálható szteroidok közül talán a legtöbbet a nemi hormon származékokat tanulmányozták. Ezen vegyületek főként az ivarmirigyekben, kisebb 
mennyiségben a mellékvesekéregben termelődnek. A vegyületcsoport képviselői sokrétü hatással bírnak; szerepük van a másodlagos nemi jelleg kialakításában, befolyással vannak az anyagcserére, és szabályozzák a reproduktív szervek növekedését és müködését. Az ösztrogének és a progeszteron továbbá szerepet játszanak a menstruációs ciklus szabályozásában és a terhesség fenntartásában. Az androgének anabolikus hatással is rendelkeznek, valamint az endogén szteroidogenezis során az ösztrogének előanyagaiként is felhasználódnak. ${ }^{1}$

Napjainkban a szteroidkutatás egyik fő irányát olyan félszintetikus nemi hormon származékok előállítása képezi, melyeknél a klasszikus, elsődleges hatás háttérbe szorul, vagy teljesen megszünik, és egy új, teljesen más bioaktivitás kerül előtérbe. A leggyakoribb szerkezeti módosítások a nemi hormonokon lévő 3-as, 17-es, illetve 20-as helyzetü szénatomokon már eleve meglévő funkciós csoportokat érintik. Emellett gyakori az előbb említett pozíciók szomszédos (2-es, 4-es, 16-os, 21-es) szénatomjain elvégzett szubsztitúció, kihasználva a már jelen lévő funkciós csoportok kémiai reaktivitását. Az A- és D-gyürükön végrehajtott átalakítások a könnyebb szintetikus megvalósíthatóság mellett azért is ésszerüek, mert az itt található csoportoknak alapvető szerepük van a hormonreceptorokhoz való kötődésben, így megváltoztatásukkal feltehetően a hormonális hatás is mérséklődik.

Számos kutatás igazolta, hogy a nemi hormonok szervezeten belüli mennyisége összefüggésbe hozható a rákos megbetegedésekkel, így a magas női hormonszint szerepet játszhat a mell- és petefészekrák kialakulásában, míg a megemelkedett androgén szint a prosztatarák gyakoriságát növeli. ${ }^{2-4}$ Ilyen esetekben terápiás megoldásként merülhet fel a szteroidok bioszintézisében résztvevő valamely enzim inhibíciója. ${ }^{5-7}$ Napjainkban a gyógyászatban ilyen céllal használt szerek egy része heterociklusos szteránvázas vegyület, melyek közül említésre méltó a jóindulatú prosztata megnagyobbodás kezelésére szolgáló finaszterid (5 $\alpha$-reduktáz gátló), valamint az ugyancsak forgalomban lévő, a kasztrációrezisztens prosztatarák terápiájában alkalmazott abirateron (citokróm $\mathrm{P}_{450}$-függő 17 $\alpha$-hidroxiláz-C 17,20 -liáz gátló) (2. ábra).
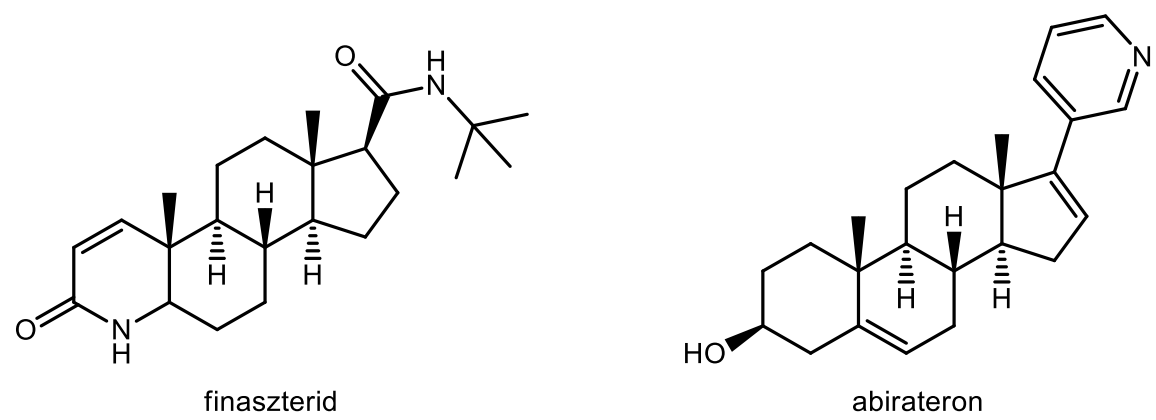

2. ábra: A gyógyászatban használt szteránvázas heterociklusok 
A daganatos megbetegedések kezelésének egy másik lehetősége a ráksejtek osztódásának közvetlen gátlása. A sejtciklus befolyásolása és a programozott sejthalál (apoptózis) előidézése megfelelő stratégia lehet ez utóbbi előidézésére. Számos, a szakirodalomban megtalálható heterociklusos szteránvázas vegyületről bizonyított, hogy direkt antiproliferatív hatással rendelkezik. ${ }^{8,9}$ A tumorellenes szerek fejlesztésére folyamatos a gyógyszeripari igény, nem csupán a nemkívánatos mellékhatások kiküszöbölése, de a ráksejtek gyors mutációja miatti rezisztencia következtében kialakuló hatáscsökkenés megakadályozása érdekében is.

A Szegedi Tudományegyetem Szerves Kémiai Tanszékén működő Szteroidkémiai Kutatócsoport évtizedek óta foglalkozik félszintetikus szteroidok előállításával. A csoport egyik kutatási irányvonalát a citosztatikus hatású nemi hormon származékok szintézise képezi. $^{10-15}$ A szerkezetmódosítások további célja az eredeti hormonális aktivitás csökkentése vagy teljes megszüntetése a nem kívánt és kellemetlen mellékhatások kiküszöbölése érdekében.

A kísérleti tapasztalatok azt mutatják, hogy az alapvegyületeken végzett egyszerübb változtatások (pl. kisméretü funkciós csoportok bevitele, telítetlenség kialakítása vagy megszüntetése) csak kismértékben befolyásolják a hormonális hatást. Jelentősebb módosítás (pl. gyürüfelnyílási vagy gyürüzárási reakciók, ${ }^{16-18}$ az alapváz geometriájának megváltoztatása, ${ }^{19}$ heteroatomok beépítése ${ }^{20}$ vagy szteroid heterociklusok kialakítása ${ }^{21-23}$ ) már nagyobb eséllyel eredményez olyan új, félszintetikus származékot, amely már nem képes kapcsolódni a hormonreceptorhoz, ugyanakkor más biológiai célmolekulával való kölcsönhatása révén egy újfajta főhatással rendelkezik. A nemi hormonok az alapvázukban található transz gyürükapcsolódás miatt síkszerü alkattal bírnak, királis jellegüknél fogva pedig jó modell vegyületekként szolgálhatnak a különböző kémiai reakciók alkalmazhatóságának tanulmányozására, e folyamatok korlátainak és szelektivitásának megismerésére.

Jelen doktori munka új típusú félszintetikus, várhatóan a hormonhatástól eltérő biológiai aktivitással rendelkező öt- és hattagú kondenzált heterociklusokat tartalmazó szteroidok szintézisén, a reakciókörülmények és a kémiai megvalósíthatóság vizsgálatán alapul. 


\section{Irodalmi előzmények}

A szerves kémiai szintézisek egyik legfontosabb célja a kezdetektől fogva olyan vegyületek keresése, melyek új fizikai, kémiai és biológiai tulajdonságokat mutatnak. A molekuláris hibridek előállítása megfelelő stratégia lehet ezen cél eléréséhez. A hibrid molekulák két vagy több különböző szerkezeti elemből épülnek fel, melyek közül legalább az egyik farmakológiai aktivitással rendelkező természetes származék. A biológiailag aktív elemek ilyen módon történő összekapcsolása más szerkezeti elemekkel napjainkban a gyógyszerkutatás, ezen belül is a rákkutatás egyik fő irányvonalát képezi. A hibridek előállításának előnye lehet, hogy az alapvegyület fizikokémiai paraméterei megváltoznak, ${ }^{24}$ ezáltal optimalizálhatók a farmakokinetikai sajátságai is. A szakirodalomban megtalálható hibrid citosztatikumok között fellelhetünk benzimidazol, kumarin, pirimidin, pirazol, kinolin, izatin és triazol egységeket tartalmazó vegyületeket is. ${ }^{25}$

A szteroidok megfelelő komponensei lehetnek a hibrid vegyületeknek. A széleskörü természetes előfordulásuk, a merev vázszerkezetük, a változatos hatásuk és a sejtmembránon való átjutási képességük mind ideális tulajdonságok a gyógyszertervezés szempontjából. ${ }^{26,27}$ Számos szteroidból képzett hibrid molekula esetén a receptorkötődés jelentősen módosul, ezáltal az alap hatástól lényegesen eltérő farmakológiai aktivitás kerül előtérbe, egy, az eredetitől eltérő biológiai támadásponton. ${ }^{28}$

Az utóbbi években számottevő figyelem irányult a szteránváz A- és D-gyürüjéhez kondenzált heterociklusok szintézisére, köztük a pirazol(in), ${ }^{10,29-31}$ az (iz)oxazol(id)in, ${ }^{32-34}$ a tiazol, ${ }^{35}$ a piri(mi)din, ${ }^{36-38}$ vagy a triazol ${ }^{39}$ gyürüt tartalmazó vegyületek előállítására. Többségükről az in vitro farmakológiai vizsgálatok során kiderült, hogy direkt antiproliferatív, illetve gyulladásgátló ${ }^{40,41}$ vagy antibakteriális ${ }^{42}$ aktivitással rendelkeznek.

\subsection{Kinolinszármazékok biológiai jelentősége és bifunkciós vegyületekből történő előállítási lehetőségei}

A kinolin egy nitrogéntartalmú aromás heterociklus, mely a piridin benzollal kondenzált származéka. Számos természetes vegyületben előfordul, melyek közül talán legismertebb a kinin. Ennek a tiszta formában kristályos alkaloidnak a láz-, és fájdalomcsillapító, valamint a gyulladáscsökkentő hatása mellett a legismertebb a malária terápiájában való felhasználása. Napjaink gyógyászatában megtalálhatók egyéb kinolin molekularészt 
tartalmazó félszintetikus és szintetikus származékok is. Említhetünk köztük továbbfejlesztett maláriaellenes hatóanyagokat (klorokin, meflokin), vírusellenes (szakinavir), antibakteriális (ciprofloxacin, sparflocaxin), kardiotóniás (karteolol), asztmaellenes (montelukast) és rákellenes (topotekán, irinotekán) szereket is (3. ábra). ${ }^{43}$<smiles>C=CC1CN2CCC1C[C@@H]2[C@H](O)c1ccnc2ccc(OC)cc12</smiles><smiles>CC(C)(C)NCC(O)COc1cccc2c1CCC(=O)N2</smiles>

karteolol<smiles>CC[C@@]1(C)C(=O)OCc2c1cc1n(c2=O)Cc2cc3c(CN(C)C)c(O)ccc3nc2-1</smiles>

topotekán<smiles>O[C@@H](c1cc(C(F)(F)F)nc2c(C(F)(F)F)cccc12)[C@H]1CCCCN1</smiles>

meflokin<smiles>O=C(O)c1cn(C2CC2)c2cc(N3CCNCC3)c(F)cc2c1=O</smiles>

ciprofloxacin<smiles>CC(C)(C)c1ccccc1CC[C@H](SCC1(CC(=O)O)CC1)c1cccc(/C=C/c2ccc3ccc(Cl)cc3n2)c1</smiles>

montelukast

3. ábra: A gyógyászatban használt néhány kinolinszármazék szerkezeti képlete

Mindezen változatos farmakológiai aktivitás ellenére a szakirodalomban kevés példa található a szteránvázhoz kondenzált kinolinszármazékok szintézisére. ${ }^{44,45}$

A kinolin és szubsztituált származékainak előállítására gyakran alkalmazott módszerek anilinből (I) és bifunkciós molekularészt tartalmazó szerves vegyületekből indulnak ki (4. ábra). A Skraup által 1880-ban kidolgozott szintézismódszer szerint az arilamint (I) nitrobenzollal, kénsavval és glicerinnel hevítve kinolin (II) izolálható a reakció termékeként. $^{46,47}$ A Gould-Jacobs módszer szerint az aromás amin (I) és az etoximetilén-malonát reakciója melegítés hatására először hidroxikarbonsav-észtert, majd ennek lúgos közegü észterhidrolízise és hő hatására bekövetkező dekarboxileződése kinolin4-olt (III) eredményez. ${ }^{48}$ Monoalkil-szubsztituált heteroaromás származékok (IV) szintézisére Doebner és Miller dolgoztak ki eljárást, melyben $\alpha, \beta$-telítetlen karbonilvegyületet reagáltatnak anilinnel (I) ${ }^{49,50}$ A Combes által megvalósított reakcióban $\beta$-diketonokból Schiff-bázis intermedieren keresztül savkatalizált gyürüzárási reakcióban 2,4-dialkilszubsztituált kinolinokat (V) lehet elöállítani. ${ }^{51,52}$ Hasonló szerkezetü köztiterméken keresztül képzett Conrad és Limpach anilinből (I) és $\beta$-ketoészterekből 2,3-diszubsztituált kinolin-4-olt (VI). ${ }^{53}$ A Doebner-reakcióban az aromás amin (I) mellett 
piroszőlősav és formilvegyület van jelen. A folyamat során alkilszubsztituált kinolinkarbonsavak (VII) keletkeznek. ${ }^{54}$

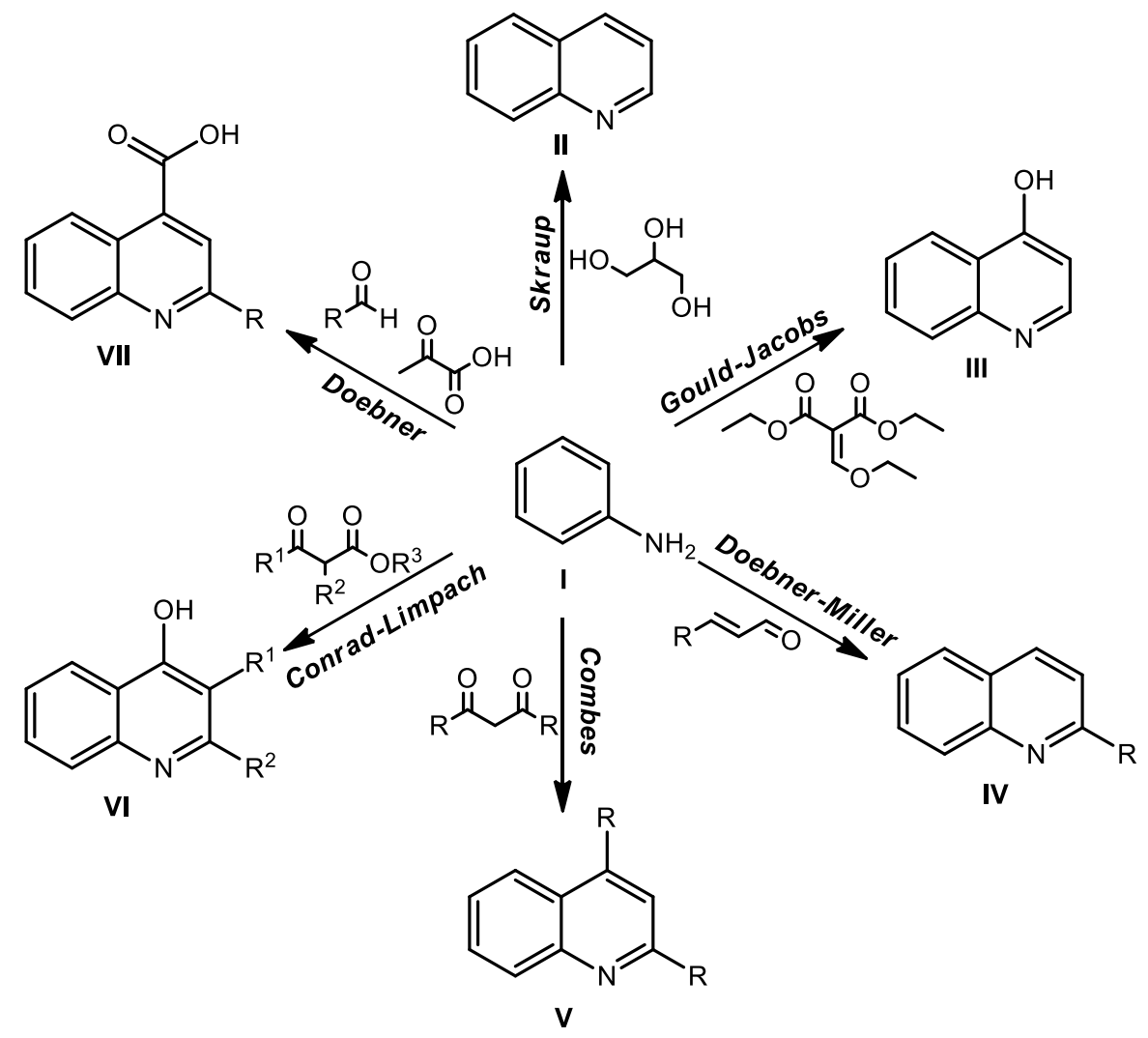

4. ábra: Kinolinszármazékok elóállítási lehetőségei anilinből és bifunkciós molekularészt tartalmazó vegyületekből

$\mathrm{Az}$ említett szintézismódszerek a sokoldalúságuk ellenére számos hátrányos tulajdonsággal rendelkeznek, mint például a többlépéses reakcióút, az erélyes reakciókörülmények, a drága adalékok és a bonyolult feldolgozási folyamatok szükségessége, valamint a termékek mindezek ellenére is alacsony hozama. Ennek hatására folyamatos a törekvés az új és „tisztább” eljárások kidolgozására a kinolin molekularészt tartalmazó származékok szintézise érdekében.

Az utóbbi években jelentős figyelem irányult a $\beta$-halovinil-aldehidekre, melyek $\alpha$-helyzetű metiléncsoportot tartalmazó ketonokból a Vilsmeier-Haack reagenssel egyszerüen előállíthatók. A reakciókban in situ képződő komplex valamilyen szervetlen savhalogenidböl $\left(\mathrm{SOCl}_{2}, \mathrm{POCl}_{3}, \mathrm{PBr}_{3}\right)$ és tercier amidból (például $N, N$-dimetilformamid (DMF)) keletkező sószerü adduktum (5. ábra). ${ }^{55}$ 


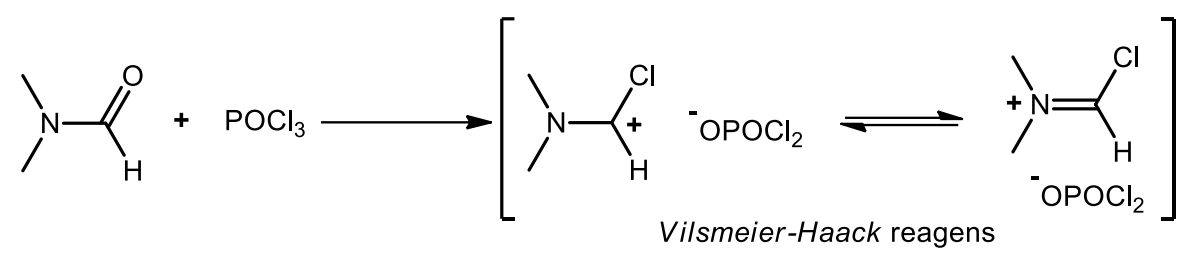

5. ábra: $\mathrm{APOCl}_{3}$ és DMF elegyéből in situ képződő reagens

$\mathrm{Az}$ alacsony hőmérsékleten, általában $\mathrm{POCl}_{3}$ és $\mathrm{DMF}$ reakciójával elöállított elektrofil sajátságú vegyület ( $N, N$-dimetil-klórmetilén-imíniumsó) a reaktivitásából adódóan igen változatos átalakításokban alkalmazható. Formilezhetők vele aromás és heteroaromás rendszerek, emellett reakcióba vihető karbonilvegyületekkel és származékaikkal is. ${ }^{56-58} \mathrm{~A}$ megfelelő szerkezetü ketonokból a reagenssel $\beta$-klórvinil-aldehidek nyerhetők, melyek azaarének szintetikus előállításakor értékes kiindulási anyagként szolgálnak. ${ }^{59-61}$

A $\beta$-halovinil-aldehid 2 ekvivalens aromás aminnal reagálva $N$-arilénaminoiminhidrogénhalogenid intermediert szolgáltat, melynek oldószeres közegü ${ }^{62}$ vagy oldószermentes ${ }^{63}$ termolízise régiószelektíven 2,3-diszubsztituált kinolint eredményez. A reakcióban 3,4-diszubsztituált heterociklusos származék keletkezését nem tapasztalták (6. ábra). Palládium(II)-acetát katalizátort alkalmazva a $\beta$-halovinil-aldehidekből szelektíven, a formilcsoporthoz képest $\beta$-helyzetü arilaminok képezhetők. ${ }^{64,65}$ A katalitikus folyamatban kapott eredmények alapján számos kutatócsoport kétlépéses szintézisút kifejlesztésén dolgozott a kinolin heterociklusok szintézisének céljából. Az $N$-arilaminovinil-aldehidek előállításához keresztkapcsolásos reakciókat alkalmaztak, majd a kapott termék savkatalizált gyürüzárásával kinolinszármazékokat nyertek. ${ }^{62}$

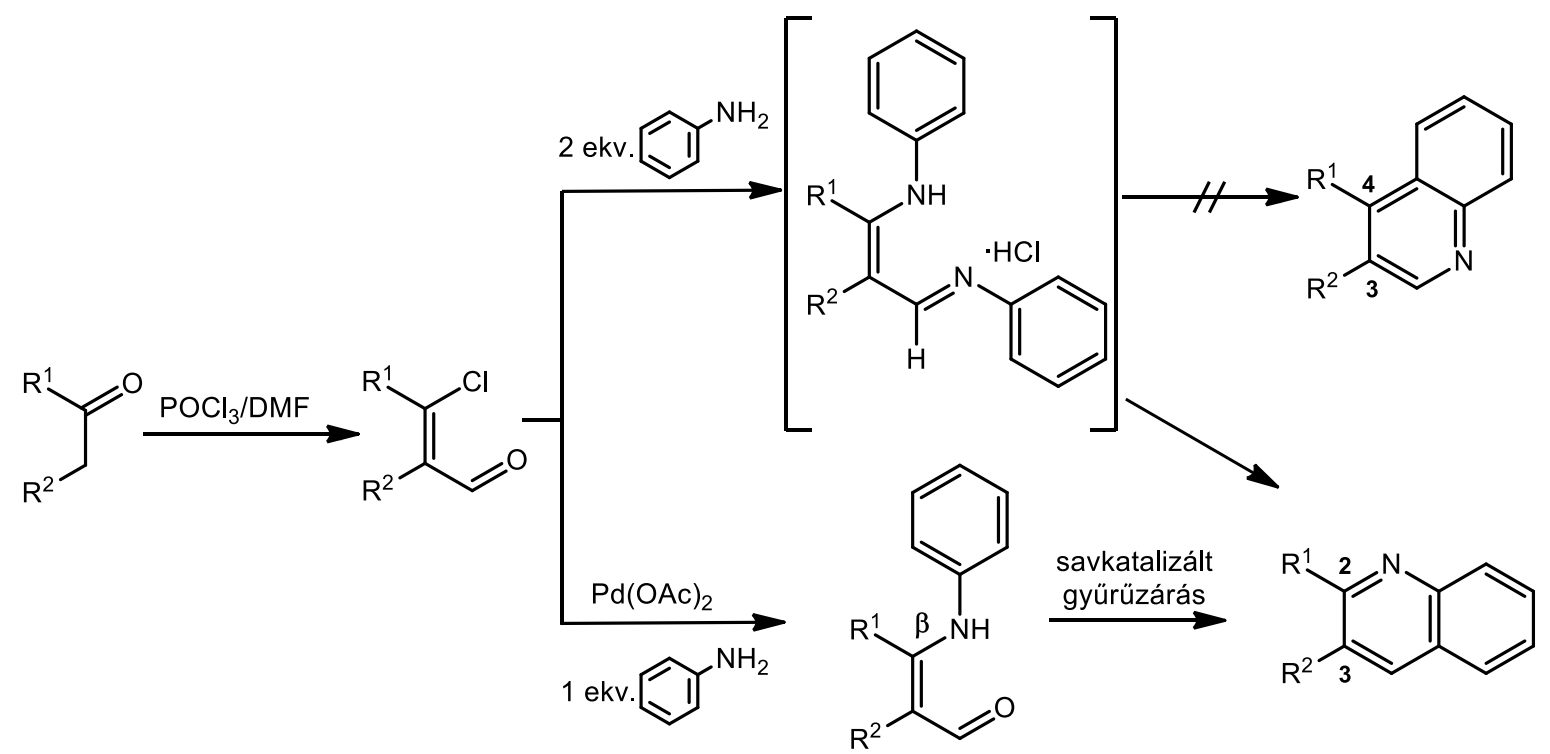

6. ábra: 2,3-diszubsztituált kinolinszármazékok előállítási lehetőségei $\beta$-klórvinil-aldehidekből 
Megkísérelték ezt a szintézisutat egy lépésben is végrehajtani, de konvencionális fütés alkalmazásakor a reakcióidő megnövekedett, ${ }^{66,67}$ míg mikrohullámú besugárzás hatására a folyamat során számos melléktermék képződését tapasztalták. ${ }^{68}$

2012-ben Gogoi és munkatársai arról számoltak be, hogy Vilsmeier-Haack reakció segítségével, $\mathrm{PBr}_{3}$ és $\mathrm{DMF}$ alkalmazásával kloroformos forralás mellett szteránvázas $\beta$-brómvinil-aldehidek szintézisét végezték el (7. ábra). ${ }^{63}$
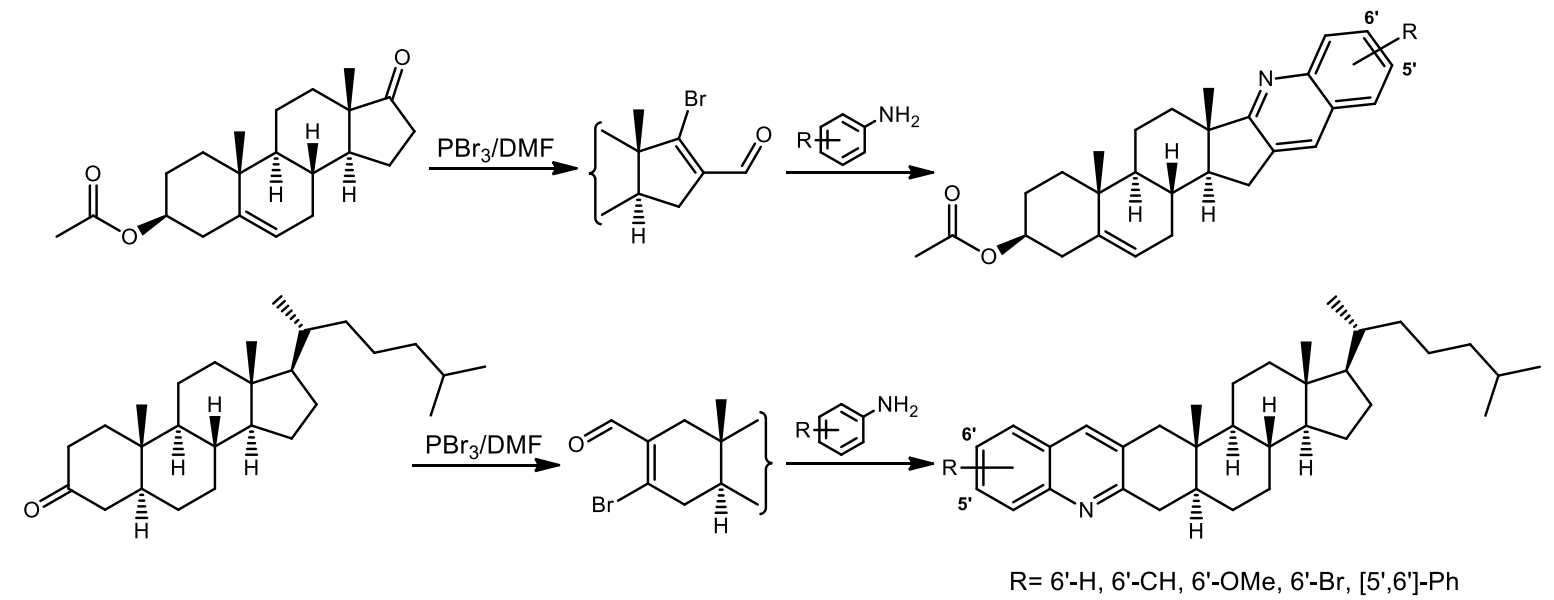

7. ábra: Szteránvázhoz kondenzált kinolinszármazékok

A dehidroepiandroszteron-3 $\beta$-acetát D-gyürüjén, valamint az 5 $\alpha$-kolesztanon A-gyürüjén kialakított bifunkciós molekularészt tartalmazó kiindulási anyagokat mikrohullámú besugárzás mellett anilinnel és különböző szubsztituált anilinszármazékokkal reagáltatták. $\mathrm{Az}$ oldószermentes közegben végzett kísérletek $\Delta^{5}$-androszténváz D- és kolesztánváz Agyürüjéhez kondenzált kinolinszármazékokat eredményeztek kiváló hozamokkal, az aromás amin szubsztituensétől függetlenül. Az előállított 10 származékot in vitro antibakteriális hatásvizsgálatnak vetették alá, mely során a dehidroepiandroszteronból képzett vegyületek közül több, a referenciaként alkalmazott aminoglikozid antibiotikummal (gentamicinszulfát) összemérhető aktivitást mutatott.

\subsection{Pirazolok biológiai jelentősége és előállítási lehetőségeik}

A pirazolok öttagú, két nitrogénatomot tartalmazó planáris szerkezetű heteroaromás vegyületek. Természetes előfordulásuk az 1950-es évekig nem volt ismert, míg 1954-ben Kosuge és Okada a kaméleonvirágból 3-n-nonilpirazolt izoláltak, megcáfolva ezzel a korábbi nézetet. Később ugyanezen kutatócsoport pirazol szerkezeti elemet tartalmazó aminosavat vont ki görögdinnye magjaiból. ${ }^{69,70}$ A szintetikus pirazolszármazékok között ismertek antibakteriális, gyulladáscsökkentő (tepoxalin, celekoxib), antidepresszáns 
(fezolamin), görcsoldó-, és rákellenes (pirazofurin) hatásúak, de a heterociklus ugyancsak megtalálható növényvédő szerekben (isolan), állatgyógyászati készítményekben és színezékekben (8. ábra). ${ }^{71-75}$<smiles>Cc1cc(=O)n(-c2ccccc2)n1C</smiles>

fenazon<smiles>CN(C)CCCn1cc(-c2ccccc2)c(-c2ccccc2)n1</smiles>

fezolamin

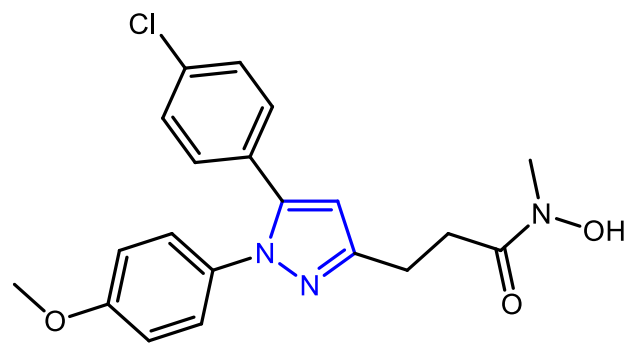

tepoxalin

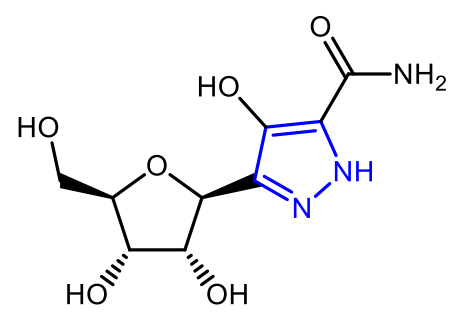

pirazofurin<smiles>Cc1cn(C(C)C)nc1OC(=O)N(C)C</smiles>

isolan<smiles>Cc1ccc(-c2cc(C(F)(F)F)nn2-c2ccc(S(N)(=O)=O)cc2)cc1</smiles>

celekoxib

8. ábra: A gyakorlatban alkalmazott néhány pirazolszármazék szerkezeti képlete

A heterogyürü szintézisét először 1883-ban Knorr végezte el, aki kinolinszármazékok előállítása közben azt tapasztalta, hogy a reakcióban 2,3-dimetil-1-fenil-3-pirazolin-5-on (fenazon) (8. ábra) keletkezik. ${ }^{76}$ Az izolált származék jelentős láz- és fájdalomcsillapító hatással rendelkezett, így a tudományos érdeklődés a pirazolkémia felé fordult. 1898-ban von Pechmann diazometánból és acetilénből sikeresen állította elő a szubsztituálatlan pirazolt. ${ }^{77}$ A szubsztituált pirazolok szintézisére számos lehetőség áll rendelkezésre. A leggyakrabban alkalmazott módszer a hidrazinból vagy szubsztituált hidrazinszármazékokból kiinduló előállítás (9. ábra). Az aldehidek tozilhidrazinnal képzett tozilhidrazonjaiból lúgos közegben in situ diazoalkán 1,3-dipólusok képződnek, melyek cikloaddíciós folyamatban terminális alkin dipolarofilekkel pirazolokat eredményeznek (9. ábra, 1. módszer). ${ }^{78}$ Hasonlóan, kétlépéses szintézisúton lehet elérni a kívánt pirazolokat, ha a hidrazinokat $\alpha, \beta$-telítetlen ketonokkal reagáltatjuk (9. ábra, 2. módszer). A folyamat első lépésében pirazolin termék keletkezik, melynek oxidációja a kívánt pirazolhoz vezet. ${ }^{79}$ 


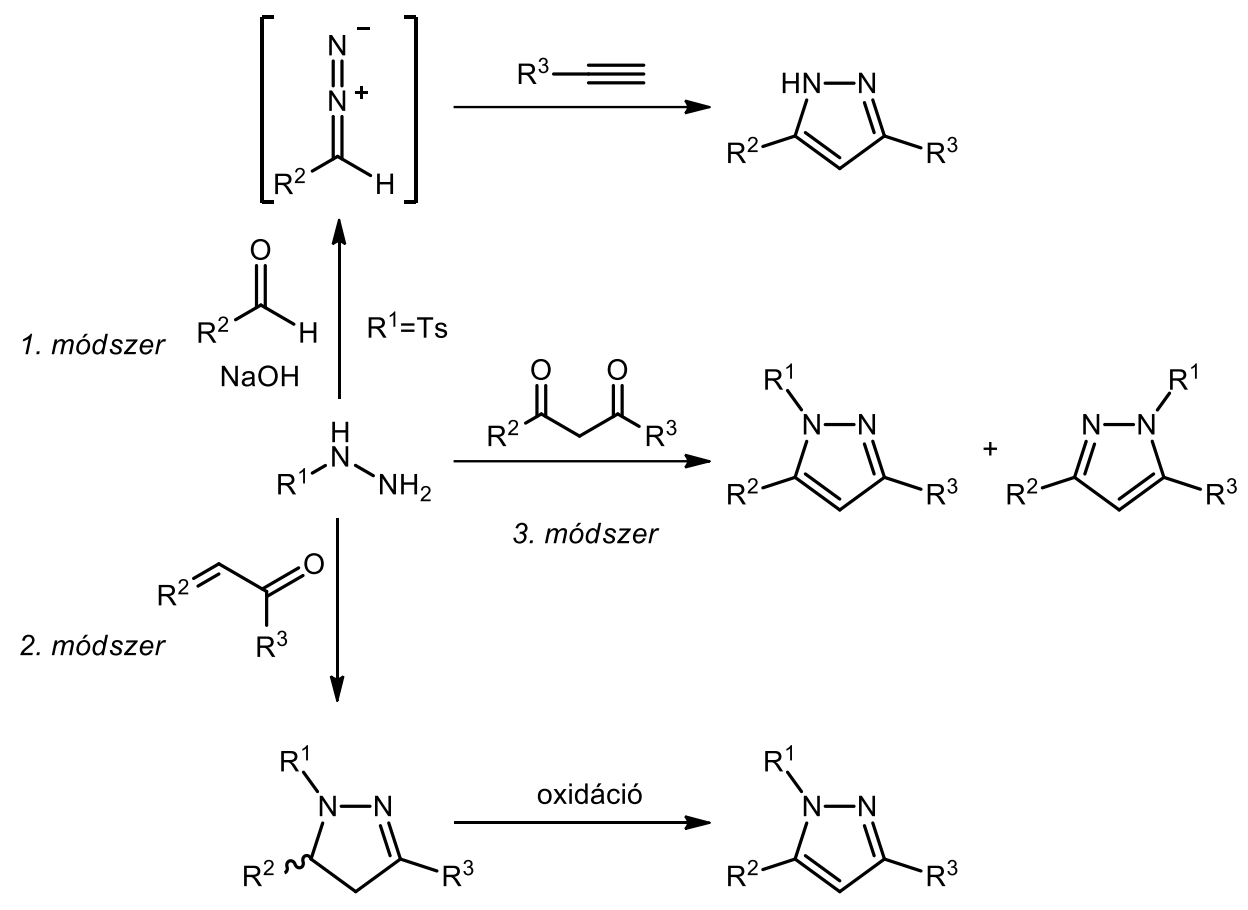

9. ábra: Szubsztituált pirazolok szintézise hidrazinszármazékokból

A heterogyürü kialakításának egyik legalkalmasabb módszere azonban máig a Knorr által kidolgozott szintézis, mely 1,3-dikarbonilvegyületek és hidrazinok savas közegű reakcióján alapul (9. ábra, 3. módszer). ${ }^{80}$ Aszimmetrikus $\beta$-diketonok esetén a folyamatban két régióizomer keletkezésére van lehetőség, azonban ezek arányai nagy mértékben függenek az alkalmazott reakciókörülményektől. A folyamat mechanizmusának felderítésére sokan tettek kísérletet. A kiindulási vegyületre jellemző tautoméria miatt aszimmetrikus molekula esetén két keto-enol (KE-1 és KE-2) és egy dikarbonil (DK) forma létezik (10. ábra). Mindhárom formának két-két aktív centruma van (A és B, C és D, E és F). A hidrazinnak a binukleofil jellegéből adódóan mindkét nitrogénje ( $\mathbf{G}$ és $\mathbf{H})$ alkalmas nukleofil addíció $\left(\mathrm{A}_{\mathrm{N}}\right)$ és 1,4-addíció kivitelezésére is, így elméletileg összesen 12 kombináció eredményezheti a termékeket. ${ }^{81}$ 


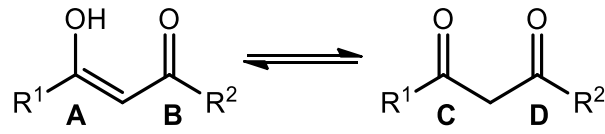

KE-1
DK<smiles>[R]NN</smiles>

G $\mathbf{H}$

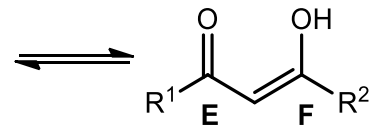

KE-2
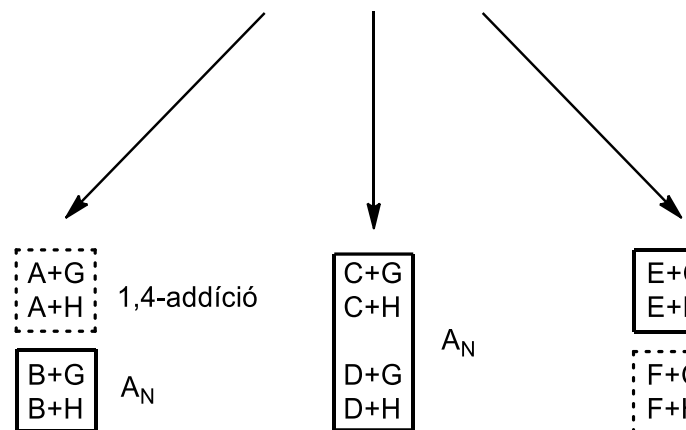

$\because \ddot{A+G}$

A+H: 1,4 -addíció

$$
B+G
$$

$\mathrm{B}+\mathrm{H} \quad \mathrm{A}_{\mathrm{N}}$

10. ábra: 1,3-dikarbonilvegyületek és hidrazinszármazékok lehetséges reakciói

Selivanov és munkatársai acetilaceton és hidrazin vagy metilhidrazin reakciójának ,stoppedflow" NMR vizsgálatakor azt tapasztalták, hogy az enolos molekularész nem reagál a hidrazinnal, amely az 1,4-aza-Michael-addíciós folyamatok lehetőségét kizárja. ${ }^{82} \mathrm{~A}$ ${ }^{1}$ H-NMR mérések alapján a reakció első két, gyors lépésében a hidrazinszármazék nukleofil addíciója 3,5-dihidroxipirazolidin köztiterméket eredményez (11. ábra).

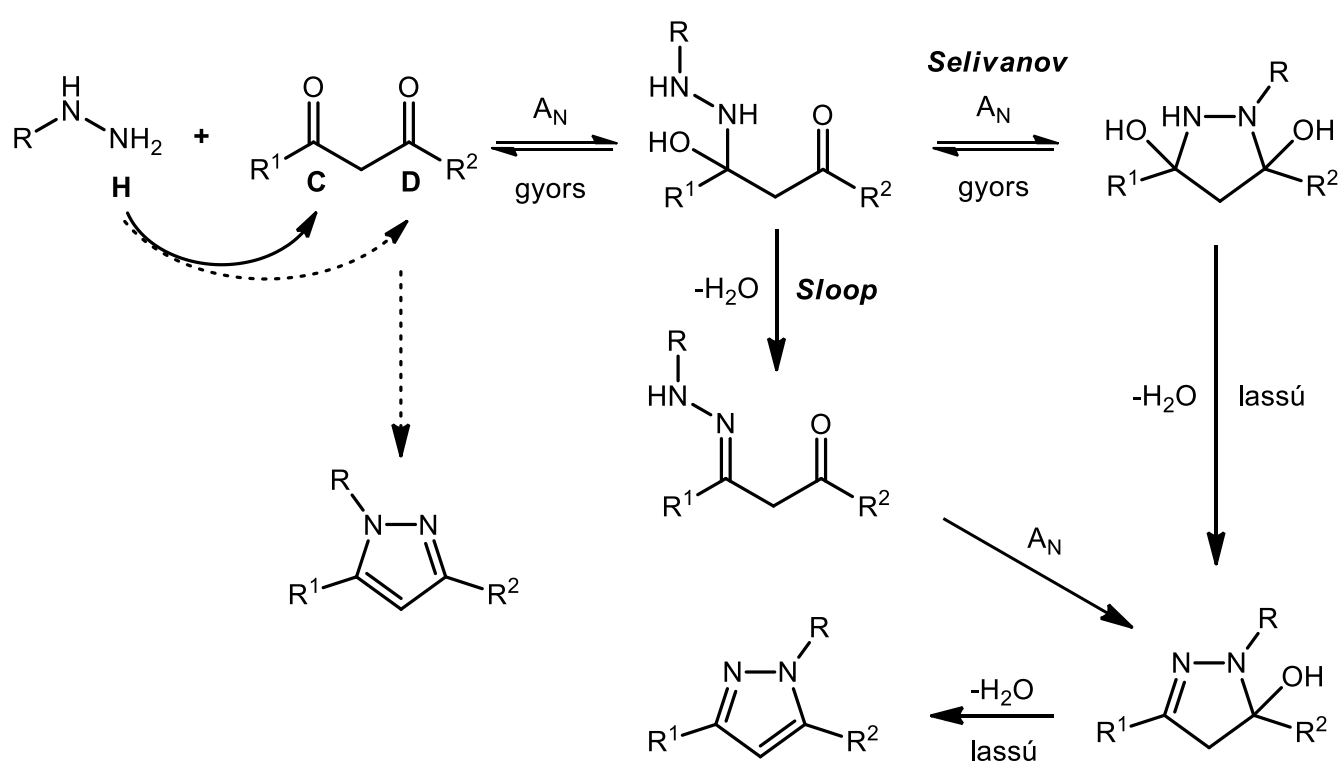

11. ábra: A dikarbonil vegyületekből képződő pirazolok reakciójának feltételezett mechanizmusai

Az ezt követő lassú vízeliminációs lépésekben először hidroxipirazolin, majd a második, szintén lassú dehidratációval pirazolszármazék képződik. Amennyiben a hidrazinszármazék 
a másik karbonilszénre (D) intéz nukleofil támadást, akkor a másik régióizomer keletkezik (11. ábra).

Sloop és munkatársai fluortartalmú 1,3-diketonok és arilhidrazinok reakcióit követték ${ }^{19}$ F-NMR spektroszkópiás módszerrel. ${ }^{83}$ A reakciók során az első nukleofil addíciós lépést követően vízeliminációt tapasztaltak, mely után egy fenilhidrazon köztiterméket tudtak kimutatni (11. ábra). A második nukleofil addíciós lépést követően a Selivanov és munkatársai által meghatározott reakcióúton zajlik tovább a folyamat, 5-hidroxi-2-pirazolin intermedieren keresztül. Ugyancsak alátámasztja a két feltételezett mechanizmust az a tény, hogy az arilhidrazinok esetén a terminális nitrogénatom $(\mathbf{H})$ nukleofilitása nagyobb, mint a köztes nitrogénatomé $(\mathbf{G})$, mivel az utóbbi elektronsürüségét a nemkötő elektronpárjának az aromás gyürüvel való konjugációja csökkenti. ${ }^{84}$

Oldat fázisban a $\beta$-dikarbonil vegyületek tautomer egyensúlyát döntően az oldószer polaritása és protikus jellege, valamint a közeg $\mathrm{pH}$-ja befolyásolja. ${ }^{83,85,86}$ A kisméretű $\mathrm{R}$ funkciós csoportokat tartalmazó vegyületek szerves oldószerekben föként - a molekulán belül kialakuló H-híd kötés miatt - a kevésbé poláris keto-enol (KE) formában vannak jelen, emellett az elegyben csak néhány százalékban létezik a dikarbonil (DK) tautomer. Az oldószer polaritásának növelésével a DK forma nagyobb oldatbeli arányával lehet számolni. Az alacsony $\mathrm{pH}$, valamint a nagyobb térkitöltésü $\mathrm{R}$ csoportok jelenléte szintén ebbe az irányba tolja el a tautomerek egyensúlyát. A $\beta$-ketoaldehidek esetén gyakran megfigyelhető, hogy az egyik pirazol régióizomer nagyobb mennyiségben keletkezik a másikhoz képest. Ez a megfigyelés az aldehid szénatom nukleofilekkel szembeni nagyobb reaktivitásával magyarázható. ${ }^{81}$ A reakció régiószelektivitását azonban az alkalmazott oldószer és a $\mathrm{pH}$ ilyen esetekben is befolyásolhatja.

Szteránvázas pirazolszármazékok szintézisére a szakirodalomban számos példa található. Fellelhetők köztük a váz A- és D-gyürüjéhez kondenzált, valamint a D-gyürűhöz kapcsolódó pirazol egységet tartalmazó vegyületek is. A Szteroidkémiai Kutatócsoportban korábban 17-exo-pirazolilszármazékok szintézisét végezték el. A vázhoz kapcsolódó heterociklusok előállításához pregnenolonból, illetve pregnadienolonból Claisenkondenzációval etil-formiáttal és nátrium-etiláttal kialakított $\beta$-ketoaldehideket használtak fel. A kiindulási bifunkciós vegyületeket ezután arilhidrazin-hidroklorid sókkal KOAc jelenlétében, ecetsavas közegben reagáltatták (12. ábra). ${ }^{87,88} \mathrm{~A}$ gyürüzárások eredményeként mindkét lehetséges régióizomer keletkezését tapasztalták. A fötermék minden esetben a 1',5'-diszubsztituált régióizomer volt, melyet az aldehid karbonil szénatomjának nagyobb reaktivitásával magyaráztak. A kísérleteket Lewis-sav $\left(\mathrm{BF}_{3} \cdot \mathrm{OEt}_{2}\right)$ 
hozzáadásával megismételve azt tapasztalták, hogy a megváltozott körülmények hatására az 1',3'-diszubsztituált izomer képződése volt számottevő. A különböző termékeloszlást a kétféle oldószerrendszerben érvényesülő eltérő tautomer egyensúllyal értelmezték.

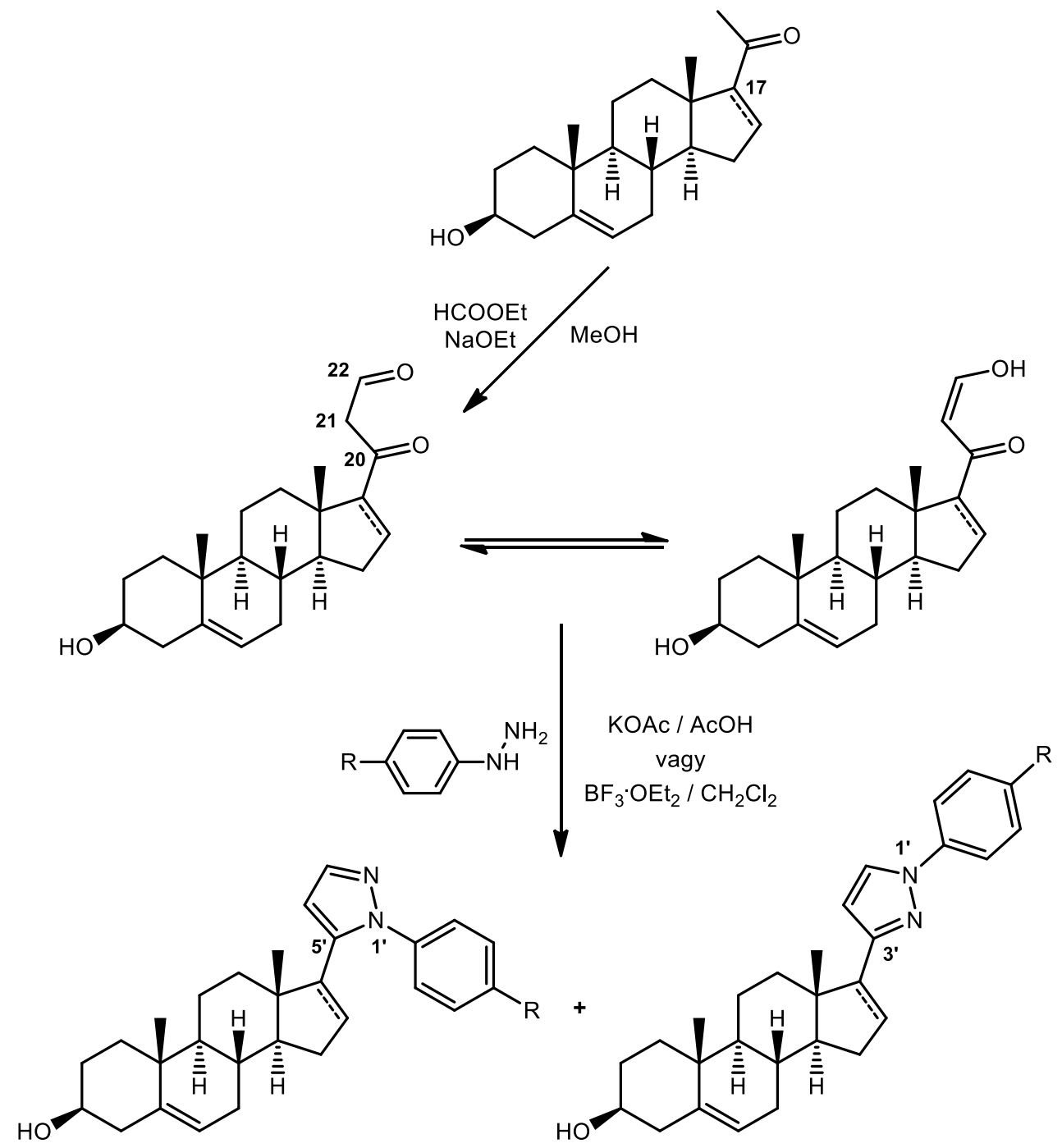

12. ábra: Szteránvázas 17-exo-pirazolilszármazékok szintézise

A gyürüzárási reakciókban ugyancsak megfigyelték az arilhidrazin fenilcsoportján lévő para-helyzetű funkciós csoport elektronikus karakterének befolyását a termékeloszlásra. Elektronvonzó szubsztituenst tartalmazó reagensek esetén az 5'-származékok, míg elektronküldő funkciós csoporttal rendelkezők esetén a 3'-pirazolil termékek nagyobb mennyiségű képződését tapasztalták. A szubsztituenshatást azzal magyarázták, hogy az elektronküldő csoportok esetén a reagens terminális nitrogénatomjának nukleofilitása megnövekszik, így a C-20 keto- és a C-22 formilcsoporttal is képes reakcióba lépni. 
Wölfling és munkatársai a 13-epi-dehidroepiandroszteron-3 $\beta$-acetátból kiindulva a szteránváz D-gyürüjén 16-os és 17-es helyzetben alakították ki a $\beta$-ketoaldehid molekularészt az előbbiekben ismertetett Claisen-kondenzációs módszerrel (13. ábra) ${ }^{89}$

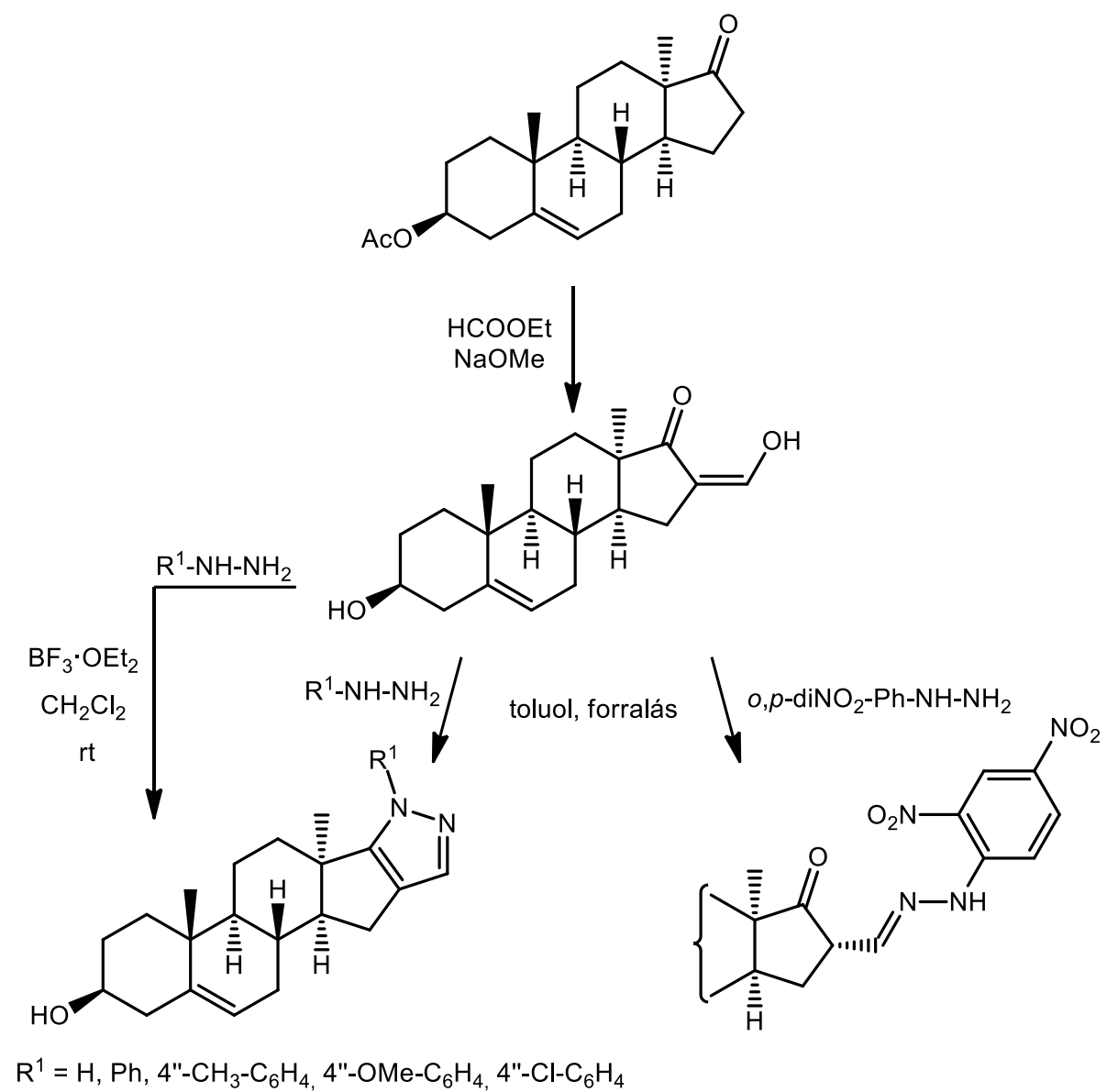

13. ábra: A 13-epi-androszt-5-én vázhoz kondenzált pirazolok szintézise

A kiindulási, bifunkciós molekularészt tartalmazó vegyület hidrazin-hidráttal, illetve szubsztituált arilhidrazinokkal végbemenő, toluolban történő forralással végzett gyürüzárása a célvegyület egyetlen régióizomerét eredményezte (13. ábra). Az o,p-dinitro-fenilhidrazin reagens használatakor azonban kizárólag fenilhidrazon keletkezett. A kondenzált heterociklus kialakítását ezután megkísérelték $\mathrm{CH}_{2} \mathrm{Cl}_{2}$ oldószerben $\mathrm{BF}_{3} \cdot \mathrm{OEt}_{2}$ hozzáadásával szobahőmérsékleten elvégezni, mely során minden esetben a kívánt pirazolszármazékot kapták.

Liu és munkatársai epiandroszteron és dehidroepiandroszteron formilezésével nyert $\beta$-ketoaldehideket fenilhidrazinnal, etanolos forralás mellett reagáltatva, régiószelektíven androsztánvázhoz kondenzált pirazolokat állítottak elő ${ }^{90}$ (14. ábra). A vegyületek egy női emlörák sejtek által is termelt angiogenezist indukáló növekedési faktor hatásos inhibitorainak bizonyultak. 


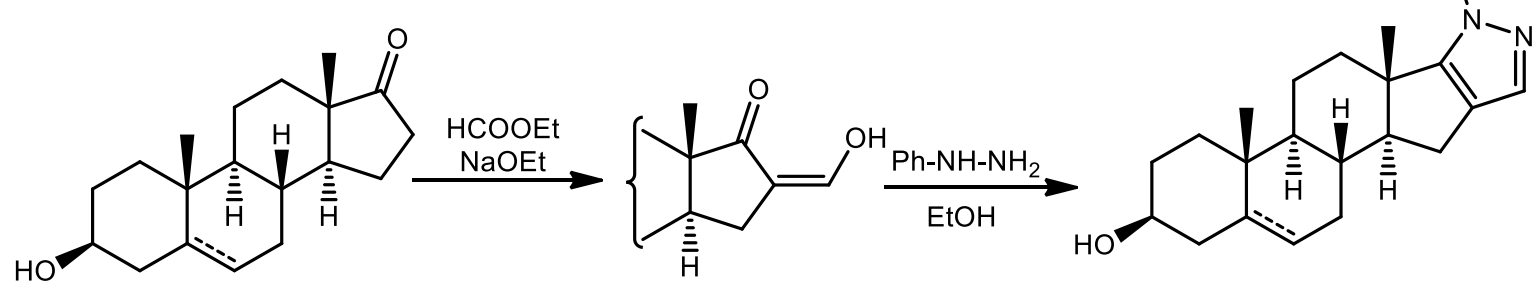

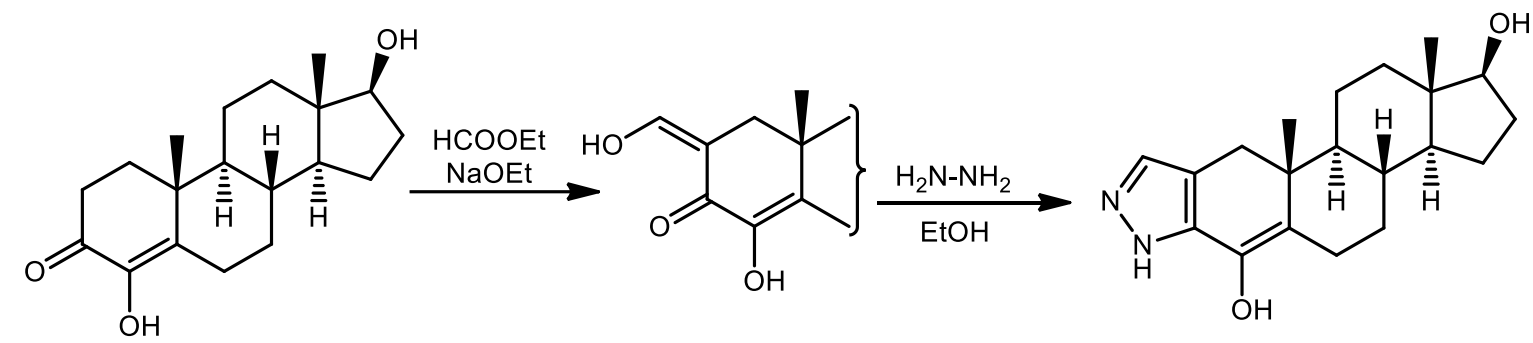

14. ábra: Szteránvázhoz kondenzált pirazolok előállítása etanolos közegben

Yadav és munkatársai a szakirodalomban kevésbé gyakori, A-gyürühöz kondenzált pirazolszármazék szintézisét végezték (14. ábra). ${ }^{7}$ A 4,17ß-dihidroxi-androszt-4-én-3-on 2-formil származékát hidrazin-hidráttal reagáltatva pirazol gyürüt alakítottak ki. Az előállított származék jelentős mértékben gátolta a szteroidok bioszintézisében résztvevő aromatáz enzim müködését.

\subsection{Pirimidinszármazékok biológiai jelentősége és előállítási lehetőségeik}

A pirimidin (1,3-diazin) egy 2 nitrogénatomot tartalmazó hattagú gyürüből álló aromás vegyület. A pirimidinek számos természetes előfordulása közül a legismertebb az örökítőanyag alkotóiként betöltött szerepük. A három pirimidin nukleobázis közül a timin csak a DNS-ben, az uracil csak az RNS-ben, a citozin mindkettőben megtalálható. A pirimidin gyürüt tartalmazó molekulák széles biológiai hatásspektrummal rendelkeznek. Számos farmakológiailag aktív vegyület tartalmazza ezt az egységet. Találhatók köztük antibakteriális (bacimetrin), antimikrobális, gyulladáscsökkentő (epirizol), rákellenes (5-fluoruracil), vírusellenes hatásúak (lamivudin, zidovudin), de a vegyületcsaládba sorolhatók a barbiturátok és a $B_{1}$-vitamin is (15. ábra). ${ }^{91-93}$ 
<smiles>O=c1[nH]cc(F)c(=O)[nH]1</smiles>

5-fluoruracil<smiles>Nc1ccn([C@H]2CS[C@@H](CO)O2)c(=O)n1</smiles>

lamivudin<smiles>COc1cc(C)nc(-n2nc(C)cc2OC)n1</smiles>

epirizol<smiles>COc1cc(C)nc(-n2nc(C)cc2OC)n1</smiles>

bacimetrin<smiles>Cc1ncc(C[n+]2csc(CCO)c2C)c(N)n1</smiles>

tiamin $\left(\mathrm{B}_{1}\right.$-vitamin)<smiles>CC1=CN2[C@H](N)[C@@H](CO)O[C@@H]2C[C@H]1N</smiles>

zidovudin

15. ábra: A gyógyászatban használt néhány pirimidinszármazék szerkezeti képlete

A pirimidin származékai már a 19. század elején ismertek voltak, első laboratóriumi szintézisükre azonban 1879-ig várni kellett, amikor Grimaux karbamidból és malonsavból barbitursavat állított elő $\mathrm{POCl}_{3}$ jelenlétében. ${ }^{94}$ A figyelem ezután a heterociklus tanulmányozására irányult, melynek hatására Pinner 1884-ben etil-acetoacetátból és szubsztituált amidinekből pirimidinszármazékokat szintetizált. ${ }^{95}$

A pirimidinre, mint hereoaromás vegyületre a nagyfokú stabilitás jellemző, így származékai szintézisére kevésbé járható az az út, mely során alapvegyületből kiindulva új szubsztituensek beépítésével hozzuk létre az új molekulát. A heterogyürün esetleg jelenlévő funkciós csoportok esetén ugyan lehetőség van keresztkapcsolásos reakcióval funkcionálni a heterociklust, de a szintetikus stratégiák zöme mégis a több reaktánsból kiinduló gyürüzárási reakciókra épül. ${ }^{96,97}$ A kétkomponensű reakciók során egy 1,3dikarbonilvegyületből (esetleg $\alpha, \beta$-telítetlen karbonilvegyületből) és egy N-C-N fragmenst (amidinek, karbamid, tiokarbamid, guanidin) tartalmazó vegyületből állíthatók elő pirimidinek. Ily módon barbitursav vagy szubsztituált származékai nyerhetők malonészter vagy helyettesített vegyületei és karbamid kétszeres nukleofil acil szubsztitúciós reakciójával (16. ábra).

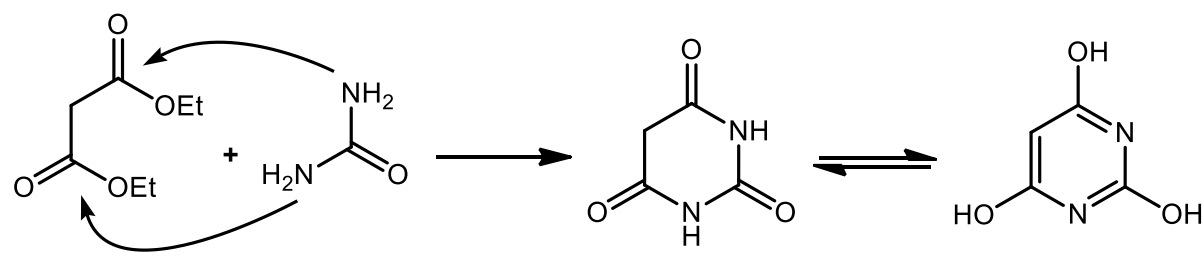

16. ábra: Barbitursav előállítása malonészterből és karbamidból 
Szteránvázhoz kondenzált pirimidinek 1,3-dikarbonil vegyületekből és N-C-N fragmenst tartalmazó származékokból történő előállításra a Szteroidkémiai Kutatócsoportban is történtek kísérletek. Vincze és munkatársai 16-hidroximetilidén-dehidroepiandroszteron és guanidínium-karbonát reakciójával az androszt-5-én váz D-gyürüjéhez kondenzált heterociklusos származékot szintetizáltak (17. ábra). ${ }^{98}$

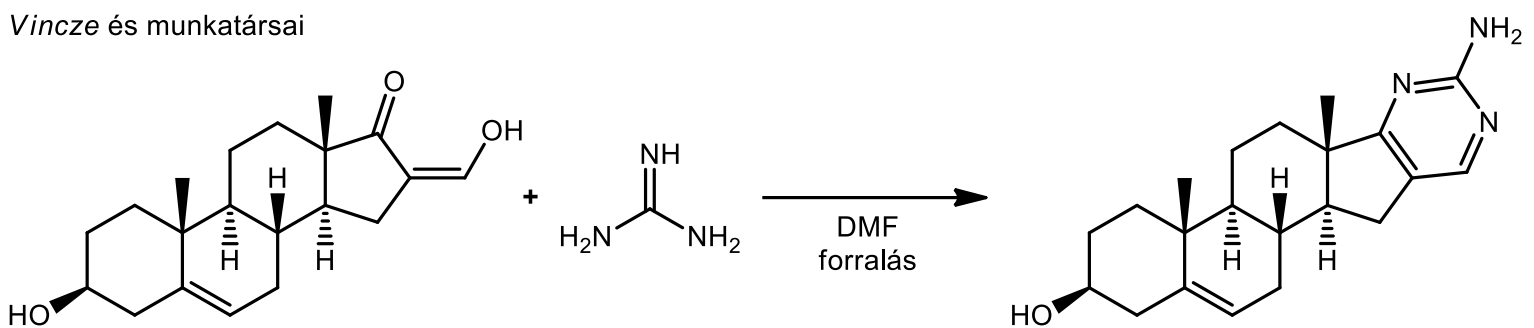

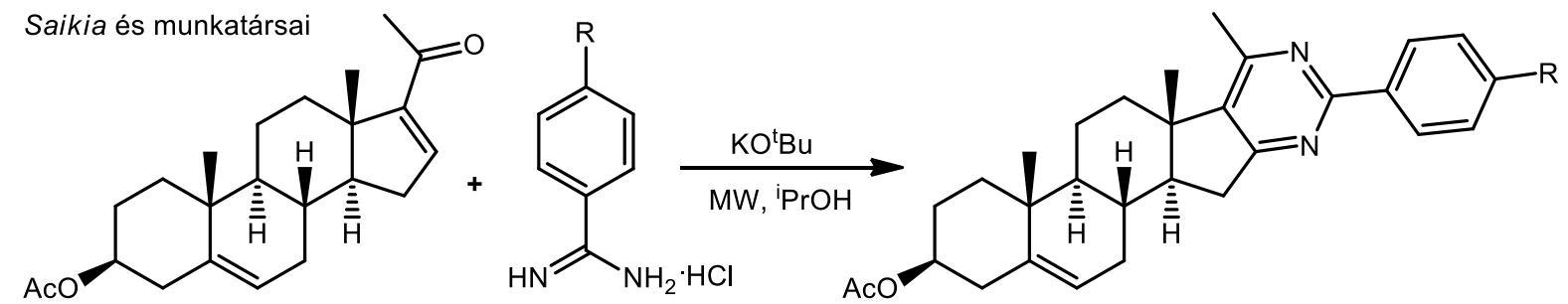

17. ábra: Szteránváz D-gyürüjéhez kondenzált pirimidinszármazékok szintézise

Saikia és munkatársai pregnadienolon-acetát és szubsztituált benzamidin-hidroklorid származékok báziskatalizált, izopropil-alkoholos közegü, mikrohullámmal aktivált reakcióival D-gyürühöz kondenzált arilpirimidineket kaptak (17. ábra). ${ }^{99}$

A heterogyürük nagymértékben funkcionalizált származékainak kialakítására jelenleg az egyik legelterjedtebb szintetikus stratégia a multikomponensü reakciók alkalmazása. ${ }^{97,100,101}$ A folyamatokban legalább három reakciópartner egyidejüleg vesz részt, melyek atomjainak nagy része beépül az újonnan képződő molekulába. A magas atomhasznosítás mellett a multikomponensü reakciók másik előnye az, hogy egylépéses folyamatok, így csökken a tisztítási müveletek száma, ezáltal idö- és költséghatékonyabbak a hagyományos kétkomponensü reakciókhoz képest.

2009-ben Barthakur és munkatársai kolesztánváz A-gyürüjéhez kondenzált pirimidinszármazékok multikomponensű reakcióval történő előállításáról számoltak be. ${ }^{102}$ A szilikagél hordozón, szilárd fázisban, 6 perces mikrohullámú besugárzással végzett szintézisek során 2-hidroximetilidén-5 $\alpha$-kolesztán-3-ont, szubsztituált benzaldehideket és ammónium-acetátot 1:2:2 mólarányban alkalmazva a kívánt kondenzált heterociklusos származékokat 78-88\%-os hozamokkal nyerték (18. ábra). 


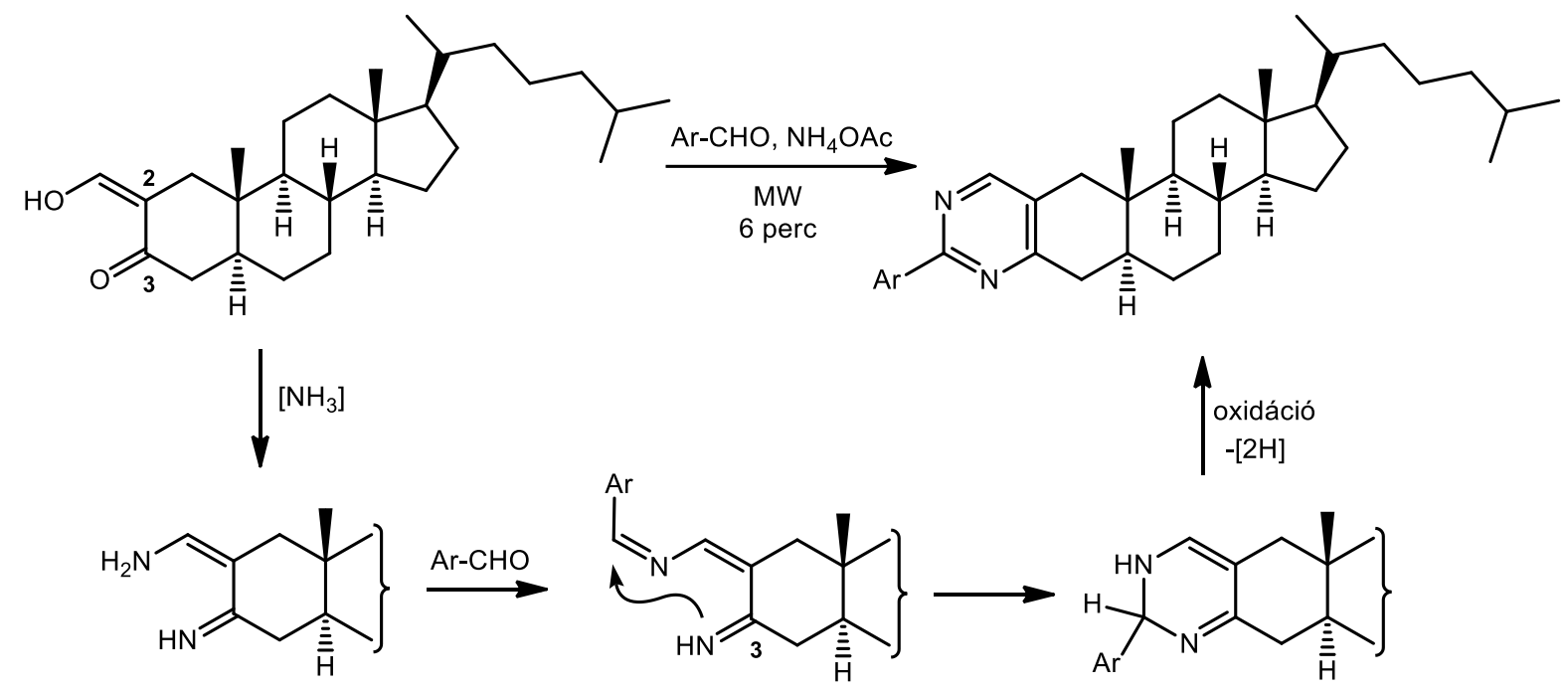

18. ábra: Kolesztánváz A-gyürüjéhez kondenzált arilpirimidinek előállítása

A reakció első lépésében a melegítés hatására az ammónium-acetátból ammónia szabadul fel, mely a formil- és karbonilcsoportokkal kondenzációs reakciókban énamino-imin molekularészt alakít ki. Az amin és az arilaldehid addícióját és egy vízkilépést követően diimin köztitermék keletkezik. A 3-as helyzetű szénatomhoz kapcsolódó imin-nitrogén nemkötő elektronpárja ezután nukleofil támadást intéz az aromás gyürü melletti parciálisan pozitív szénatomra, mely gyürüzárás után egy dihidropirimidin származékot eredményez. A folyamatot egy autooxidációs lépés zárja.

A szakirodalomban dihidropirimidinonok multikomponensű reakciókkal történő előállítására is található példa. A heterociklus kialakításának elterjedt módszere a Biginellireakció, amely egy dikarbonilvegyületből (a klasszikus reakcióban etil-acetoacetát), egy aromás aldehidből és karbamidból kiinduló, Brønsted vagy Lewis-sav által katalizálható folyamat (19. ábra). ${ }^{103-107}$<smiles>CCOC(=O)CC(C)=O</smiles><smiles>O=Cc1ccccc1</smiles><smiles>ClC1CCCCC1</smiles><smiles>CCOC(=O)C1=C(C)NC(=O)NC1c1ccccc1</smiles>

19. ábra: A klasszikus Biginelli-reakció

A reakció mechanizmusára vonatkozóan többféle teória is született, melyek közül a legismertebbek a Sweet és Fissekis által 1973-ban, valamint a Kappe által 1997-ben javasolt reakciómechanizmusok (20. ábra). ${ }^{108,109}$ A korábbi elmélet szerint az első, és egyben sebességmeghatározó lépés az etil-acetoacetát és az aldehid között végbemenő savkatalizált 
aldolkondenzáció, mely során karbokation képződik. Ezt követi a karbamid nukleofil addíciója a pozitív töltést hordozó szénatomra. A keletkező intermedier gyors dehidratáció után a kívánt dihidropirimidinont eredményezi.

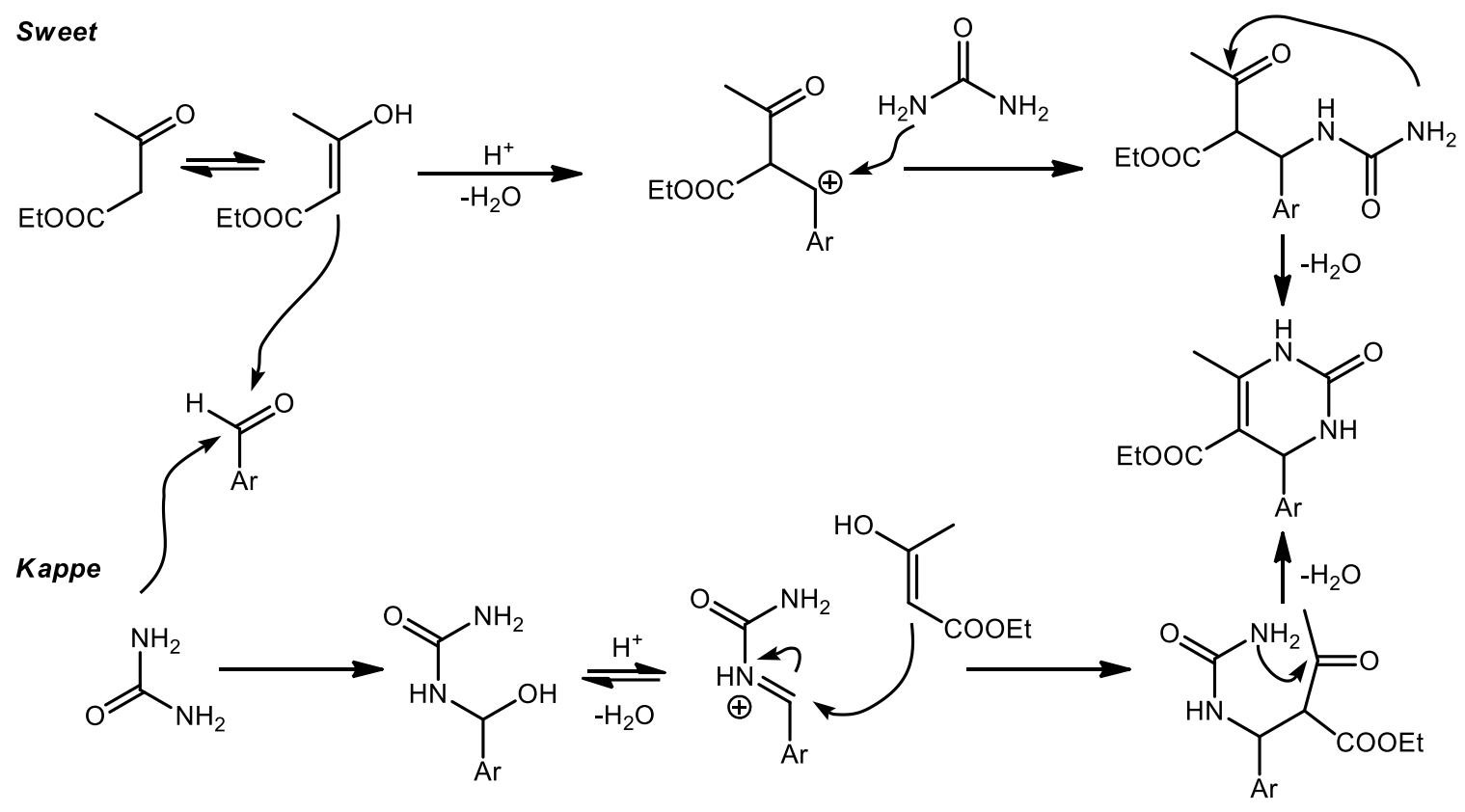

20. ábra: A Biginelli-reakció lehetséges mechanizmusai

A másik (Kappe) elmélet első lépése a karbamid nukleofil addíciója az aldehid karbonil szénatomjára. A létrejövő intermedieren protonálódást követő vízkilépés hatására kialakul egy pozitív töltésű imínium ion. Végül az etil-acetoacetát az imin szénatomjára történő addíciója és egy intramolekuláris kondenzáció vezet a heterociklushoz.<smiles>[R]NC(N)=O</smiles>

aldehid komponens:<smiles>O=Cc1ccccc1</smiles><smiles>O=Cc1ccncc1</smiles><smiles>O=Cc1cccnc1</smiles><smiles>O=C/C=C/c1ccccc1</smiles><smiles>O=Cc1cccc(C=O)c1</smiles><smiles>O=CC1=CCc2ccccc2C1=O</smiles>
aktiv metiléncsoportot tartalmazó reaktáns:<smiles>[R20]C(=O)CC([R2])=O</smiles><smiles>[R]C(=O)CC([R])=O</smiles><smiles>[R]C(=O)C[N+](=O)[O-]</smiles><smiles>O=C(/C=C/[Al])c1ccccc1</smiles><smiles>O=C1CCCC1</smiles><smiles>[R]c1ccc(C(C)=O)cc1</smiles><smiles>[R]C1([R])CC(=O)CC(=O)C1</smiles>

21. ábra: A módosított Biginelli-reakciókhoz használható komponensek néhány képviselője 
A Biginelli-reakciónak számos módosított változata ismert. Binukleofil reagensként karbamid, tiokarbamid, guanidin és ezek szubsztituált származékai, valamint amidinek, aldehid komponensként aromás és heteroaromás aldehidek, aktív metiléncsoportot tartalmazó reaktánsként pedig aldehidek, ketonok, karbonsav-észterek széles köre használható fel (21. ábra). ${ }^{105-107}$

Wang és munkatársai ösztron-3-metiléter, $3 \beta$-acetoxi-epiandroszteron és $3 \beta$-acetoxidehidroepiandroszteron kiindulási karbonilvegyületekből alakítottak ki szteránváz D-gyürüjéhez kondenzált pirimidin származékokat módosított Biginelli-reakcióval. ${ }^{37}$

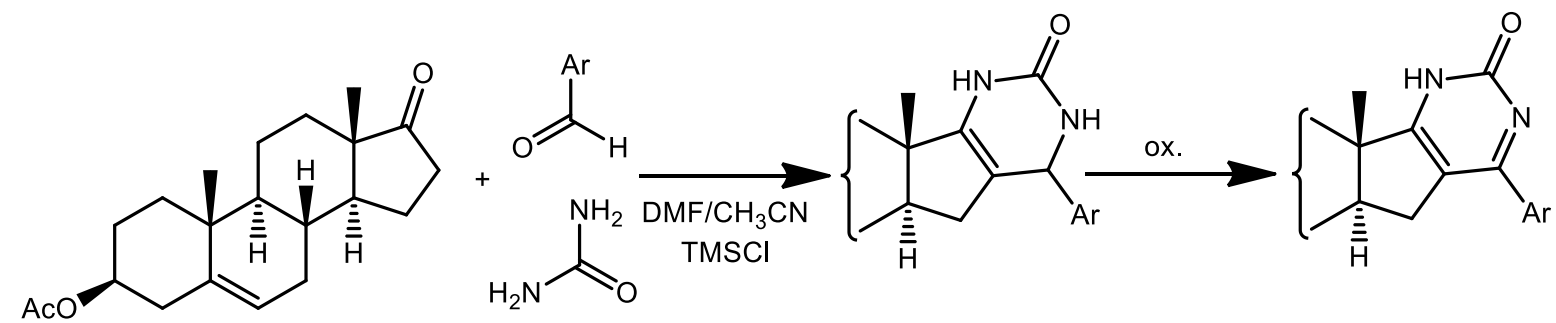

22. ábra: Szteránvázas pirimidinonok előállítása módosított Biginelli-reakcióval

A szteroidszármazékokhoz karbamidot és aromás aldehideket adtak 1:2:1,5 mólarányban, és a keveréket DMF/acetonitril oldószerelegyben trimetil-szilil-klorid (TMSCl) katalizátor jelenlétében reagáltatták. A folyamat első lépésben dihidropirimidinonokat eredményezett, melyek a levegőn állva hidroxipirimidinekké oxidálódtak.

Az irodalmi áttekintésből kitűnik, hogy a szteránváz A- és D-gyürüjéhez kondenzált heterociklusok előállítására kevés példa található. A meglévő származékok esetében sem mindig végeztek hatástani vizsgálatokat, ezért indokolt az új vegyületek szintézise és biologiai aktivitásának vizsgálata. Ugyancsak érdekes lehet a már meglévőkhöz hasonló szerkezetủ analogonok előállítása és hatástani feltérképezése is. 


\section{Célkitüzés}

Az irodalmi előzmények ismeretében doktori munkám célja új, a szakirodalomban még nem ismert, várhatóan biológiailag aktív, a szteránváz A- és D-gyürüjéhez kondenzált kinolin-, pirazol- és pirimidinszármazékok szintézise volt, bifunkciós kiindulási anyagokból. A kinolin molekularészt Vilsmeier-Haack reakcióval előállított, szteránvázas $\beta$-klórvinil-aldehidek és aromás aminok reakciójával kívántuk kialakítani. A pirazolok Knorr-típusú szintézisét 1,3-dikarbonil egységet tartalmazó szteránvázas analogonokból terveztük megvalósítani. További célként szerepelt a pirimidin heterociklus szteránvázas 1,3-dikarbonilvegyületekböl, valamint ketonokból történő előállítása multikomponensü reakciókkal, melyek során a bifunkció in situ a reakcióban képződik.

Céljaink között szerepelt az egyes reakciók körülményeinek optimalizálása és az alkalmazott reaktánsok termékhozamokra gyakorolt hatásának vizsgálata. Az előállított vegyületek szerkezetét nagymüszeres módszerekkel (NMR, MS és IR) kívántuk alátámasztani. Emellett terveztük az újonnan szintetizált származékok fizikai paramétereinek (retenciós faktor, olvadáspont) meghatározását is.

Szándékaink között szerepelt az elöállított vegyületek in vitro farmakológiai vizsgálata különböző humán daganatos sejteken a Szegedi Tudományegyetem Gyógyszerésztudományi Kar Gyógyszerhatástani és Biofarmáciai Intézetével, valamint a Szegedi Tudományegyetem Természettudományi és Informatikai Kar Biokémiai és Molekuláris Biológiai Tanszékével való együttmüködések keretében. 


\section{Kísérleti eredmények tárgyalása}

\subsection{Szteránvázhoz kondenzált kinolinszármazékok szintézise ${ }^{110}$}

Kísérleti munkánk első részében ösztránváz D-gyürüjéhez kondenzált kinolinszármazékok szintézisét végeztük el. A heterogyürü kialakításához szükséges kiindulási anyagot (2) ösztron-3-metil-éterböl (1) kloroformban, Vilsmeier-Haack reagens ( $\mathrm{POCl}_{3}$ és $\mathrm{DMF}$ ) hozzáadása mellett, 4 órás forralással állítottuk elő. A reakcióban a kívánt $\beta$-klórvinilaldehid (2) mellett kis mennyiségben vinil-halogenid melléktermék (3) keletkezését is tapasztaltuk (23. ábra). ${ }^{111}$

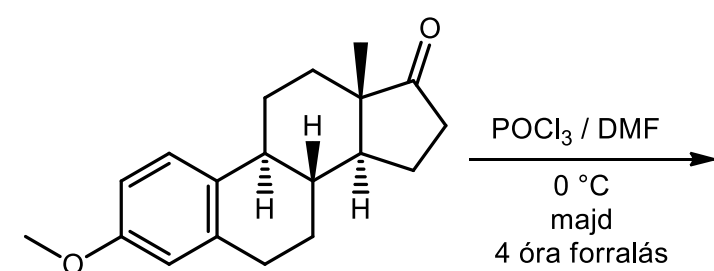

1

\begin{tabular}{ccccc}
\hline $\begin{array}{c}\text { Aromás } \\
\text { amin }\end{array}$ & $\begin{array}{c}\text { Reakcióidő } \\
\text { (perc) }\end{array}$ & Termék & $\mathrm{R}$ & $\begin{array}{c}\text { Hozam } \\
(\%)\end{array}$ \\
\hline $\mathbf{4 a}$ & 20 & $\mathbf{5 a}$ & $\mathrm{H}$ & 53 \\
$\mathbf{4 b}$ & 10 & $\mathbf{5 b}$ & $\mathrm{CH}_{3}$ & 54 \\
$\mathbf{4 c}$ & 10 & $\mathbf{5 c}$ & $\mathrm{OMe}^{\mathrm{M}}$ & $\mathbf{4 7}$ \\
\hline
\end{tabular}

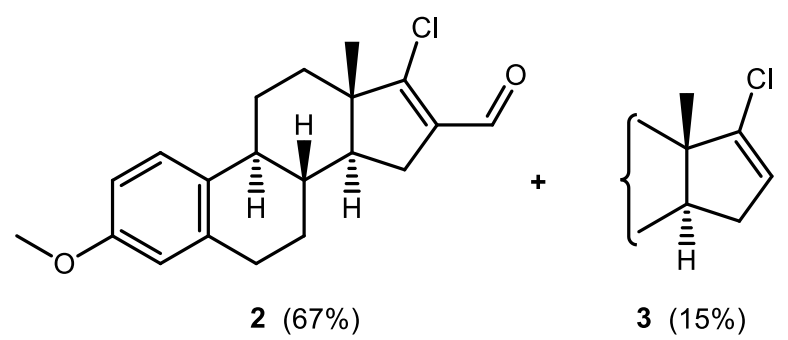<smiles>[R]c1ccc(N)cc1</smiles>

23. ábra: Ösztránvázas kinolinok szintézise

A heterociklizációt első lépésben a szakirodalomból már ismert, Gogoi és munkatársai által az androsztánváz D-gyürüjén kidolgozott oldószermentes körülmények alkalmazásával kívántuk elvégezni. ${ }^{63}$ A $140{ }^{\circ} \mathrm{C}$-on, mikrohullámú besugárzással végrehajtott reakcióban az ösztránvázas bifunkciós vegyülethez (2) 2 ekvivalens mennyiségü anilint (4a) adtunk. A reakcióidő elteltével a vékonyréteg-kromatográfiás (VRK) ellenőrzés során számos nem azonosított melléktermék keletkezését tapasztaltuk, mely a további tisztítást és a termék kinyerését megnehezítette. A reakciót ezért 1 ekvivalens anilin alkalmazásával DMF-ben megismételtük (23. ábra), mely jó oldószernek bizonyult hasonló reakciókban. ${ }^{62,112} \mathrm{Az}$ oldószermentes körülményekkel azonos hőmérsékleten és megegyező ideig végzett kísérletet követően a VRK szerint lényegesen csökkent a melléktermékek száma, de a teljes konverzió eléréséhez további 10 perc reakcióidőre volt szükség. A kromatogramon jelentkező fö folt mellett néhány polárisabb termék jelenlétét figyeltük meg, de ezek 
mennyisége a reakcióidő növelésével sem változott. Az oszlopkromatográfiás tisztítást követően az ösztránváz D-gyürüjéhez kondenzált kinolinszármazékot (5a) 53\%-os hozammal nyertük. A kapott termék mennyiségét kétszeres reagensfelesleg (4a) alkalmazásával sem sikerült tovább növelni.
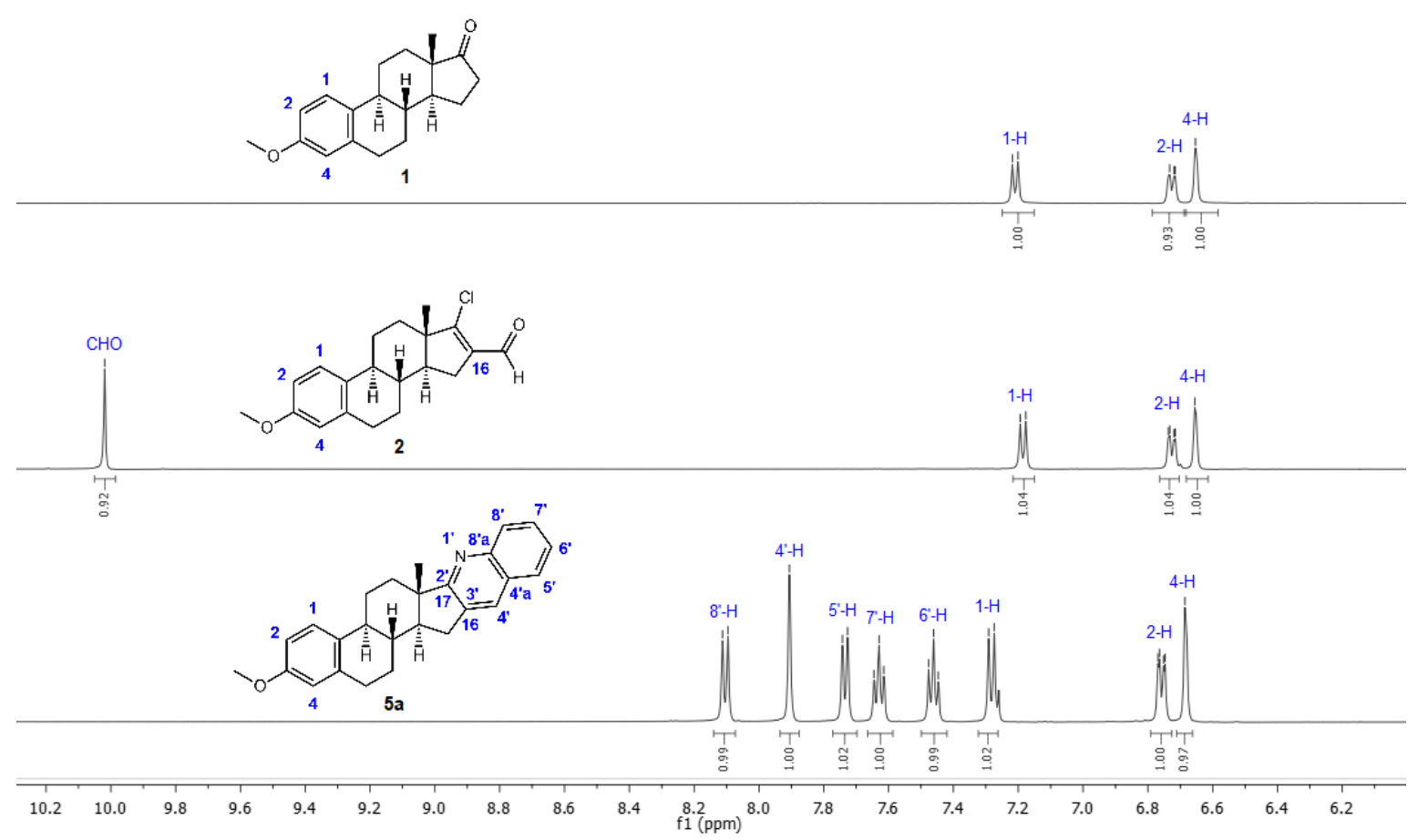

24. ábra: Az ösztron-3-metil-éter (1), az ösztránvázas $\beta$-klórvinil-aldehid (2) és az előállított Dgyürühöz kondenzált kinolinszármazék (5a) ${ }^{1} \mathrm{H}-\mathrm{NMR}$ spektrumainak aromás tartománya

A 24. ábrán az alapvegyületként szolgáló ösztron-3-metil-éter (1), a kiindulási bifunkciós vegyület (2) és a belőle anilinnel előállított heterociklusos származék (5a) ${ }^{1} \mathrm{H}-\mathrm{NMR}$ spektrumainak részletei láthatók. A Vilsmeier-Haack reakcióval kapott $\beta$-klórvinil-aldehid származék (2) spektrumán 10 ppm felett egy szingulett jel látható, mely a 16-os helyzetü formilcsoport jelenlétére utal. A vegyület (2) anilinnel (4a) történő reakciója után az elöbb említett csúcs már nem található meg a spektrumon, ami a gyürüzárást igazolja. További bizonyíték a kondenzált heterociklus (5a) kialakulására az aromás tartományban 7,4 és 8,2 ppm között jelentkező 5 új jel (a 4'-H szingulettje, a 5'-H és a 8'-H dublettjei, valamint a 6'-H és a 7'-H triplett jelei).

A továbbiakban a reakciót elvégeztük para-helyzetben elektronküldő csoportot tartalmazó anilinszármazékokkal $(\mathbf{4 b}, \mathbf{4 c})$ is. Azt tapasztaltuk, hogy mindkét esetben 10 perc alatt a kívánt heterociklusos származékok (5b, 5c) keletkeztek. Orto-toluidin alkalmazásakor ugyanakkor 30 perces reakcióidőt követően sem volt termékképződés, mely 
az aromás gyürün található szubsztituens gyürüzárást gátló sztérikus hatásának tulajdonítható. Elektronvonzó csoportot tartalmazó reagensek (4-klóranilin, 4-nitroanilin) esetén a reakcióban keletkező intermedierek és termékek a feldolgozási vagy tisztítási lépések során elbomlottak.

A szteránváz részben vagy teljesen telített A- és D-gyürüjének azonos reakciókörülmények közötti eltérő viselkedését már korábban megfigyelték. ${ }^{12,14}$ Az öttagú D-gyürű a nagyobb merevsége és a 13-as helyzetben lévő anguláris metilcsoport jelenléte miatt esetenként kisebb reaktivitást mutat, mint a hattagú, flexibilisebb A-gyürü. Tekintettel arra, hogy az ösztránváz D-gyürüjéhez kondenzált kinolinokat (5a-c) közepes hozamokkal kaptuk, a továbbiakban olyan próbareakciók elvégzése mellett döntöttünk, amelyekben a szteránváz hattagú A-gyürüjének modellezésére a 6-metoxi-tetralont (6) használtuk (25. ábra).

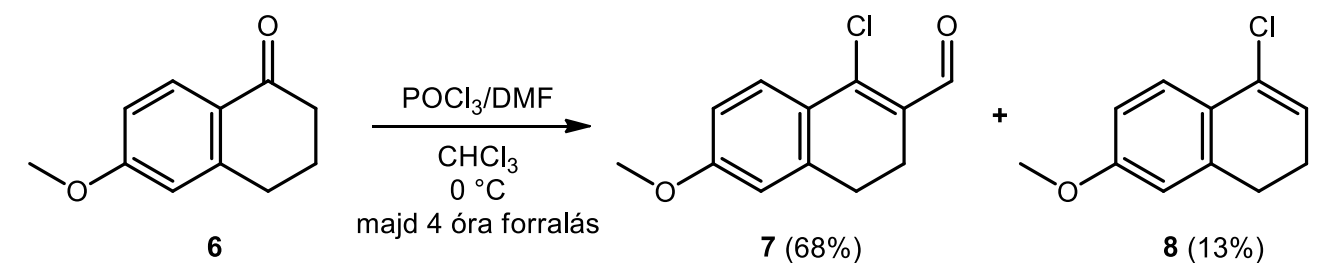

\begin{tabular}{cccccc}
\hline $\begin{array}{c}\text { Aromás } \\
\text { amin }\end{array}$ & $\begin{array}{c}\text { Reakcióidö } \\
\text { (perc) }\end{array}$ & Termék & $\mathrm{R}^{1}$ & $\mathrm{R}^{2}$ & $\begin{array}{c}\text { Hozam } \\
(\%)\end{array}$ \\
\hline $\mathbf{4 a}$ & $\mathbf{5}$ & $\mathbf{9 a}$ & $\mathrm{H}$ & $\mathrm{H}$ & 76 \\
$\mathbf{4 b}$ & 2 & $\mathbf{9 b}$ & $\mathrm{H}$ & $\mathrm{CH}_{3}$ & 90 \\
$\mathbf{4 c}$ & 2 & $\mathbf{9 c}$ & $\mathrm{H}$ & $\mathrm{OMe}$ & 89 \\
$\mathbf{4 d}$ & 20 & $\mathbf{9 d}$ & $\mathrm{Cl}$ & $\mathrm{H}$ & 35 \\
$\mathbf{4 e}$ & 10 & $\mathbf{9 e}$ & $\mathrm{H}$ & $\mathrm{Cl}$ & 54 \\
$\mathbf{4 f}$ & 10 & $\mathbf{9 f}$ & $\mathrm{H}$ & $\mathrm{Br}$ & 62 \\
\hline
\end{tabular}

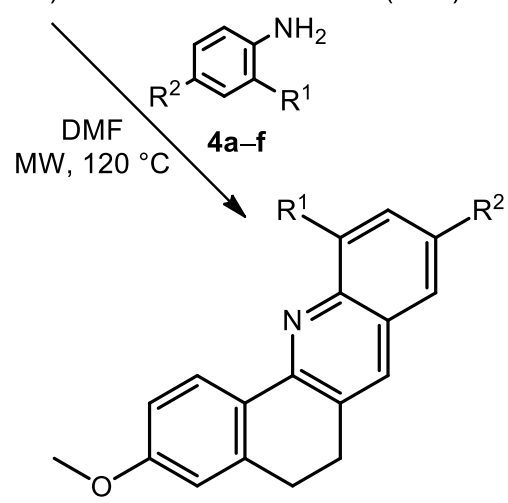

$9 a-f$

25. ábra: A 6-metoxi-tetralonhoz kondenzált kinolinszármazékok szintézise

A kiindulási vegyületből (6) Vilsmeier-Haack reakcióval, az ösztron-3-metil-éternél alkalmazott körülmények mellett, $\beta$-klórvinil-aldehid molekularészt tartalmazó vegyületet (7) ${ }^{113}$ szintetizáltunk, melyet a reakcióban képződő 4-klór-1,2-dihidro-7-metoxinaftalén mellékterméktől (8) ${ }^{114}$ elválasztottunk. A bifunkciós vegyületet anilinnel (4a) és szubsztituált anilinszármazékokkal (4b-f) reagáltattuk DMF-es közegben, mikrohullámú hőközlést alkalmazva. A 7-es vegyület reakciója az aromás aminokkal (4a-f) minden esetben stabilis termékeket $\left(\mathbf{9 a},{ }^{63} \mathbf{9 b}^{63}\right.$ és $\left.9 \mathbf{c}-\mathbf{f}\right)$ eredményezett a szubsztituens elektronigényétől és az aromás gyürün elfoglalt pozíciójától függetlenül. A kísérleti tapasztalatok azt mutatták, hogy a reakciók már $120{ }^{\circ} \mathrm{C}$-on lejátszódtak, ugyanakkor a 
reakciósebesség az aromás amin szubsztituensének függvényében változott. Elektronküldő csoportot tartalmazó reagensek $(\mathbf{4 b}, \mathbf{4 c})$ esetén a teljes konverzió eléréséhez 2 perces besugárzási idő is elegendő volt, szemben az anilinnél (4a) alkalmazott 5 perces melegítéssel. A kromatográfiás tisztítást követően mindhárom esetben jó hozamokkal (76-90\%) sikerült a kívánt termékeket (9a-c) kinyerni. A reakciót orto- $(\mathbf{4 d})$ valamint parahelyzetben (4e, 4f) elektronvonzó csoportot tartalmazó reagenssekkel elvégezve azt tapasztaltuk, hogy az első esetben a reakcióidő 20 percre növekedett, és a termékhozam 35\%-ra csökkent, mely az aromás gyürün található funkciós csoport sztérikus gátlásával volt értelmezhető. Az amin funkcióhoz képest távolabbi para-szubsztituensek esetén a teljes konverzióhoz 10 perc mikrohullámú besugárzásra volt szükség, melynek eredményeként a termékeket (9e-f) 54-62\%-os hozamokkal kaptuk.

A modellkísérletek során szerzett tapasztalatok alapján úgy döntöttünk, hogy a továbbiakban a kinolin heterogyürü kiépítését a szteránváz hattagú A-gyürüjén is elvégezzük (26. ábra). A bifunkciós szteroid szintéziséhez a Vilsmeier-Haack reakcióban 17ß-acetoxi5 $\alpha$-dihidrotesztoszteront (10) használtunk kiindulási anyagként. A korábbi reakciókörülményeket alkalmazva (26. ábra, $A$ módszer) azonban föként bisz-formilezett vegyület $(\mathbf{1 2})^{115}$ keletkezését tapasztaltuk a kívánt termék $(\mathbf{1 1})^{116}$ csekély mértékủ képződése mellett. A kísérletet rövidebb ideig, alacsonyabb hőmérsékleten elvégezve (26. ábra, $B$ módszer) a bisz-formileződés visszaszoríthatóvá vált, a bifunkciós molekularészt tartalmazó szteroidot (11) a tisztítást követően 78\%-os hozammal nyertük. Az előállított $\beta$-klórvinilaldehidet (11) ezután anilinnel (4a) és szubsztituált anilinszármazékokkal (4b-j) reagáltattuk a modellkísérlet körülményei mellett $\left(\mathrm{DMF}, \mathrm{MW}, 120^{\circ} \mathrm{C}\right)$. A reakciók során a 6-metoxi-tetralonból (6) képzett származékokhoz (9a-f) hasonlóan itt is markánsan megnyilvánult a reagens szubsztituensének elektronikus és sztérikus hatása a gyürüzárási folyamatokban (26. ábra). Elektronküldő funkciós csoportot tartalmazó reagensek esetén $(\mathbf{4 b}, \mathbf{4 c})$ a reakcióidő 2 percre csökkent, szemben az anilinnel végzett kísérletekkel (5 perc). Az elért termékhozamok ugyanakkor magasabbnak (91-92\%) bizonyultak, mint a szubsztituenst nem tartalmazó aromás amin (4a) használatakor (76\%). A meta-toluidinnel (4i) végzett reakció a lehetséges 2 régióizomer $(\mathbf{1 3 i}, \mathbf{1 3 i})$ keverékét eredményezte, jó összhozammal (90\%). A termékeket oszlopkromatográfiával nem tudtuk elválasztani, 3:1 termékarányukat ${ }^{1} \mathrm{H}$-NMR spektroszkópiás módszerrel határoztuk meg. Az aminocsoporttal szomszédos metil-szubsztituenst tartalmazó reagens (orto-toluidin, 4h) alkalmazásakor a termékhozam csökkent (73\%), mely a szubsztituens gyürüzárási folyamatra kifejtett sztérikus gátlásának tulajdonítható. 


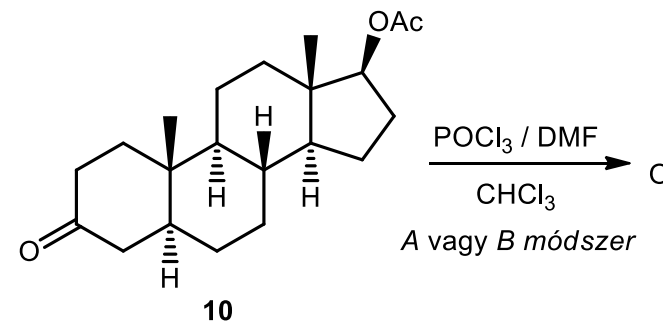

10

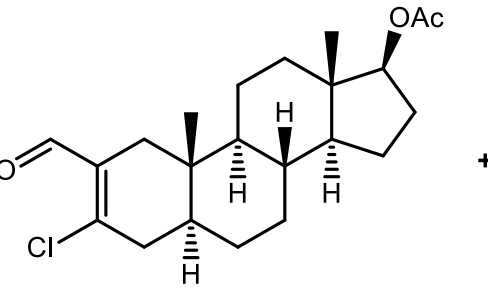

11 A módszer: $10 \%$ B módszer: $78 \%$<smiles>CC1(C)CC(C=O)=C(Cl)[C@@H](C=O)C1(C)C</smiles>

12 A módszer: $80 \%$

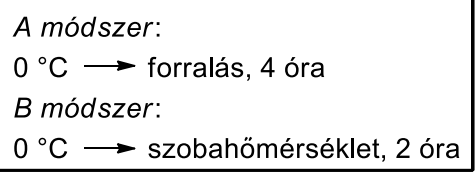<smiles>[R]c1ccc(N)c([R])c1CCCCC</smiles>

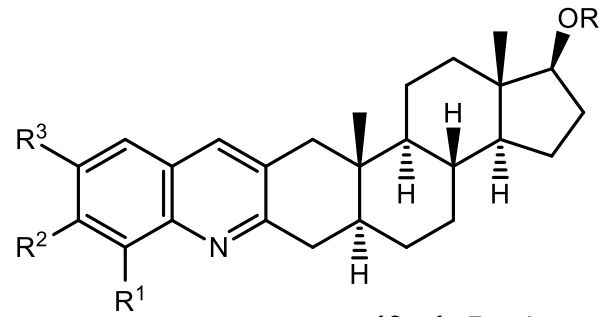
$\mathrm{KOH} / \mathrm{MeOH}$ 13a-i $R=A c$ $14 a-i \quad R=H$<smiles>C[N+](C)(C)O[Na]</smiles>

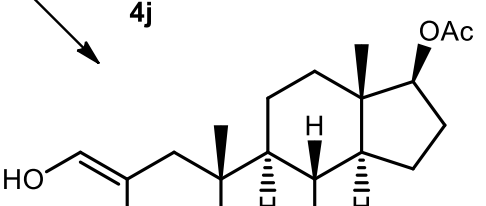<smiles>[IH2]</smiles>

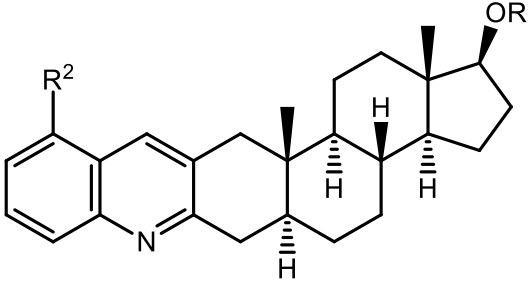
$\mathrm{KOH} / \mathrm{MeOH}$<smiles></smiles>

\begin{tabular}{|c|c|c|c|c|c|c|}
\hline $\begin{array}{c}\text { Aromás } \\
\text { amin }\end{array}$ & $\mathrm{R}^{1}$ & $\mathrm{R}^{2}$ & $\mathrm{R}^{3}$ & $\begin{array}{c}\text { Reakcióidö } \\
\text { (perc) }\end{array}$ & Termék(ek) & $\begin{array}{c}\text { Hozam* } \\
(\%)\end{array}$ \\
\hline $4 a$ & $\mathrm{H}$ & $\mathrm{H}$ & $\mathrm{H}$ & 5 & $13 a$ & 76 \\
\hline $4 b$ & $\mathrm{H}$ & $\mathrm{H}$ & $\mathrm{CH}_{3}$ & 2 & $13 b$ & 91 \\
\hline $4 c$ & $\mathrm{H}$ & $\mathrm{H}$ & $\mathrm{OMe}$ & 2 & $13 c$ & 92 \\
\hline $4 d$ & $\mathrm{Cl}$ & $\mathrm{H}$ & $\mathrm{H}$ & 20 & $13 d$ & 43 \\
\hline $4 e$ & $\mathrm{H}$ & $\mathrm{H}$ & $\mathrm{Cl}$ & 10 & $13 e$ & 59 \\
\hline $4 f$ & $\mathrm{H}$ & $\mathrm{H}$ & $\mathrm{Br}$ & 10 & $13 f$ & 60 \\
\hline $4 g$ & $\mathrm{H}$ & $\mathrm{Cl}$ & $\mathrm{H}$ & 10 & $13 g+13 g^{\prime}$ & $46+16$ \\
\hline $4 h$ & $\mathrm{CH}_{3}$ & $\mathrm{H}$ & $\mathrm{H}$ & 5 & $13 \mathrm{~h}$ & 73 \\
\hline $4 i$ & $\mathrm{H}$ & $\mathrm{CH}_{3}$ & $\mathrm{H}$ & 2 & $13 i+13 i^{\prime}$ & $90^{* *}$ \\
\hline
\end{tabular}

26. ábra: Androsztánváz A-gyürüjéhez kondenzált kinolinok szintézise

Elektronvonzó, para-helyzetű szubsztituenst tartalmazó anilinek esetén $(\mathbf{4 e}, \mathbf{4 f})$ a 10 percre növelt reakcióidő ellenére is csökkentek a termékhozamok (59-60\%). A kísérlet meta-klóranilinnel (4g) a meta-toluidinhez (4i) hasonlóan régióizomerek keverékét eredményezte, közepes összhozammal. A vegyületek ebben az esetben azonban oszlopkromatográfiával elválaszthatók voltak, a tisztítás utáni termékarányuk 13g:13g' = 3:1. A legnagyobb mértékủ reakciósebesség és termékhozam csökkenést (43\%) 
orto-klóranilin (4d) alkalmazásakor tapasztaltuk, mely a szubsztituens együttes kedvezőtlen elektronikus és sztérikus hatásával magyarázható.

A 27. ábrán szereplő ${ }^{1} \mathrm{H}-\mathrm{NMR}$ spektrumok bizonyítják a szteránváz 2,3-helyzetéhez kondenzált kinolingyürü kialakulását. A 13a spektrumán az aromás tartományban az öt új csúcs megjelenése mellett megfigyelhető a formil jel hiánya a kiindulási vegyülethez (11) képest. További megerősítést jelentenek a kondenzált heteroaromás gyürü jelenlétére az 1$\mathrm{H}_{2}$ és a 4- $\mathrm{H}_{2}$ protonok csúcsai, melyek a korábbi átfedő multiplett helyett magasabb kémiai eltolódásnál jelentkező diszkrét jelekként azonosíthatók.

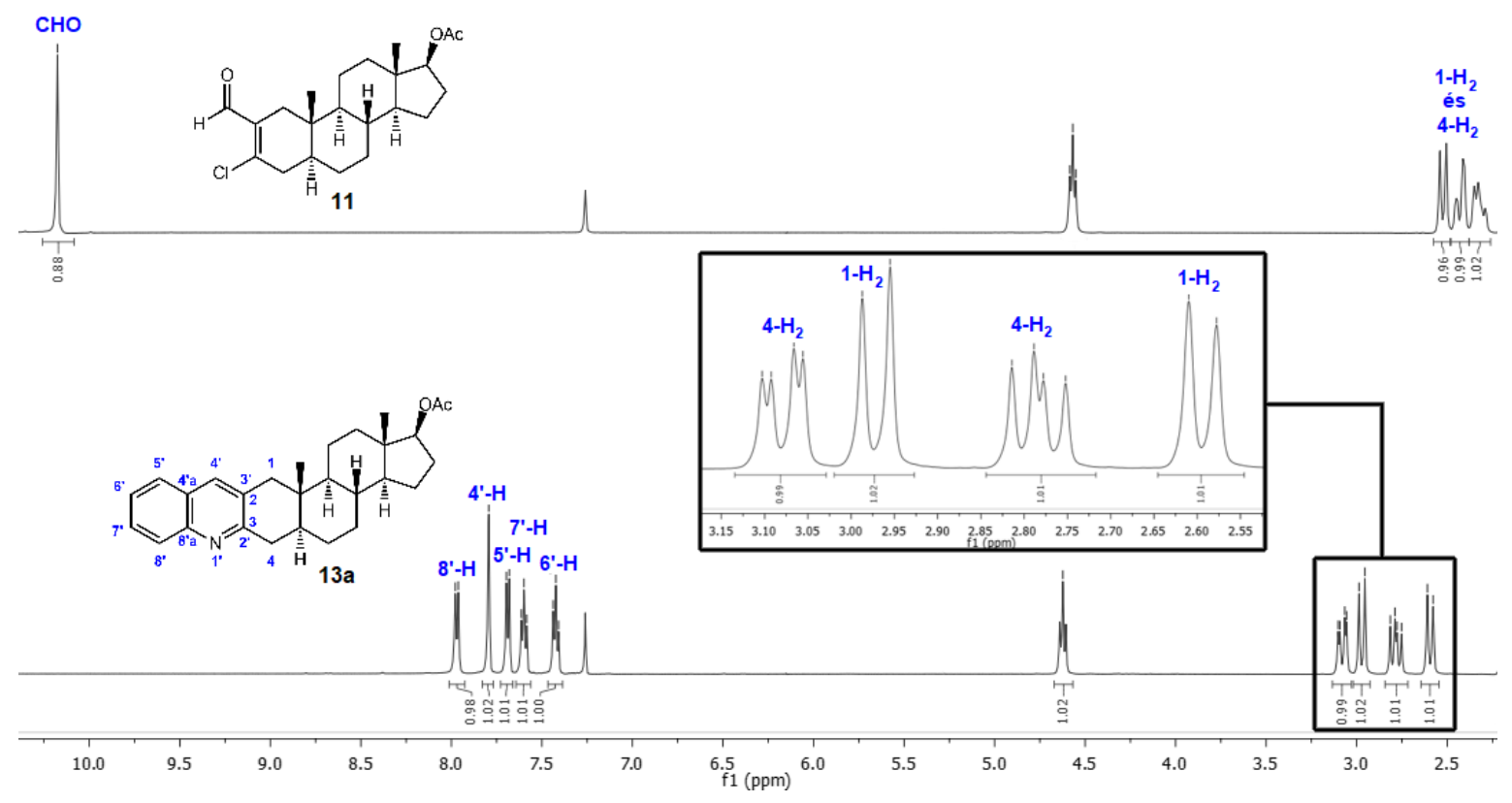

27. ábra: A kiindulási $\beta$-klórvinil-aldehid (11) és az anilinnel képzett származék (13a) ${ }^{1} \mathrm{H}-\mathrm{NMR}$ spektrumainak részlete

A heterociklizáció egy esetben nem volt sikeres. A erősen elektronvonzó csoportot tartalmazó 4-nitroanilin (4j) és a bifunkciós szteroid (11) reakciójában a megnövelt reakcióidő vagy hőmérséklet ellenére sem sikerült kondenzált kinolinszármazékot előállítani (26. ábra). A keletkező $\beta$-arilaminovinil-aldehid származék (15) imino-enol (26. ábra) szerkezetét a ${ }^{1} \mathrm{H}-\mathrm{NMR}$ spektroszkópiával igazoltuk. A tiszta formában izolált kondenzált heterociklusos termékek (13a-h, 13g') lúgos közegü dezacetilezésével $(\mathrm{KOH} / \mathrm{MeOH})$ 17ß-OH származékokat (14a-h, 14g') nyertünk (26. ábra).

A kísérleti tapasztalatok alapján javaslatot tettünk a reakció mechanizmusára vonatkozóan (28. ábra). A $\beta$-klórvinil aldehidek $(2,7,11)$ reakciói anilinnel (vagy 
származékaival) (4) minden esetben 2,3-diszubsztituált kinolinokat $(\mathbf{5}, \quad \mathbf{9}, \mathbf{1 3})$ eredményeznek, a másik lehetséges 3,4-diszubsztituált régióizomer (28. ábra, D) keletkezése nélkül, függetlenül az alkalmazott reakciókörülményektől. ${ }^{62,117}$ Így, korábban az 1 ekvivalens anilinnel végzett kísérletek során azt feltételezték, hogy a reakció első lépésében keletkező1-klórvinil( $N$-aril)imin (28. ábra, A) egy bonyolult, többlépéses, tetrahidropirimidin gyürüs intermediert tartalmazó intermolekuláris gyürüzáráson keresztül eredményezi a 2,3-diszubsztituált kinolinokat. ${ }^{112}$
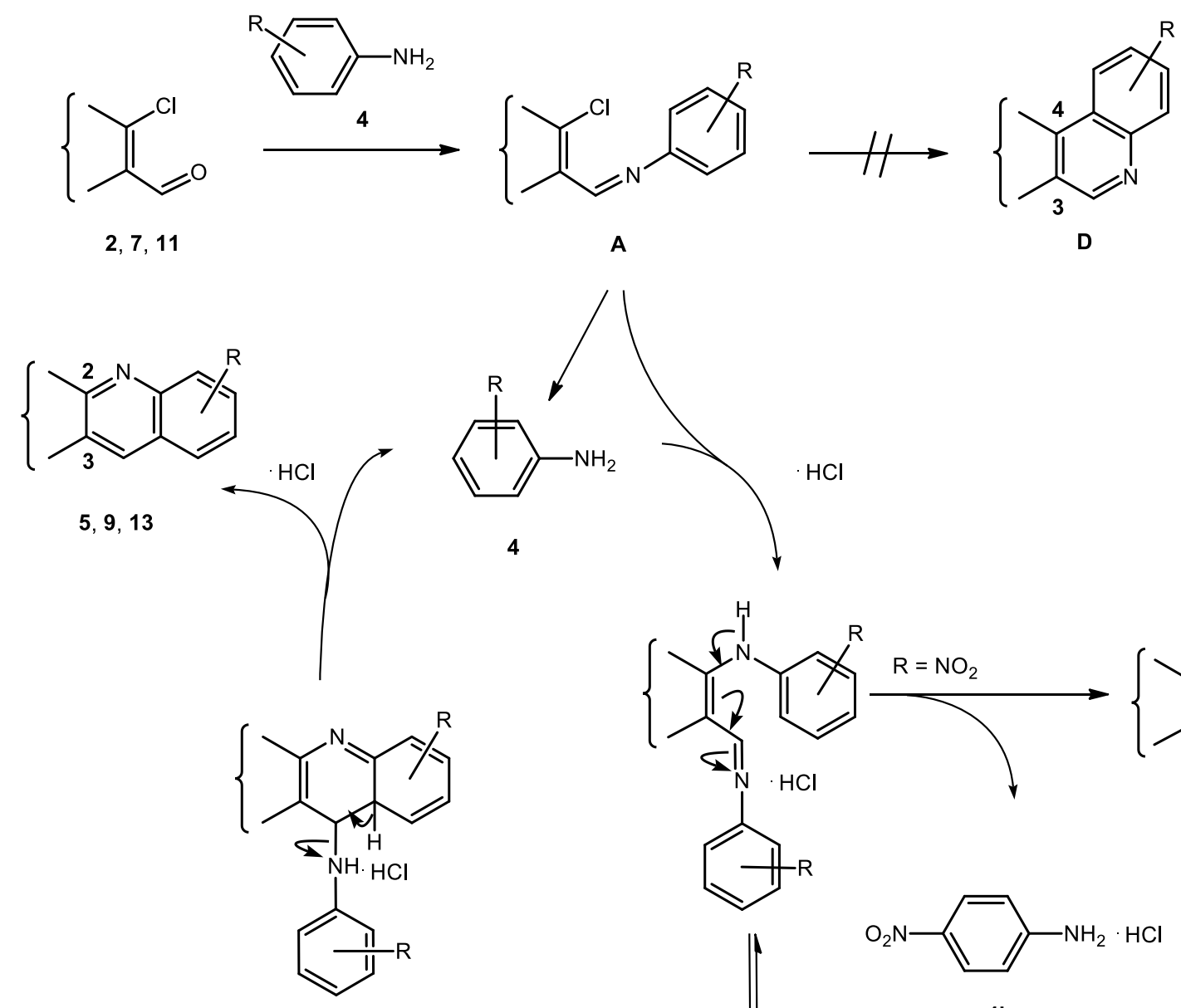

C
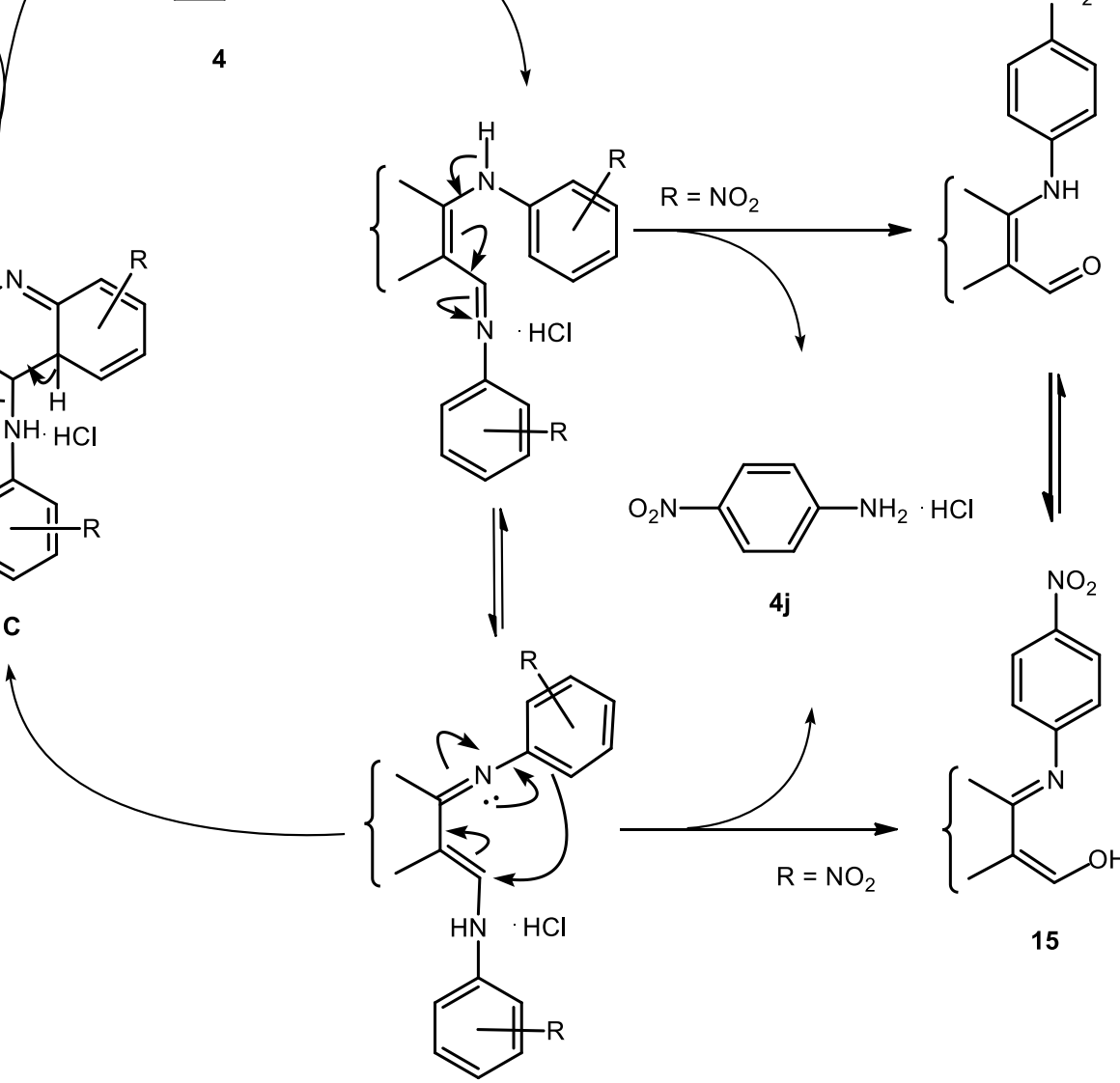

B

28. ábra: A gyürúzárási folyamat javasolt mechanizmusa 
Sokkal valószínübb azonban, hogy az A vegyület a DMF-ben jelenlévő víztartalom hatására kis mértékben bomlik és a felszabaduló anilin (4) a maradék iminnel (A) elreagálva $N$-arilénamino-imin-hidroklorid köztiterméket $(\mathbf{B})$ eredményez. ${ }^{62} \mathrm{Ez}$ utóbbi $\mathbf{C}$ intermedieren keresztül lejátszódó gyürüzárása a heterociklusos származékhoz (5, 9 vagy $\mathbf{1 3})$ vezet, az aromás gyürün lévő szubsztituens helyezetétől és elektronikus karakterétől függő hozammal. Az elektronküldő csoportot tartalmazó reagensek kedvezőek a gyürüzárási folyamatra nézve, míg az elektronvonzó funkciót magukon hordozó vegyületek kedvezőtlenek. A para-helyzetben erősen elektronvonzó nitrocsoportot tartalmazó aromás amin (4j) meggátolja a gyürüzárási lépést, és a $\mathbf{B}$ intermedier $N$-aril-aminovinil-aldehiddé bomlik, mely a tautomériára való hajlama miatt a stabilisabb imino-enol formájává (15) alakul át. ${ }^{117}$ Orto-helyzetű szubsztituenst tartalmazó reagensek esetében a funkciós csoport, valamint a szteránváz egyes szerkezeti elemei (13-as helyzetü anguláris metilcsoport) sztérikusan gátolhatják a gyürüzárási folyamatot.

Mindezek alapján megállapítottuk, hogy a szteránváz D- és A-gyürüjéhez kondenzált kinolinszármazékok előállítása során jelentős reaktivitásbeli különbség van a váz két gyürüje között. Továbbá sikerült következtetéseket levonni a szubsztituált anilinszármazékok funkciós csoportjainak a gyürüzárási folyamatra gyakorolt sztérikus és elektronikus hatásairól. A kísérleti tapasztalatok alapján javaslatot tettünk a reakció mechanizmusára. Az egyes vegyületek szerkezetét ${ }^{1} \mathrm{H}$ - és ${ }^{13} \mathrm{C}-\mathrm{NMR}$, továbbá tömegspektrometriai mérésekkel igazoltuk.

Az összes általunk tiszta formában izolált származékot (5a-c, 9a-f, 13a-h, 13g', 14a-h, 14g') együttmüködés keretében in vitro farmakológiai vizsgálatok alá vetették, melyek eredményei az 5. fejezetben kerülnek bemutatásra. 


\subsection{Androsztánvázhoz kondenzált pirazolok szintézise 118}

Kísérleti munkánk további részében a szteránváz A- és D-gyürüjéhez kondenzált pirazolok szintézisét végeztük el. Utóbbi származékok kiindulási anyagaként a 16-hidroximetiléndehidroepiandroszteront (formil-DEA) (17) választottuk, melyet dehidroepiandroszteron3 $\beta$-acetátból (16), az irodalomból már ismert Claisen-kondenzációs módszerrel állítottunk elő (29. ábra). ${ }^{119}$ Elméletileg a 17-es származéknak 3 tautomer formája (29. ábra, 17-A, 17-B, 17-C) létezik, melyek egyensúlyát nagymértékben befolyásolja az oldószer protikus jellege, polaritása és a közeg savassága, valamint hatással lehetnek rá sztérikus faktorok is. A szakirodalom alapján a szerves oldószerekben a 17-B és a 17-C formák dominálnak, ${ }^{120}$ azonban a pH csökkenése vagy az oldószer polaritásának növelése az egyensúlyt a 17-A forma felé tolja el.

A szintézis paramétereinek optimalizálása érdekében a kiindulási bifunkciós 1,3-dikarbonil vegyületet (17) elöször a Knorr-reakció klasszikus körülményei között etanolos közegben fenilhidrazinnal (18a) reagáltattuk, katalitikus mennyiségü ecetsav jelenlétében (29. ábra, $B$ módszer), illetve hiányában (29. ábra, $A$ módszer). Az utóbbi esetben a reakció a forralás ellenére is lassabban (1 óra) játszódott le, mint a szobahőmérsékletü katalitikus átalakítás $(30$ perc $)$. A szakirodalomban leírtakkal összhangban ${ }^{90}$ mindkét reakció során a 19a termék régiószelektív keletkezését tapasztaltuk. Mivel a körülmények optimalizálásának egyik célja az volt, hogy a reakciót a későbbiekben a kereskedelmi forgalomban hidroklorid sóként kapható szubsztituált fenilhidrazin származékokra is kiterjesszük, a szintézist elvégeztük fenilhidrazin-hidrokloriddal $(\mathbf{1 8 a} \cdot \mathrm{HCl})$ is, a reagenssel ekvivalens mennyiségű $(1,1$ ekv.) $\mathrm{KOH}$ jelenlétében, etanolos forralás mellett (29. ábra, $C$ módszer). A gyürüzárás ezúttal is régiószelektíven a 19a termék képződéséhez vezetett. Figyelembe véve, hogy a kiindulási anyag (17) tautomer egyensúlya a közeg pH-jának változtatásával eltolható, a kísérletet megismételtük a $\mathrm{KOH}$ helyett 0,3 ekvivalens mennyiségü $p$-TsOH hozzáadásával is (29. ábra, $D$ módszer). A ciklokondenzáció etanolos forralás mellett 10 perc alatt lejátszódott a lehetséges régióizomerek (19a és 20a) 1:1 arányú keverékét eredményezve. Mivel a fenilhidrazinhidroklorid $(\mathbf{1 8 a} \cdot \mathbf{H C l})$ sójából való felszabadításához a szakirodalomban bázis $(\mathrm{KOH}$, $\mathrm{NaOAc}, \mathrm{K}_{2} \mathrm{CO}_{3}$ vagy $\mathrm{Et}_{3} \mathrm{~N}$ ) alkalmazására többnyire csak etanolos közegben van példa, a 
reakciót elvégeztük piridinben is, mely egyszerre szolgált a szintézis során bázisként és oldószerként (29. ábra, E módszer).

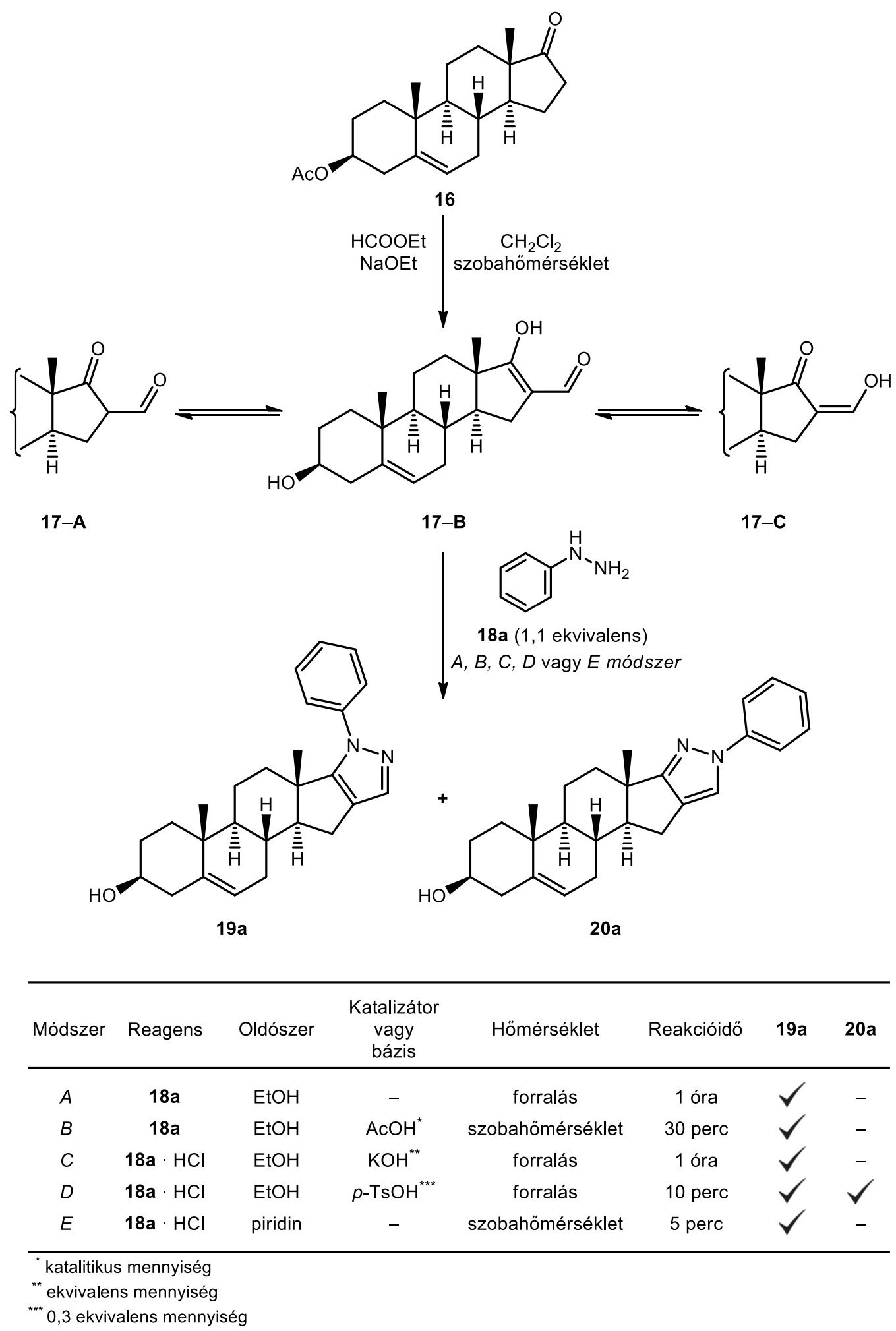

29. ábra: A dehidroepiandroszteron-3ß-acetátból (16) előállított D-gyürühöz kondenzált pirazolok (19a és 20a) szintézise és az alkalmazott reakciókörülmények 
A VRK-s ellenőrzés alapján ez utóbbi átalakulás szobahőmérsékleten szinte pillanatszerủen játszódott le, és kizárólagosan a 19a termék régiószelektív keletkezését eredményezte.

A 19a izomer gyorsabb képződése és ezáltal a régiószelektivitás a fenilhidrazinnak (18a) a kiindulási vegyület (17) elektrofilebb aldehid szénatomjára való támadásával értelmezhető (30. ábra). A szelektív termékképződés ugyancsak magyarázható a megfelelő fenilhidrazon köztitermék képződésekor a 17-es ketocsoporthoz képest $\alpha$-helyzetü szénatomon jelenlévő anguláris metilcsoport által okozott sztérikus zsúfoltsággal. ${ }^{83}$ Ezenkívül a végső sebességmeghatározó dehidratációs lépés (5-hidroxipirazolinből pirazol) egy tercier alkohol esetén gyorsabb, mint egy szekunder alkoholnál (30. ábra). Mindkét régióizomer (19a és 20a) keletkezése erősen savas közegben annak tulajdonítható, hogy a pH csökkenése befolyásolja a folyamat sebességmeghatározó lépését. ${ }^{83} \mathrm{~A}$ sav jelenléte gyorsíthatja a reakciót azáltal, hogy a köztitermékek OH-csoportjainak protonálásával elősegíti a víz kilépését az intermedierekből.

Az oszlopkromatográfiával keverékfrakció nélkül elválasztott termékeket (19a, 20a) NMR spektroszkópiával vizsgáltuk. A 19a és 20a származékok esetében, ahol a nitrogénhez közvetlenül fenilcsoport kapcsolódik, a ${ }^{1} \mathrm{H}-\mathrm{NMR}$ spektrumokon 7,18 és 7,62 ppm kémiai eltolódás között megjelentek az aromás gyürü jellegzetes multiplettjei. Ebben a tartományban ugyancsak megfigyelhető a 19a vegyület heterogyürüjén lévő 3 '-H szingulettje 7,39 ppm-nél, valamint a 20a származék pirazolgyürüjén lévő 5'-H szingulett jele 7,51 ppm-nél. A két izomert (19a és 20a) a ${ }^{1} \mathrm{H}-\mathrm{NMR}$ spektrumaik alapján nem tudtuk megkülönböztetni, de a 17-C atomjaik, valamint a 3'-C (19a) és az 5'-C (20a) atomok eltérö kémiai eltolódásainak összehasonlítása erre lehetőséget adott. Az irodalomban megtalálható szteránvázas $\beta$-ketoaldehidek hidrazinnal történő gyürüzárásával, majd a heterogyürü alkilszulfonilezésével $^{121}$ vagy alkilezésével ${ }^{122}$ indirekt módon korábban nyert A- és Dgyürühöz kondenzált pirazol régióizomerek spektrális adatai alapján a származékok azonosítása sikerrel járt. A piridinszerü környezetben lévő szénatom $(C=N)$ nagyobb kémiai eltolódásnál ad jelet, mint a pirrolszerü környezetben lévő $(\mathrm{N}-\mathrm{C}=)$, így a 17-es és a pirazol gyürüben lévő $3^{\prime}$ vagy $5^{\prime}$ szénatom jelei alapján lehetőség volt az izomerek szerkezetigazolására. A 20a vegyület 17-C jele 170,8 ppm-nél míg a 19a vegyületé 157,2 ppm-nél jelentkezik. Ugyanez a tendencia figyelhető meg a 3'-C és az 5'-C csúcsoknál is, ahol az előbbi a 19a esetében 135 ppm-nél, míg az utóbbi a 20a vegyületnél 121,0 ppm-nél található a ${ }^{13} \mathrm{C}-\mathrm{NMR}$ spektrumokon. 


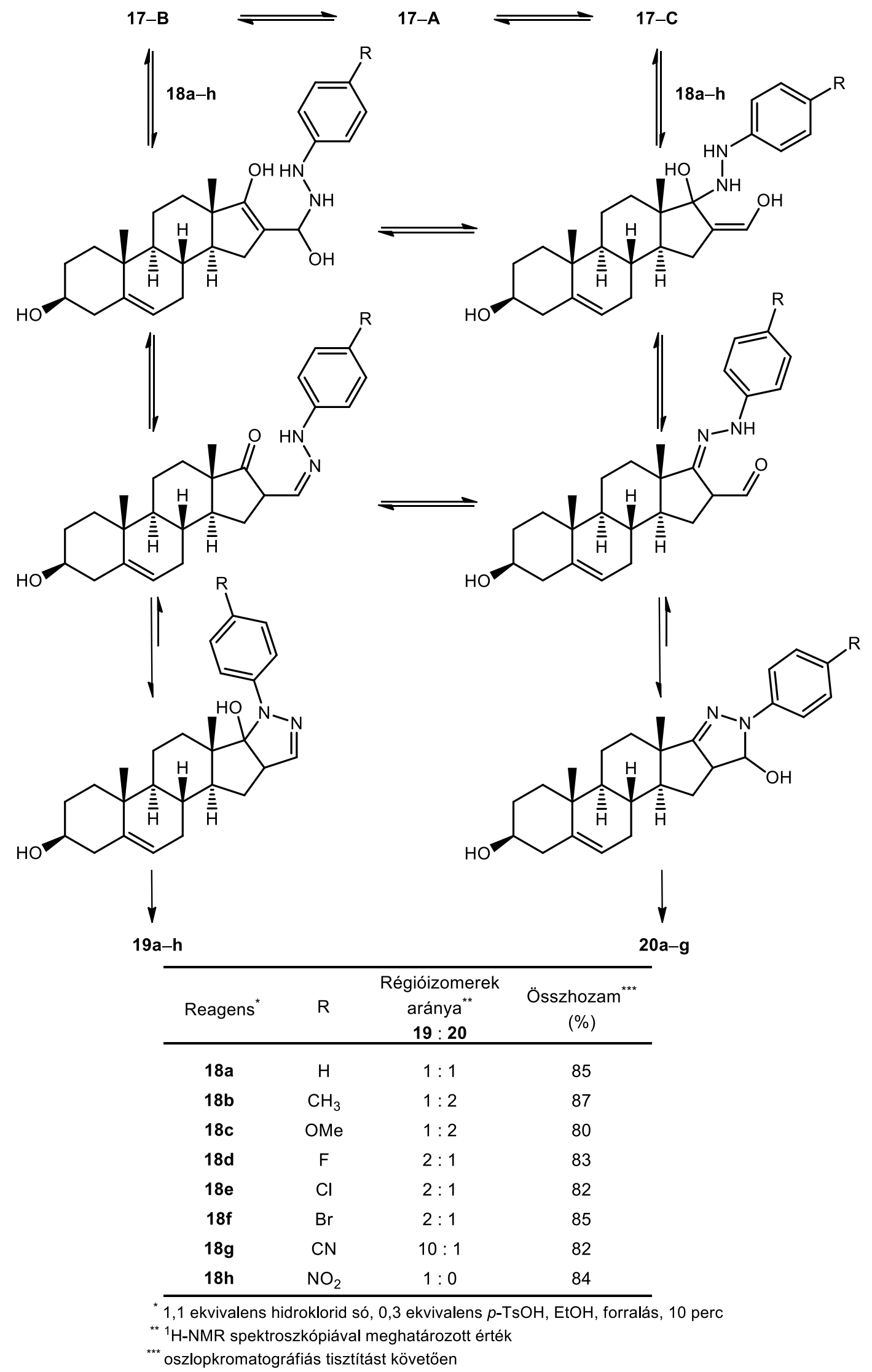

30. ábra: A formil-DEA (17) és az arilhidrazinok (18a-h) között végbemenő reakció javasolt mechanizmusa 
Az azonosítást segítette a Kutatócsoportban korábban egy telítetlen oldalláncú D-szeko-aldehid arilhidrazonjának intramolekuláris 1,3-dipoláris cikloaddíciójával előállított szteránvázas vegyület is, ${ }^{29}$ mely az általunk szintetizált 20c-vel szerkezeti analógiát mutatott. A 31. ábrán a régióizomerek megkülönböztetésére szolgáló karakterisztikus ${ }^{1} \mathrm{H}$ - és ${ }^{13} \mathrm{C}$-NMR eltolódási értékek láthatók.

$\begin{array}{llccccc} & & & \\ \end{array}$

31. ábra: A D-gyürühöz kondenzált pirazol régióizomerek szerkezete és az azonosításukhoz használt NMR eltolódás értékek

A továbbiakban a kiindulási bifunkciós szteroid (17) és helyettesített fenilhidrazinhidroklorid sók (18b-h) reakcióit végeztük el mind savas etanolos, mind piridines közegben a szubsztituensek termékeloszlásra gyakorolt esetleges hatásának feltérképezése érdekében. A piridinben végzett kísérletek során minden esetben régiószelektíven egy termék $(\mathbf{1 9 b}-\mathbf{h})$ képződését tapasztaltuk, azonban etanolos közegben, $p$-TsOH hozzáadása mellett, a 4-nitro-fenilhidrazin (18h) kivételével a két lehetséges régióizomer (19a-g, 20a-g) 
keverékét kaptuk (30. ábra). Az erősen elektronvonzó nitrocsoportot tartalmazó reagens (18h) esetén a szelektivitás azzal magyarázható, hogy a szubsztituens hatására a hidrazinszármazék terminális nitrogénjének elektronsürüsége és ezáltal nukleofilitása lecsökken, így csak a kiindulási anyag 17-B tautomerjének 16-os helyzetü formilcsoportjával képes reakcióba lépni. Más, elektronvonzó szubsztituenst tartalmazó reagensek (18d-g) alkalmazása is a $\mathbf{1 9}$-es régióizomer felé tolta el a termékarányt. Elektronküldő funkciós csoportot tartalmazó arilhidrazinok (18b, 18c) használatakor ugyanakkor a 20-as izomer nagyobb mennyiségű keletkezése volt tapasztalható. Az utóbbi kísérleti megfigyelés azzal értelmezhető, hogy a reagens a terminális nitrogénjén megnövekedett elektronsürüség hatására a kiindulási vegyület mindkét funkciós csoportjával (16-formil, 17-keto) képes elreagálni, és a második intramolekuláris nukleofil addíciós lépés az aldehid szénatomon gyorsabb.

A régióizomer párok (19a-g és $\mathbf{2 0 a}-\mathbf{g})$ oszlopkromatográfiás elválasztását követően a kapott termékarányok jól korreláltak az ${ }^{1} \mathrm{H}-\mathrm{NMR}$ spektroszkópiával meghatározott értékekkel. A tisztán kinyert anyagok szerkezetét ${ }^{1} \mathrm{H}$ - és ${ }^{13} \mathrm{C}-\mathrm{NMR}$ spektroszkópiával igazoltuk. A heterogyürü nitrogénatomjaihoz kapcsolódó szénatomok kémiai eltolódás értékeinél a következő relációk érvényesültek: $\delta\left(\mathrm{C}-3^{\prime}\right) 19>\delta\left(\mathrm{C}-5^{\prime}\right) 20$ és $\delta(\mathrm{C}-17) 20>\delta(\mathrm{C}-17) 19$. A 20-as izomer 5'-H protonjának kisebb árnyékoltsága, ezáltal magasabb kémiai eltolódása (a 19-es izomer 3'-H protonjához képest), ugyanakkor a szomszédos nitrogénatomhoz kapcsolódó aromás gyürü mágneses anizotrópiájának tulajdonítható. ${ }^{123}$

A szteránváz A-gyürüjéhez kondenzált hasonló származékok szintéziséhez kiindulási anyagként a 2-hidroximetilén-5 $\alpha$-dihidrotesztoszteront (21) ${ }^{124}$ választottuk, melyet 17ß-acetoxi-5 $\alpha$-dihidrotesztoszteronból (10) Claisen-kondenzációval nyertünk (32. ábra). ${ }^{119} \mathrm{~A}$ kiindulási $\beta$-ketoaldehid a D-gyürüs származékhoz (17) hasonlóan 3 tautomer formájának keverékeként van jelen oldat fázisban, melyet a VRK-ellenőrzésnél meg is figyeltünk. A származék a ${ }^{1} \mathrm{H}-\mathrm{NMR}$ spektruma alapján döntően a 21-B és a 21-C formáiban van jelen deuterált kloroformban $\left(\mathrm{CDCl}_{3}\right)$.

Első lépésben a szteránvázas 1,3-dikarbonil vegyületet (21) fenilhidrazinnal (18a) reagáltattuk etanolos közegben (32. ábra, $A$ módszer). A kiindulási anyag rossz oldhatósága miatt a reakció teljes lejátszódásához 30 perces forralásra volt szükség. 


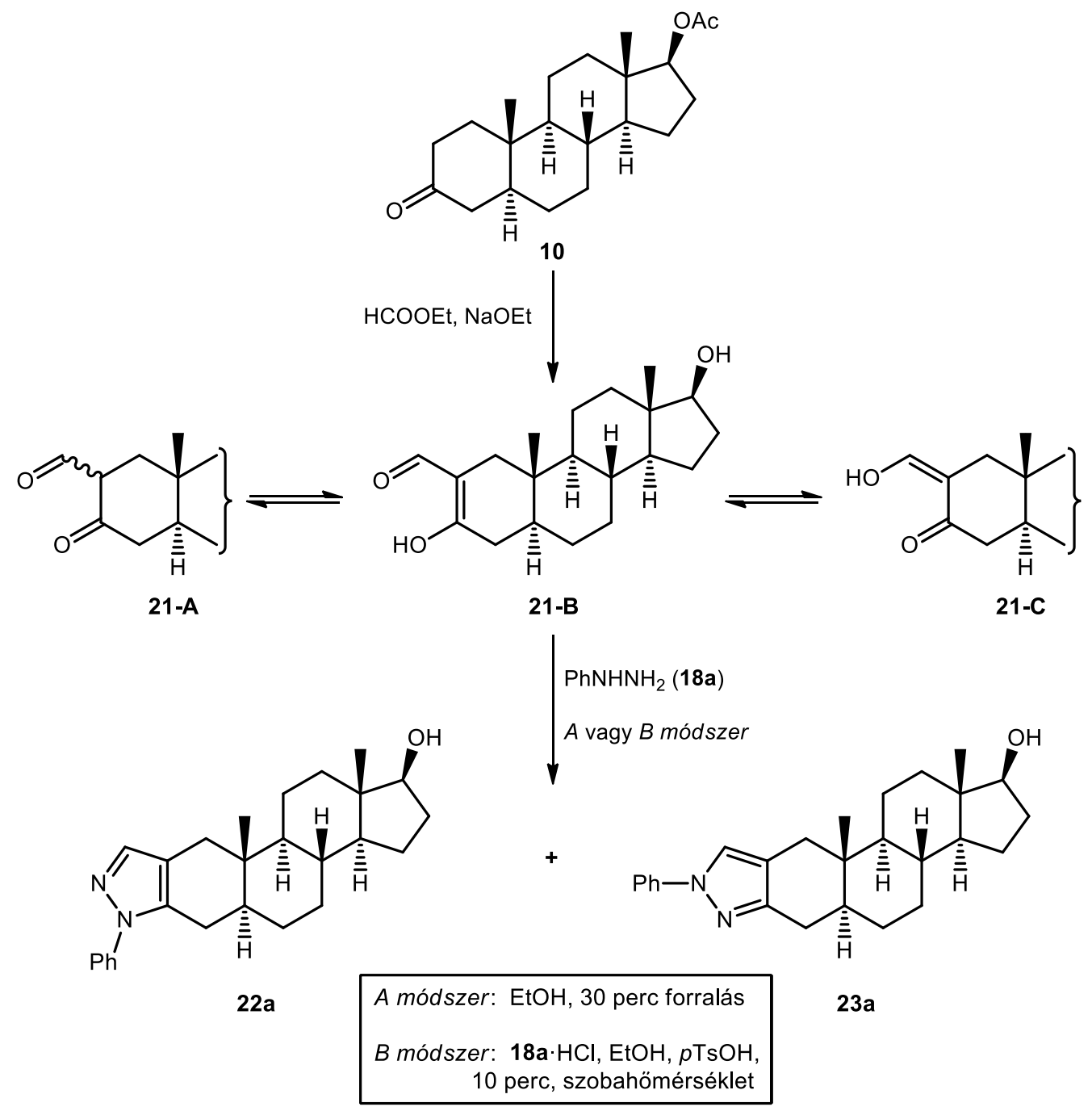

32. ábra: Androsztánváz A-gyürüjéhez kondenzált fenil-szubsztituált pirazol régióizomerek előállítása

A kísérlet során a 21-es vegyület bifunkciós hattagú A-gyürüje nagyobb reaktivitást mutatott, mint a 17-es származék öttagú D-gyürüje. A szakirodalomban megtalálható hasonló pirazolképzés ${ }^{125}$ régiószelektív jellegével (22a-nak megfelelő termék) ellentétben a reakció esetünkben a két lehetséges régióizomer (22a és 23a) 4:3 arányú keverékéhez vezetett, 90\%-os összhozammal. Ez a megfigyelés arra enged következtetni, hogy a Dgyürüs vegyületnél (17) semleges etanolos közegben a közeli 18-as anguláris metilcsoport jelentősen hozzájárul a szelektív termékképződéshez. Ezzel szemben a ciklokondenzációt a 21-es származéknál nem gátolja nagy térkitöltésü szubsztituens sem az aldehid-, sem a ketofunkciós csoport szomszédságában, így mindkét lehetséges izomer (22a és 23a) keletkezése megfigyelhető. A reakciót etanolban fenilhidrazin-hidrokloriddal $(\mathbf{1 8 a} \cdot \mathrm{HCl}) 0,3$ ekvivalens $p$-TsOH jelenlétében (32. ábra, $B$ módszer) megismételve a kiindulási bifunkciós szteroid 
(21) azonnal feloldódott, és a folyamat szobahőmérsékleten mindössze 10 perc alatt teljesen lejátszódott, 1:1 arányú termékkeveréket (22a és 23a) eredményezve.

A szintézist piridinben elvégezve ugyanakkor a VRK-ellenörzés szerint 5 perc után teljes volt a konverzió, és a savmentes etanolban végzett kísérlettel azonos 4:3 arányú termékkeverék képződött (33. ábra). A reakciókat ezután szubsztituált arilhidrazinhidrokloridokkal $(\mathbf{1 8 b}-\mathbf{h} \cdot \mathrm{HCl})$ is elvégeztük piridines közegben. Az átalakítások minden esetben régióizomer párokat (22b-h, 23b-h) eredményeztek jó összhozamokkal (33. ábra). A termékarányokat ${ }^{1} \mathrm{H}-\mathrm{NMR}$ spektroszkópiával határoztuk meg. Erősen elektronvonzó szubsztituenst $\left(\mathrm{CN}, \mathrm{NO}_{2}\right)$ tartalmazó reagensek $(\mathbf{1 8 g}, \mathbf{1 8 h})$ esetén az arány a $\mathbf{2 3}$-as izomer felé tolódott el, míg az elektronküldő $\left(\mathrm{CH}_{3}, \mathrm{OMe}\right)$ funkciós csoportokat tartalmazó (18b, 18c), illetve a halogéntartalmú ( $\mathrm{F}, \mathrm{Cl}, \mathrm{Br})$ fenilhidrazin származékok (18d-f) nem gyakoroltak jelentős hatást a keletkező termékek eloszlására a fenilhidrazinnal (18a) végzett kísérlethez képest. Ha a reakció a szteránváz A-gyürüjén is hidrazon intermedieren keresztül játszódna le, mint a D-gyürüs származékok esetében (30. ábra), vagy a Kutatócsoportban Iványi és munkatársai által korábban szintetizált 17-exo-pirazoloknál, ${ }^{87,88}$ akkor fordított termékarány keletkezését kellett volna tapasztalnunk az elektronvonzó funkciós csoportok esetén. Az általunk megfigyelt szubsztituenshatás azonban nem példa nélküli. Hasonló jelenséget figyeltek meg korábban a $\beta$-ketoaldehidekhez hasonló reaktivitású alkiltrifluormetil-1,3-diketonok fenilhidrazinnal és 2,4-dinitro-fenilhidrazinnal való reakciója során, melyet a két egyensúlyban lévő 3,5-dihidroxi-pirazolidin köztitermék eltérő dehidratációs sebességével magyaráztak. ${ }^{81}$ Mivel az arilhidrazinok terminális nitrogénjének a közbülsőnél nagyobb a nukleofilitása, ${ }^{84}$ gyengén bázikus körülmények között a 33. ábrán szereplő reakciómechanizmus feltételezhető. A 21-es bifunkciós vegyület és a 2,4-dinitrofenilhidrazin reakcióját elvégezve heterociklus kialakulását nem tapasztaltuk, a folyamatban a megfelelő hidrazon csekély mértékű keletkezése mellett számos nem azonosított melléktermék keverékét kaptuk. Ez a megfigyelés bázikus közegben egy elég összetett reakciómechanizmus feltételezésére utal. 


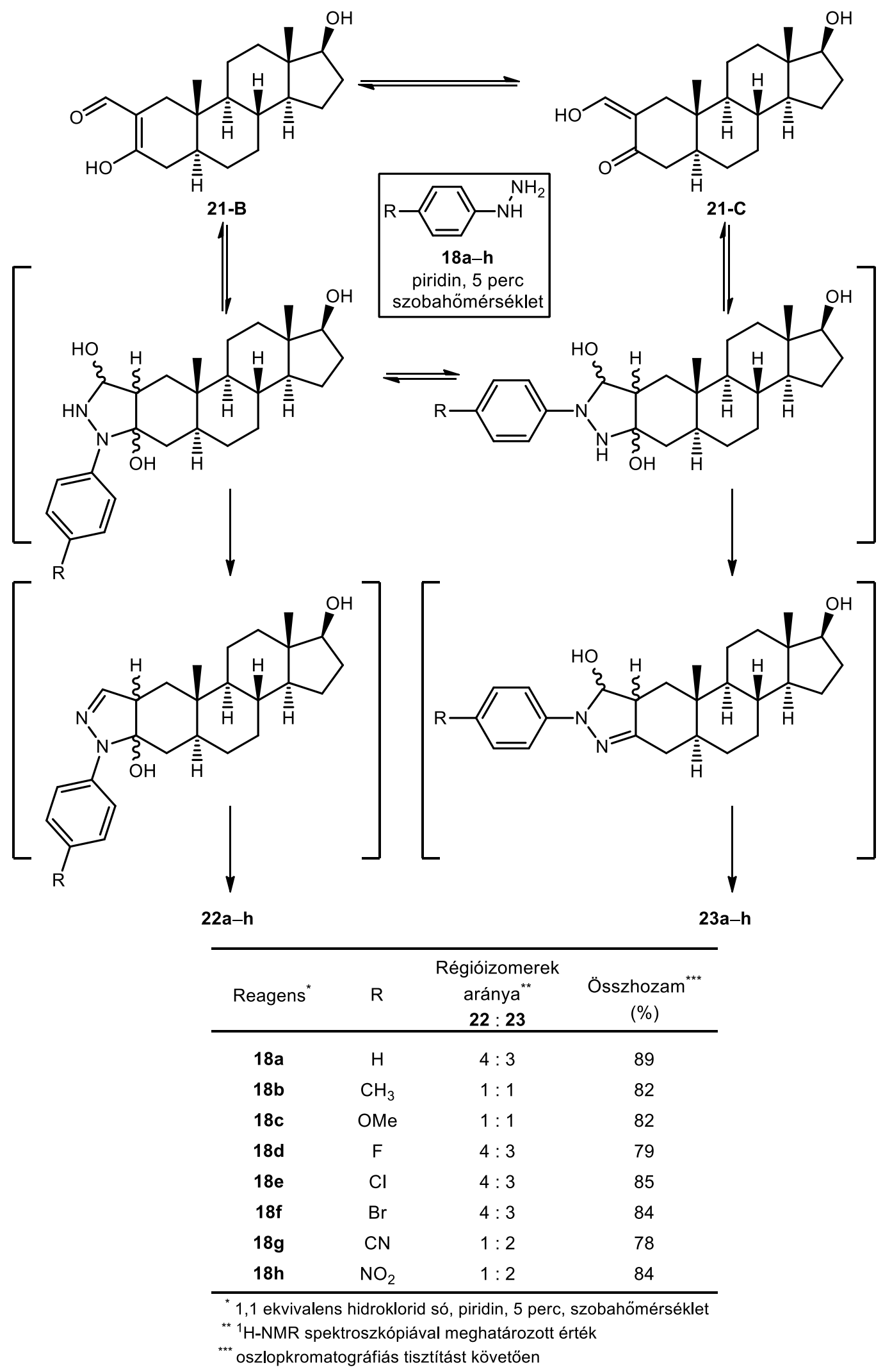

33. ábra: 5 $\alpha$-Androsztánváz A-gyürüjéhez kondenzált pirazolok szintézise piridines közegben 
A kapott régióizomereket $(\mathbf{2 2 a}-\mathbf{h}, \mathbf{2 3 a}-\mathbf{h}){ }^{1} \mathrm{H}$ - és ${ }^{13} \mathrm{C}-\mathrm{NMR}$ spektrumaik alapján azonosítottuk (34. ábra). A karakterisztikus kémiai eltolódás értékek hasonló tendenciát mutattak, mint a D-gyürühöz kondenzált származékok (19a-h, 20a-g) esetén.

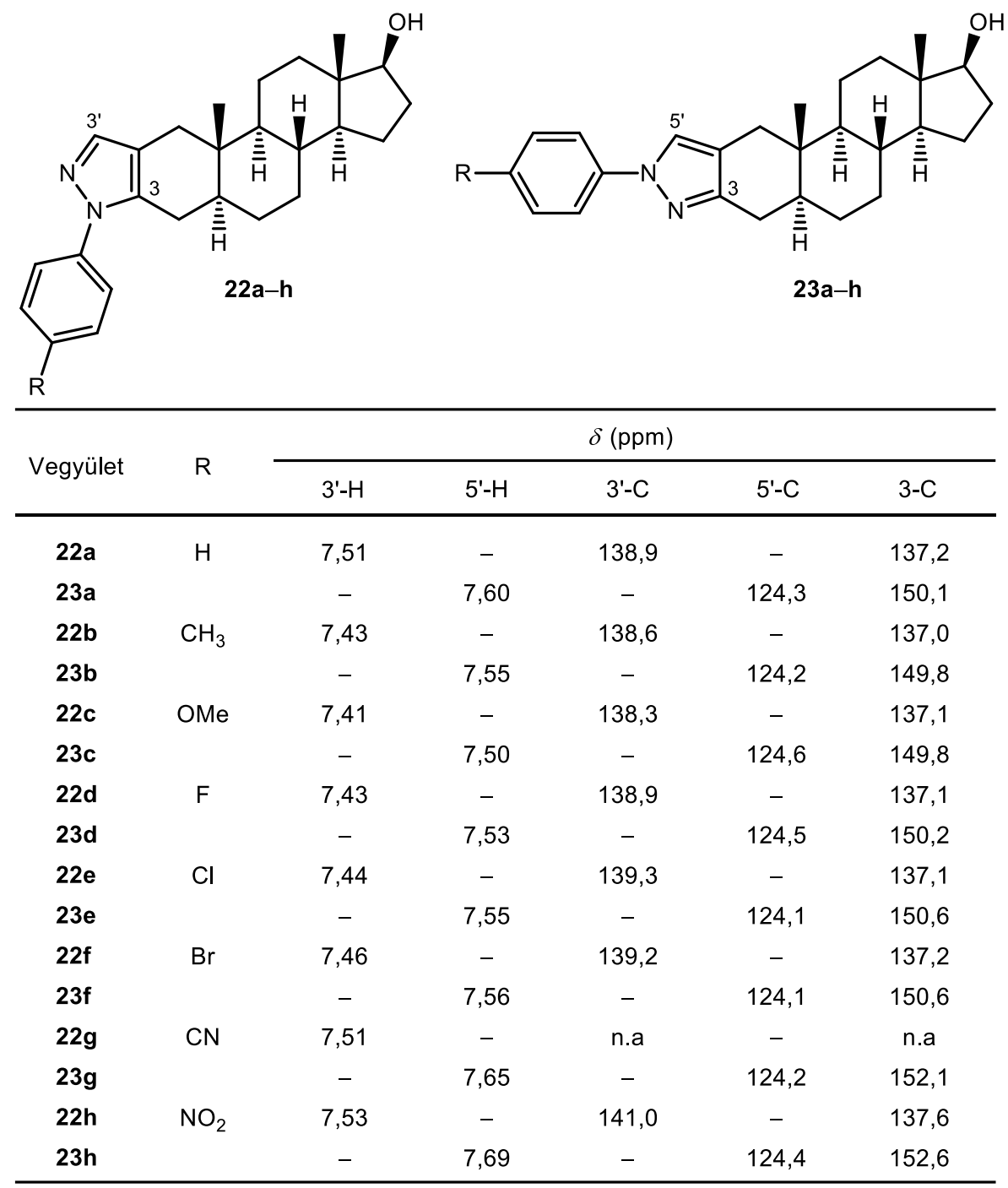

34. ábra: Az A-gyürühöz kondenzált pirazol régióizomerek szerkezete és az azonosításukhoz használt NMR eltolódás értékek

Az összes elöállított szteránvázhoz kondenzált pirazol (19a-h, 20a-g, 22a-h, 23a-h) a kinolinszármazékokhoz hasonlóan in vitro farmakológiai vizsgálatra került együttmüködés keretében. A hatástani vizsgálatok eredményeit az 5. fejezet tartalmazza. 


\subsection{Szteránvázhoz kondenzált pirimidinszármazékok előállítása multikomponensü reakciókkal ${ }^{126}$}

A kísérleti munka befejező részében androsztánvázhoz kondenzált pirimidinszármazékok szintézisét valósítottuk meg multikomponensü reakciókkal. Első lépésben az irodalmi előzményekben ismertetett, Barthakur és munkatársai által a kolesztánváz A-gyürüjén kidolgozott reakciókörülmények ${ }^{102}$ alkalmazásával kíséreltük meg a szteránváz D-gyürüjéhez kondenzált hattagú heterociklus kialakítását. A kiindulási anyagként választott 16-hidroximetilén-dehidroepiandroszteront (17) 2 ekvivalens benzaldehiddel (24a) vagy $p$-klór-benzaldehiddel (24b) és 2 ekvivalens ammónium-acetáttal reagáltattuk oldószermentes közegben $120{ }^{\circ} \mathrm{C}$-on, mikrohullámú melegítés segítségével (35. ábra, A módszer). A szakirodalomban megtalálható jó hozamokkal (78-88\%) ellentétben ${ }^{102}$ azonban a kromatográfiás tisztítást követően csak kis mennyiségü (20-25\%) heterociklusos származék (25a és 25b) keletkezését tapasztaltuk. A 17-es vegyület VRK-n megfigyelt teljes konverziója során számos nem azonosított poláris melléktermék keletkezését figyeltük meg, melyek csökkentették a kívánt termékek hozamát. A reakciót az oldószermentes körülménnyel azonos reagensarány és hőmérséklet alkalmazásával etanolos közegben is megismételtük (35. ábra, $B$ módszer). A mikrohullámú besugárzást ebben az esetben 15 percre növeltük, a kiindulási anyag teljes átalakulása érdekében. Az oldószer alkalmazásával a tisztítást követően a pirimidinszármazékokat (25a és 25b) körülbelül 10\%-kal magasabb hozamokkal (31-36\%) sikerült kinyerni.

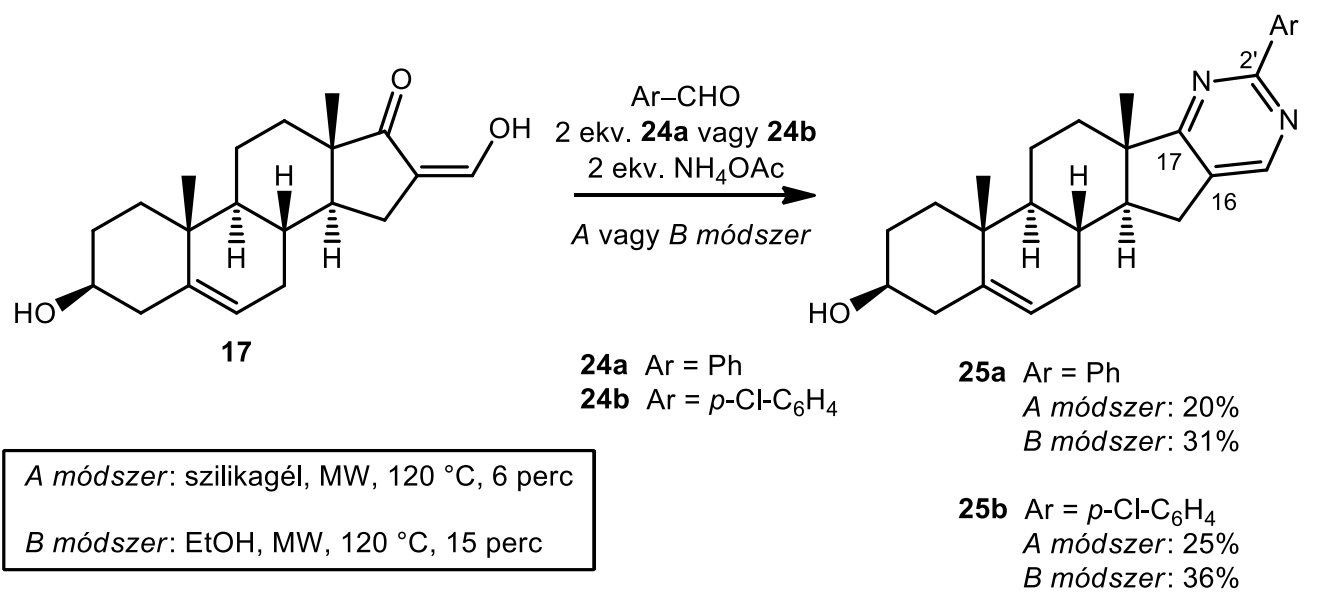

35. ábra: A 16-hidroximetilén-dehidroepiandroszteon (17), arilaldehidek (24a, 24b) és ammónium-acetát reakciói oldószermentes és etanolos közegben 
A korábbi kísérleteinkhez hasonlóan ebben az esetben is meg kívántuk vizsgálni a szteránváz hattagú A- és öttagú D-gyürüjének reaktivitásbeli különbségét a ciklizációs folyamatban. Az összehasonlításhoz kiindulási anyagként 2-hidroximetilén-5 $\alpha$ dihidrotesztoszteront (21) választottunk, melyet a D-gyürün etanolban végzett reakcióval megegyező körülmények és azonos reagensarány mellett először benzaldehiddel (24a) és $\mathrm{NH}_{4} \mathrm{OAc}$-tal reagáltattunk. A hattagú A-gyürün a keletkező vázhoz kondenzált heterociklus hozama 45\%-ra nőtt. A reagensek anyagmennyiség arányainak optimalizálásával (21:24a: $\left.\mathrm{NH}_{4} \mathrm{OAc}=1: 5: 5\right)$ a pirimidinszármazék elérhető maximális mennyisége $60 \%$-ra emelkedett (36. ábra). Az eredmények alátámasztották azt a korábbi megállapításunkat, hogy a viszonylag merev és sztérikusan gátolt D-gyürü kevésbé reaktív, mint a flexibilisebb A-gyürü a hattagú kondenzált heterociklusok szintézise során. ${ }^{110}$
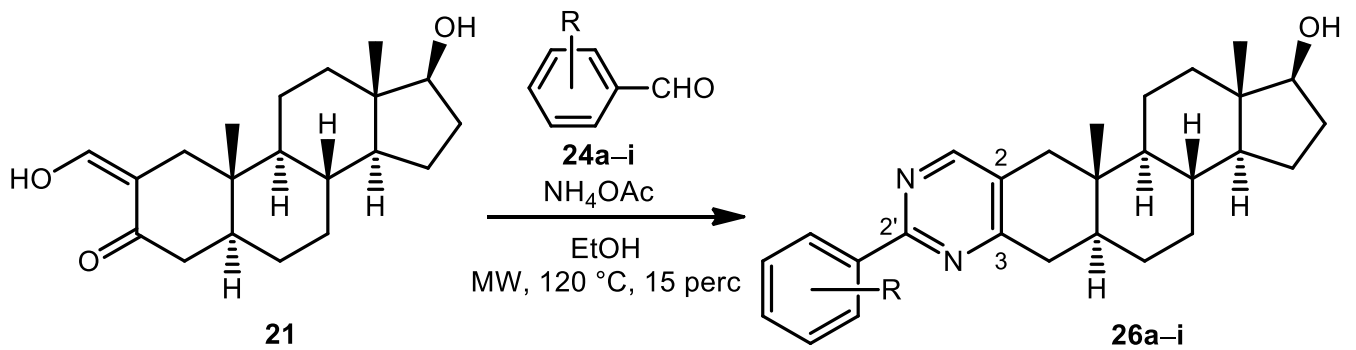

\begin{tabular}{cccc}
\hline Aldehid $^{*}$ & $\mathrm{R}$ & Termék & $\begin{array}{c}\text { Hozam }^{* *} \\
(\%)\end{array}$ \\
\hline 24a & $\mathrm{H}$ & $\mathbf{2 6 a}$ & 60 \\
$\mathbf{2 4 b}$ & $p-\mathrm{Cl}$ & $\mathbf{2 6 b}$ & 62 \\
$\mathbf{2 4 c}$ & $p-\mathrm{Br}$ & $\mathbf{2 6 c}$ & 62 \\
$\mathbf{2 4 d}$ & $p-\mathrm{F}$ & $\mathbf{2 6 d}$ & 60 \\
$\mathbf{2 4 e}$ & $p-\mathrm{NO}_{2}$ & $\mathbf{2 6 e}$ & 69 \\
$\mathbf{2 4 f}$ & $p-\mathrm{OMe}^{*}$ & $\mathbf{2 6 f}$ & 44 \\
$\mathbf{2 4 g}$ & $p-\mathrm{CH}_{3}$ & $\mathbf{2 6 g}$ & 49 \\
$\mathbf{2 4 h}$ & $m-\mathrm{CH}_{3}$ & $\mathbf{2 6 h}$ & 43 \\
$\mathbf{2 4 i}$ & $o-\mathrm{CH}_{3}$ & $\mathbf{2 6 i}$ & 10 \\
\hline
\end{tabular}

*A reaktánsok mólaránya: 21:24: $\mathrm{NH}_{4} \mathrm{OAc}=1: 5: 5$

** oszlopkromatográfiás tisztítást követöen

36. ábra: Androsztánváz A-gyürüjéhez kondenzált pirimidinszármazékok előállítása

A továbbiakban hasonló 2'-arilpirimidinek multikomponensü szintézisét végeztük el a korábbiakban optimalizált reakciókörülmények mellett orto-, meta- és para-szubsztituált benzaldehid származékokkal (24g-i) abból a célból, hogy megvizsgáljuk a reagens aromás gyürüjén található R szubsztituens sztérikus hatását a folyamat kimenetelére. A kiindulási bifunkciós szteroid orto- (24i) meta- (24h) és para-tolualdehiddel (24g), ammónium-acetát jelenlétében végzett reakciói során kimutattuk a szubsztituens helyzetének befolyását a 
ciklizációs folyamatra. Minél távolabb helyezkedett el az R csoport a reakciócentrumtól, annál nagyobb volt a keletkezett termék hozama (36. ábra). A 24i reagens orto-helyzetü szubsztituense jelentős sztérikus gátlást gyakorolt a gyürüzárási folyamatra. Ebben az esetben melléktermékként olyan vegyületet is izoláltunk, melynek ${ }^{1} \mathrm{H}-\mathrm{NMR}$ spektrumán jól látszott, hogy két orto-tolualdehid (24i) épült be a molekulába a szteránvázhoz kondenzált nitrogéntartalmú heterociklus kialakulása nélkül. Ez utóbbi mellékreakció a többi reagens alkalmazásakor is elképzelhető, valamint a multikomponensü reakciók során más melléktermékek keletkezésére is van mód, mivel a három reaktáns változatos módon képes reakcióba lépni egymással. Ez lehet a fö oka a szintézisek során kapott mérsékelt termékhozamoknak. Mivel a kondenzált heterociklusos származék legnagyobb hozamát para-tolualdehidnél értük el, a funkciós csoportok elektronikus hatásának feltérképezésére különböző para-szubsztituált benzaldehidekkel (24b-g) további kísérleteket végeztünk (36. ábra). Az elektronvonzó ( $\left.\mathrm{F}, \mathrm{Cl}, \mathrm{Br}, \mathrm{NO}_{2}\right)$ szubsztituenst tartalmazó reagensek (24b-e) esetén nagyobb mennyiségü kondenzált arilpirimidin származék keletkezését figyeltük meg, mint az elektronküldő $\left(\mathrm{CH}_{3}, \mathrm{OMe}\right)$ funkciós csoportot tartalmazó arilaldehideknél (24f, 24g). Mind a sztérikus, mind az elektronikus hatás jól magyarázható a 37. ábrán szereplő feltételezett reakciómechanizmussal.

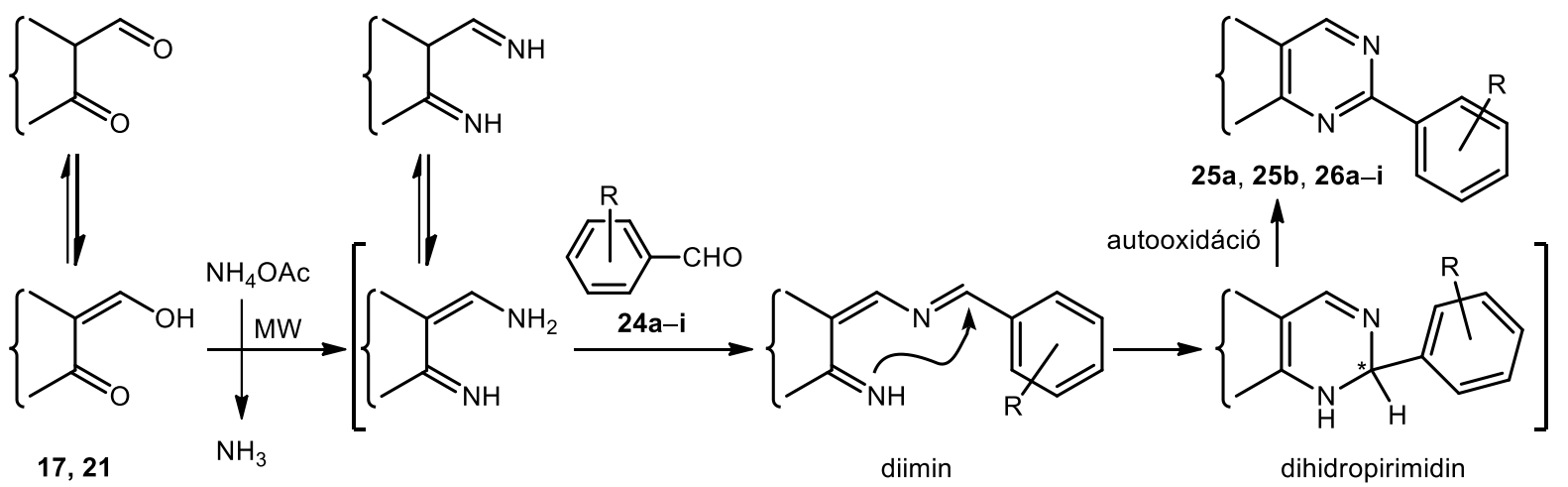

37. ábra: Az 1,3-ketoaldehid, az aromás aldehid és az ammónium-acetát multikomponensü reakciójának javasolt mechanizmusa

A folyamat első lépésében egy diimin intermedier képződik, melyben az aromás gyürü elektronvonzó R szubsztituense növeli, míg az elektronküldő funkciós csoportja csökkenti a fenilcsoport mellett lévő imin-szénatom parciális pozitív töltését, így elősegíti vagy akadályozza a ketimin nitrogénjének intramolekuláris nukleofil támadását. A gyürüzárást a reakciócentrumhoz közeli orto-helyzetü funkciós csoport sztérikusan gátolja. A háromkomponensü reakcióban először dihidropirimidinek epimer elegye keletkezik, mely a 
reakciókörülmények, valamint a levegő oxigénjének hatására autooxidációs folyamatban pirimidinné alakul (37. ábra).

A következőkben hasonló, A-gyürühöz kondenzált pirimidinszármazékok szintézisét végeztük el egy másik multikomponensű folyamat segítségével. Mivel a korábbi kísérleteink azt mutatták, hogy a D-gyürü reaktivitása az A-gyürühöz képest kisebb, így az öttagú gyürühöz anellált heterociklusok előállítási lehetőségeit ez esetben nem vizsgáltuk. A módosított Biginelli-reakció kiindulási anyagának a $17 \beta$-acetoxi-5 $\alpha$-dihidrotesztoszteront (10) választottuk, melyet benzaldehiddel (24a) és $p$-szubsztituált arilaldehidekkel (24b-g) valamint karbamiddal reagáltattunk (38. ábra). Elöször a 10:24a:karbamid = 1:2:1 mólarányú keverékét ecetsavas közegben, katalitikus mennyiségű kénsav hozzáadásával, 10 percig mikrohullámú besugárzás segítségével $110{ }^{\circ} \mathrm{C}$-on melegítettük. A szintézis végén a VRK lapon 3 új foltot észleltünk. Az NMR mérések alapján a két, közel azonos $R_{\mathrm{f}}$ értékkel rendelkező komponens a reakció során újonnan kialakuló aszimmetriacentrum miatt keletkezett dihidropirimidinon diasztereomerek (27a-4'R és 27a-4'S) oszlopkromatográfiával nem elválasztható 3:1 arányú keveréke volt.

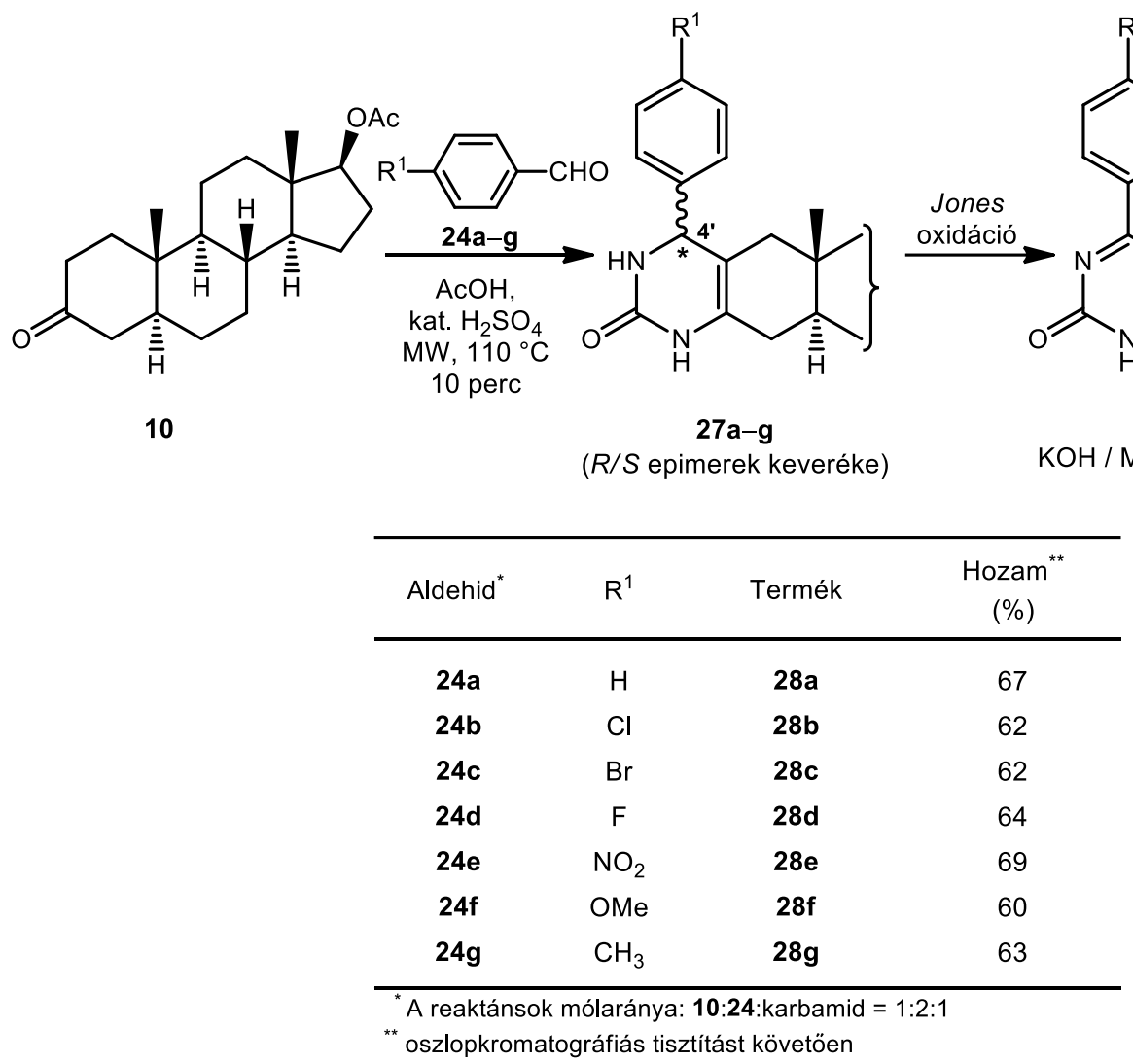

38. ábra: A Biginelli-típusú reakcióval előállított szteránvázas pirimidinonok szintézise

A spektroszkópiai adatok alapján a kromatogramon észlelt harmadik folt az elegyben katalizátorként jelenlévő kénsav oxidáló hatására keletkező pirimidinon (28a) származéknak 
felelt meg. A multikomponensü reakció során létrejött kiralitáscentrum megszüntetése érdekében az elsődlegesen képződő izomerkeverék oxidációja mellett döntöttünk. Mivel a dihidropirimidinonok dehidrogénezése erélyes oxidálószert igényel, ezért a szintézist Jonesreagenssel végeztük el. A folyamat eredményeként az androsztánváz A-gyürüjéhez kondenzált pirimidinont 67\%-os hozammal kaptuk. Az oxidációs lépés további előnye volt, hogy a kromatográfiás tisztítást megnehezítő, feleslegben alkalmazott benzaldehidtől (24a) is sikerült megszabadulnunk. Ezt követően az alkalmazott arilaldehidek (24b-g) szubsztituenseinek hatását vizsgáltuk a multikomponensủ reakciók során (38. ábra), de az izolált termékek (28b-g) hozamai (60-69\%) között jelentős különbséget nem tapasztaltunk.

A 17ß-OH származékokat (29a-g) - melyek az esetek többségében nagyobb biológiai aktivitással rendelkeznek, ${ }^{10}$ mint acetátjaik (28a-g) - lúgos közegü dezacetilezéssel állítottuk elő, kiváló hozamokkal (> 90\%).

A szintetizált szteránvázhoz kondenzált pirimidinek (25a, 25b, 26a-i) és pirimidinonok (28a-g, 29a-g) szerkezetét ${ }^{1} \mathrm{H}$ - és ${ }^{13} \mathrm{C}$-NMR spektroszkópiával bizonyítottuk. A vegyületek a korábbiakhoz hasonlóan in vitro farmakológiai vizsgálatokra kerültek, melyek eredményét az 5. fejezet ismerteti. 


\section{Az in vitro farmakológiai vizsgálatok eredményei}

Az elöállított vegyületek in vitro sejtosztódásgátlási vizsgálatait az SZTE GYTK Gyógyszerhatástani és Biofarmáciai Intézetében (5a-c, 9a-f, 13a-h, 13g', 14a-h, 14g', 19a-h, 20a-h, 22a-h, 23a-h származékok esetében) különböző humán adherens nőgyógyászati daganatos sejtvonalakon, valamint az SZTE TTIK Biokémiai és Molekuláris Biológiai Tanszékén (25a, 25b, 26a-i, 28a-g, 29a-g) egy méhnyak és kétféle prosztata ráksejtvonalon végezték el. A vizsgálatokat eltérő vegyület koncentrációkat alkalmazva MTT assay ${ }^{127}$ segítségével hajtották végre. A százalékos sejtosztódás gátlási és számított IC $_{50}$ értékeket (az a koncentráció, ahol a sejtek fele elpusztul) tartalmazó táblázat a mellékletben található.

A szteránvázhoz kondenzált kinolinszármazékok antiproliferatív hatását 3 méhnyak(C33A, HeLa, SiHa) és 4 emlőrák (MCF7, MDA-MB-231, MDA-MB-361, T47D) sejtvonalon vizsgálták. Az MTT méréseket 10 és $30 \mu \mathrm{M}$ koncentrációban végezték 72 órás inkubációs idővel, referenciaként ciszplatint alkalmazva. A magasabb $(30 \mu \mathrm{M}$ koncentrációnál legalább 50\%) sejtosztódás gátlási értékkel rendelkező származékok $\mathrm{IC}_{50}$ értékeit is meghatározták. A D-gyürühöz kondenzált származékok (5a-c) a vizsgálatok során csak csekély mértékben bizonyultak hatásosnak, csupán 30-50\%-os gátlást mutattak a magasabb koncentrációban alkalmazva. A tetralonból képzett benz $[c]$ akridinek $(\mathbf{9 a}-\mathbf{f})$ az előbbiekhez képest gyengébb eredményekkel rendelkeztek, kivéve a 9e és 9f származékokat, melyek a referenciaként használt ciszplatinnal összemérhető aktivitást mutattak. Az A-gyürühöz kondenzált heterociklusos anyagok közül a 17ß-OAc származékok (13a-c, 13e-g) a megfelelö $17 \beta-\mathrm{OH}$ vegyületekhez (14a-c, 14e-f) képest kevésbé bizonyultak hatásosnak a proliferációs vizsgálatokban. A 14-es vegyületeknél a heterogyürü funkciós csoportjának minősége nem mutatott szignifikáns hatást a biológiai aktivitásra, azonban a 6'-pozícióban lévő szubsztituens kedvezőnek tünt az assay során. A heterogyürü 6'-helyzetében OMe és a szteránváz 17-es pozíciójában $\mathrm{OH}$ csoportot tartalmazó vegyület (14c) a ciszplatinnal összemérhető aktivitást mutatott a T47D sejtvonalon, így további sejtciklus és kaszpáz-3 enzim indukciós vizsgálatoknak vetették alá. A mérések alapján a vegyület bizonyíthatóan szerepet játszott a programozott sejthalál beindításában.

Az androsztánvázhoz kondenzált pirazolok hatástani vizsgálatait 3 különböző nőgyógyászati adenocarcinomán (MCF7, T47D, MDA-MB-231) a kinolinszármazékokkal azonos koncentrációk (10 és $30 \mu \mathrm{M}$ ) alkalmazásával végezték el, referenciaként ciszplatint 
használva. Az eredmények alapján általánosságban elmondható, hogy a 19-es vagy a 22-es vegyületek nagyobb hatásfokkal gátolták a rákos sejtek osztódását, mint a megfelelő 20-as vagy 23-as régióizomer párjaik. A heterogyürü szteránvázon elfoglalt pozícióját tekintve a D-gyürühöz kondenzált pirazolszármazékok (ezen belül is a 19a-h vegyületek) bizonyultak aktívabbnak az in vitro vizsgálatok során. Az A-gyürühöz anellált molekulák (22a-h) esetében ugyanakkor kis mértékü szubsztituenshatás is megfigyelhetó volt. A szubsztituálatlan fenilcsoportot (22a), a $p-\mathrm{CH}_{3}$ (22b) vagy a leginkább $p-\mathrm{F}$ (22d) funkciós csoportot tartalmazó vegyületek bizonyultak a leghatásosabbnak. A nagyobb térkitöltésü $(\mathrm{OMe}, \mathrm{Cl}, \mathrm{Br})$ vagy az erősen elektronvonzó csoporttal $\left(\mathrm{CN}, \mathrm{NO}_{2}\right)$ rendelkező származékok kevésbé gátolták a rákos sejtek proliferációját. A legjobb eredménnyel rendelkező A- és Dgyürüs származékok (19g és $\mathbf{2 2 g}$ ) sejtciklusra gyakorolt aktivitását is megvizsgálták.

A szteránvázas pirimidin- (25a, 25b, 26a-i) és pirimidinongyürüt (28a-g, 29a-g) tartalmazó analogonokat egy méhnyak- (MCF7) és két különböző prosztatarák (DU145 és PC3) sejtvonalon, emellett összehasonlításként egészséges (MRC5) sejteken is vizsgálták. A korábbiaktól eltérően az in vitro MTT méréseket rövidebb ideig (24 óra) magasabb koncentrációban $(64 \mu \mathrm{M})$ végezték el a ciszplatin mellett doxorubicin referenciavegyület alkalmazásával is. A Biginelli-reakcióval elöállított vegyületek esetén a 17ß-OAc származékok (28a-g) minden esetben szinte a teljes sejtállományt elpusztították a vizsgált időtartamon belül. A 17ß-OH megfelelöik közül néhány mérsékelt aktivitással rendelkezett, de ráksejt szelektivitás nem volt megfigyelhető. Az első típusú multikomponensű reakcióval előállított származékok közül 3 (25b, 26d, 26h) citotoxikusnak és szelektívnek bizonyult prosztatarák sejtvonalon. A vegyületek $\mathrm{IC}_{50}$ értékei mindkét referencia anyagnál alacsonyabbnak bizonyultak a rákos sejtvonalakon, míg az egészséges sejteket a doxorubicinnél kevésbé pusztították.

Az in vitro farmakológiai eredmények alapján elmondható, hogy az általunk szintetizált származékok közül számos vegyület direkt citotoxikus vagy antiproliferatív hatásúnak bizonyult a vizsgált humán daganatos sejtvonalakon. 


\section{6. Általános kísérleti rész}

A mikrohullámú aktiválással végzett reakciókat CEM Discover SP készülékkel hajtottuk végre.

A ${ }^{1} \mathrm{H}$ - és ${ }^{13} \mathrm{C}-\mathrm{NMR}$ spektrumok felvétele Bruker DRX500 készülékkel történt, a ${ }^{1} \mathrm{H}-\mathrm{NMR}$ esetén a $\mathrm{CDCl}_{3}$ szingulett jelét ( $\left.\delta=7,26 \mathrm{ppm}\right)$, a ${ }^{13} \mathrm{C}-\mathrm{NMR}$ esetén a $\mathrm{CDCl}_{3}$ triplett jelét ( $\delta=77,0 \mathrm{ppm}$ ) használva belső standardként. A mérések során használt egyéb deuterált oldószereket (DMSO- $\left.\mathrm{d}_{6}, \mathrm{CD}_{3} \mathrm{OD}\right)$ a megfelelő adatoknál tüntettük fel.

Az IR spektrumok felvétele Jasco FT/IR-4700 készülékkel történt ATR feltétet használva.

Az olvadáspontokat SRS Optimelt digitális olvadáspontmérővel határoztuk meg az értékek korrekciója nélkül.

A tömegspektrumok Agilent 1100/Agilent 1946A HPLC/MS készülékkel, ESI ionizációs technikával készültek.

Az elemanalízisek meghatározása Perkin Elmer CHN 2400 készülékkel történt. A szén és hidrogén analízisek során nyert adatok mért és számított értékei a hibahatáron belül megegyeztek egymással.

A reakciótermékek elválasztása, illetve tisztítása 40-63 $\mu \mathrm{m}$ szemcseméretü Kieselgel 60 (MERCK) típusú álló fázissal töltött oszlopon történt. A reakciók lefutását VRK-val követtük, Kieselgel 60 F254 (MERCK), 0,2 mm vastagságú lapokat használva. A kromatogramokat a következö összetételü reagenssel való lefújással, és azt követő 10 perces 100-120 ${ }^{\circ} \mathrm{C}$-on történő melegítéssel hívtuk elö: $2,5 \mathrm{~g} \mathrm{P}_{2} \mathrm{O}_{5} \cdot 24 \mathrm{MoO}_{3} \cdot \mathrm{H}_{2} \mathrm{O}, 25 \mathrm{ml} 85 \%$-os $\mathrm{H}_{3} \mathrm{PO}_{4}, 25 \mathrm{ml}$ víz.

A retenciós faktorokat $\left(R_{\mathrm{f}}\right) 254$ és/vagy $365 \mathrm{~nm}$ hullámhosszúságú UV-fényben észlelt foltok alapján határoztuk meg. Az $R_{\mathrm{f}}$-értékek számítása során alkalmazott egyes oldószereket vagy oldószerelegyeket a vegyületek megfelelő adatainál jelöltük.

Az előállított vegyületek ${ }^{1} \mathrm{H}$ - és ${ }^{13} \mathrm{C}$-NMR, valamint MS-adatait a Melléklet tartalmazza. 


\section{Részletes kísérleti rész}

\section{1. $\beta$-klórvinil-aldehidek előállítása (általános szintézismódszer)}

Ösztron-3-metil-éter (1, 5,69g, 20,0 mmol), 6-metoxi-1-tetralon (6, 3,52 g, 20,0 mmol) vagy

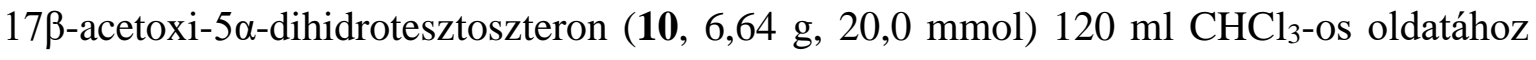
jeges hütés mellett $30 \mathrm{ml} \mathrm{POCl}_{3}$-ot és $30 \mathrm{ml}$ DMF-et egyszerre hozzácsepegtettünk. Az elegyet $0{ }^{\circ} \mathrm{C}$-on 10 percig kevertük, majd hagytuk szobahőmérsékletüre melegedni. Ezután 4 órán keresztül forraltuk ( $A$ módszer, 1, 6, vagy $\mathbf{1 0}$ esetén), vagy $25^{\circ} \mathrm{C}$-on kevertük 2 órán keresztül (B módszer, 10 esetén). A reakcióidő letelte után a reakcióelegyet jégre öntöttük, $\mathrm{CH}_{2} \mathrm{Cl}_{2}$-nal extraháltuk $(3 \times 50 \mathrm{ml})$ és a szerves fázist $\mathrm{NH}_{4} \mathrm{Cl}$-dal mostuk. Az egyesített szerves fázist izzított $\mathrm{Na}_{2} \mathrm{SO}_{4}$-on szárítottuk, majd bepároltuk. A nyersterméket oszlopkromatográfiával tisztítottuk.

\subsubsection{7-klór-3-metoxiösztra-1,3,5(10),16-tetraén-16-karbaldehid (2)}

Kiindulási vegyület: 1. Az oszlopkromatográfiás tisztítás hexán: $\mathrm{CH}_{2} \mathrm{Cl}_{2}=25: 75$ eluenssel történt. Termékek: 2 (4,43g, 67\%), fehér szilárd anyag és $3^{111}(0,91 \mathrm{~g}, 15 \%)$ fehér szilárd anyag.

Olvadáspont: $129-131^{\circ} \mathrm{C} ; \mathrm{C}_{20} \mathrm{H}_{23} \mathrm{ClO}_{2}, \mathrm{M}_{\mathrm{r}}=330,85$.

\subsection{Steránvázhoz kondenzált kinolinok (5 és 13) és benz[c]akridinek (9) előállítása} (általános szintézismódszer)

1,00 mmol szteránvázas ( 2 vagy $\mathbf{1 1}$ ) vagy nem szteroid $\beta$-klórvinil-aldehid (7), 1,00 mmol (szubsztituált) anilin (4a-i) $3 \mathrm{ml}$ DMF-es elegyét zárt reaktorcsőben, mikrohullámmal 140 ${ }^{\circ} \mathrm{C}$-ra vagy $120^{\circ} \mathrm{C}$-ra melegítettünk. A reakcióidő leteltével az elegyet $10 \mathrm{ml}$ vízre öntöttük és a kivált csapadékot szürtük, szárítottuk. A nyersterméket oszlopkromatográfiával tisztítottuk.

\subsubsection{3-Metoxiösztra-1,3,5(10),16-tetraeno[16,17:3',2']kinolin (5a)}

A reakcióhoz $331 \mathrm{mg}$ ösztránvázas $\beta$-klórvinil-aldehidet (2) és 0,091 ml anilint (4a) használtunk. Hőmérséklet: $140{ }^{\circ} \mathrm{C}$, reakcióidő 20 perc. A nyersterméket $\mathrm{CH}_{2} \mathrm{Cl}_{2}$ eluenssel tisztítottuk. A fehér szilárd termék (5a) tömege: $196 \mathrm{mg}$ (53\%).

Olvadáspont: $179-181{ }^{\circ} \mathrm{C} ; \mathrm{C}_{26} \mathrm{H}_{27} \mathrm{NO}, \mathrm{M}_{\mathrm{r}}=369,50$. 


\subsubsection{3-Metoxiösztra-6' -metil-1,3,5(10),16-tetraeno[16,17:3',2']kinolin (5b)}

A reakcióhoz $331 \mathrm{mg}$ ösztránvázas $\beta$-klórvinil-aldehidet (2) és $107 \mathrm{mg} p$-toluidint (4b) használtunk. Hőmérséklet: $140{ }^{\circ} \mathrm{C}$, reakcióidő 10 perc. A nyersterméket $\mathrm{CH}_{2} \mathrm{Cl}_{2}$ eluenssel tisztítottuk. A fehér szilárd termék (5b) tömege: 207 mg (54\%).

Olvadáspont: $201-204{ }^{\circ} \mathrm{C} ; \mathrm{C}_{27} \mathrm{H}_{29} \mathrm{NO}, \mathrm{M}_{\mathrm{r}}=383,53$.

\subsubsection{3-Metoxiösztra-6'-metoxi-1,3,5(10),16-tetraeno[16,17:3',2']kinolin (5c)}

A reakcióhoz $331 \mathrm{mg}$ ösztránvázas $\beta$-klórvinil-aldehidet (2) és $123 \mathrm{mg}$ p-anizidint (4c) használtunk. Hőmérséklet: $140{ }^{\circ} \mathrm{C}$, reakcióidő 10 perc. A nyersterméket $\mathrm{CH}_{2} \mathrm{Cl}_{2}$ eluenssel tisztítottuk. A fehér szilárd termék (5c) tömege: $188 \mathrm{mg}$ (47\%).

Olvadáspont: $203-205^{\circ} \mathrm{C} ; \mathrm{C}_{27} \mathrm{H}_{29} \mathrm{NO}_{2}, \mathrm{M}_{\mathrm{r}}=399,52$.

\subsubsection{5,6-Dihidro-3,9-dimetoxibenz $[c]$ akridin $(9 c)$}

A reakcióhoz $223 \mathrm{mg}$ nem szteroid $\beta$-klórvinil-aldehidet (7) és $123 \mathrm{mg} p$-anizidint (4c) használtunk. Hömérséklet: $120^{\circ} \mathrm{C}$, reakcióidő 2 perc. A nyersterméket $\mathrm{CH}_{2} \mathrm{Cl}_{2}$ eluenssel tisztítottuk. A sárgásfehér szilárd termék (9c) tömege: 259 mg (89\%).

Olvadáspont: $135-137^{\circ} \mathrm{C} ; \mathrm{C}_{19} \mathrm{H}_{17} \mathrm{NO}_{2}, \mathrm{M}_{\mathrm{r}}=291,13$.

\subsubsection{1-Klór-5,6-dihidro-3-metoxibenz $[c]$ akridin (9d)}

A reakcióhoz $223 \mathrm{mg}$ nem szteroid $\beta$-klórvinil-aldehidet (7) és 0,10 $\mathrm{ml} o$-klóranilint (4d) használtunk. Hömérséklet: $120{ }^{\circ} \mathrm{C}$, reakcióidő 20 perc. A nyersterméket hexán: $\mathrm{CH}_{2} \mathrm{Cl}_{2}=70: 30$ eluenssel tisztítottuk. A sárgásfehér szilárd termék (9d) tömege: $104 \mathrm{mg}(35 \%)$.

Olvadáspont: $143-145^{\circ} \mathrm{C} ; \mathrm{C}_{18} \mathrm{H}_{14} \mathrm{ClNO}, \mathrm{M}_{\mathrm{r}}=295,76$.

\subsubsection{9-Klór-5,6-dihidro-3-metoxibenz $[c]$ akridin $(9 \mathrm{e})$}

A reakcióhoz $223 \mathrm{mg}$ nem szteroid $\beta$-klórvinil-aldehidet (7) és $128 \mathrm{mg} p$-klóranilint (4e) használtunk. Hőmérséklet: $120{ }^{\circ} \mathrm{C}$, reakcióidő 10 perc. A nyersterméket EtOAc:hexán $=10: 90$ eluenssel tisztítottuk. A sárgásfehér szilárd termék (9e) tömege: $160 \mathrm{mg}(54 \%)$.

Olvadáspont: $122-124{ }^{\circ} \mathrm{C} ; \mathrm{C}_{18} \mathrm{H}_{14} \mathrm{ClNO}, \mathrm{M}_{\mathrm{r}}=295,76$. 


\subsubsection{9-Bróm-5,6-dihidro-3-metoxibenz[c]akridin (9f)}

A reakcióhoz $223 \mathrm{mg}$ nem szteroid $\beta$-klórvinil-aldehidet (7) és $172 \mathrm{mg} p$-brómanilint (4f) használtunk. Hőmérséklet: $120{ }^{\circ} \mathrm{C}$, reakcióidő 10 perc. A nyersterméket hexán: $\mathrm{CH}_{2} \mathrm{Cl}_{2}=20: 80$ eluenssel tisztítottuk. A narancssárga szilárd termék (9f) tömege: $211 \mathrm{mg}(62 \%)$.

Olvadáspont: $122-124{ }^{\circ} \mathrm{C} ; \mathrm{C}_{18} \mathrm{H}_{14} \mathrm{BrNO}, \mathrm{M}_{\mathrm{r}}=340,21$.

\subsubsection{7 $\beta$-Acetoxi-5 $\alpha$-androsztano[2,3: 3',2']kinolin (13a)}

A reakcióhoz $379 \mathrm{mg}$ androsztánvázas $\beta$-klórvinil-aldehidet (11) és 0,091 ml anilint (4a) használtunk. Hőmérséklet: $120{ }^{\circ} \mathrm{C}$, reakcióidő 5 perc. A nyersterméket EtOAc: $\mathrm{CH}_{2} \mathrm{Cl}_{2}=$ 10:90 eluenssel tisztítottuk. A fehér szilárd termék (13a) tömege: 317 mg (76\%).

Olvadáspont: $226-228^{\circ} \mathrm{C} ; \mathrm{C}_{28} \mathrm{H}_{35} \mathrm{NO}_{2}, \mathrm{M}_{\mathrm{r}}=417,58$.

\subsubsection{7ß-Acetoxi-6'-metil-5 $\alpha$-androsztano[2,3: 3',2']kinolin (13b)}

A reakcióhoz 379 mg androsztánvázas $\beta$-klórvinil-aldehidet (11) és 107 mg p-toluidint (4b) használtunk. Hőmérséklet: $120{ }^{\circ} \mathrm{C}$, reakcióidő 5 perc. A nyersterméket EtOAc: $\mathrm{CH}_{2} \mathrm{Cl}_{2}=$ 5:95 eluenssel tisztítottuk. A fehér szilárd termék (13b) tömege: $393 \mathrm{mg}$ (91\%).

Olvadáspont: $247-249{ }^{\circ} \mathrm{C} ; \mathrm{C}_{29} \mathrm{H}_{37} \mathrm{NO}_{2}, \mathrm{M}_{\mathrm{r}}=431,61$.

\subsubsection{7ß-Acetoxi-6'-metoxi-5 $\alpha$-androsztano[2,3: 3',2']kinolin (13c)}

A reakcióhoz 379 mg androsztánvázas $\beta$-klórvinil-aldehidet (11) és $123 \mathrm{mg} p$-anizidint (4c) használtunk. Hőmérséklet: $120{ }^{\circ} \mathrm{C}$, reakcióidő 2 perc. A nyersterméket EtOAc: $\mathrm{CH}_{2} \mathrm{Cl}_{2}=$ 5:95 eluenssel tisztítottuk. A fehér szilárd termék (13c) tömege: $412 \mathrm{mg}$ (91\%).

Olvadáspont: $247-249^{\circ} \mathrm{C} ; \mathrm{C}_{29} \mathrm{H}_{37} \mathrm{NO}_{3}, \mathrm{M}_{\mathrm{r}}=447,61$.

\subsubsection{7ß-Acetoxi-8'-klór-5 $\alpha$-androsztano[2,3: 3',2']kinolin (13d)}

A reakcióhoz $379 \mathrm{mg}$ androsztánvázas $\beta$-klórvinil-aldehidet (11) és $0,1 \mathrm{ml} o$-klóranilint (4d) használtunk. Hőmérséklet: $120^{\circ} \mathrm{C}$, reakcióidő 20 perc. A nyersterméket EtOAc: $\mathrm{CH}_{2} \mathrm{Cl}_{2}=$ 5:95 eluenssel tisztítottuk. A fehér szilárd termék (13d) tömege: 194 mg (43\%).

Olvadáspont: $310{ }^{\circ} \mathrm{C}$ felett bomlik; $\mathrm{C}_{28} \mathrm{H}_{34} \mathrm{ClNO}_{2}, \mathrm{M}_{\mathrm{r}}=452,03$. 


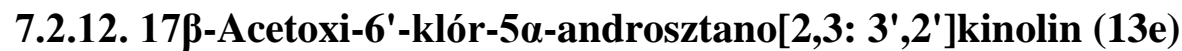

A reakcióhoz $379 \mathrm{mg}$ androsztánvázas $\beta$-klórvinil-aldehidet (11) és $128 \mathrm{mg}$ p-klóranilint (4e) használtunk. Hőmérséklet: $120{ }^{\circ} \mathrm{C}$, reakcióidő 10 perc. A nyersterméket EtOAc: $\mathrm{CH}_{2} \mathrm{Cl}_{2}=$ 5:95 eluenssel tisztítottuk. A fehér szilárd termék (13e) tömege: $267 \mathrm{mg}$ (59\%).

Olvadáspont: $288-291^{\circ} \mathrm{C}, \mathrm{C}_{28} \mathrm{H}_{34} \mathrm{ClNO}_{2}, \mathrm{M}_{\mathrm{r}}=452,03$.

\subsubsection{7ß-Acetoxi-6'-bróm-5 $\alpha$-androsztano[2,3: 3',2']kinolin (13f)}

A reakcióhoz $379 \mathrm{mg}$ androsztánvázas $\beta$-klórvinil-aldehidet (11) és $172 \mathrm{mg}$ p-brómanilint (4f) használtunk. Hőmérséklet: $120{ }^{\circ} \mathrm{C}$, reakcióidő 10 perc. A nyersterméket EtOAc: $\mathrm{CH}_{2} \mathrm{Cl}_{2}=5: 95$ eluenssel tisztítottuk. A fehér szilárd termék (13f) tömege: $298 \mathrm{mg}$ $(60 \%)$.

Olvadáspont: $295-297^{\circ} \mathrm{C}, \mathrm{C}_{28} \mathrm{H}_{34} \mathrm{BrNO}_{2}, \mathrm{M}_{\mathrm{r}}=496,48$.

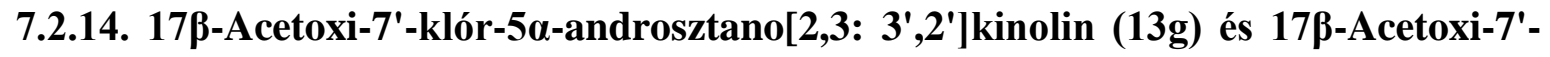
klór-5a-androsztano[2,3: 3',2']kinolin (13g')

A reakcióhoz 379 mg androsztánvázas $\beta$-klórvinil-aldehidet (11) és 0,1 $\mathrm{ml} m$-klóranilint (4g) használtunk. Hőmérséklet: $120^{\circ} \mathrm{C}$, reakcióidő 10 perc. A nyersterméket EtOAc: $\mathrm{CH}_{2} \mathrm{Cl}_{2}=$ 2:98 eluenssel tisztítottuk. A fehér szilárd termékek tömege: $\mathbf{1 3 g} 208$ mg (46\%) és $\mathbf{1 3 g} 72$ mg $(16 \%)$.

Olvadáspont: $258-260{ }^{\circ} \mathrm{C}(\mathbf{1 3 g})$ és $262-265^{\circ} \mathrm{C}\left(\mathbf{1 3 g} \mathbf{g}^{\prime}\right) \mathrm{C}_{28} \mathrm{H}_{34} \mathrm{ClNO}_{2}, \mathrm{M}_{\mathrm{r}}=452,03$.

\subsubsection{7ß-Acetoxi-8' -metil-5 $\alpha$-androsztano[2,3: 3',2']kinolin (13h)}

A reakcióhoz $379 \mathrm{mg}$ androsztánvázas $\beta$-klórvinil-aldehidet (11) és $0,1 \mathrm{ml} o$-toluidint (4h) használtunk. Hőmérséklet: $120{ }^{\circ} \mathrm{C}$, reakcióidő 5 perc. A nyersterméket EtOAc: $\mathrm{CH}_{2} \mathrm{Cl}_{2}=$ 5:95 eluenssel tisztítottuk. A fehér szilárd termék (13h) tömege: $315 \mathrm{mg}$ (73\%).

Olvadáspont: $262-265^{\circ} \mathrm{C} ; \mathrm{C}_{29} \mathrm{H}_{37} \mathrm{NO}_{2}, \mathrm{M}_{\mathrm{r}}=431,61$. 


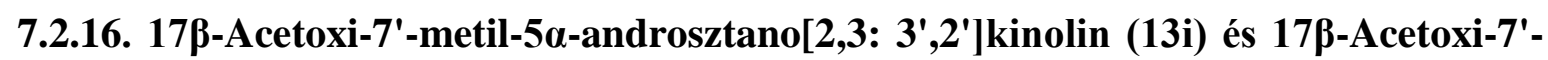
metil-5 $\alpha$-androsztano[2,3: 3',2']kinolin (13i')

A reakcióhoz $379 \mathrm{mg}$ androsztánvázas $\beta$-klórvinil-aldehidet (11) és $0,1 \mathrm{ml} m$-toluidint (4i) használtunk. Hőmérséklet: $120^{\circ} \mathrm{C}$, reakcióidő 2 perc. A termékek oszlopkromatogáfiával nem voltak elválaszthatók. A fehér szilárd termékek össztömege: 13i+13i' 388 mg (90\%). $\mathrm{C}_{29} \mathrm{H}_{37} \mathrm{NO}_{2}, \mathrm{M}_{\mathrm{r}}=431,61$.

\subsubsection{7ß-Acetoxi-3-[4'-nitrofenil]amino-5 $\alpha$-androszt-2-én-2-karbaldehid (15)}

A reakcióhoz $379 \mathrm{mg}$ androsztánvázas $\beta$-klórvinil-aldehidet (11) és $138 \mathrm{mg}$ p-niroanilint (4j) használtunk. Hőmérséklet: $120{ }^{\circ} \mathrm{C}$, reakcióidő 40 perc. A besugárzást követően a VRK-n nem tapasztaltunk változást. Az elegy 3 napos szobahőmérsékletü keverése után narancssárga szilárd anyag vált ki, melyet szürtünk, szárítottunk. A nyersterméket EtOAc: $\mathrm{CH}_{2} \mathrm{Cl}_{2}=2: 98$ eluenssel tisztítottuk. A narancssárga szilárd termék (15) tömege: $326 \mathrm{mg}(68 \%)$.

Olvadáspont: $270{ }^{\circ} \mathrm{C}$ felett bomlik, $\mathrm{C}_{28} \mathrm{H}_{36} \mathrm{~N}_{2} \mathrm{O}_{5}, \mathrm{M}_{\mathrm{r}}=480,60$.

\subsection{Androsztánváz A-gyürüjéhez kondenzált kinolinok 17ß-OH származékainak} előállítása (általános szintézismódszer)

0,3 mmol 17ß-OAc származékot (13) $10 \mathrm{ml}$ metanolban oldottunk és 1 mmol (56 mg) KOH-ot adtunk hozzá. A reakcióelegyet 2 órán keresztül szobahőmérsékleten kevertük, majd vízre öntöttük. A kivált csapadékot szürtük, vízzel mostuk, szárítottuk.

\subsubsection{7ß-Hidroxi-5 $\alpha$-androsztano[2,3: 3',2']kinolin (14a)}

Kiindulási anyag: 13a (125 mg). A kapott szilárd fehér anyag tömege: 101 mg (90\%).

Olvadáspont: $232-235{ }^{\circ} \mathrm{C} ; \mathrm{C}_{26} \mathrm{H}_{33} \mathrm{NO}, \mathrm{M}_{\mathrm{r}}=375,55$.

\subsubsection{7ß-Hidroxi-6'-metil-5 $\alpha$-androsztano[2,3: 3',2']kinolin (14b)}

Kiindulási anyag: 13b (129 mg). A kapott szilárd fehér anyag tömege: 106 mg (91\%).

Olvadáspont: $228-230{ }^{\circ} \mathrm{C} ; \mathrm{C}_{27} \mathrm{H}_{35} \mathrm{NO}, \mathrm{M}_{\mathrm{r}}=389,57$. 


\subsubsection{7ß-Hidroxi-6'-metoxi-5 $\alpha$-androsztano[2,3: 3',2']kinolin (14c)}

Kiindulási anyag: 13c (134 mg). A kapott szilárd fehér anyag tömege: 112 mg (92\%). Olvadáspont: $193-195{ }^{\circ} \mathrm{C} ; \mathrm{C}_{27} \mathrm{H}_{35} \mathrm{NO}_{2}, \mathrm{M}_{\mathrm{r}}=405,57$.

\subsubsection{7ß-Hidroxi-8'-klór-5a-androsztano[2,3: 3',2']kinolin (14d)}

Kiindulási anyag: 13d (136 mg). A kapott szilárd fehér anyag tömege: 112 mg (91\%). Olvadáspont: $300{ }^{\circ} \mathrm{C}$ felett bomlik; $\mathrm{C}_{26} \mathrm{H}_{32} \mathrm{ClNO}, \mathrm{M}_{\mathrm{r}}=409,99$.

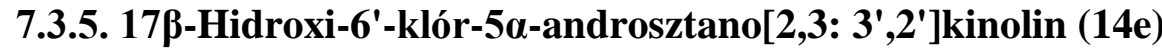

Kiindulási anyag: 13e (136 mg). A kapott szilárd fehér anyag tömege: $111 \mathrm{mg}(90 \%)$. Olvadáspont: $242-244{ }^{\circ} \mathrm{C} ; \mathrm{C}_{26} \mathrm{H}_{32} \mathrm{ClNO}, \mathrm{M}_{\mathrm{r}}=409,99$.

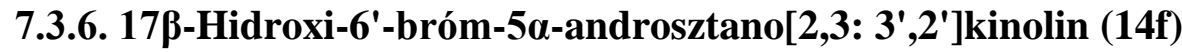

Kiindulási anyag: 13f (149 mg). A kapott szilárd fehér anyag tömege: 125 mg (92\%). Olvadáspont: $247-249^{\circ} \mathrm{C} ; \mathrm{C}_{26} \mathrm{H}_{32} \mathrm{BrNO}, \mathrm{M}_{\mathrm{r}}=454,44$.

\subsubsection{7ß-Hidroxi-7'-klór-5a-androsztano[2,3: 3',2']kinolin (14g)}

Kiindulási anyag: 13g (136 mg). A kapott szilárd fehér anyag tömege: $111 \mathrm{mg}(90 \%)$. Olvadáspont: $229-232{ }^{\circ} \mathrm{C} ; \mathrm{C}_{26} \mathrm{H}_{32} \mathrm{ClNO}, \mathrm{M}_{\mathrm{r}}=409,99$.

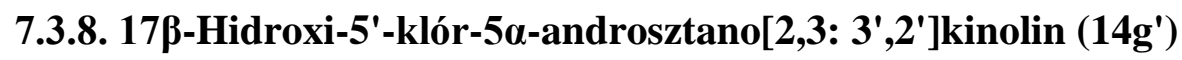

Kiindulási anyag: 13g' (136 mg). A kapott szilárd fehér anyag tömege: 112 mg (91\%). Olvadáspont: $140-142{ }^{\circ} \mathrm{C} ; \mathrm{C}_{26} \mathrm{H}_{32} \mathrm{ClNO}, \mathrm{M}_{\mathrm{r}}=409,99$.

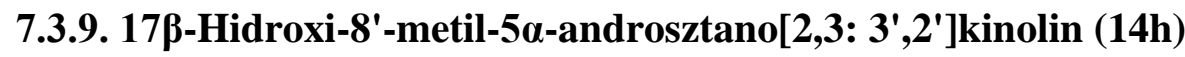

Kiindulási anyag: 13h (129 mg). A kapott szilárd fehér anyag tömege: 105 mg (90\%). Olvadáspont: $233-235{ }^{\circ} \mathrm{C} ; \mathrm{C}_{27} \mathrm{H}_{35} \mathrm{NO}, \mathrm{M}_{\mathrm{r}}=389,57$. 
7.4. A 16-hidroximetilén-androszt-5-én-3ß-ol-17-on (17) reakciói arilhidrazin-

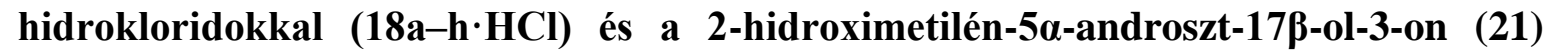
reakciója fenilhidrazin-hidrokloriddal (18a) savas etanolos közegben (általános szintézismódszer)

$10 \mathrm{ml}$ etanolban oldott 1,00 mmol kiindulási szteránvázas dikarbonil vegyület (17: $316 \mathrm{mg}$, vagy 21: $318 \mathrm{mg}$ ) és $0,3 \mathrm{mmol}(57 \mathrm{mg})$-TsOH elegyéhez $1,10 \mathrm{mmol}$ fenilhidrazinhidrokloridot $(\mathbf{1 8 a} \cdot \mathrm{HCl})$ vagy szubsztituált arilhidrazin-hidroklorid sót $(\mathbf{1 8 b}-\mathbf{h} \cdot \mathrm{HCl})$ adtunk. A reakcióelegyet 10 percen keresztül forraltuk (17 esetén) vagy szobahőmérsékleten kevertük (21 esetén). Az elegyet ezután vízre öntöttük, $\mathrm{NaHCO}_{3}$-tal semlegesítettük, majd $2 \times 10 \mathrm{ml} \mathrm{CH} \mathrm{Cl}_{2}$-nal extraháltuk. Az egyesített szerves fázist izzított $\mathrm{Na}_{2} \mathrm{SO}_{4}$-on szárítottuk és bepároltuk. A nyersterméket oszlopkromatográfiával tisztítottuk EtOAc: $\mathrm{CH}_{2} \mathrm{Cl}_{2}=10: 90$ eluens használatával. Elúciós sorrend: $20>19$, illetve $23>22$.

A $R_{\mathrm{f}}$ értékeket az alábbi oldószerelegyekkel (ss) határoztuk meg: (A) EtOAc: $\mathrm{CH}_{2} \mathrm{Cl}_{2}=5: 95$; (B) EtOAc: $\mathrm{CH}_{2} \mathrm{Cl}_{2}=10: 90 ;(\mathrm{C})$ EtOAc: $\mathrm{CH}_{2} \mathrm{Cl}_{2}=20: 80$.

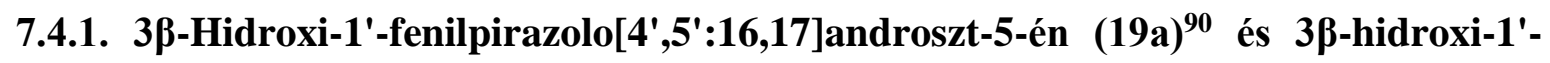
fenilpirazolo[4',3':16,17]androszt-5-én (20a)

A szintézishez a 17-es $\beta$-ketoaldehidet és $159 \mathrm{mg}$ fenilhidrazin-hidrokloridot $(\mathbf{1 8 a} \cdot \mathrm{HCl})$ használtunk. A kapott termékek tömege: 171 mg 19a (44\%, fehér szilárd anyag) és 160 mg 20a (41\%, fehér szilárd anyag). $R_{\mathrm{f}}=0,34$ (19a, ss C) és 0,46 (20a, ss C).

Olvadáspont: $229-231{ }^{\circ} \mathrm{C}$ (19a), $178-181{ }^{\circ} \mathrm{C}(\mathbf{2 0 a}) ; \mathrm{C}_{26} \mathrm{H}_{32} \mathrm{~N}_{2} \mathrm{O}, \mathrm{M}_{\mathrm{r}}=388,55$.

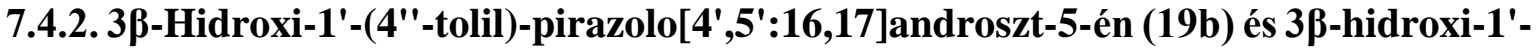
(4' '-tolil)-pirazolo[4',3':16,17]androszt-5-én (20b)

A szintézishez a 17-es $\beta$-ketoaldehidet és $174 \mathrm{mg}$ 4-tolilhidrazin-hidrokloridot $(\mathbf{1 8 b} \cdot \mathrm{HCl})$ használtunk. A kapott termékek tömege: 129 mg 19b (32\%, fehér szilárd anyag) és 222 mg $20 \mathrm{~b}\left(55 \%\right.$, fehér szilárd anyag). $R_{\mathrm{f}}=0,28(\mathbf{1 9 b}, \mathrm{ss} \mathrm{B})$ és $0,32(\mathbf{2 0 b}, \mathrm{ss} \mathrm{B})$.

Olvadáspont: $248-251{ }^{\circ} \mathrm{C}$ (19b), $250-253{ }^{\circ} \mathrm{C}(\mathbf{2 0 b}) ; \mathrm{C}_{27} \mathrm{H}_{34} \mathrm{~N}_{2} \mathrm{O}, \mathrm{M}_{\mathrm{r}}=402,57$. 


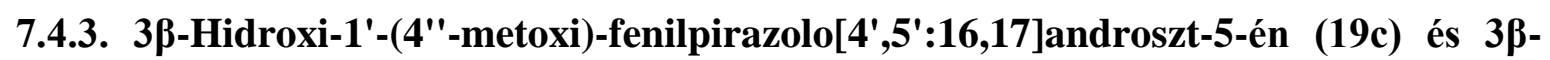
hidroxi-1'-(4' '-metoxi)-fenilpirazolo[4',3':16,17]androszt-5-én (20c) $)^{29}$

A szintézishez a 17-es $\beta$-ketoaldehidet és $192 \mathrm{mg}$ 4-metoxi-fenilhidrazin-hidrokloridot $(\mathbf{1 8 c} \cdot \mathrm{HCl})$ használtunk. A kapott termékek tömege: 108 mg 19c $(25 \%$, fehér szilárd anyag) és $230 \mathrm{mg} 20 \mathrm{c}\left(55 \%\right.$, fehér szilárd anyag). $R_{\mathrm{f}}=0,26(\mathbf{1 9 c}, \mathrm{ss} \mathrm{C})$ és $0,40(\mathbf{2 0 c}, \mathrm{ss} \mathrm{C})$.

Olvadáspont: $241-243{ }^{\circ} \mathrm{C}(\mathbf{1 9 c}), 224-226{ }^{\circ} \mathrm{C}(\mathbf{2 0 c}) ; \mathrm{C}_{27} \mathrm{H}_{34} \mathrm{~N}_{2} \mathrm{O}_{2}, \mathrm{M}_{\mathrm{r}}=418,57$.

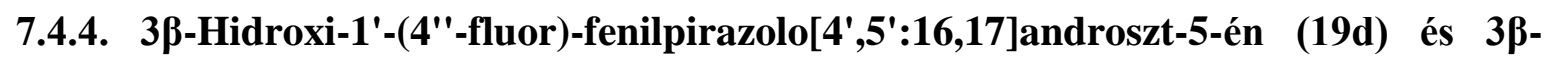
hidroxi-1'-(4''-fluor)-fenilpirazolo[4',3':16,17]androszt-5-én (20d)

A szintézishez a 17-es $\beta$-ketoaldehidet és $179 \mathrm{mg}$ 4-fluor-fenilhidrazin-hidrokloridot $(\mathbf{1 8 d} \cdot \mathrm{HCl})$ használtunk. A kapott termékek tömege: 216 mg 19d (53\%, fehér szilárd anyag) és $122 \mathrm{mg} \mathbf{2 0 d}$ (30\%, fehér szilárd anyag). $R_{\mathrm{f}}=0,34$ (19d, ss C) és 0,40 (20d, ss C).

Olvadáspont: $245-247^{\circ} \mathrm{C}(\mathbf{1 9 d}), 184-187^{\circ} \mathrm{C}(\mathbf{2 0 d}) ; \mathrm{C}_{26} \mathrm{H}_{31} \mathrm{FN}_{2} \mathrm{O}, \mathrm{M}_{\mathrm{r}}=406,54$.

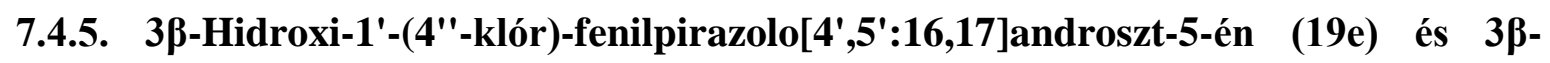
hidroxi-1'-(4"'-klór)-fenilpirazolo[4',3' :16,17]androszt-5-én (20e)

A szintézishez a 17-es $\beta$-ketoaldehidet és $197 \mathrm{mg}$ 4-klór-fenilhidrazin-hidrokloridot $(\mathbf{1 8 e} \cdot \mathrm{HCl})$ használtunk. A kapott termékek tömege: $224 \mathrm{mg}$ 19e $(53 \%$, fehér szilárd anyag) és $123 \mathrm{mg} \mathbf{2 0 e}\left(29 \%\right.$, fehér szilárd anyag). $R_{\mathrm{f}}=0,20$ (19e, ss B) és 0,28 (20e, ss B). Olvadáspont: $209-211^{\circ} \mathrm{C}(\mathbf{1 9 e}), 254-256{ }^{\circ} \mathrm{C}(\mathbf{2 0 e}) ; \mathrm{C}_{26} \mathrm{H}_{31} \mathrm{ClN}_{2} \mathrm{O}, \mathrm{M}_{\mathrm{r}}=422,99$.

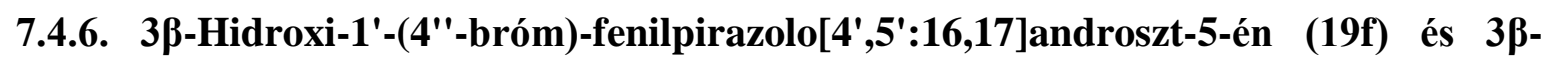
hidroxi-1'-(4' '-fluor)-fenilpirazolo[4',3':16,17]androszt-5-én (20f)

A szintézishez a 17-es $\beta$-ketoaldehidet és $246 \mathrm{mg}$ 4-bróm-fenilhidrazin-hidrokloridot $(\mathbf{1 8 f} \cdot \mathrm{HCl})$ használtunk. A kapott termékek tömege: $271 \mathrm{mg}$ 19f $(58 \%$, fehér szilárd anyag) és $126 \mathrm{mg} 20 f\left(27 \%\right.$, fehér szilárd anyag). $R_{\mathrm{f}}=0,22$ (19f, ss B) és 0,28 (20f, ss B).

Olvadáspont: $222-225^{\circ} \mathrm{C}$ (19f), 262-265 ${ }^{\circ} \mathrm{C}$ (20f); $\mathrm{C}_{26} \mathrm{H}_{31} \mathrm{BrN}_{2} \mathrm{O}, \mathrm{M}_{\mathrm{r}}=467,44$. 


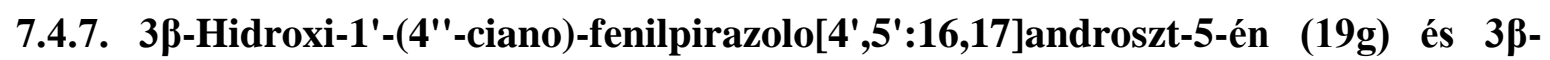
hidroxi-1'-(4' '-ciano)-fenilpirazolo[4',3':16,17]androszt-5-én (20g)

A szintézishez a 17-es $\beta$-ketoaldehidet és $187 \mathrm{mg}$ 4-ciano-fenilhidrazin-hidrokloridot $(\mathbf{1 8 g} \cdot \mathrm{HCl})$ használtunk. A kapott termékek tömege: 319 mg 19g (77\%, fehér szilárd anyag) és $41 \mathrm{mg} \mathbf{2 0 g}$ (10\%, olaj). $R_{\mathrm{f}}=0,26(\mathbf{1 9 g}$, ss B) és $0,30(\mathbf{2 0 g}, \mathrm{ss} \mathrm{B})$.

Olvadáspont: $237-239{ }^{\circ} \mathrm{C}(\mathbf{1 9 g}) ; \mathrm{C}_{27} \mathrm{H}_{31} \mathrm{~N}_{3} \mathrm{O}, \mathrm{M}_{\mathrm{r}}=413,55$.

\subsubsection{3ß-Hidroxi-1'-(4''-nitro)-fenilpirazolo[4',5':16,17]androszt-5-én (19h)}

A szintézishez a 17-es $\beta$-ketoaldehidet és 209 mg 4-nitro-fenilhidrazin-hidrokloridot $(\mathbf{1 8 h} \cdot \mathrm{HCl})$ használtunk. A kapott termék tömege: $365 \mathrm{mg}(84 \%$, sárga szilárd anyag).

$R_{\mathrm{f}}=0,26$ (ss B).

Olvadáspont: $237-239{ }^{\circ} \mathrm{C} ; \mathrm{C}_{26} \mathrm{H}_{31} \mathrm{BrN}_{3} \mathrm{O}_{3}, \mathrm{M}_{\mathrm{r}}=433,54$.

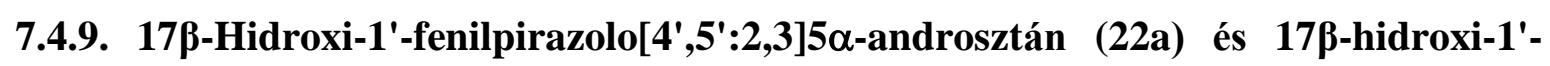
fenilpirazolo[ $4^{\prime}, 3$ ' $\left.: 2,3\right] 5 \alpha$ androsztán (23a)

A szintézishez a 21-es $\beta$-ketoaldehidet és $159 \mathrm{mg}$ fenilhidrazin-hidrokloridot $(\mathbf{1 8 a} \cdot \mathrm{HCl})$ használtunk. A kapott termékek tömege: 168 mg 22a (43\%, olaj) és 184 mg 23a (47\%, fehér szilárd anyag). $R_{\mathrm{f}}=0,40(\mathbf{2 2 a}, \mathrm{ss} \mathrm{C})$ és $0,46(\mathbf{2 3 a}, \mathrm{ss} \mathrm{C})$.

Olvadáspont: $238-241^{\circ} \mathrm{C}(\mathbf{2 3 a}) ; \mathrm{C}_{26} \mathrm{H}_{34} \mathrm{~N}_{2} \mathrm{O}, \mathrm{M}_{\mathrm{r}}=390,56$.

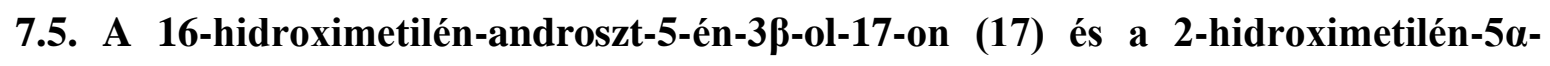

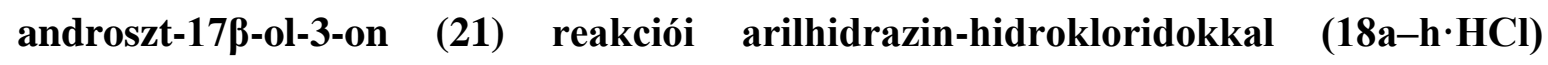
piridines közegben (általános szintézismódszer)

1,00 mmol kiindulási szteránvázas dikarbonil vegyület (17: $316 \mathrm{mg}$, vagy 21: $318 \mathrm{mg}$ ) $5 \mathrm{ml}$ piridines oldatához $1,10 \mathrm{mmol}$ fenilhidrazin-hidrokloridot $(\mathbf{1 8 a} \cdot \mathrm{HCl})$ vagy szubsztituált arilhidrazin-hidroklorid sót $(\mathbf{1 8 b}-\mathbf{h} \cdot \mathrm{HCl})$ adtunk. A reakcióelegyet 5 percig szobahőmérsékleten kevertük, majd $2,5 \mathrm{ml}$ cc. $\mathrm{H}_{2} \mathrm{SO}_{4}$-at tartalmazó jégre öntöttük. Szobahőmérsékletre történő felmelegedést követően $2 \times 10 \mathrm{ml} \mathrm{CH}_{2} \mathrm{Cl}_{2}$-nal extraháltuk. $\mathrm{Az}$ egyesített szerves fázist vízzel mostuk, ezután izzított $\mathrm{Na}_{2} \mathrm{SO}_{4}$-on szárítottuk és bepároltuk. A nyersterméket oszlopkromatográfiával tisztítottuk EtOAc: $\mathrm{CH}_{2} \mathrm{Cl}_{2}=5: 95$ (ss A) vagy EtOAc: $\mathrm{CH}_{2} \mathrm{Cl}_{2}=10: 90$ (ss B) eluenssel. A D-gyürün 1,3-dikarbonil molekularészt tartalmazó kiindulási anyagból (17) végzett szintézisek régiószelektíven a 19-es termékeket 
szolgáltatták, míg az A-gyürün bifunkciós szerkezeti elemet tartalmazó esetén minden kísérlet során a 22 és a 23 régióizomerek keverékét kaptuk. Elúciós sorrend: $23>22$. A $R_{\mathrm{f}}$ értékeket az alábbi oldószerelegyekkel (ss) határoztuk meg: (A) EtOAc: $\mathrm{CH}_{2} \mathrm{Cl}_{2}=5: 95$; (B) EtOAc: $\mathrm{CH}_{2} \mathrm{Cl}_{2}=10: 90 ;(\mathrm{C})$ EtOAc: $\mathrm{CH}_{2} \mathrm{Cl}_{2}=20: 80$.

\subsubsection{A 17-es vegyület reakciója fenilhidrazin-hidrokloriddal (18a)}

Az általános szintézismódszer szerint $159 \mathrm{mg}$ 18a reagenst használtunk. Eluens: ss B. Hozam: 335 mg (86\%) 19a.

\subsubsection{A 17-es vegyület reakciója 4-tolilhidrazin-hidrokloriddal (18b)}

Az általános szintézismódszer szerint $174 \mathrm{mg} \mathbf{1 8 b}$ reagenst használtunk. Eluens: ss B. Hozam: 363 mg (90\%) 19b.

\subsubsection{A 17-es vegyület reakciója 4-metoxi-fenilhidrazin-hidrokloriddal (18c)}

Az általános szintézismódszer szerint $192 \mathrm{mg}$ 18c reagenst használtunk. Eluens: ss B. Hozam: 344 mg (82\%) 19c.

\subsubsection{A 17-es vegyület reakciója 4-fluor-fenilhidrazin-hidrokloriddal (18d)}

Az általános szintézismódszer szerint $179 \mathrm{mg} \mathbf{1 8 d}$ reagenst használtunk. Eluens: ss B. Hozam: 346 mg (85\%) 19d.

\subsubsection{A 17-es vegyület reakciója 4-klór-fenilhidrazin-hidrokloriddal (18e)}

Az általános szintézismódszer szerint $197 \mathrm{mg}$ 18e reagenst használtunk. Eluens: ss B. Hozam: $351 \mathrm{mg}(83 \%)$ 19e.

\subsubsection{A 17-es vegyület reakciója 4-bróm-fenilhidrazin-hidrokloriddal (18f)}

Az általános szintézismódszer szerint $246 \mathrm{mg} 18 \mathrm{f}$ reagenst használtunk. Eluens: ss B. Hozam: 383 mg (82\%) 19f.

\subsubsection{A 17-es vegyület reakciója 4-ciano-fenilhidrazin-hidrokloriddal (18g)}

Az általános szintézismódszer szerint $187 \mathrm{mg} \mathbf{1 8 g}$ reagenst használtunk. Eluens: ss B. Hozam: $352 \mathrm{mg}(85 \%) \mathbf{1 9 g}$. 


\subsubsection{A 17-es vegyület reakciója 4-nitro-fenilhidrazin-hidrokloriddal (18h)}

Az általános szintézismódszer szerint 209 mg 18g reagenst használtunk. Eluens: ss B. Hozam: 369 mg (85\%) 19h.

\subsubsection{A 21-es vegyület reakciója fenilhidrazin-hidrokloriddal (18a)}

Az általános szintézismódszer szerint $159 \mathrm{mg}$ 18a reagenst használtunk. Eluens: ss B. Hozam: 196 mg (50\%) 22a és 192 mg (49\%) 23a.

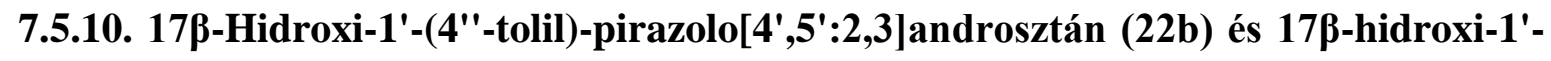
(4' '-tolil)-pirazolo[4',3':2,3]androsztán (23b)

Az általános szintézismódszer szerint a 21-es kindulási anyagot és $174 \mathrm{mg} \mathbf{1 8 b}$ reagenst használtunk. Eluens: ss B. Hozam: $182 \mathrm{mg}$ (45\%) 22b (fehér szilárd anyag) és $150 \mathrm{mg}$ (37\%) 23b (fehér szilárd anyag). $R_{\mathrm{f}}=0,39$ (22b, ss C) és 0,48 (23b, ss C).

Olvadáspont: $168-170{ }^{\circ} \mathrm{C}(\mathbf{2 2 b}), 211-214{ }^{\circ} \mathrm{C}(\mathbf{2 3 b}) ; \mathrm{C}_{27} \mathrm{H}_{36} \mathrm{~N}_{2} \mathrm{O}, \mathrm{M}_{\mathrm{r}}=404,59$.

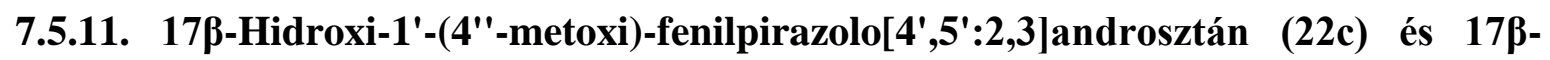
hidroxi-1'-(4''-metoxi)-fenilpirazolo[4',3':2,3] androsztán (23c)

Az általános szintézismódszer szerint a 21-es kindulási anyagot és $192 \mathrm{mg}$ 18c reagenst használtunk. Eluens: ss A. Hozam: 156 mg (37\%) 22c (olaj) és $189 \mathrm{mg}$ (45\%) 23c (fehér szilárd anyag). $R_{\mathrm{f}}=0,42$ (22c, ss C) és 0,40 (23c, ss A).

Olvadáspont: $198-200{ }^{\circ} \mathrm{C}(\mathbf{2 3 c}) ; \mathrm{C}_{27} \mathrm{H}_{36} \mathrm{~N}_{2} \mathrm{O}_{2}, \mathrm{M}_{\mathrm{r}}=420,59$.

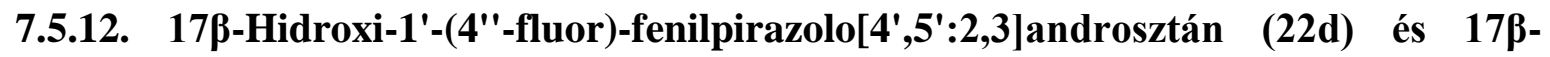
hidroxi-1'-(4''-fluor)-fenilpirazolo[4',3':2,3]androsztán (23d)

Az általános szintézismódszer szerint a 21-es kindulási anyagot és $179 \mathrm{mg} \mathbf{1 8 d}$ reagenst használtunk. Eluens: ss B. Hozam: 180 mg (44\%) 22d (olaj) és 143 mg (35\%) 23d (olaj). $R_{\mathrm{f}}=0,39(\mathbf{2 2 d}, \mathrm{ss} \mathrm{B})$ és $0,48(\mathbf{2 3 d}, \mathrm{ss} \mathrm{B})$.

$\mathrm{C}_{26} \mathrm{H}_{33} \mathrm{FN}_{2} \mathrm{O}, \mathrm{M}_{\mathrm{r}}=408,55$. 


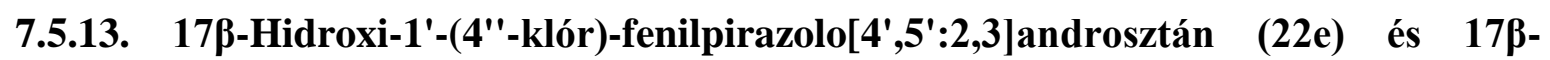
hidroxi-1'-(4' '-klór)-fenilpirazolo[4',3':2,3]androsztán (23e)

Az általános szintézismódszer szerint a 21-es kindulási anyagot és $197 \mathrm{mg} \mathbf{1 8 e}$ reagenst használtunk. Eluens: ss B. Hozam: 191 mg (45\%) 22e (fehér szilárd anyag) és 170 mg (40\%) 23e (fehér szilárd anyag). $R_{\mathrm{f}}=0,44(\mathbf{2 2 e}, \mathrm{ss} \mathrm{C})$ és $0,50(\mathbf{2 3 e}, \mathrm{ss} \mathrm{B})$.

Olvadáspont: $142-144{ }^{\circ} \mathrm{C}(\mathbf{2 2 e}), 210-213{ }^{\circ} \mathrm{C}(\mathbf{2 3 e}) ; \mathrm{C}_{26} \mathrm{H}_{33} \mathrm{ClN}_{2} \mathrm{O}, \mathrm{M}_{\mathrm{r}}=425,01$.

7.5.14. 17ß-Hidroxi-1'-(4''-bróm)-fenilpirazolo[4',5':2,3]androsztán (22f) és $17 \beta$ hidroxi-1'-(4"'-bróm)-fenilpirazolo[4',3':2,3]androsztán (23f)

Az általános szintézismódszer szerint a 21-es kindulási anyagot és $246 \mathrm{mg} \mathbf{1 8 f}$ reagenst használtunk. Eluens: ss B. Hozam: 244 mg (52\%) $22 f$ (fehér szilárd anyag) és 150 mg (32\%) $23 f$ (fehér szilárd anyag). $R_{\mathrm{f}}=0,43$ (22f, ss C) és 0,51 (23f, ss B).

Olvadáspont: $174-176{ }^{\circ} \mathrm{C}$ (22f), $237-239{ }^{\circ} \mathrm{C}(\mathbf{2 3 f}) ; \mathrm{C}_{26} \mathrm{H}_{33} \mathrm{BrN}_{2} \mathrm{O}, \mathrm{M}_{\mathrm{r}}=469,46$.

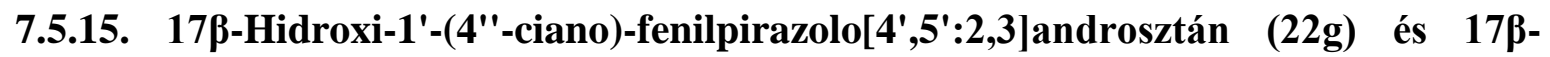
hidroxi-1'-(4' '-ciano)-fenilpirazolo[4',3':2,3]androsztán (23g)

Az általános szintézismódszer szerint a 21-es kindulási anyagot és $187 \mathrm{mg} \mathbf{1 8 g}$ reagenst használtunk. Eluens: ss B. Hozam: 83 mg (20\%) 22g (fehér szilárd anyag) és 241 mg (58\%) $\mathbf{2 3 g}$ (fehér szilárd anyag). $R_{\mathrm{f}}=0,41(\mathbf{2 2 g}$, ss C) és $0,38(\mathbf{2 3 g}, \mathrm{ss} \mathrm{B})$.

Olvadáspont: $311-314{ }^{\circ} \mathrm{C}(\mathbf{2 2 g}), 271-273{ }^{\circ} \mathrm{C}(\mathbf{2 3 g}) ; \mathrm{C}_{27} \mathrm{H}_{33} \mathrm{~N}_{3} \mathrm{O}, \mathrm{M}_{\mathrm{r}}=415,57$.

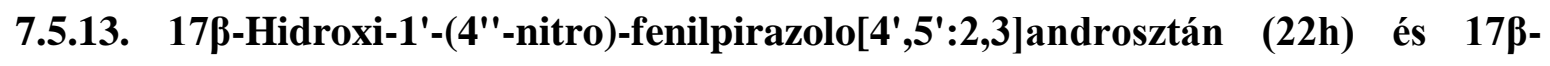
hidroxi-1'-(4'--nitro)-fenilpirazolo[4',3':2,3]androsztán (23h)

Az általános szintézismódszer szerint a 21-es kindulási anyagot és $209 \mathrm{mg} \mathbf{1 8 h}$ reagenst használtunk. Eluens: ss A. Hozam: 109 mg (25\%) 22h (narancssárga szilárd anyag) és $257 \mathrm{mg}(59 \%) \mathbf{2 3 h}$ (narancssárga szilárd anyag). $R_{\mathrm{f}}=0,31$ (22h, ss B) és 0,47 (23h, ss B). Olvadáspont: $248-251{ }^{\circ} \mathrm{C}(\mathbf{2 2 h}), 267-270{ }^{\circ} \mathrm{C}(\mathbf{2 3 h}) ; \mathrm{C}_{26} \mathrm{H}_{33} \mathrm{~N}_{3} \mathrm{O}_{3}, \mathrm{M}_{\mathrm{r}}=435,56$. 


\subsection{Szteránváz D-gyürüjéhez kondenzált 2'-arilpirimidinek előállítása (általános}

szintézismódszer)

A módszer: 1,00 mmol (316 mg) 16-hidroximetilén-androszt-5-én-3 $\beta$-ol-17-ont (17), 2,00 mmol benzaldehidet (24a, 0,20 ml) vagy 2,00 mmol p-klór-benzaldehidet (24b,

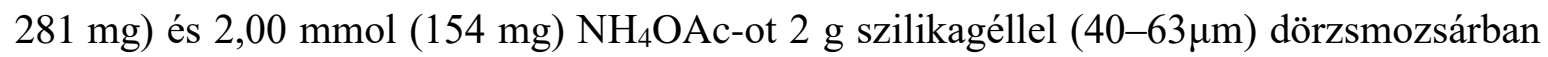
elkevertünk, majd reaktorcsőbe helyeztük és zárt rendszerben 6 percen keresztül mikrohullámmal $120^{\circ} \mathrm{C}$-on melegítettük. A reakcióelegyet feldolgozás nélkül oszlopkromatográfiával tisztítottuk EtOAc: $\mathrm{CH}_{2} \mathrm{Cl}_{2}=10: 90$ összetételü eluenssel.

$B$ módszer: 1,00 mmol (316 mg) 16-hidroximetilén-androszt-5-én-3 $\beta$-ol-17-ont (17), 2,00 mmol benzaldehidet $(\mathbf{2 4 a}, 0,20 \mathrm{ml})$ vagy 2,00 mmol $p$-klór-benzaldehidet $(\mathbf{2 4 b}$, $281 \mathrm{mg}$ ) és 2,00 mmol (154 mg) NH $4 \mathrm{OAc}$-ot $3 \mathrm{ml}$ EtOH-ban oldottunk, majd reaktorcsőbe helyeztük és zárt rendszerben 15 percen keresztül mikrohullámmal $120{ }^{\circ} \mathrm{C}$-on melegítettük. A reakcióelegyet bepároltuk és oszlopkromatográfiával tisztítottuk EtOAc: $\mathrm{CH}_{2} \mathrm{Cl}_{2}=10: 90$ összetételű eluenssel.

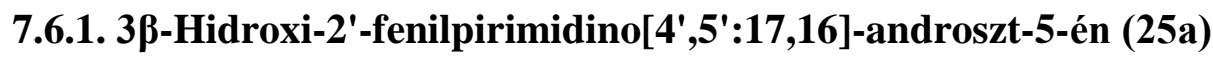

A kapott fehér szilárd termék (25a) mennyisége: $80 \mathrm{mg}$ (A módszer) vagy $124 \mathrm{mg}$ (B módszer).

$R_{\mathrm{f}}=0,35\left(\right.$ EtOAc: $\left.\mathrm{CH}_{2} \mathrm{Cl}_{2}=15: 85\right)$.

Olvadáspont: $187-187^{\circ} \mathrm{C} ; \mathrm{C}_{27} \mathrm{H}_{32} \mathrm{~N}_{2} \mathrm{O}, \mathrm{M}_{\mathrm{r}}=400,56$.

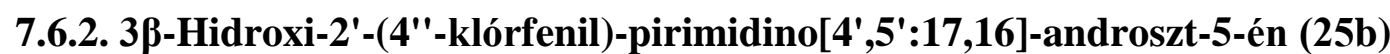

A kapott fehér szilárd termék (25b) mennyisége: 109 mg (A módszer) vagy 157 mg (B módszer).

$R_{\mathrm{f}}=0,46\left(\mathrm{EtOAc}: \mathrm{CH}_{2} \mathrm{Cl}_{2}=15: 85\right)$.

Olvadáspont: $170-173{ }^{\circ} \mathrm{C} ; \mathrm{C}_{27} \mathrm{H}_{31} \mathrm{ClN}_{2} \mathrm{O}, \mathrm{M}_{\mathrm{r}}=435,00$.

7.6. Szteránváz A-gyürüjéhez kondenzált 2'-arilpirimidinek előállítása (általános szintézismódszer)

1,00 mmol (318 mg) 2-hidroximetilén-5 $\alpha$-androszt-17 $\beta$-ol-3-ont (21) 5,00 mmol (szubsztituált) benzaldehidet (24a-i) és 5,00 mmol (386 mg) NH 40 Oc-ot $3 \mathrm{ml} \mathrm{EtOH-ban}$ oldottunk, majd reaktorcsőbe helyeztük és zárt rendszerben 15 percen keresztül 
mikrohullámmal $120^{\circ} \mathrm{C}$-on melegítettük. A reakcióelegyet bepároltuk és oszlopkromatográfiával tisztítottuk.

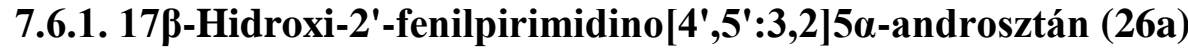

A reakcióhoz 0,51 ml 24a aldehidet használtunk. Eluens: EtOAc: $\mathrm{CH}_{2} \mathrm{Cl}_{2}=10: 90$. A kapott fehér szilárd anyag tömege: $242 \mathrm{mg}$. $R_{\mathrm{f}}=0,31\left(\mathrm{EtOAc}: \mathrm{CH}_{2} \mathrm{Cl}_{2}=15: 85\right)$. Olvadáspont: $238-241^{\circ} \mathrm{C} ; \mathrm{C}_{27} \mathrm{H}_{34} \mathrm{~N}_{2} \mathrm{O}, \mathrm{M}_{\mathrm{r}}=402,57$.

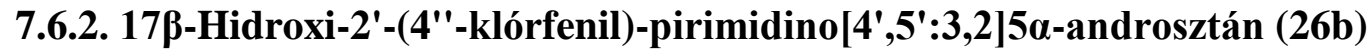

A reakcióhoz 703 mg 24b aldehidet használtunk. Eluens: EtOAc: $\mathrm{CH}_{2} \mathrm{Cl}_{2}=10: 90$. A kapott fehér szilárd anyag tömege: $271 \mathrm{mg} . R_{\mathrm{f}}=0,37$ (EtOAc: $\left.\mathrm{CH}_{2} \mathrm{Cl}_{2}=15: 85\right)$. Olvadáspont: $277-280{ }^{\circ} \mathrm{C} ; \mathrm{C}_{27} \mathrm{H}_{33} \mathrm{ClN}_{2} \mathrm{O}, \mathrm{M}_{\mathrm{r}}=437,02$.

\subsubsection{7ß-Hidroxi-2'-(4'"-brómfenil)-pirimidino[4',5':3,2]5a-androsztán (26c)}

A reakcióhoz 925 mg 24c aldehidet használtunk. Eluens: EtOAc: $\mathrm{CH}_{2} \mathrm{Cl}_{2}=10: 90$. A kapott fehér szilárd anyag tömege: $299 \mathrm{mg} . R_{\mathrm{f}}=0,38\left(\right.$ EtOAc: $\left.\mathrm{CH}_{2} \mathrm{Cl}_{2}=15: 85\right)$. Olvadáspont: $268-271^{\circ} \mathrm{C} ; \mathrm{C}_{27} \mathrm{H}_{33} \mathrm{BrN}_{2} \mathrm{O}, \mathrm{M}_{\mathrm{r}}=481,47$.

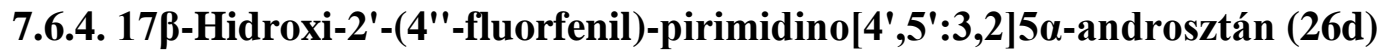

A reakcióhoz 0,54 ml 24d aldehidet használtunk. Eluens: EtOAc: $\mathrm{CH}_{2} \mathrm{Cl}_{2}=5: 95$. A kapott fehér szilárd anyag tömege: $252 \mathrm{mg}$. $R_{\mathrm{f}}=0,34\left(\right.$ EtOAc: $\left.\mathrm{CH}_{2} \mathrm{Cl}_{2}=15: 85\right)$. Olvadáspont: $247-250{ }^{\circ} \mathrm{C} ; \mathrm{C}_{27} \mathrm{H}_{33} \mathrm{FN}_{2} \mathrm{O}, \mathrm{M}_{\mathrm{r}}=420,56$.

\subsubsection{7ß-Hidroxi-2'-(4''-nitrofenil)-pirimidino $\left[4^{\prime}, 5{ }^{\prime}: 3,2\right] 5 \alpha$-androsztán (26e)}

A reakcióhoz 756 mg 24e aldehidet használtunk. Eluens: EtOAc: $\mathrm{CH}_{2} \mathrm{Cl}_{2}=10: 90$. A kapott sárga szilárd anyag tömege: $309 \mathrm{mg} . R_{\mathrm{f}}=0,39\left(\right.$ EtOAc: $\left.\mathrm{CH}_{2} \mathrm{Cl}_{2}=15: 85\right)$. Olvadáspont: $302-304{ }^{\circ} \mathrm{C} ; \mathrm{C}_{27} \mathrm{H}_{33} \mathrm{~N}_{3} \mathrm{O}_{3}, \mathrm{M}_{\mathrm{r}}=447,57$.

\subsubsection{7 $\beta$-Hidroxi-2'-(4' '-metoxifenil)-pirimidino[4',5':3,2]5 $\alpha$-androsztán (26f)}

A reakcióhoz 0,61 ml $24 f$ aldehidet használtunk. Eluens: EtOAc: $\mathrm{CH}_{2} \mathrm{Cl}_{2}=5: 95$. A kapott fehér szilárd anyag tömege: $190 \mathrm{mg}$. $R_{\mathrm{f}}=0,24\left(\right.$ EtOAc: $\left.\mathrm{CH}_{2} \mathrm{Cl}_{2}=15: 85\right)$. Olvadáspont: $250-252^{\circ} \mathrm{C} ; \mathrm{C}_{28} \mathrm{H}_{36} \mathrm{~N}_{2} \mathrm{O}_{2}, \mathrm{M}_{\mathrm{r}}=432,60$. 


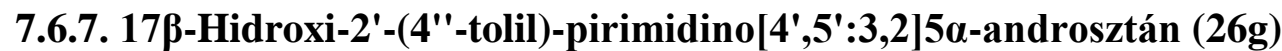

A reakcióhoz 0,59 $\mathrm{ml} \mathrm{24g}$ aldehidet használtunk. Eluens: EtOAc: $\mathrm{CH}_{2} \mathrm{Cl}_{2}=5: 95$.

A kapott fehér szilárd anyag tömege: $183 \mathrm{mg}$. $R_{\mathrm{f}}=0,34$ (EtOAc: $\left.\mathrm{CH}_{2} \mathrm{Cl}_{2}=15: 85\right)$.

Olvadáspont: $250-253{ }^{\circ} \mathrm{C} ; \mathrm{C}_{28} \mathrm{H}_{36} \mathrm{~N}_{2} \mathrm{O}, \mathrm{M}_{\mathrm{r}}=416,60$.

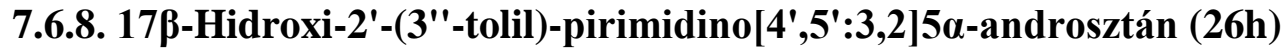

A reakcióhoz 0,59 $\mathrm{ml} \mathbf{2 4 h}$ aldehidet használtunk. Eluens: EtOAc: $\mathrm{CH}_{2} \mathrm{Cl}_{2}=5: 95$.

A kapott fehér szilárd anyag tömege: $179 \mathrm{mg} . R_{\mathrm{f}}=0,34\left(\right.$ EtOAc: $\left.\mathrm{CH}_{2} \mathrm{Cl}_{2}=15: 85\right)$.

Olvadáspont: $221-224{ }^{\circ} \mathrm{C} ; \mathrm{C}_{28} \mathrm{H}_{36} \mathrm{~N}_{2} \mathrm{O}, \mathrm{M}_{\mathrm{r}}=416,60$.

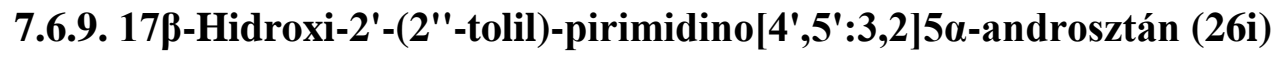

A reakcióhoz 0,58 $\mathrm{ml} \mathrm{24i}$ aldehidet használtunk. Eluens: EtOAc: $\mathrm{CH}_{2} \mathrm{Cl}_{2}=5: 95$.

A kapott fehér szilárd anyag tömege: $42 \mathrm{mg}$. $R_{\mathrm{f}}=0,27\left(\right.$ EtOAc: $\left.\mathrm{CH}_{2} \mathrm{Cl}_{2}=15: 85\right)$.

Olvadáspont: $177-180{ }^{\circ} \mathrm{C} ; \mathrm{C}_{28} \mathrm{H}_{36} \mathrm{~N}_{2} \mathrm{O}, \mathrm{M}_{\mathrm{r}}=416,60$.

7.7. Szteránváz A-gyürüjéhez kondenzált 4'-aril-3',4'-dihidropirimidin-2'(1H)-onok (27a-g) és ezek oxidációjával nyert 4'-arilpirimidin-2'(1H)-onok előállítása (28a-g) (általános szintézismódszer)

1,00 mmol (318 mg) 17 $\beta$-acetoxi-5 $\alpha$-androsztán-3-on (10), 2,00 mmol (szubsztituált) benzaldehid (24a-g) és 1,00 mmol (60 mg) karbamid $10 \mathrm{ml}$ ecetsavas elegyéhez 2 csepp cc. $\mathrm{H}_{2} \mathrm{SO}_{4}$-at adtunk. A keveréket zárt rendszerben 10 percig mikrohullámú besugárzással $110{ }^{\circ} \mathrm{C}$-on melegítettük. A reakcióelegyet $10 \mathrm{ml}$ telített $\mathrm{NaHCO}_{3}$ oldatra öntöttük, $2 \times 10 \mathrm{ml}$ $\mathrm{CH}_{2} \mathrm{Cl}_{2}$-nal extraháltuk. Az egyesített szerves fázist vízzel mostuk, izzított $\mathrm{Na}_{2} \mathrm{SO}_{4}$-on

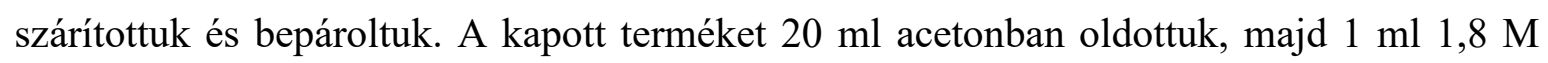
Jones-reagenst adtunk hozzá és 30 percig szobahőmérsékleten kevertük. Az elegyet ezután vízre öntöttük, $2 \times 10 \mathrm{ml} \mathrm{CH} \mathrm{Cl}_{2}$-nal extraháltuk. Az egyesített szerves fázist vízzel mostuk, izzított $\mathrm{Na}_{2} \mathrm{SO}_{4}$-on szárítottuk és bepároltuk. A nyersterméket oszlopkromatográfiával tisztítottuk $\mathrm{MeOH}: \mathrm{CH}_{2} \mathrm{Cl}_{2}=5: 95$ eluenssel. 


\subsubsection{7ß-Acetoxi-5 $\alpha$-androsztano[2,3:5',6']-4'-fenilpirimidin-2(1H)-on (28a)}

A reakcióhoz $0,2 \mathrm{ml} \mathbf{2 4 a}$ aldehidet használtunk.

A kapott fehér szilárd anyag tömege: $309 \mathrm{mg} . R_{\mathrm{f}}=0,42\left(\mathrm{MeOH}: \mathrm{CH}_{2} \mathrm{Cl}_{2}=7: 93\right)$.

Olvadáspont: $159-162{ }^{\circ} \mathrm{C} ; \mathrm{C}_{29} \mathrm{H}_{36} \mathrm{~N}_{2} \mathrm{O}_{3}, \mathrm{M}_{\mathrm{r}}=460,61$.

\subsubsection{7ß-Acetoxi-5 $\alpha$-androsztano[2,3:5',6']-4'-(4' '-klórfenil)-pirimidin-2(1H)-on} (28b)

A reakcióhoz $281 \mathrm{mg} \mathbf{2 4 b}$ aldehidet használtunk.

A kapott fehér szilárd anyag tömege: $307 \mathrm{mg}$. $R_{\mathrm{f}}=0,43\left(\mathrm{MeOH}: \mathrm{CH}_{2} \mathrm{Cl}_{2}=7: 93\right)$.

Olvadáspont: $193-196{ }^{\circ} \mathrm{C} ; \mathrm{C}_{29} \mathrm{H}_{35} \mathrm{ClN}_{2} \mathrm{O}_{3}, \mathrm{M}_{\mathrm{r}}=495,05$.

\subsubsection{7ß-Acetoxi-5 $\alpha$-androsztano[2,3:5',6']-4' -(4''-brómfenil)-pirimidin-2(1H)-on} (28c)

A reakcióhoz $370 \mathrm{mg} \mathrm{24c}$ aldehidet használtunk.

A kapott fehér szilárd anyag tömege: $334 \mathrm{mg} . R_{\mathrm{f}}=0,40\left(\mathrm{MeOH}: \mathrm{CH}_{2} \mathrm{Cl}_{2}=7: 93\right)$.

Olvadáspont: $231-234{ }^{\circ} \mathrm{C} ; \mathrm{C}_{29} \mathrm{H}_{35} \mathrm{BrN}_{2} \mathrm{O}_{3}, \mathrm{M}_{\mathrm{r}}=539,50$.

\subsubsection{7ß-Acetoxi-5 $\alpha$-androsztano[2,3:5',6']-4'-(4''-fluorfenil)-pirimidin-2(1H)-on} (28d)

A reakcióhoz 0,21 $\mathrm{ml} \mathbf{2 4 d}$ aldehidet használtunk.

A kapott fehér szilárd anyag tömege: $306 \mathrm{mg} . R_{\mathrm{f}}=0,40\left(\mathrm{MeOH}: \mathrm{CH}_{2} \mathrm{Cl}_{2}=7: 93\right)$.

Olvadáspont: $182-185^{\circ} \mathrm{C} ; \mathrm{C}_{29} \mathrm{H}_{35} \mathrm{FN}_{2} \mathrm{O}_{3}, \mathrm{M}_{\mathrm{r}}=478,60$.

\subsubsection{7ß-Acetoxi-5 $\alpha$-androsztano[2,3:5',6']-4' -(4' '-nitrofenil)-pirimidin-2(1H)-on} (28e)

A reakcióhoz 302 mg 24e aldehidet használtunk.

A kapott narancssárga szilárd anyag tömege: $349 \mathrm{mg}$. $R_{\mathrm{f}}=0,38\left(\mathrm{MeOH}: \mathrm{CH}_{2} \mathrm{Cl}_{2}=7: 93\right)$.

Olvadáspont: $209-212{ }^{\circ} \mathrm{C} ; \mathrm{C}_{29} \mathrm{H}_{35} \mathrm{~N}_{3} \mathrm{O}_{5}, \mathrm{M}_{\mathrm{r}}=505,61$. 


\subsubsection{7ß-Acetoxi-5 $\alpha$-androsztano[2,3:5',6']-4' -(4' '-metoxifenil)-pirimidin-2(1H)-on}

(28f)

A reakcióhoz 0,24 $\mathrm{ml} \mathbf{2 4 f}$ aldehidet használtunk.

A kapott fehér szilárd anyag tömege: $294 \mathrm{mg} . R_{\mathrm{f}}=0,38\left(\mathrm{MeOH}: \mathrm{CH}_{2} \mathrm{Cl}_{2}=7: 93\right)$.

Olvadáspont: $199-202{ }^{\circ} \mathrm{C} ; \mathrm{C}_{30} \mathrm{H}_{38} \mathrm{~N}_{2} \mathrm{O}_{4}, \mathrm{M}_{\mathrm{r}}=490,63$.

\subsubsection{7ß-Acetoxi-5 $\alpha$-androsztano[2,3:5',6']-4' -(4' '-tolil)-pirimidin-2(1H)-on (28g)}

A reakcióhoz $281 \mathrm{mg} \mathbf{2 4 g}$ aldehidet használtunk.

A kapott fehér szilárd anyag tömege: $299 \mathrm{mg}$. $R_{\mathrm{f}}=0,39\left(\mathrm{MeOH}: \mathrm{CH}_{2} \mathrm{Cl}_{2}=7: 93\right)$.

Olvadáspont: $231-234{ }^{\circ} \mathrm{C} ; \mathrm{C}_{30} \mathrm{H}_{38} \mathrm{~N}_{2} \mathrm{O}_{3}, \mathrm{M}_{\mathrm{r}}=474,63$.

7.8. A 28a-g származékok 17ß-hidroxi analogonjainak (29a-g) előállítása (általános szintézismódszer)

0,25 mmol 28a-g vegyületet $10 \mathrm{ml} \mathrm{MeOH-ban} \mathrm{oldottunk} \mathrm{és} 1 \mathrm{mmol}(56 \mathrm{mg}) \mathrm{KOH}$-ot adtunk hozzá. Az elegyet szobahőmérsékleten 8 órán át kevertük, majd vízre öntöttük és $\mathrm{NH}_{4} \mathrm{Cl}$-dal kisóztuk. A kivált csapadékot szürtük, vízzel semlegesre mostuk és szárítottuk.

\subsubsection{7ß-Hidroxi-5 $\alpha$-androsztano[2,3:5',6']-4'-fenilpirimidin-2(1H)-on (29a)}

A reakcióhoz 115 mg $\mathbf{2 8 a}$ vegyületet használtunk.

A kapott fehér szilárd anyag tömege: $91 \mathrm{mg}(87 \%) . R_{\mathrm{f}}=0,43\left(\mathrm{MeOH}: \mathrm{CH}_{2} \mathrm{Cl}_{2}=10: 90\right)$.

Olvadáspont: $173-176^{\circ} \mathrm{C} ; \mathrm{C}_{27} \mathrm{H}_{34} \mathrm{~N}_{2} \mathrm{O}_{2}, \mathrm{M}_{\mathrm{r}}=418,57$.

\subsubsection{7 $\beta$-Hidroxi-5 $\alpha$-androsztano[2,3:5',6']-4'-(4'"-klórfenil)-pirimidin-2(1H)-on} (29b)

A reakcióhoz 124 mg $\mathbf{2 8 b}$ vegyületet használtunk.

A kapott fehér szilárd anyag tömege: $102 \mathrm{mg}(90 \%) . R_{\mathrm{f}}=0,59\left(\mathrm{MeOH}: \mathrm{CH}_{2} \mathrm{Cl}_{2}=10: 90\right)$.

Olvadáspont: $242-245{ }^{\circ} \mathrm{C} ; \mathrm{C}_{27} \mathrm{H}_{33} \mathrm{ClN}_{2} \mathrm{O}_{2}, \mathrm{M}_{\mathrm{r}}=453,02$. 


\subsubsection{7 $\beta$-Hidroxi-5 $\alpha$-androsztano[2,3:5',6']-4'-(4''-brómfenil)-pirimidin-2(1H)-on}

(29c)

A reakcióhoz 135 mg 28c vegyületet használtunk.

A kapott fehér szilárd anyag tömege: $109 \mathrm{mg}(88 \%) . R_{\mathrm{f}}=0,44\left(\mathrm{MeOH}: \mathrm{CH}_{2} \mathrm{Cl}_{2}=10: 90\right)$. Olvadáspont: $220-222{ }^{\circ} \mathrm{C} ; \mathrm{C}_{27} \mathrm{H}_{33} \mathrm{BrN}_{2} \mathrm{O}_{2}, \mathrm{M}_{\mathrm{r}}=497,47$.

\subsubsection{7ß-Hidroxi-5 $\alpha$-androsztano[2,3:5',6']-4'-(4'"-fluorfenil)-pirimidin-2(1H)-on} (29d)

A reakcióhoz $120 \mathrm{mg}$ 28d vegyületet használtunk.

A kapott fehér szilárd anyag tömege: $100 \mathrm{mg}(92 \%) . R_{\mathrm{f}}=0,43\left(\mathrm{MeOH}: \mathrm{CH}_{2} \mathrm{Cl}_{2}=10: 90\right)$. Olvadáspont: $206-208{ }^{\circ} \mathrm{C} ; \mathrm{C}_{27} \mathrm{H}_{33} \mathrm{FN}_{2} \mathrm{O}_{2}, \mathrm{M}_{\mathrm{r}}=436,56$.

\subsubsection{7ß-Hidroxi-5 $\alpha$-androsztano[2,3:5',6']-4'-(4'"-nitrofenil)-pirimidin-2(1H)-on} (29e)

A reakcióhoz 126 mg 28e vegyületet használtunk.

A kapott sárga szilárd anyag tömege: $110 \mathrm{mg}(95 \%) . R_{\mathrm{f}}=0,44\left(\mathrm{MeOH}: \mathrm{CH}_{2} \mathrm{Cl}_{2}=10: 90\right)$. Olvadáspont: $300{ }^{\circ} \mathrm{C}$ felett bomlik; $\mathrm{C}_{27} \mathrm{H}_{33} \mathrm{~N}_{3} \mathrm{O}_{4}, \mathrm{M}_{\mathrm{r}}=463,57$.

7.8.6. 17 $\beta$-Hidroxi-5 $\alpha$-androsztano[2,3:5',6']-4'-(4'"-metoxifenil)-pirimidin-2(1H)-on (29f)

A reakcióhoz 123 mg $\mathbf{2 8 f}$ vegyületet használtunk.

A kapott fehér szilárd anyag tömege: $95 \mathrm{mg}(85 \%) . R_{\mathrm{f}}=0,40\left(\mathrm{MeOH}: \mathrm{CH}_{2} \mathrm{Cl}_{2}=10: 90\right)$. Olvadáspont: $195-198^{\circ} \mathrm{C} ; \mathrm{C}_{28} \mathrm{H}_{36} \mathrm{~N}_{2} \mathrm{O}_{3}, \mathrm{M}_{\mathrm{r}}=448,60$.

\subsubsection{7ß-Hidroxi-5 $\alpha$-androsztano[2,3:5',6']-4'-(4''-tolil)-pirimidin-2(1H)-on (29g)}

A reakcióhoz 119 mg $\mathbf{2 8 g}$ vegyületet használtunk.

A kapott fehér szilárd anyag tömege: $98 \mathrm{mg}(91 \%) . R_{\mathrm{f}}=0,40\left(\mathrm{MeOH}: \mathrm{CH}_{2} \mathrm{Cl}_{2}=10: 90\right)$. Olvadáspont: $191-194{ }^{\circ} \mathrm{C} ; \mathrm{C}_{28} \mathrm{H}_{36} \mathrm{~N}_{2} \mathrm{O}_{2}, \mathrm{M}_{\mathrm{r}}=432,60$. 


\section{8. Összefoglalás}

A doktori munkám során tett célkitüzések megvalósultak, a nemi hormon alapvázakhoz anellált nitrogéntartamú heterociklusok előállítását sikeresen végrehajtottuk.

A kísérleti munkánk első részében ösztránváz D-gyürüjéhez kondenzált kinolinszármazékok szintézisét végeztük el. A heterogyürü kialakításához szükséges kiindulási $\beta$-klórvinil-aldehidet (2) ösztron-3-metil-éterből (1) Vilsmeier-Haack reakcióval állítottuk elő. A ciklizációt első lépésben oldószermentes körülmények alkalmazásával valósítottuk meg. A mikrohullámú melegítéssel végrehajtott reakcióban a bifunkciós vegyülethez (2) anilint (4a) adtunk. A folyamat végén a VRK lapon számos nem azonosított melléktermék képződését tapasztaltunk, ezért a kísérletet DMF-ben megismételtük. Az oldószeres közegben végzett reakciók során a melléktermékek száma csökkent. A tisztítást követően az 5a származékot 53\%-os hozammal kaptuk. A szintézist elvégeztük parahelyzetben elektronküldő csoportot $\left(\mathrm{CH}_{3}, \mathrm{OMe}\right)$ tartalmazó aromás aminokkal (4b és $\left.\mathbf{4 c}\right)$ is. Mindkét esetben a kívánt heterociklusos (5b és 5c) származékokat közepes hozamokkal (47\% és 54\%) sikerült kinyerni a reakcióelegyekből. Orto-toluidin (4h) alkalmazásakor nem tapasztaltuk heterociklus képződését, ugyanakkor a para-helyzetben elektronvonzó csoportot $\left(\mathrm{Cl}, \mathrm{NO}_{2}\right)$ tartalmazó reagensek használatakor a szintézisek során a VRK alapján megfigyelhető volt a termék keletkezése, de a feldolgozási vagy a tisztítási lépések során ezek a vegyületek elbomlottak.

A szteránváz részben vagy teljesen telített A- és D-gyürüje azonos reakciókörülmények között eltérő viselkedést mutathat. Tekintettel arra, hogy az ösztránváz D-gyürüjéhez kondenzált kinolinokat (5a-c) csak közepes hozamokkal (47-54\%) kaptuk, olyan próbareakciók elvégzése mellett döntöttünk, melyekben a szteránváz hattagú A-gyürüjét 6-metoxi-tetralonnal (6) modelleztük. A Vilsmeier-Haack reakcióval elöállított nem szteroid $\beta$-klórvinil-aldehidet (7) anilinnel (4a) és szubsztituált anilinszármazékokkal (4b-f) reagáltattuk DMF-es közegben, mikrohullámú fütést alkalmazva. A kísérletek minden esetben a reagensek funkciós csoportjainak aromás gyürün elfoglalt pozíciójától és elektronigényétől függetlenül stabilis termékeket (9a-f) eredményeztek. Az aromás aminok szubsztituensei azonban befolyásolták a reakciósebességet. Az elektronküldő funkciós csoportokat $\left(\mathrm{CH}_{3}, \mathrm{OMe}\right)$ tartalmazó aromás aminok $(\mathbf{4 b}, \mathbf{4 c})$ növelték, míg az elektronvonzók $(\mathrm{Cl}, \mathrm{Br})(\mathbf{4 d}-\mathbf{f})$ csökkentették a heterociklus kialakulásának gyorsaságát az anilinnel (4a) végzett kísérlethez képest. Az orto-helyzetü szubsztiuens (4d) ciklizációra 
gyakorolt sztérikus gátlása is megfigyelhető volt, mely az alacsonyabb termékhozamban és a csökkent reakciósebességben mutatkozott meg.

A modellkísérletek során szerzett tapasztalatok alapján úgy döntöttünk, hogy a kinolin heterogyürüt az androsztánváz hattagú A-gyürüjén is kiépítjük. A bifunkciós szteroid szintéziséhez a Vilsmeier-Haack reakcióban 17 $\beta$-acetoxi-5 $\alpha$-dihidrotesztoszteront (10) használtunk kiindulási anyagként. Az ösztron-3-metil-éternél (1) illetve a 6-metoxitetralonnál (6) alkalmazott körülmények között azonban föként bisz-formilezett termék (12) keletkezését tapasztaltuk. A szintézist szobahőmérsékleten megismételve a mellékreakciót sikeresen visszaszorítottuk, és a bifunkciós szteroidot (11) jó hozammal nyertük. A $\beta$-klórvinil-aldehidet (11) ezután anilinnel (4a) és szubsztituált anilinszármazékokkal (4b-j) reagáltattuk DMF-es közegben, mikrohullámú besugárzás mellett. A szintézisek során minden esetben stabilis terméket (13a-f, 13h) kaptunk, meta-szubsztituált anilinek alkalmazásakor azonban régióizomerek keveréke (13g, 13g' és 13i, 13i') képződött. A modellkísérletekkel azonos szubsztituenshatást figyeltünk meg a szteránváz A-gyürüjéhez anellált analogonok esetén is. A 4-nitroanilin (4j) és a $\beta$-klórvinil-aldehid (11) reakciójában a kondenzált kinolingyürü kialakulása nem volt sikeres, helyette kis mennyiségben $\beta$ arilaminovinil-aldehid (15) keletkezését figyeltük meg. A tiszta formában izolált származékok lúgos közegben végzett dezacetilezési reakcióival 17ß-OH származékokat (14a-g, 14g') állítottunk elö. A kísérleti tapasztalatok alapján javaslatot tettünk a reakció mechanizmusára, mellyel jól magyarázható a régiószelektív termékképződés, és a reagensek szubsztituenseinek hatása is a gyürüzárási folyamatban.

A munka további részében szteránváz A- és D-gyürüjéhez kondenzált pirazolok szintézisét végeztük el. Utóbbi származékok kiindulási anyaga a $3 \beta$-acetoxidehidroepiandroszteronból (16) Claisen-kondenzációval előállított 16-hidroximetilénDEA (17) volt. A szintézis paramétereinek optimalizálása érdekében az 1,3-dikarbonil vegyületet (17) először a Knorr-reakció klasszikus körülményei között etanolos közegben fenilhidrazinnal (18a) reagáltattuk katalitikus mennyiségü ecetsav alkalmazásával vagy anélkül. Mindkét esetben régiószelektív termékképződést (kizárólag 19a) figyeltünk meg. A szobahőmérsékleten, savas közegben lejátszódó folyamat esetén nagyobb reakciósebességet tapasztaltunk, mint a tiszta etanolos, forralással végzett reakciónál. Az optimalizálás egyik fő célja az volt, hogy az átalakítást a kereskedelmi forgalomban kapható arilhidrazinhidrokloridokra $(\mathbf{1 8 a}-\mathbf{h} \cdot \mathrm{HCl})$ is kiterjesszük, így a szintézist fenilhidrazin-hidrokloriddal $(\mathbf{1 8 a} \cdot \mathrm{HCl})$ etanolban ekvivalens mennyiségü $\mathrm{KOH}$ vagy 0,3 ekv. $p$-TsOH hozzáadásával is 
elvégeztük. Az utóbbi körülmény alkalmazásakor a reakcióban a lehetséges régióizomerek (19a és 20a) 1:1 arányú keverékét kaptuk. Az átalakítást piridinben is végrehajtottuk, mely egyszerre szolgált bázisként a reagens sójából való felszabadításához és oldószerként is, és a folyamat során ismét csak egy termék (19a) keletkezését figyeltük meg. A továbbiakban a kiindulási bifunkciós szteroid (17) és helyettesített fenilhidrazin-hidroklorid sók (18b$\mathbf{h} \cdot \mathrm{HCl}$ ) reakcióit hajtottuk végre piridines és savas etanolos közegben. Az előbbi oldószer alkalmazásakor minden esetben régiószelektíven a 19-es izomer keletkezett. Savas etanolos közegben azonban a két lehetséges izomer (19 és 20) keverékét kaptuk, az alkalmazott reagens szubsztituensétől függő arányban. Kivételt jelentett a 4-nitro-fenilhidrazin reakciója, ahol szelektíven a 19h termék keletkezett. A ${ }^{1} \mathrm{H}-\mathrm{NMR}$ spektroszkópiával meghatározott termékarányok jól korreláltak az oszlopkromatográfiás tisztítást követő hozamokkal. A kísérleti tapasztalatok alapján javaslatot tettünk a reakció mechanizmusára a szteránváz Dgyürüjén. Az androsztánváz A-gyürüjéhez kondenzált pirazolok szintéziséhez 17ß-acetoxidihidrotesztoszteronból (10) Claisen-kondenzációval előállított 2-hidroximetilén-DHT-t (21) használtunk. A bifunkciós szteroid (21) és fenilhidrazin (18a), valamint hidrokloridjának $(\mathbf{1 8 a} \cdot \mathrm{HCl})$ reakcióját három eltérő körülmény alkalmazása mellett vizsgáltuk. Az etanolban forralással végzett szintézis esetén a D-gyürüs származékhoz (17) képest növekedett a reakciósebesség, a folyamat a korábbiakhoz hasonlóan régiószelektíven játszódott le (22a termék). A $\beta$-ketoaldehid (21) és a fenilhidrazin sójának $(\mathbf{1 8 a} \cdot \mathrm{HCl})$ szobahőmérsékleten, savas etanolos közegben vagy piridinben végzett kísérletei azonban minden esetben régióizomer párokat (22a és 23a) eredményeztek. A szintéziseket ezután mindkét körülmény mellett elvégeztük szubsztituált arilhidrazin-hidrokloridokkal (18b-h) is. Minden esetben termékkeverékek (22b-h és $\mathbf{2 3 b}-\mathbf{h})$ keletkezését figyeltük meg. Erősen elektronvonzó szubsztituenst $\left(\mathrm{CN}, \mathrm{NO}_{2}\right)$ tartalmazó reagensek (18g és $\left.18 \mathrm{~h}\right)$ használatakor a termékarány a 23-as izomer felé tolódott el, míg halogéntartalmú $(\mathrm{F}, \mathrm{Cl}, \mathrm{Br})(\mathbf{1 8 d}-\mathbf{f})$ vagy elektronküldő $\left(\mathrm{CH}_{3}, \mathrm{OMe}\right)(\mathbf{1 8 b}, \mathbf{1 8 c})$ csoportot tartalmazó arilhidrazinok nem gyakoroltak jelentős hatást a keletkező termékek eloszlására a fenilhidrazinhoz (18a) képest. A korábbival eltérö tapasztalatok alapján javaslatot tettünk a reakció mechanizmusára az androsztánváz hattagú A-gyürüjén is.

A kísérleti munka befejező részében androsztánvázhoz kondenzált pirimidinszármazékok szintézisét valósítottuk meg multikomponensű reakciókkal. A kiindulási anyagként választott 16-hidroximetilén-dehidroepiandroszteront benzaldehiddel (24a) vagy $p$-Cl-benzaldehiddel (24b) és ammónium-acetáttal, 
mikrohullámú besugárzás mellett reagáltattuk. Az első, oldószermentes szintézis során csekély termékhozamot (20-25\%) tapasztaltunk mindkét esetben, ezért etanolos közegben megismételtük a kísérletet. Az oldószer alkalmazásakor a kapott termékek mennyisége 10\%kal növekedett. Összehasonlító reakciót végeztünk benzaldehiddel (24a) $\mathrm{NH}_{4} \mathrm{OAc}$-tal és 2-hidroximetilén-dihidrotesztoszteronnal (21) etanolban, a szteránváz A-gyürüjén, mely során nagyobb mennyiségü (45\%) androsztánvázhoz kondenzált arilpirimidin (26a) keletkezését tapasztaltuk a D-gyürün végzett szintézisekhez képest. Ezután a reagensek arányát optimalizáltuk (21:24a: $\left.\mathrm{NH}_{4} \mathrm{OAc}=1: 5: 5\right)$ a maximális hozam (60\%) elérése érdekében. A továbbiakban $o$ - $(\mathbf{2 4 i}), m$ - $\mathbf{( 2 4 h )}$, és $p$-tolualdehiddel $(\mathbf{2 4 g})$ vizsgáltuk a reagensek sztérikus hatását a multikomponensű reakcióban. A kapott hozamok (10-43\%) alapján elmondható, hogy a közeli $o$ - és $m$-helyzetü funkciós csoportok nem kedvezők a ciklizációs folyamatban. Ezután vizsgáltuk a reagensek elektronikus hatását az intermolekuláris gyürüzárásra nézve. Az elektronküldő csoportot $\left(\mathrm{OMe}, \mathrm{CH}_{3}\right)$ tartalmazó származékok (24f, 24g) csökkentették (44-49\%), míg az elektronvonzó szubsztituenst (F, $\left.\mathrm{Cl}, \mathrm{Br}, \mathrm{NO}_{2}\right)$ tartalmazó aromás aldehidek (24b-e) a benzaldehiddel (24a) végzett szintézisekhez képest növelték (60-69\%) a termékek hozamát. A kísérleti tapasztalatok jól magyarázhatók voltak az általunk feltételezett reakciómechanizmussal. Androsztánváz Agyürüjéhez kondenzált pirimidinszármazékok kialakítására a Biginelli-reakció is alkalmazható. A korábbi többkomponensű kísérletek tapasztalatai miatt a reakciót a szteránváz D-gyürüjén nem végeztük el. A multikomponensü szintézis során, amelyben a bifunkciós molekularész in situ keletkezik, 17ß-acetoxi-DHT-t (10) karbamiddal és benzaldehiddel (24a) vagy $p$-szubsztituált arilaldehidekkel (24b-g) reagáltattunk. A szintézisek eredményeként a folyamatban kialakuló új aszimmetriacentrum miatt dihidropirimidinon diasztereomerek oszlopkromatográfiával nem elválasztható keverékét kaptuk, kis mennyiségü pirimidinon termék keletkezése mellett. A termékkeveréket ezért Jones-reagenssel oxidáltuk. A reakciókban tapasztalt hozamok alapján a reagens szubsztituensének jellege csekély hatást gyakorolt a gyürüzárási folyamatra. A vegyületek (28a-g) lúgos közegü (KOH/MeOH) dezacetilezésével a megfelelő 17ß-OH vegyületeket (28a-g) nyertük.

A fizikai adatok (olvadáspont, retenciós faktor) meghatározása mellett az előállított vegyületek szerkezetét nagymüszeres analitikai módszerekkel (IR, NMR, ESI-MS) igazoltuk. 
Az általunk előállított vegyületek in vitro sejtosztódásgátlási vizsgálatokra kerültek együttmüködések keretében. A farmakológiai vizsgálatokat a SZTE GYTK Gyógyszerhatástani és Biofarmáciai Intézetében, valamint a SZTE TTIK Biokémiai és Molekuláris Biológiai Tanszékén végezték el, több különböző humán daganatos sejtvonalon. A mérések során több származék antiproliferatív vagy direkt citotoxikus aktivitást mutatott. 


\section{Summary}

During my $\mathrm{PhD}$ work all our experimental objectives were achieved, and various nitrogencontaining heterocycles fused to ring $\mathrm{A}$ or $\mathrm{D}$ of the strerane core were succesfuly synthesized.

At the beginning of our research, we prepared estrone derivatives bearing a quinoline heterocycle condensed to ring D. For the preparation of $\beta$-chlorovinyl aldehyde (2) suitable for heterocycle formation, estrone 3-methyl ether (1) was used as starting material. The addition of Vilsmeier-Haack reagent $\left(\mathrm{POCl}_{3} / \mathrm{DMF}\right)$ in $\mathrm{CHCl}_{3}$ to the steroid, and subsequent reflux for $4 \mathrm{~h}$ afforded the bifunctional aldehyde (2). The microwave-assisted solvent-free reaction of 2 with aniline $(\mathbf{4 a})$ at $140{ }^{\circ} \mathrm{C}$ for 10 minutes was first attempted, but the TLC (thin layer chromatography) control indicated several by-products, which made purification difficult. The reaction was repeated in DMF. We observed less unwanted products, and after the purification process the desired fused quinoline derivative (5a) was obtained in a yield of 53\%. Similar transformations were carried out with $p$-toluidine (4b) and $p$-anisidine (4c) resulting the heterocyclic products $(\mathbf{5 b}, \mathbf{5 c})$ in moderate yields. Interestingly, $o$-toluidine was not sufficiently reactive, which suggested the steric hindrance of the ortho- $\mathrm{CH}_{3}$ substituent on the ring-closure reaction. Transformations failed with aniline derivatives containing electron withdrawing groups $(\mathrm{EWG})\left(\mathrm{Cl}, \mathrm{NO}_{2}\right)$, only certain intermediates could be detected by TLC, which underwent decomposition during the purification process.

The different behavior of rings $\mathrm{A}$ and $\mathrm{D}$ of the sterane core under identical conditions has often been observed. 6-Methoxytetralone (6) was used for further experiments as a model of ring A. Non-steroidal $\beta$-chlorovinyl aldehyde (7) was prepared similarly to the synthesis of $\mathbf{2}$ with Vilsmeier-Haack complex. The microwave-assisted reactions of $\mathbf{7}$ with aniline (4a) and substituted anilines (4b-f) in DMF at $120{ }^{\circ} \mathrm{C}$ resulted in benz $[c]$ acridine derivatives $(\mathbf{9 a}-\mathbf{f})$ in varying yields, depending on the steric and electronic character of the substituents on the aromatic moiety. Electron-donating groups (EDGs) favored, while EWGs hampered the cyclization process. Ortho-substituents also showed steric effects to the ringclosures.

These results led us to investigate the similar reactions on ring A of the androstane skeleton. Applying similar conditions to those used previously in the Vilsmeier-Haack reaction for the synthesis of bifunctional streoid derivative, the transformation of $17 \beta$ acetoxy-5 $\alpha$-dihydrotestosterone (10) resulted in an unwanted bis-formylated product (12). 
Repeating the reaction at room temperature afforded the desired $\beta$-chlorovinyl aldehide (11). This compound (11) was reacted with aniline (4a) and substituted aromatic amines (4b-i), and the observations were quite similar to the reacitons of 7 with aromatic amines. The ring A-fused quinolines were deacetylated in alkaline $\mathrm{MeOH}$ to give the $17 \beta-\mathrm{OH}$ analogs $(\mathbf{1 4 a}-$ $\left.\mathbf{h}, \mathbf{1 4} \mathbf{g}^{\prime}\right)$. The experimental findings can be explained by the reaction mechanism proposed by us.

As a continuation of our work, novel pyrazoles condensed to the sterane skeleton were synthesized via Knorr-type reactions. For the ring-closure reactions on ring D, 16-hydroxymethylenedehydroepiandrosterone (17) was synsthesized from dehydroepiandrosterone acetate (16) and ethyl formate in the presence of $\mathrm{NaOEt}$ by the Claisen condensation and subsequent acidification. During preliminary reactions, compound 17 was treated with phenylhydrazine (18a) under general Knorr conditions in ethanol in the presence or absence of acetic acid catalyst. The former reaction proved to be faster, it rapidly occurred at room temperature. Both transformations led to the regioselective formation of a single arylpyrazole (19a). Since the scope of the transformation was proposed to extend later to substituted phyenylhydrazines, which are available commercially as hydrochloride salts, the reaction of $\mathbf{1 7}$ with phenylhydrazine hydrochloride $(\mathbf{1 8 a} \cdot \mathrm{HCl})$, applying an equivalent amount of $\mathrm{KOH}$ or 0.3 equivalent of $p-\mathrm{TsOH}$ was carried out. The basic conditions proved to be regioselective, while in acidic medium we observed the formation of the two possible regioisomers (19a and 20a) in a ratio of 1:1. We also tried pyridine acting as both solvent and base in the cyclization process. The reaction of $\mathbf{1 7}$ with phenylhydrazine hydrochloride $(\mathbf{1 8 a} \cdot \mathrm{HCl})$ occurred almost immediately at room temperature. TLC monitoring showed full conversion after 5 min leading to the regioselective formation of 19a. For further studies similar reactions with 17 and $p$-substituted arylhydrazines $(\mathbf{1 8 b}-\mathbf{h})$ in both acidic EtOH and pyridine were also performed in order to investigate the possible substituent effect on the regioisomeric ratio. The transformations were found to be regioselective in pyridine at room temperature, independently of the substituents of the reagents leading to $\mathbf{1 9 b}-\mathbf{h}$ in good yields, while mixtures of regioisomers (19 and 20) were obtained in hot acidic EtOH. The ratio of the regioisomeric pairs was shifted toward the formation of $\mathbf{1 9}$ over $\mathbf{2 0}$ in case of EWGs and 20 over 19 in case of EDGs. The reaction of 17 with 4-nitrophenylhydrazine $(\mathbf{1 8 h})$ led to the regioselective formation of $\mathbf{1 9 h}$. The experimental observations on the substituent effects were explained by the proposed reaction mechanism on ring D. 
For the preparation of analogous ring A-fused pyrazole derivatives in order to compare the reactivity and regioselectivity, 2-hydroxymethylenedihydrotestosterone (21) was used as 1,3-dicarbonyl starting material. First, compound 21 was reacted with phenylhydrazine (18a) in refluxing ethanol. The regioselective transformation seemed to be faster than the similar reactions on ring D. Syntheses were also performed in pyridine and acidic ( $p$-TsOH) ethanol with phenylhydrazine hydrochloride (18a). Both reactions led to the mixture of the possible regioisomers (22a and 23a) at room temperature. Subsequently, intermolecular ring closures of 21 with different substituted arylhydrazine hydrochlorides (18b-h) were also performed in both acidic EtOH and pyridine. All transformations resulted in regioisomeric mixtures which were separated by column chromatography. The major formation of $\mathbf{2 3}$ over 22 in case of strong EWG-containing $\left(\mathrm{CN}, \mathrm{NO}_{2}\right)$ reagents $(\mathbf{1 8 g}, \mathbf{1 8 h})$ was observed. EDGs on the hydrazines did not have any significant impact on the isomeric distribution. According to the observations, the formation of ring A-fused pyrazoles followed a different reaction mechanism than that of the ring D-condensed analogues.

In the last stage of our work, steroidal pyrimidines were synthesized via multicomponent reactions. During the initial attempts, 16-hydroxymethylenedehydroepiandrosterone (17), benzaldehyde (24a) or 4-chlorobenzaldehyde (24b) and ammonium acetate were mixed (1:2:2 molar ratio) in a mortar with silica gel as solid support and was irradiated in a closed vessel with microwave at $120{ }^{\circ} \mathrm{C}$ for 6 minutes. We obtained the desired products (25a or 25b) only in 20-25\% yields. The MW-assisted reactions were repeated in EtOH using the same reactant ratios for $15 \mathrm{~min}$ resulting in a yield improvement of about $10 \%$. Next, the reactivity of ring A and D was compared. 2-Hydroxymethylene-5 $\alpha$-dihydrotestosterone was used (21) as starting material under the same reaction conditions and reagent ratios. The synthesis resulted in the product $\mathbf{2 6 a}$ in $45 \%$ yield. After optimization of the reagent ratios (steroid:aldehyde:ammonium-acetate $=1: 5: 5$ ) the yield increased to $60 \%$. Thereinafter, the syntheses of similar 2'-arylpyrimidines were carried out under the optimized conditions by using different substituted benzaldehyde derivatives $(\mathbf{2 4 b}-\mathbf{i})$ in order to investigate the steric and electronic effects of the substituens of the reagents on the yields of the desired products. The greater the distance of the group $\mathrm{R}$ from the reaction center was, the higher yield of the heterocyclic compound could be obtained. EWGs facilitated the reactions while EDGs were less favorable for the ring-closure step, which could be explained well with the proposed mechanism. 
Pyrimidine derivatives were also synthesized by Biginelli-type multicomponent reactions from $17 \beta$-acetoxy-5 $\alpha$-dihydrotestosterone $(\mathbf{1 0})$, urea and different benzaldehyde derivatives $(\mathbf{2 4 a}-\mathbf{g})$. Since previous experiments indicated the lower reactivity of ring D compared with ring $\mathrm{A}$, the synthesis of ring $\mathrm{D}$-fused derivatives was abandoned. The microwave-promoted heterocyclization was first carried out with benzaldehyde (24a), steroidal ketone (10) and urea in a molar ratio of $1: 2: 1$. After 10 min at $110{ }^{\circ} \mathrm{C}$ three main spots were observed on the TLC plate. Two of them were the inseparable mixture of dihydropyrimidine diastereomers $(27 \mathbf{a}-2 R$ and $27 \mathbf{a}-2 S)$, while the third one was a pyrimidinone derivative (28a) according to NMR measurements. We decided to apply a subsequent Jones oxidation to remove the unwanted asymmetric center. Steroidal pyrimidinone derivative (28a) was obtained in $67 \%$ yield after cromatographic purification. Substituent effects of the reagents were not observed during the multicomponent reactions. For the preparation of $17 \beta-\mathrm{OH}$ analogs, deacetylation of the steroidal 2'-arylpyrimidinones was carried out in alkaline $\mathrm{MeOH}$ to furnish 29a-g in excellent yields.

The structures of all synthesized compounds were confirmed by NMR, ESI-MS and IR measurements. Physical data (melting point, retention factor) were also determined.

The novel semi-synthetic compounds were subjected to in vitro pharmacologycal studies. Antiproliferative effects were determined in cooperation with the Department of Pharmacodynamics and Biopharmacy and the Department of Biochemistry and Molecular Biology (University of Szeged). In vitro tests on different human malignant cell lines indicated that several derivatives displayed strong cytotoxic or antiproliferative activity. 


\section{Köszönetnyilvánítás}

Ezúton szeretném kifejezni köszönetemet témavezetőmnek, Dr. Frank Éva egyetemi docensnek a doktori tanulmányaim mellett az alap- és mesterképzés során nyújtott szakmai segítségéért. Hálával tartozom neki a rengeteg elméleti és gyakorlati tanácsért és iránymutatásért, valamint a disszertációhoz szükséges publikációk elkészítésében nyújtott közremüködéséért. Köszönöm az értekezés alapos áttanulmányozását és a felmerülő problémákban nyújtott készséges segítségét.

Köszönettel tartozom Dr. Wölfling János egyetemi tanárnak a szakmai segítségéért és a lehetőségért, hogy doktori tanulmányaimat a Szerves Kémiai Tanszéken végezhettem el.

Hálás vagyok Dr. Schneider Gyula professor emeritusnak, aki a tanulmányaim során értékes elméleti és gyakorlati tanácsaival segítette elő a szakmai fejlődésemet.

Köszönettel tartozom Dr. Kovács Dórának és Dr. Mótyán Gergőnek, akik a kísérleti munkám során jelentkező akadályok elhárításában nélkülözhetetlen segítséget nyújtottak. Külön köszönet a Szteroidkémiai Kutatócsoport további munkatársainak a hasznos elméleti tanácsokért.

Az in vitro farmakológiai vizsgálatok elvégzéséért köszönetet mondok Dr. Kiricsi Mónika adjunktusnak és Dr. Zupkó István egyetemi docensnek és kutatócsoportjaiknak.

A disszertáció alapját képező közlemények, előadások és poszterek valamennyi társszerzőjének hálás vagyok a közremüködéséért.

Köszönettel tartozom a Richter Gedeon Talentum Alapítványnak a doktori tanulmányaim alatt nyújtott anyagi segítségéért. Köszönet illeti az OTKA-t (K-109107) és a GINOP-ot (2.3.2-15-2016-00038) a támogatásért.

Végül, de nem utolsó sorban szeretnék köszönetet mondani családomnak, kedvesemnek és barátaimnak a sok szeretetért, támogatásért, melyet egyetemi éveim és doktori tanulmányaim alatt nyújtottak, és nyújtanak nekem mind a mai napig. 


\section{Felhasznált irodalmak}

1. Zeelen, F. J. Princ. Med. Biol. 1997, 8, 427.

2. Herington, A. C.; Chopin, L. K.; Jeffery, P.; de Amorim, L.; Veveris-Lowe, T.; Bui, L.; Clements, J. A. AsPac J. Mol. Biol. Biotechnol. 2010, 18, 63.

3. Fu, X. D.; Russo, E.; Zullino, S.; Genazzani, A. R.; Simoncini, T. Horm. Mol. Biol. Clin. Invest. 2010, 3, 383.

4. Levesque, E.; Huang, S. P.; Audet-Walsh, E.; Lacombe, L.; Bao, B. Y.; Fradet, Y.; Laverdiere, I.; Rouleau, M.; Huang, C. Y.; Yu, C. C.; Caron, P.; Guillemette, C. Clin. Cancer Res. 2013, 19, 699.

5. Zhu, N.; Ling, Y.; Lei, X.; Handratta, V.; Brodie, A. M. H. Steroids 2003, 68, 603.

6. Ondré, D.; Wölfling, J.; Tóth, I.; Szécsi, M.; Julesz, J.; Schneider, Gy. Steroids 2009, $74,1025$.

7. Yadav, M. R.; Sabale, P. M.; Giridhar, R.; Zimmer, C.; Haupenthal, J.; Hartmann, R. W. Steroids 2011, 76, 464.

8. Cham, B. E. Res. J. Biol. Sci. 2007, 2, 503.

9. Liu, M. J.; Wang, Z.; Ju, Y.; Wong, R. N.; Wu, Q. Y. Cancer Chemother. Pharmacol. 2005, 55, 79 .

10. Frank, É.; Mucsi, Z.; Zupkó, I.; Réthy, B.; Falkay, G.; Schneider, Gy.; Wölfling, J. J. Am. Chem. Soc. 2009, 131, 3894.

11. Mótyán, G.; Baji, Á.; Zupkó, I.; Frank, É. J. Mol. Struct. 2016, 1110, 143.

12. Kádár, Z.; Baji, Á.; Zupkó, I.; Wölfling, J.; Frank, É. Org. Biomol. Chem. 2011, 9, 8051.

13. Kádár, Z.; Kovács, D.; Frank, É.; Schneider, Gy.; Huber, J.; Zupkó, I.; Bartók, T.; Wölfling, J. Molecules 2011, 16, 4786.

14. Kádár, Z.; Molnár, J.; Schneider, Gy.; Zupkó, I.; Frank, É. Bioorg. Med. Chem. 2012, 20, 1396.

15. Frank, É.; Kovács, D.; Schneider, Gy.; Wölfling, J.; Bartók, T.; Zupkó, I. Mol. Divers. 2014, $18,521$.

16. Wölfling, J.; Mernyák, E.; Frank, É.; Falkay, G.; Márki, Á.; Minorics, R.; Schneider, Gy. Steroids 2003, 68, 277.

17. Frank, É.; Wölfling, J.; Aukszi, B.; König, V.; Schneider, Gy. Tetrahedron 2002, 58, 6843.

18. Frank, É.; Schneider, Gy.; Kádár, Z.; Wölfling, J. Eur. J. Org. Chem. 2009, 21, 3544. 
19. Schönecker, B.; Lange, C.; Kötteritzsch, M.; Günther, W.; Weston, J.; Anders, E.; Görls, H. J. Org. Chem. 2000, 65, 5487.

20. Huang, Y.; Yang, C.; Zhan, J.; Gan, C.; Liu, Z.; Pang, C.; Chen, H.; Cui, J. Tetrahedron Lett. 2017, 58, 2952.

21. Stulov, S. V.; Misharin, A. Yu. Chem. Heterocycl. Comp. 2013, 48, 1431.

22. Rivera, D. G.; Peseke, K.; Jomarrón, I.; Montero, A.; Molina, R.; Coll, F. Molecules 2003, 8,444 .

23. Mernyák, E.; Kozma, E.; Hetényi, A.; Márk, L.; Schneider, Gy.; Wölfling, J. Steroids 2009, 74, 520 .

24. Jianguo, C.; Liang, L.; Chunfang, G.; Qi, X.; Yanmin, H. Progr. Chem. 2014, 26, 320.

25. Kerru, N.; Singh, P.; Koorbanally, N.; Raj, R.; Kumar, V. Eur. J. Med. Chem. 2017 $142,179$.

26. Balogh, J.; Skoda-Földes, R.; Vazdar, K.; Habuš, I. J. Organomet. Chem. 2012, 703, 51.

27. Singh, R.; Panda, G. Tetrahedron 2013, 69, 2853.

28. Decker, M. Curr. Med. Chem. 2011, 18, 1464.

29. Mótyán, G.; Zupkó, I.; Minorics, R.; Schneider, Gy.; Wölfling, J.; Frank, É. Mol. Divers. 2015, 19, 511.

30. Abdalla, M. M.; Al-Omar, M. A.; Bhat, M. A.; Amr, A. G. E.; Al-Mohizea, A. M.; Int. J. Biol. Macromol. 2012, 50, 1127.

31. Laitonjam, W. S.; Rajkumar, T. S.; Chingakham, B. S. Steroids 2002, 67, 203.

32. Camoutsis, C. J. Heterocycl. Chem. 1996, 33, 539.

33. Frank, É.; Mucsi, Z.; Szécsi, M.; Zupkó, I.; Wölfling J.; Schneider, Gy. New J. Chem. 2010, 34, 2671.

34. Mótyán, G.; Kádár, Z.; Kovács, D.; Wölfling J.; Frank, É. Steroids 2014, 87, 76.

35. Zhang, B.-L.; Zhang, E.; Pang, L.-P.; Song, L.-X.; Li, Y.-F.; Yu B.; Liu, H.-M. Steroids 2013, 78, 1200.

36. Yan, J. Z.; Li, J.; Rao, G. W. Steroids 2007, 72, 736.

37. Wang, C.; Xu, H.; Xie, Z.; Wang, X.; Zhang Z.; Sun, Q. Steroids 2010, 75, 1033.

38. Huang, L. H.; Zheng, Y. F.; Song, C. J.; Wang, Y. G.; Xie, Z. Y.; Lai, Y. W.; Lu Y. Z.; Liu, H. M. Steroids 2012, 77, 367.

39. Sakač, M. N.; Gakovic, A. R.; Csanádi, J. J.; Djurendić, E. A.; Klisurić, O.; Kojić, V.; Bogdanović, G.; Penov Gaši, K. M. Tetrahedron Lett. 2009, 50, 4107. 
40. Latta, K.; Krieg, R. G.; Hisano, S.; Veldhuis, J. D.; Chan, J. C. M. Eur. J. Endocrinol. 1999, $140,441$.

41. Amr, A.-G. E.; Abdulla, M. M. Bioorg. Med. Chem. 2006, 14, 4341.

42. Abdelhalim, M. M.; El-Saidi, M. M. T.; Rabie, S. T.; Elmegeed, G. A. Steroids 2007, $72,459$.

43. Afzal, O.; Kumar, S.; Haider, R.; Ali, R.; Kumar, R.; Jaggi, M.; Bawa, S. Eur. J. Med. Chem. 2015, 97, 871.

44. Borsche, W.; Frank, R. Ber. Dtsch. Chem.Ges. 1924, 57, 1373.

45. Hassner, A.; Haddadin, M. J. Org. Chem. 1962, 27, 1911.

46. Skraup, Z. H. Ber. Dtsch. Chem.Ges. 1880, 13, 2086.

47. Prajapati, S. M.; Patel, K. D.; Vekariya, R. H.; Panchal, S. N.; Patel, H. D. RSC Adv. 2014, 4, 24463.

48. Gould, R. G.; Jacobs, W. A. J. Am. Chem. Soc. 1939, 61, 2890.

49. Doebner, O.; Miller, W. Ber. Dtsch. Chem. Ges. 1881, 14,2812.

50. Yamashkin, S. A.; Oreshkina, E. A. Chem. Heterocycl. Compd. 2006, 42, 701.

51. Combes, A. Bull. Soc. Chim. Fr. 1888, 49, 89.

52. Yamashkin, S.A.; Yudin, L.G.; Kost, A.N. Chem. Heterocycl. Compd. 1992, 28, 845.

53. Conrad, M.; Limpach, L. Ber. Dtsch. Chem. Ges. 1887, 20, 944.

54. Doebner, O. Liebigs Ann. 1887, 242, 265.

55. Vilsmeier, A.; Haack, A. Ber. Dtsch. Chem. Ges. 1927, 60, 119.

56. Rajput, A. P.; Girase, P. D. Int. J. Pharm. Chem. Biol. Sci. 2012, 3, 25.

57. Kumar, N. R.; Suresh, T.; Dhanabal, T.; Mohan, P. S. Indian J. Chem. 2004, 43B, 846.

58. Marson, C. M. Tetrahedron 1992, 48, 3659.

59. Sekhar, B. C.; Ramadas, S. R.; Ramana, D. V. Heterocycles 2000, 53, 741.

60. Soibgui, A.; Gaucher, A.; Marrot, J.; Bourdreux, F.; Aloui, F.; Hassine, B. B.; Prim, D. Tetrahedron 2014, 70, 3042.

61. Siddiqui, A. U.; Rao, V. U. M.; Maimirani, M.; Siddiqui, A. H. J. Heterocycl. Chem. 1995, 32, 353.

62. Karthikeyan, P.; Rani, A. M.; Saiganesh, R.; Balasubramanian, K. K.; Kabilan, S. Tetrahedron 2009, 65, 811.

63. Gogoi, S.; Shekarrao, K.; Duarah, A.; Bora, T. C.; Gogoi S.; Boruah, R. C. Steroids 2012, 77, 1438.

64. Hesse, S.; Kirsch, G. Tetrahedron 2005, 61, 6534.

65. Some, S.; Ray, J. K. Tetrahedron Lett. 2007, 48, 5013. 
66. Cho, C. S.; Kim, H. B.; Ren W. X.; Yoon, N. S. Appl. Organomet. Chem. 2010, 24, 817.

67. Prasad, K. R.; Darbarwar, M. Org. Prep. Proced. Int. 1995, 27, 547.

68. Shekarrao, K.; Kaishap, P. P.; Saddanapu, V.; Addlagatta, A.; Gogoi, S.; Boruah, R. C. RSC Adv. 2014, 4, 24001.

69. Kosuge, T.; Okeda, H. J. Biochem. 1954, 41, 183.

70. Kosuge, T.; Okeda, H.; J. Pharm. Soc. Jap. 1954, 74, 1086.

71. Liu, X. H.; Cui, P.; Song, B. A.; Bhadury, P. S.; Zhu, H. L.; Wang, S. F. Bioorg. Med. Chem. 2008, 16, 4075.

72. Menozzi, G.; Mosti, L.; Schenone, P.; D'Amico, M.; Falciani, M.; Filippelli, W. Farmaco 1994, 49, 115.

73. Bailey, D. M.; Hansen, P. E.; Hlavac, A. G.; Baizman, E. R.; Pearl, J.; DeFelice, A. F.; Feigenson, M. E. J. Med. Chem. 1985, 28, 256.

74. Ansari, A.; Ali, A.; Asif, M.; Shamsuzzaman New J. Chem. 2017, 41, 16.

75. Khan, M. F.; Alam, M. M.; Verma, G.; Akhtar, W.; Akhter, M.; Shaquiquzzaman, M. Eur. J. Med. Chem. 2016, 120, 170.

76. Knorr, L. Ber. Dtsch. Chem. Ges. 1883, 16, 2597.

77. von Pechmann, H. Ber. Dtsch. Chem. Ges. 1898, 31, 2950.

78. Wu, L.-L.; Ge, Y.-C.; He, T.; Zhang, L.; Fu, X.-L.; Fu, H.-Y.; Chen, H.; Li, R.-X. Synthesis 2012, 44, 1577.

79. Zhang, X.; Kang, J.; Niu, P.; Wu, J.; Yu, W.; Chang, J. J. Org. Chem. 2014, 79, 10170.

80. Knorr, L. Ber. Dtsch. Chem. Ges. 1884, 17, 2756.

81. Singh, S. P.; Kumar, D.; Batra, H.; Naithani, R.; Rozas, I.; Elguero, J. Can. J. Chem. 2000, 78, 1109 .

82. Selivanov, S. I.; Bogatkin, R. A.; Ershov, B. A. Russ. J. Org. Chem. 1981, 17, 886.

83. Sloop, J. C.; Lechner, B.; Washington, G.; Bumgardner, C. L.; Loehle, W. D.; Creasy, W.; Int. J. Chem. Kinetics 2008, 40, 370.

84. Song, H.; Lee, H.; Kim, J.; Park, S. B. ACS Comb. Sci. 2012, 14, 66.

85. Ferrari, E.; Saladini, M.; Pignedoli, F.; Spagnolo, F.; Benassi, R. New J. Chem. 2011, 35,2840 .

86. Bertolasi, V.; Ferretti, V.; Gilli, P.; Yao, X.; Li, C-J. New J. Chem. 2008, 32, 694.

87. Iványi, Z.; Wölfling, J.; Görbe, T.; Szécsi, M.; Wittmann, T.; Schneider, Gy. Steroids 2010, 75, 450. 
88. Iványi, Z.; Szabó, N.; Wölfling, J.; Szécsi, M.; Julesz, J.; Schneider, Gy. Steroids, 2012, 77, 1152.

89. Wölfling, J.; Szájli, Á. Monatsh. Chem. 2006, 137, 1431.

90. Liu, H. S.; Zheng, H. L.; Ge, M.; Xia, P.; Chen, Y.; Chinese Chem. Lett. 2011, 22, 757.

91. Selvan, T. P.; James, C. R.; Dniandev, P. V.; Valzira, S. K. Res. Pharm. 2012, $24,1$.

92. Baumann, M.; Baxendale, I. R. Beilstein J. Org. Chem. 2013, 9, 2265.

93. Singh, K.; Kaur, T. Med. Chem. Comm. 2016, 7, 749.

94. Grimaux, E. C.R. Hebd. Acad. Sci. 1879, 88,85.

95. Pinner, A. Ber. Dtsch. Chem. Ges. 1884, 17, 2519.

96. Movassaghi, M.; Hill, M. D. Chem. Eur. J. 2008, 14, 6836.

97. Roopan, S. M.; Sompalle, R. Synth. Comm. 2016, 46, 645.

98. Forgó, P.; Vincze, I. Steroids 2002, 67, 749.

99. Saikia, P.; Gogoi, S.; Boruah, R. C. Tetrahedron Lett. 2015, 56, 2106.

100. Singh, M. S.; Chowdhury, S. RSC Adv. 2012, 2, 4547.

101. Rotstein, B. H.; Zaretsky, S.; Rai, V.; Yudin, A. K. Chem. Rev. 2014, 114, 8323.

102. Barthakur, G. M.; Gogoi, S.; Dutta, M.; Boruah, R. C. Steroids 2009, 74, 730.

103. Biginelli, P. Ber. Dtsch. Chem. Ges. 1891, 24, 1317.

104. Biginelli, P. Ber. Dtsch. Chem. Ges. 1891, 24, 2962.

105. Sandhu, S.; Sandhu, J. S. ARKIVOC 2012, 66.

106. Alvim, H. G. O.; da Silva, E. N.; Neto, B. A. D RSC Adv. 2014, 4, 54282.

107. Nagarajaiah, H.; Mukhopadhyay, A.; Moorthy, J. N. Tetrahedron Lett. 2016, 57, 5135.

108. Sweet, F.; Fissekis, J. D. J. Am. Chem. Soc. 1973, 95, 8741.

109. Kappe, C. O. J. Org. Chem. 1997, 62, 7201.

110. Baji, Á.; Gyovai, A.; Wölfling, J.; Minorics, R.; Ocsovszki, I.; Zupkó, I.; Frank, É. RSC Adv. 2016, 6, 27501.

111. Pan, J.; Wang, X.; Zhang, Y.; Buchwald, S. L. Org. Lett. 2011, 13, 4974.

112. Bera, R.; Dhananjaya, G.; Singh, S. N.; Ramu, B.; Kiran, S. U.; Kumar, P. R.; Mukkanti, K.; Pal, M. Tetrahedron 2008, 64, 582.

113. LaFrate, A. L.; Gunther, J. R.; Carlson, K. E.; Katzenellenbogen, J. A. Bioorg. Med. Chem. 2008, 16, 10075.

114. Lilienkampf, A.; Johansson, M. P.; Wähälä, K. Org. Lett. 2003, 5, 3387.

115. Hara, O.; Isao, S.; Eiichi, H.; Saji, S.; Kimura, M.; Ono, T. Patent WO2012026316 A1. 
116. Jones, G.; Stanforth, S. P. Organic Reactions (szerk: Overman, L. E.) 2000, 56.

117. Gagan, J. M. F.; Lloyd, D. J. Chem. Soc. 1970, 2488.

118. Baji, Á.; Kovács, F.; Mótyán, G.; Schneider, Gy.; Wölfling, J.; Sinka, I.; Zupkó, I.; Ocsovszki, I.; Frank, É. Steroids 2017, 126, 35.

119. Huang, Y.; Liu, M.; Meng, L.; Feng, P.; Guo, Y.; Ying, M.; Zhu, X.; Chen, Y. Steroids 2015, 101,7 .

120. Oda, T.; Sato, R.; Sato, Y. Chem. Pharm. Bull. 1989, 37, 502.

121. Christiansen, R. G.; Bell, M. R.; D’Ambra, T. E.; Mallamo, J. P.; Herrmann, J. L.; Ackerman, J. H.; Opalka, C. J.; Kullnig, R. K.; Winneker, R. C.; Snyder, B. W.; Batzold, F. H.; Schane, H. P. J. Med. Chem. 1990, 33, 2094.

122. Fischer, D. S.; Allan, G. M.; Bubert, C.; Vicker, N.; Smith, A.; Tutill, H. J.; Purohit, A.; Wood, L.; Packham, G.; Mahon, M. F.; Reed, M. J.; Potter, B. V. L. J. Med. Chem. 2005, 48,5749 .

123. Longin, O.; Černý, I.; Drašar, P. Steroids 2015, 97, 67.

124. Doorenbos, N. J.; Milewich, L. J. Org. Chem. 1966, 31, 3193.

125. Clinton, R. O.; Manson, A. J.; Stonner, F. W.; Neumann, H. C.; Christiansen, R. G.; Clarke, R. L.; Ackerman, J. H.; Page, D. F.; Dean, J. W.; Dickinson, W. B.; Carabates, C. J. Am. Chem. Soc. 1961, 83, 1478.

126. Baji, Á.; Kiss, T.; Wölfling, J.; Kovács, D.; Igaz, N.; Gopisetty, M. K.; Kiricsi, M.; Frank, É. J. Steroid Biochem. Mol. Biol. 2017, 172, 79.

127. Mossmann T. J. Immunol. Methods 1983, 65, 55. 


\section{Melléklet}

Az előállított vegyületek NMR, IR és MS adatai

2: ${ }^{1} \mathrm{H}$ NMR (500 MHz, $\left.\mathrm{CDCl}_{3}\right): \delta_{\mathrm{H}}=1.00\left(\mathrm{~s}, 3 \mathrm{H}, 18-\mathrm{CH}_{3}\right), 1.44(\mathrm{~m}, 1 \mathrm{H}), 1.57-1.68$ (átfedő $\mathrm{m}, 3 \mathrm{H}), 1.74(\mathrm{~m}, 1 \mathrm{H}), 1.95(\mathrm{~m}, 1 \mathrm{H}), 2.00(\mathrm{~m}, 1 \mathrm{H}), 2.16(\mathrm{~m}, 1 \mathrm{H}), 2.32(\mathrm{~m}, 1 \mathrm{H}), 2.46(\mathrm{~m}, 1 \mathrm{H})$, $2.65(\mathrm{dd}, 1 \mathrm{H}, J=14.7 \mathrm{~Hz}, J=6.4 \mathrm{~Hz}), 2.90\left(\mathrm{~m}, 2 \mathrm{H}, 6-\mathrm{CH}_{2}\right), 3.78$ (s, 3H, 3-OMe), 6.65 (d, $1 \mathrm{H}, J=2.1 \mathrm{~Hz}, 4-\mathrm{H}), 6.73(\mathrm{dd}, 1 \mathrm{H}, J=8.5 \mathrm{~Hz}, J=2.1 \mathrm{~Hz}, 2-\mathrm{H}), 7.19(\mathrm{~d}, 1 \mathrm{H}, J=8.5 \mathrm{~Hz}, 1-$ $\mathrm{H}), 10.02(\mathrm{~s}, 1 \mathrm{H}, 16-\mathrm{COH}) ;{ }^{13} \mathrm{C} \mathrm{NMR}\left(125 \mathrm{MHz}, \mathrm{CDCl}_{3}\right): \delta_{\mathrm{C}}=15.2(\mathrm{C}-18), 25.9\left(\mathrm{CH}_{2}\right)$, $27.0\left(\mathrm{CH}_{2}\right), 28.2\left(\mathrm{CH}_{2}\right), 29.5\left(\mathrm{CH}_{2}\right), 33.0\left(\mathrm{CH}_{2}\right), 37.2(\mathrm{CH}), 44.0(\mathrm{CH}), 51.0(\mathrm{C}-13), 53.0$ (CH), 55.2 (3-OMe), 111.6 (C-2), 113.8 (C-4), 125.9 (C-1), 131.8 (C-10), 136.4 (C-16), 137.7 (C-5), 157.6 (C-3), 162.4 (C-17), 188.0 (16-COH); ESI-MS: $331[\mathrm{M}+\mathrm{H}]^{+}$; $\mathrm{C}_{20} \mathrm{H}_{23} \mathrm{ClO}_{2}$.

5a: ${ }^{1} \mathrm{H}$ NMR (500 MHz, $\left.\mathrm{CDCl}_{3}\right): \delta_{\mathrm{H}}=1.10\left(\mathrm{~s}, 3 \mathrm{H}, 18-\mathrm{CH}_{3}\right), 1.55(\mathrm{~m}, 1 \mathrm{H}), 1.74-1.94$ (átfedő $\mathrm{m}, 4 \mathrm{H}), 2.08(\mathrm{~m}, 1 \mathrm{H}), 2.40(\mathrm{~m}, 1 \mathrm{H}), 2.55(\mathrm{~m}, 2 \mathrm{H}), 2.74(\mathrm{~m}, 1 \mathrm{H}), 2.98(\mathrm{~m}, 3 \mathrm{H}), 3.80(\mathrm{~s}, 3 \mathrm{H}$, 3-OMe), 6.69 (d, 1H, $J=2.4 \mathrm{~Hz}, 4-\mathrm{H}), 6.76(\mathrm{dd}, 1 \mathrm{H}, J=8.5 \mathrm{~Hz}, J=2.4 \mathrm{~Hz}, 2-\mathrm{H}), 7.28$ (d, $1 \mathrm{H}, J=8.5 \mathrm{~Hz}, 1-\mathrm{H}), 7.46$ (t-szerü m, 1H, 6'-H), 7.63 (t-szerü m, 1H, 7'-H), 7.74 (d, 1H, $J$ $\left.=7.9 \mathrm{~Hz}, 5^{\prime}-\mathrm{H}\right), 7.91\left(\mathrm{~s}, 1 \mathrm{H}, 4^{\prime}-\mathrm{H}\right), 8.10\left(\mathrm{~d}, 1 \mathrm{H}, J=8.4 \mathrm{~Hz}, 8^{\prime}-\mathrm{H}\right) ;{ }^{13} \mathrm{C}$ NMR $(125 \mathrm{MHz}$, $\left.\mathrm{CDCl}_{3}\right): \delta_{\mathrm{C}}=17.7(\mathrm{C}-18), 26.4\left(\mathrm{CH}_{2}\right), 27.5\left(\mathrm{CH}_{2}\right), 29.7\left(\mathrm{CH}_{2}\right), 30.0\left(\mathrm{CH}_{2}\right), 33.8\left(\mathrm{CH}_{2}\right), 37.9$ $(\mathrm{CH}), 44.3(\mathrm{CH}), 46.1(\mathrm{C}-13), 54.6(\mathrm{CH}), 55.2$ (3-OMe), $111.5(\mathrm{C}-2), 113.9(\mathrm{C}-4), 125.4(\mathrm{C}-$ $\left.6^{\prime}\right), 126.2$ (C-1), 127.5 (C-4a'), 127.6, 128.2 és 128.9 (C-5', C-7' és C-8'), 131.0 (C-4'), 132.5 (C-10), 134.9 (C-3'), 137.7 (C-5), 147.3 (C-8a'), 157.5 (C-3), 174.4 (C-2'); ESI-MS: 370 $[\mathrm{M}+\mathrm{H}]^{+} ; \mathrm{C}_{26} \mathrm{H}_{27} \mathrm{NO}$.

5b: ${ }^{1} \mathrm{H}$ NMR $\left(500 \mathrm{MHz}, \mathrm{CDCl}_{3}\right)$ : $\delta_{\mathrm{H}}=1.09\left(\mathrm{~s}, 3 \mathrm{H}, 18-\mathrm{CH}_{3}\right), 1.54(\mathrm{~m}, 1 \mathrm{H}), 1.72-1.92$ (átfedő $\mathrm{m}, 4 \mathrm{H}), 2.06(\mathrm{~m}, 1 \mathrm{H}), 2.38(\mathrm{~m}, 1 \mathrm{H}), 2.51\left(\mathrm{~s}, 3 \mathrm{H}, 6^{\prime}-\mathrm{CH}_{3}\right), 2.53(\mathrm{~m}, 1 \mathrm{H}), 2.58(\mathrm{~m}, 1 \mathrm{H}), 2.72$ (m, 1H), 2.97 (m, 3H), 3.80 (s, 3H, 3-OMe), 6.68 (d, 1H, J = 2.4 Hz, 4-H), 6.75 (dd, 1H, $J$ $=8.4 \mathrm{~Hz}, J=2.4 \mathrm{~Hz}, 2-\mathrm{H}), 7.28(\mathrm{~d}, 1 \mathrm{H}, J=8.5 \mathrm{~Hz}, 1-\mathrm{H}), 7.46\left(\mathrm{~d}, 1 \mathrm{H}, J=8.3 \mathrm{~Hz}, 7^{\prime}-\mathrm{H}\right), 7.50$ (s, 1H, 5'-H), 7.83 (s, 1H, 4'-H), 8.03 (d, 1H, J=8.3 Hz, 8'-H); $\left.{ }^{13} \mathrm{C} \mathrm{NMR} \mathrm{(125} \mathrm{MHz,} \mathrm{CDCl}_{3}\right)$ : $\delta_{\mathrm{C}}=17.6(\mathrm{C}-18), 21.4\left(6^{\prime}-\mathrm{CH}_{3}\right), 26.4\left(\mathrm{CH}_{2}\right), 27.4\left(\mathrm{CH}_{2}\right), 29.7\left(\mathrm{CH}_{2}\right), 29.9\left(\mathrm{CH}_{2}\right), 33.8\left(\mathrm{CH}_{2}\right)$, $37.8(\mathrm{CH}), 44.3(\mathrm{CH}), 46.0(\mathrm{C}-13), 54.6(\mathrm{CH}), 55.2$ (3-OMe), $111.5(\mathrm{C}-2), 113.9(\mathrm{C}-4), 126.2$ (C-1), $126.5\left(\mathrm{C}-5^{\prime}\right), 127.6\left(\mathrm{C}^{\prime}-4 \mathrm{a}^{\prime}\right), 128.2,130.5$ és 130.8 (C-4', C-7' és C-8'), 132.5 (C-10), 134.9 (2C, C-3' és C-6'), 135.9 (C-8a'), 137.7 (C-5), 157.5 (C-3), 174.4 (C-2'); ESI-MS: 384 $[\mathrm{M}+\mathrm{H}]^{+} ; \mathrm{C}_{27} \mathrm{H}_{29} \mathrm{NO}$.

5c: ${ }^{1} \mathrm{H}$ NMR $\left(500 \mathrm{MHz}, \mathrm{CDCl}_{3}\right): \delta_{\mathrm{H}}=1.08\left(\mathrm{~s}, 3 \mathrm{H}, 18-\mathrm{CH}_{3}\right), 1.54(\mathrm{~m}, 1 \mathrm{H}), 1.72-1.91$ (átfedő $\mathrm{m}, 4 \mathrm{H}), 2.06(\mathrm{~m}, 1 \mathrm{H}), 2.38(\mathrm{~m}, 1 \mathrm{H}), 2.55(\mathrm{~m}, 2 \mathrm{H}), 2.72(\mathrm{~m}, 1 \mathrm{H}), 2.96(\mathrm{~m}, 3 \mathrm{H}), 3.79(\mathrm{~s}, 3 \mathrm{H}$, 3-OMe), 3.91 (s, 3H, 6'-OMe), 6.68 (d, 1H, $J=2.4 \mathrm{~Hz}, 4-\mathrm{H}), 6.75$ (dd, 1H, $J=8.4 \mathrm{~Hz}, J=$ $2.4 \mathrm{~Hz}, 2-\mathrm{H}), 7.03\left(\mathrm{~s}, 1 \mathrm{H}, 4^{\prime}-\mathrm{H}\right), 7.28(\mathrm{~d}, 1 \mathrm{H}, J=8.5 \mathrm{~Hz}, 1-\mathrm{H}), 7.28(\mathrm{dd}, 1 \mathrm{H}, J=8.7 \mathrm{~Hz}, J=$ $\left.2.6 \mathrm{~Hz}, 7^{\prime}-\mathrm{H}\right), 7.83\left(\mathrm{~s}, 1 \mathrm{H}, 5^{\prime}-\mathrm{H}\right), 8.03\left(\mathrm{~d}, 1 \mathrm{H}, J=8.7 \mathrm{~Hz}, 8^{\prime}-\mathrm{H}\right) ;{ }^{13} \mathrm{C} \mathrm{NMR}\left(125 \mathrm{MHz}, \mathrm{CDCl}_{3}\right)$ : $\delta_{\mathrm{C}}=17.7(\mathrm{C}-18), 26.3\left(\mathrm{CH}_{2}\right), 27.4\left(\mathrm{CH}_{2}\right), 29.7\left(\mathrm{CH}_{2}\right), 30.0\left(\mathrm{CH}_{2}\right), 33.8\left(\mathrm{CH}_{2}\right), 37.8(\mathrm{CH})$, $44.3(\mathrm{CH}), 45.9(\mathrm{C}-13), 54.7(\mathrm{CH}), 55.2$ (3-OMe), 55.5 (6'-OMe), $105.9\left(\mathrm{C}-5{ }^{\prime}\right), 111.4(\mathrm{C}-2)$, 113.9 (C-4), 120.2 (C-7'), 126.2 (C-1), 128.5 (2C, C-3' és C-4a' ), 129.9 és 130.4 (C-4' és C- 
8'), 132.5 (C-10), $135.3\left(\mathrm{C}-8 \mathrm{a}^{\prime}\right), 137.7$ (C-5), 157.1 (C-3), 157.5 (C-6'), 171.9 (C-2'); ESIMS: $400[\mathrm{M}+\mathrm{H}]^{+} ; \mathrm{C}_{27} \mathrm{H}_{29} \mathrm{NO}_{2}$.

9c: ${ }^{1} \mathrm{H}$ NMR $\left(500 \mathrm{MHz}, \mathrm{CDCl}_{3}\right): \delta_{\mathrm{H}}=2.96(\mathrm{~m}, 2 \mathrm{H})$ és $3.08(\mathrm{~m}, 2 \mathrm{H}): 5-\mathrm{CH}_{2}$ és $6-\mathrm{CH}_{2}, 3.87$ (s, 3H, 3-OMe), 3.91 (s, 3H, 9-OMe), 6.78 (d, 1H, $J=2.4 \mathrm{~Hz}, 4-\mathrm{H}), 6.96$ (dd, 1H, $J=8.6$ $\mathrm{Hz}, J=2.4 \mathrm{~Hz}, 2-\mathrm{H}), 7.00$ (d, $1 \mathrm{H}, J=2.7 \mathrm{~Hz}, 8-\mathrm{H}), 7.29$ (dd, $1 \mathrm{H}, J=9.1 \mathrm{~Hz}, J=2.7 \mathrm{~Hz}, 10-$ $\mathrm{H}), 7.77(\mathrm{~s}, 1 \mathrm{H}, 7-\mathrm{H}), 8.01(\mathrm{~d}, 1 \mathrm{H}, J=9.1 \mathrm{~Hz}, 11-\mathrm{H}), 8.47(\mathrm{~d}, 1 \mathrm{H}, J=8.6 \mathrm{~Hz}, 1-\mathrm{H}) ;{ }^{13} \mathrm{C} \mathrm{NMR}$ $\left(125 \mathrm{MHz}, \mathrm{CDCl}_{3}\right): \delta_{\mathrm{C}}=28.7$ és $28.9(\mathrm{C}-5$ és C-6), 55.3 (3-OMe), $55.5(9-\mathrm{OMe}), 104.8(\mathrm{C}-$ 8), 112.9 (2C, C-2 és C-4), 121.0 (C-10), 127.3 (C-1), 128.3 (C-7a), 130.3 (C-6a), 130.4 (C11), 132.5 (C-7), 134.5 (C-12), 140.8 (C-4a), 148.8 (C-11a), 151.1 (C-12a), 157.3 (C-9), 160.6 (C-3); ESI-MS: $400[\mathrm{M}+\mathrm{H}]^{+} ; \mathrm{C}_{19} \mathrm{H}_{17} \mathrm{NO}_{2}$.

9d: ${ }^{1} \mathrm{H}$ NMR (500 MHz, $\left.\mathrm{CDCl}_{3}\right): \delta_{\mathrm{H}}={ }^{1} \mathrm{H}$ NMR $\left(\mathrm{CDCl}_{3}, 500 \mathrm{MHz}\right): \delta 2.98(\mathrm{~m}, 2 \mathrm{H})$ és 3.11 (m, 2H): 5- $\mathrm{CH}_{2}$ és 6- $\mathrm{CH}_{2}, 3.88(\mathrm{~s}, 3 \mathrm{H}, 3-\mathrm{OMe}), 6.78(\mathrm{~d}, 1 \mathrm{H}, J=2.4 \mathrm{~Hz}, 4-\mathrm{H}), 6.97(\mathrm{dd}, 1 \mathrm{H}$, $J=8.6 \mathrm{~Hz}, J=2.4 \mathrm{~Hz}, 2-\mathrm{H}), 7.33(\mathrm{t}, 1 \mathrm{H}, J=7.6 \mathrm{~Hz}, 9-\mathrm{H}), 7.62(\mathrm{~d}, 1 \mathrm{H}, J=7.6 \mathrm{~Hz}, 8-\mathrm{H})$, $7.74(\mathrm{~d}, 1 \mathrm{H}, J=7.6 \mathrm{~Hz}, 10-\mathrm{H}), 7.86(\mathrm{~s}, 1 \mathrm{H}, 7-\mathrm{H}), 8.63(\mathrm{~d}, 1 \mathrm{H}, J=8.6 \mathrm{~Hz}, 1-\mathrm{H}) ;{ }^{13} \mathrm{C} \mathrm{NMR}$ $\left(125 \mathrm{MHz}, \mathrm{CDCl}_{3}\right): \delta_{\mathrm{C}}=28.5$ és $28.6(\mathrm{C}-5$ és C-6), 55.3 (3-OMe), 112.8 és 113.2: C-2 és C4, 125.4 és 125.9: C-8 és C-9, 127.5 (C-7a), 128.4 és 128.7: C-1 és C-10, 128.7 (C-12), 130.8 (C-6a), 133.3 (C-11), 133.8 (C-7), 141.2 (C-4a), 143.6 (C-11a), 153.9 (C-12a), 161.2 (C-3); ESI-MS: $296[\mathrm{M}+\mathrm{H}]^{+} ; \mathrm{C}_{18} \mathrm{H}_{14} \mathrm{ClNO}$.

9e: ${ }^{1} \mathrm{H}$ NMR $\left(500 \mathrm{MHz}, \mathrm{CDCl}_{3}\right): \delta_{\mathrm{H}}=2.96(\mathrm{~m}, 2 \mathrm{H})$ és $3.08(\mathrm{~m}, 2 \mathrm{H}): 5-\mathrm{CH}_{2}$ és 6-CH $2,3.87$ (s, 3H, 3-OMe), 6.79 (d, 1H, $J=2.4 \mathrm{~Hz}, 4-\mathrm{H}), 6.96$ (dd, 1H, $J=8.6 \mathrm{~Hz}, J=2.4 \mathrm{~Hz}, 2-\mathrm{H})$, $7.55(\mathrm{dd}, 1 \mathrm{H}, J=8.9 \mathrm{~Hz}, J=2.2 \mathrm{~Hz}, 10-\mathrm{H}), 7.67$ (d, $1 \mathrm{H}, J=2.2 \mathrm{~Hz}, 8-\mathrm{H}), 7.76(\mathrm{~s}, 1 \mathrm{H}, 7-\mathrm{H})$, $8.02(\mathrm{~d}, 1 \mathrm{H}, J=8.9 \mathrm{~Hz}, 11-\mathrm{H}), 8.48(\mathrm{~d}, 1 \mathrm{H}, J=8.6 \mathrm{~Hz}, 1-\mathrm{H}) ;{ }^{13} \mathrm{C} \mathrm{NMR}\left(125 \mathrm{MHz}, \mathrm{CDCl}_{3}\right)$ : $\delta_{\mathrm{C}}=28.5$ és 28.8 (C-5 és C-6), 55.3 (3-OMe), 112.9 és 113.1 (C-2 és C-4), 125.5 (C-8), 127.3 (C-7a), 127.8 (C-1), 128.0 (C-6a), 129.4 (C-10), 130.6 (C-11), 131.0 és 131.1 (C-9 és C-12), 132.5 (C-7), 141.2 (C-4a), 148.4 (C-11a), 153.6 (C-12a), 161.1 (C-3); ESI-MS: 296 $[\mathrm{M}+\mathrm{H}]^{+} ; \mathrm{C}_{18} \mathrm{H}_{14} \mathrm{ClNO}$.

9f: ${ }^{1} \mathrm{H}$ NMR $\left(500 \mathrm{MHz}, \mathrm{CDCl}_{3}\right): \delta_{\mathrm{H}}=2.96(\mathrm{~m}, 2 \mathrm{H})$ és $3.09(\mathrm{~m}, 2 \mathrm{H}): 5-\mathrm{CH}_{2}$ és 6-CH, 3.87 (s, 3H, 3-OMe), 6.78 (d, 1H, $J=2.3 \mathrm{~Hz}, 4-\mathrm{H}), 6.96(\mathrm{dd}, 1 \mathrm{H}, J=8.6 \mathrm{~Hz}, J=2.3 \mathrm{~Hz}, 2-\mathrm{H})$, $7.68(\mathrm{dd}, 1 \mathrm{H}, J=8.9 \mathrm{~Hz}, J=1.9 \mathrm{~Hz}, 10-\mathrm{H}), 7.75(\mathrm{~s}, 1 \mathrm{H}, 7-\mathrm{H}), 7.85(\mathrm{~d}, 1 \mathrm{H}, J=1.9 \mathrm{~Hz}, 8-\mathrm{H})$, $7.96(\mathrm{~d}, 1 \mathrm{H}, J=8.9 \mathrm{~Hz}, 11-\mathrm{H}), 8.48(\mathrm{~d}, 1 \mathrm{H}, J=8.6 \mathrm{~Hz}, 1-\mathrm{H}) ;{ }^{13} \mathrm{C} \mathrm{NMR}\left(125 \mathrm{MHz}, \mathrm{CDCl}_{3}\right)$ : $\delta_{\mathrm{C}}=28.2$ és 28.4 (C-5 és C-6), 55.0 (3-OMe), 112.6 és 112.8 (C-2 és C-4), 118.9 (C-9), 127.5 (C-1), 128.2 (C-7a), 128.5 (C-8), 130.3 (C-11), 130.6 (C-6a), 131.6 (C-10), 132.1 (C7), 134.5 (C-12), 140.9 (C-4a), 147.1 (C-11a), 153.4 (C-12a), 160.8 (C-3); ESI-MS: 340 $[\mathrm{M}+\mathrm{H}]^{+} ; \mathrm{C}_{18} \mathrm{H}_{14} \mathrm{BrNO}$.

13a: ${ }^{1} \mathrm{H}$ NMR $\left(500 \mathrm{MHz}, \mathrm{CDCl}_{3}\right): \delta_{\mathrm{H}}=0.80\left(\mathrm{~s}, 3 \mathrm{H}, 18-\mathrm{CH}_{3}\right), 0.82\left(\mathrm{~s}, 3 \mathrm{H}, 19-\mathrm{CH}_{3}\right), 0.88(\mathrm{~m}$, $1 \mathrm{H}), 0.98(\mathrm{~m}, 1 \mathrm{H}), 1.07(\mathrm{~m}, 1 \mathrm{H}), 1.23(\mathrm{~m}, 1 \mathrm{H}), 1.29-1.55$ (átfedő m, 5H), 1.66-1.82 (átfedő m, 6H), 2.05 (s, 3H, Ac-CH $), 2.17(\mathrm{~m}, 1 \mathrm{H}), 2.60(\mathrm{~d}, 1 \mathrm{H}, J=16.0 \mathrm{~Hz}$, az egyik 1-H 2$), 2.79$

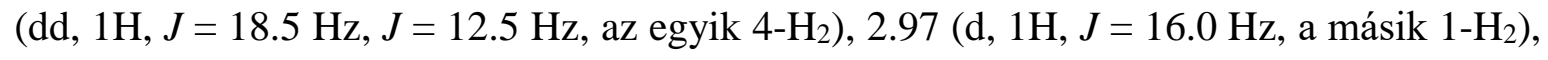
$3.08\left(\mathrm{dd}, 1 \mathrm{H}, J=18.5 \mathrm{~Hz}, J=5.5 \mathrm{~Hz}\right.$, a másik 4-H $\mathrm{H}_{2}, 4.62(\mathrm{t}, 1 \mathrm{H}, J=8.4 \mathrm{~Hz}, 17-\mathrm{H}), 7.42$ (tszerü m, 1H, 6'-H), 7.60 (t-szerü m, 1H, 7'-H), 7.69 (d, 1H, J=8.0 Hz, 5'-H), 7.79 (s, 1H, 
$\left.4^{\prime}-\mathrm{H}\right), 7.97\left(\mathrm{~d}, 1 \mathrm{H}, J=8.4 \mathrm{~Hz}, 8^{\prime}-\mathrm{H}\right) ;{ }^{13} \mathrm{C} \mathrm{NMR}\left(125 \mathrm{MHz}, \mathrm{CDCl}_{3}\right): \delta \mathrm{C}=11.6(\mathrm{C}-19), 12.0$ (C-18), $20.8\left(\mathrm{CH}_{2}\right), 21.2\left(\mathrm{Ac}-\mathrm{CH}_{3}\right), 23.5\left(\mathrm{CH}_{2}\right), 27.5\left(\mathrm{CH}_{2}\right), 28.6\left(\mathrm{CH}_{2}\right), 31.1\left(\mathrm{CH}_{2}\right), 35.3$ $(\mathrm{C}-10), 35.3(\mathrm{CH}), 36.9\left(\mathrm{CH}_{2}\right), 37.3\left(\mathrm{CH}_{2}\right), 42.2(\mathrm{CH}), 42.5(\mathrm{C}-13), 43.5\left(\mathrm{CH}_{2}\right), 50.7(\mathrm{CH})$, $53.5(\mathrm{CH}), 82.8(\mathrm{C}-17), 125.5\left(\mathrm{C}-6^{\prime}\right), 126.8\left(\mathrm{C}-5^{\prime}\right), 127.2\left(\mathrm{C}-4 \mathrm{a}^{\prime}\right), 128.2$ és 128.5 (C-7' és C8'), 130.0 (C-3'), 135.8 (C-4'), 146.6 (C-8a'), 158.3 (C-2'), 171.2 (Ac-CO); ESI-MS: 418 $[\mathrm{M}+\mathrm{H}]^{+}$; Anal. Calcd for $\mathrm{C}_{28} \mathrm{H}_{35} \mathrm{NO}_{2} \mathrm{C}, 80.53 ; \mathrm{H}, 8.45$. Found: C, 80.34; H, 8.30.

13b: ${ }^{1} \mathrm{H}$ NMR $\left(500 \mathrm{MHz}, \mathrm{CDCl}_{3}\right): \delta_{\mathrm{H}}=0.79\left(\mathrm{~s}, 3 \mathrm{H}, 18-\mathrm{CH}_{3}\right), 0.82\left(\mathrm{~s}, 3 \mathrm{H}, 19-\mathrm{CH}_{3}\right), 0.86(\mathrm{~m}$, $1 \mathrm{H}), 0.97(\mathrm{~m}, 1 \mathrm{H}), 1.05(\mathrm{~m}, 1 \mathrm{H}), 1.22(\mathrm{~m}, 1 \mathrm{H}), 1.28-1.54$ (átfedő $\mathrm{m}, 5 \mathrm{H}), 1.64-1.82$ (átfedő m, 6H), 2.05 (s, 3H, Ac- $\left.\mathrm{CH}_{3}\right), 2.17(\mathrm{~m}, 1 \mathrm{H}), 2.49\left(\mathrm{~s}, 3 \mathrm{H}, 6^{\prime}-\mathrm{CH}_{3}\right), 2.58$ (d, 1H, J = $16.0 \mathrm{~Hz}$, az egyik 1- $\left.\mathrm{H}_{2}\right), 2.77\left(\mathrm{dd}, 1 \mathrm{H}, J=18.3 \mathrm{~Hz}, J=12.8 \mathrm{~Hz}\right.$, az egyik $\left.4-\mathrm{H}_{2}\right), 2.95(\mathrm{~d}, 1 \mathrm{H}, J=16.0$ Hz, a másik 1-H $\left.\mathrm{H}_{2}\right) 3.06\left(\mathrm{dd}, 1 \mathrm{H}, J=18.3 \mathrm{~Hz}, J=4.7 \mathrm{~Hz}\right.$, a másik 4- $\mathrm{H}_{2}$ ), 4.62 (t-szerü m, 1H, 17-H), 7.44 (d, 1H, J=8.2 Hz, 7'-H), 7.44 (s, 1H, 5'-H), 7.71 (s, 1H, 4'-H), 7.88 (d, 1H, $\left.J=8.2 \mathrm{~Hz}, 8^{\prime}-\mathrm{H}\right) ;{ }^{13} \mathrm{C} \mathrm{NMR}\left(125 \mathrm{MHz}, \mathrm{CDCl}_{3}\right): \delta_{\mathrm{C}}=11.6(\mathrm{C}-19), 12.0(\mathrm{C}-18), 20.8\left(\mathrm{CH}_{2}\right)$,

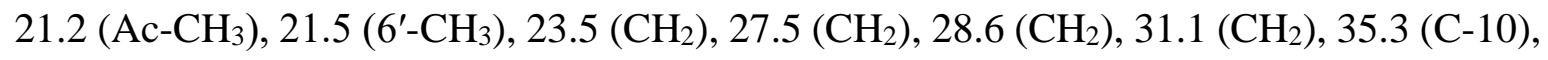
$35.3(\mathrm{CH}), 36.9\left(\mathrm{CH}_{2}\right), 37.1\left(\mathrm{CH}_{2}\right), 42.2(\mathrm{CH}), 42.5(\mathrm{C}-13), 43.5\left(\mathrm{CH}_{2}\right), 50.7(\mathrm{CH}), 53.5$ $(\mathrm{CH}), 82.8(\mathrm{C}-17), 125.6\left(\mathrm{C}-5^{\prime}\right), 127.2\left(\mathrm{C}-4 \mathrm{a}^{\prime}\right), 127.7\left(\mathrm{C}-8^{\prime}\right), 130.0\left(\mathrm{C}-3^{\prime}\right), 131.0\left(\mathrm{C}^{\prime} 7^{\prime}\right), 135.3$ (C-6'), 135.4 (C-4'), 146.4 (C-8a'), 157.2 (C-2'), 171.2 (Ac-CO); ESI-MS: 432 [M+H] ${ }^{+}$; $\mathrm{C}_{29} \mathrm{H}_{37} \mathrm{NO}_{2}$.

13c: ${ }^{1} \mathrm{H}$ NMR $\left(500 \mathrm{MHz}, \mathrm{CDCl}_{3}\right): \delta_{\mathrm{H}}=0.79\left(\mathrm{~s}, 3 \mathrm{H}, 18-\mathrm{CH}_{3}\right), 0.81\left(\mathrm{~s}, 3 \mathrm{H}, 19-\mathrm{CH}_{3}\right), 0.86(\mathrm{~m}$, $1 \mathrm{H}), 0.96(\mathrm{~m}, 1 \mathrm{H}), 1.06(\mathrm{~m}, 1 \mathrm{H}), 1.21(\mathrm{~m}, 1 \mathrm{H}), 1.28-1.54$ (átfedő m, 5H), 1.64-1.82 (átfedő m, 6H), $2.05\left(\mathrm{~s}, 3 \mathrm{H}, \mathrm{Ac}-\mathrm{CH}_{3}\right), 2.17(\mathrm{~m}, 1 \mathrm{H}), 2.57(\mathrm{~d}, 1 \mathrm{H}, J=16.0 \mathrm{~Hz}$, az egyik 1-H 2$), 2.74$ (dd, $1 \mathrm{H}, J=18.2 \mathrm{~Hz}, J=12.7 \mathrm{~Hz}$, az egyik 4-H $), 2.93(\mathrm{~d}, 1 \mathrm{H}, J=16.0 \mathrm{~Hz}$, a másik 1-H2), $3.05(\mathrm{dd}, 1 \mathrm{H}, J=18.2 \mathrm{~Hz}, J=5.4 \mathrm{~Hz}$, a másik 4-H2), 3.89 (s, 3H, 6'-OMe), $4.62(\mathrm{t}, 1 \mathrm{H}, J=$ $8.7 \mathrm{~Hz}, 17-\mathrm{H}), 6.95\left(\mathrm{~d}, 1 \mathrm{H}, J=2.6 \mathrm{~Hz}, 5^{\prime}-\mathrm{H}\right), 7.26\left(\mathrm{dd}, 1 \mathrm{H}, J=9.1 \mathrm{~Hz}, J=2.6 \mathrm{~Hz}, 7^{\prime}-\mathrm{H}\right)$, $7.68\left(\mathrm{~s}, 1 \mathrm{H}, 4^{\prime}-\mathrm{H}\right), 7.86\left(\mathrm{~d}, 1 \mathrm{H}, J=9.1 \mathrm{~Hz}, 8^{\prime}-\mathrm{H}\right) ;{ }^{13} \mathrm{C} \mathrm{NMR}\left(125 \mathrm{MHz}, \mathrm{CDCl}_{3}\right): \delta_{\mathrm{C}}=11.6$ (C-19), $12.0(\mathrm{C}-18), 20.8\left(\mathrm{CH}_{2}\right), 21.2\left(\mathrm{Ac}-\mathrm{CH}_{3}\right), 23.5\left(\mathrm{CH}_{2}\right), 27.5\left(\mathrm{CH}_{2}\right), 28.6\left(\mathrm{CH}_{2}\right), 31.1$ $\left(\mathrm{CH}_{2}\right), 35.3(\mathrm{C}-10), 35.3(\mathrm{CH}), 36.9\left(\mathrm{CH}_{2}\right), 37.0\left(\mathrm{CH}_{2}\right), 42.2(\mathrm{CH}), 42.5(\mathrm{C}-13), 43.5\left(\mathrm{CH}_{2}\right)$, $50.7(\mathrm{CH}), 53.5(\mathrm{CH}), 55.4\left(6^{\prime}-\mathrm{OMe}\right), 82.8(\mathrm{C}-17), 104.3\left(\mathrm{C}-5^{\prime}\right), 121.3\left(\mathrm{C}-7^{\prime}\right), 128.0\left(\mathrm{C}-4 \mathrm{a}^{\prime}\right)$, $129.6\left(\mathrm{C}-8^{\prime}\right), 130.3\left(\mathrm{C}-3^{\prime}\right), 134.7\left(\mathrm{C}-4^{\prime}\right), 146.5\left(\mathrm{C}-8 \mathrm{a}^{\prime}\right), 155.5$ és 157.1 (C-2' és C-6'), 171.2 (Ac-CO); ESI-MS: $448[\mathrm{M}+\mathrm{H}]^{+} ; \mathrm{C}_{29} \mathrm{H}_{37} \mathrm{NO}_{3}$.

13d: ${ }^{1} \mathrm{H}$ NMR $\left(500 \mathrm{MHz}, \mathrm{CDCl}_{3}\right): \delta_{\mathrm{H}}=0.79\left(\mathrm{~s}, 3 \mathrm{H}, 18-\mathrm{CH}_{3}\right), 0.81\left(\mathrm{~s}, 3 \mathrm{H}, 19-\mathrm{CH}_{3}\right), 0.87(\mathrm{~m}$, $1 \mathrm{H}), 0.98(\mathrm{~m}, 1 \mathrm{H}), 1.06(\mathrm{~m}, 1 \mathrm{H}), 1.22(\mathrm{~m}, 1 \mathrm{H}), 1.28-1.55$ (átfedő $\mathrm{m}, 5 \mathrm{H}), 1.65-1.82$ (átfedő $\mathrm{m}, 6 \mathrm{H}), 2.05\left(\mathrm{~s}, 3 \mathrm{H}, \mathrm{Ac}-\mathrm{CH}_{3}\right), 2.17(\mathrm{~m}, 1 \mathrm{H}), 2.58(\mathrm{~d}, 1 \mathrm{H}, J=16.1 \mathrm{~Hz}$, az egyik 1-H 2$), 2.87$

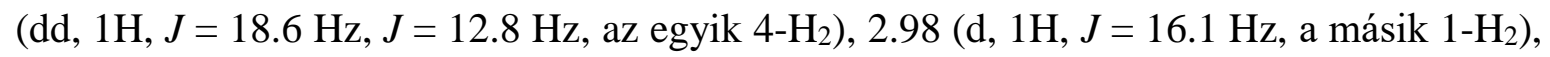
$3.21\left(\mathrm{dd}, 1 \mathrm{H}, J=18.6 \mathrm{~Hz}, J=5.3 \mathrm{~Hz}\right.$, a másik 4- $\left.\mathrm{H}_{2}\right), 4.62(\mathrm{t}, 1 \mathrm{H}, J=8.6 \mathrm{~Hz}, 17-\mathrm{H}), 7.33(\mathrm{t}-$ szerü m, 1H, 6'-H), 7.61 (d, 1H, $\left.J=8.1 \mathrm{~Hz}, 5^{\prime}-\mathrm{H}\right), 7.71\left(\mathrm{~d}, 1 \mathrm{H}, J=7.3 \mathrm{~Hz}, 7^{\prime}-\mathrm{H}\right), 7.80$ (s, $\left.1 \mathrm{H}, 4^{\prime}-\mathrm{H}\right) ;{ }^{13} \mathrm{C}$ NMR $\left(125 \mathrm{MHz}, \mathrm{CDCl}_{3}\right): \delta_{\mathrm{C}}=11.7(\mathrm{C}-19), 12.0(\mathrm{C}-18), 20.8\left(\mathrm{CH}_{2}\right), 21.2$ $\left(\mathrm{Ac}-\mathrm{CH}_{3}\right), 23.5\left(\mathrm{CH}_{2}\right), 27.5\left(\mathrm{CH}_{2}\right), 28.4\left(\mathrm{CH}_{2}\right), 31.1\left(\mathrm{CH}_{2}\right), 35.2(\mathrm{C}-10), 35.3(\mathrm{CH}), 36.9$ $\left(\mathrm{CH}_{2}\right), 37.5\left(\mathrm{CH}_{2}\right), 42.1(\mathrm{CH}), 42.5(\mathrm{C}-13), 43.3\left(\mathrm{CH}_{2}\right), 50.7(\mathrm{CH}), 53.4(\mathrm{CH}), 82.7(\mathrm{C}-17)$, 125.3 és 126.0 (C-5' és C-6'), 128.5 (C-4a'), 128.5 (C-7'), 131.1 (C-3'), 132.3 (C-8'), 136.1

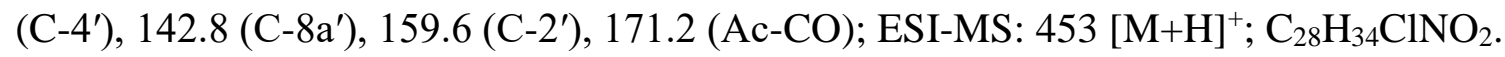


13e: ${ }^{1} \mathrm{H}$ NMR $\left(500 \mathrm{MHz}, \mathrm{CDCl}_{3}\right): \delta_{\mathrm{H}}=0.79\left(\mathrm{~s}, 3 \mathrm{H}, 18-\mathrm{CH}_{3}\right), 0.82\left(\mathrm{~s}, 3 \mathrm{H}, 19-\mathrm{CH}_{3}\right), 0.88(\mathrm{~m}$, $1 \mathrm{H}), 0.98(\mathrm{~m}, 1 \mathrm{H}), 1.08(\mathrm{~m}, 1 \mathrm{H}), 1.23(\mathrm{~m}, 1 \mathrm{H}), 1.29-1.55$ (átfedő m, 5H), 1.64-1.82 (átfedő $\mathrm{m}, 6 \mathrm{H}), 2.05\left(\mathrm{~s}, 3 \mathrm{H}, \mathrm{Ac}-\mathrm{CH}_{3}\right), 2.17(\mathrm{~m}, 1 \mathrm{H}), 2.59$ (d, 1H, $J=16.2 \mathrm{~Hz}$, az egyik 1-H $\left.\mathrm{H}_{2}\right), 2.76$ $\left(\mathrm{dd}, 1 \mathrm{H}, J=18.4 \mathrm{~Hz}, J=12.9 \mathrm{~Hz}\right.$, az egyik 4- $\left.\mathrm{H}_{2}\right), 2.97\left(\mathrm{~d}, 1 \mathrm{H}, J=16.2 \mathrm{~Hz}\right.$, a másik $\left.1-\mathrm{H}_{2}\right)$, $3.05(\mathrm{dd}, 1 \mathrm{H}, J=18.4 \mathrm{~Hz}, J=5.2 \mathrm{~Hz}$, a másik 4-H $), 4.62(\mathrm{t}, 1 \mathrm{H}, J=8.5 \mathrm{~Hz}, 17-\mathrm{H}), 7.53$ $\left(\mathrm{dd}, 1 \mathrm{H}, J=8.9 \mathrm{~Hz}, J=1.9 \mathrm{~Hz}, 7^{\prime}-\mathrm{H}\right), 7.66\left(\mathrm{~d}, 1 \mathrm{H}, J=1.9 \mathrm{~Hz}, 5^{\prime}-\mathrm{H}\right), 7.70$ (s, 1H, 4'-H), 7.90 $\left(\mathrm{d}, 1 \mathrm{H}, J=8.9 \mathrm{~Hz}, 8^{\prime}-\mathrm{H}\right) ;{ }^{13} \mathrm{C}$ NMR $\left(125 \mathrm{MHz}, \mathrm{CDCl}_{3}\right): \delta \mathrm{C}=11.8(\mathrm{C}-19), 12.0(\mathrm{C}-18), 20.8$ $\left(\mathrm{CH}_{2}\right), 21.2\left(\mathrm{Ac}-\mathrm{CH}_{3}\right), 23.5\left(\mathrm{CH}_{2}\right), 27.5\left(\mathrm{CH}_{2}\right), 28.5\left(\mathrm{CH}_{2}\right), 31.1\left(\mathrm{CH}_{2}\right), 35.3(\mathrm{C}-10), 35.3$ $(\mathrm{CH}), 36.9\left(\mathrm{CH}_{2}\right), 37.2\left(\mathrm{CH}_{2}\right), 42.1(\mathrm{CH}), 42.5(\mathrm{C}-13), 43.5\left(\mathrm{CH}_{2}\right), 50.7(\mathrm{CH}), 53.4(\mathrm{CH})$, 82.7 (C-17), 125.4 (C-5'), 127.8 (C-4a'), 129.4 és 129.8 (C-7' és C-8'), 131.1 (2C, C-6' és C3'), 134.8 (C-4'), $144.9\left(\mathrm{C}-8 \mathrm{a}^{\prime}\right), 158.7$ (C-2'), 171.2 (Ac-CO); ESI-MS: $453[\mathrm{M}+\mathrm{H}]^{+}$; $\mathrm{C}_{28} \mathrm{H}_{34} \mathrm{ClNO}_{2}$.

13f: ${ }^{1} \mathrm{H}$ NMR $\left(500 \mathrm{MHz}, \mathrm{CDCl}_{3}\right): \delta_{\mathrm{H}}=0.79\left(\mathrm{~s}, 3 \mathrm{H}, 18-\mathrm{CH}_{3}\right), 0.82\left(\mathrm{~s}, 3 \mathrm{H}, 19-\mathrm{CH}_{3}\right), 0.88(\mathrm{~m}$, $1 \mathrm{H}), 0.98(\mathrm{~m}, 1 \mathrm{H}), 1.08(\mathrm{~m}, 1 \mathrm{H}), 1.22(\mathrm{~m}, 1 \mathrm{H}), 1.28-1.55$ (átfedő $\mathrm{m}, 5 \mathrm{H}), 1.64-1.82$ (átfedő $\mathrm{m}, 6 \mathrm{H}), 2.05\left(\mathrm{~s}, 3 \mathrm{H}, \mathrm{Ac}-\mathrm{CH}_{3}\right), 2.17(\mathrm{~m}, 1 \mathrm{H}), 2.59\left(\mathrm{~d}, 1 \mathrm{H}, J=16.2 \mathrm{~Hz}\right.$, az egyik 1- $\left.\mathrm{H}_{2}\right), 2.75$

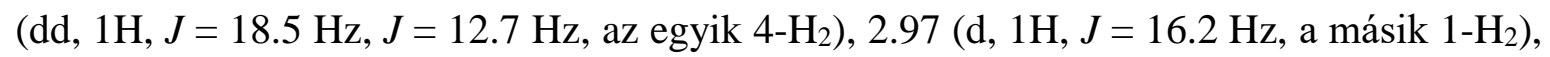
$3.04(\mathrm{dd}, 1 \mathrm{H}, J=18.5 \mathrm{~Hz}, J=5.4 \mathrm{~Hz}$, a másik 4-H $)$, 4.62 (t-szerü m, 1H, 17-H), 7.65 (dd, $\left.1 \mathrm{H}, J=9.0 \mathrm{~Hz}, J=2.0 \mathrm{~Hz}, 7^{\prime}-\mathrm{H}\right), 7.69$ (s, 1H, 5'-H), 7.82 (d, 1H, J=9.0 Hz, 8'-H), 7.83 (s, $\left.1 \mathrm{H}, 4^{\prime}-\mathrm{H}\right) ;{ }^{13} \mathrm{C}$ NMR $\left(125 \mathrm{MHz}, \mathrm{CDCl}_{3}\right): \delta_{\mathrm{C}}=11.7(\mathrm{C}-19), 12.1(\mathrm{C}-18), 20.8\left(\mathrm{CH}_{2}\right), 21.2$ $\left(\mathrm{Ac}-\mathrm{CH}_{3}\right), 23.5\left(\mathrm{CH}_{2}\right), 27.5\left(\mathrm{CH}_{2}\right), 28.5\left(\mathrm{CH}_{2}\right), 31.1\left(\mathrm{CH}_{2}\right), 35.3(\mathrm{C}-10), 35.3(\mathrm{CH}), 36.9$ $\left(\mathrm{CH}_{2}\right), 37.3\left(\mathrm{CH}_{2}\right), 42.1(\mathrm{CH}), 42.5(\mathrm{C}-13), 43.5\left(\mathrm{CH}_{2}\right), 50.7(\mathrm{CH}), 53.4(\mathrm{CH}), 82.7(\mathrm{C}-17)$, $119.2\left(\mathrm{C}-6^{\prime}\right), 128.3\left(\mathrm{C}-4 \mathrm{a}^{\prime}\right), 128.8$ (C-5'), $130.0\left(\mathrm{C}-8^{\prime}\right), 131.1\left(\mathrm{C}-3^{\prime}\right), 131.9\left(\mathrm{C}-7^{\prime}\right), 134.7$ (C4'), 145.2 (C-8a'), 158.9 (C-2'), 171.2 (Ac-CO); ESI-MS: $498[\mathrm{M}+\mathrm{H}]^{+} ; \mathrm{C}_{28} \mathrm{H}_{34} \mathrm{BrNO}_{2}$.

13g: ${ }^{1} \mathrm{H}$ NMR $\left(500 \mathrm{MHz}, \mathrm{CDCl}_{3}\right): \delta_{\mathrm{H}}=0.78\left(\mathrm{~s}, 3 \mathrm{H}, 18-\mathrm{CH}_{3}\right), 0.81\left(\mathrm{~s}, 3 \mathrm{H}, 19-\mathrm{CH}_{3}\right), 0.86(\mathrm{~m}$, $1 \mathrm{H}), 0.96(\mathrm{~m}, 1 \mathrm{H}), 1.06(\mathrm{~m}, 1 \mathrm{H}), 1.22(\mathrm{~m}, 1 \mathrm{H}), 1.29-1.55$ (átfedő $\mathrm{m}, 5 \mathrm{H}), 1.64-1.82$ (átfedő $\mathrm{m}, 6 \mathrm{H}), 2.05\left(\mathrm{~s}, 3 \mathrm{H}, \mathrm{Ac}-\mathrm{CH}_{3}\right), 2.17(\mathrm{~m}, 1 \mathrm{H}), 2.56(\mathrm{~d}, 1 \mathrm{H}, J=16.1 \mathrm{~Hz}$, az egyik 1-H 2$), 2.76$ $\left(\mathrm{dd}, 1 \mathrm{H}, J=18.5 \mathrm{~Hz}, J=12.7 \mathrm{~Hz}\right.$, az egyik 4- $\left.\mathrm{H}_{2}\right), 2.94\left(\mathrm{~d}, 1 \mathrm{H}, J=16.1 \mathrm{~Hz}\right.$, a másik $\left.1-\mathrm{H}_{2}\right)$, $3.05(\mathrm{dd}, 1 \mathrm{H}, J=18.5 \mathrm{~Hz}, J=5.4 \mathrm{~Hz} \text {, a másik 4-H })_{2}, 4.62(\mathrm{t}, 1 \mathrm{H}, J=8.6 \mathrm{~Hz}, 17-\mathrm{H}), 7.37$ (dd, 1H, $\left.J=8.7 \mathrm{~Hz}, J=1.8 \mathrm{~Hz}, 6^{\prime}-\mathrm{H}\right), 7.61\left(\mathrm{~d}, 1 \mathrm{H}, J=8.7 \mathrm{~Hz}, 5^{\prime}-\mathrm{H}\right), 7.76$ (s, 1H, 4'-H), 7.96 $\left(\mathrm{dd}, 1 \mathrm{H}, J=1.8 \mathrm{~Hz}, 8^{\prime}-\mathrm{H}\right) ;{ }^{13} \mathrm{C} \mathrm{NMR}\left(125 \mathrm{MHz}, \mathrm{CDCl}_{3}\right): \delta_{\mathrm{C}}=11.7(\mathrm{C}-19), 12.0(\mathrm{C}-18), 20.8$ $\left(\mathrm{CH}_{2}\right), 21.2\left(\mathrm{Ac}-\mathrm{CH}_{3}\right), 23.5\left(\mathrm{CH}_{2}\right), 27.5\left(\mathrm{CH}_{2}\right), 28.5\left(\mathrm{CH}_{2}\right), 31.1\left(\mathrm{CH}_{2}\right), 35.3(\mathrm{C}-10), 35.3$ $(\mathrm{CH}), 36.9\left(\mathrm{CH}_{2}\right), 37.3\left(\mathrm{CH}_{2}\right), 42.1(\mathrm{CH}), 42.5(\mathrm{C}-13), 43.4\left(\mathrm{CH}_{2}\right), 50.7(\mathrm{CH}), 53.4(\mathrm{CH})$, 82.7 (C-17), $125.5\left(\mathrm{C}-4 \mathrm{a}^{\prime}\right), 126.5\left(\mathrm{C}-6^{\prime}\right), 127.3\left(\mathrm{C}-8^{\prime}\right), 128.0\left(\mathrm{C}-5^{\prime}\right), 130.4\left(\mathrm{C}-3^{\prime}\right), 134.2(\mathrm{C}-$ 7'), $135.6\left(\mathrm{C}-4^{\prime}\right), 146.9\left(\mathrm{C}-8 \mathrm{a}^{\prime}\right), 159.5\left(\mathrm{C}-2^{\prime}\right), 171.2(\mathrm{Ac}-\mathrm{CO})$; ESI-MS: $453[\mathrm{M}+\mathrm{H}]^{+}$; $\mathrm{C}_{28} \mathrm{H}_{34} \mathrm{ClNO}_{2}$.

13g': ${ }^{1} \mathrm{H}$ NMR $\left(500 \mathrm{MHz}, \mathrm{CDCl}_{3}\right): \delta_{\mathrm{H}}=0.80\left(\mathrm{~s}, 3 \mathrm{H}, 18-\mathrm{CH}_{3}\right), 0.82\left(\mathrm{~s}, 3 \mathrm{H}, 19-\mathrm{CH}_{3}\right), 0.89$ $(\mathrm{m}, 1 \mathrm{H}), 0.97(\mathrm{~m}, 1 \mathrm{H}), 1.08(\mathrm{~m}, 1 \mathrm{H}), 1.23(\mathrm{~m}, 1 \mathrm{H}), 1.28-1.55$ (átfedő $\mathrm{m}, 5 \mathrm{H}), 1.66-1.83$ (átfedő m, 6H), $2.05\left(\mathrm{~s}, 3 \mathrm{H}, \mathrm{Ac}_{-} \mathrm{CH}_{3}\right), 2.18(\mathrm{~m}, 1 \mathrm{H}), 2.63(\mathrm{~d}, 1 \mathrm{H}, J=16.2 \mathrm{~Hz}$, az egyik 1$\left.\mathrm{H}_{2}\right), 2.78$ (dd, $1 \mathrm{H}, J=18.5 \mathrm{~Hz}, J=12.7 \mathrm{~Hz}$, az egyik 4-H $), 3.06(\mathrm{~d}, 1 \mathrm{H}, J=16.2 \mathrm{~Hz}$, a másik $\left.1-\mathrm{H}_{2}\right), 3.10\left(\mathrm{dd}, 1 \mathrm{H}, J=18.5 \mathrm{~Hz}, J=5.4 \mathrm{~Hz}\right.$, a másik 4- $\left.\mathrm{H}_{2}\right), 4.63(\mathrm{t}, 1 \mathrm{H}, J=8.6 \mathrm{~Hz}, 17-\mathrm{H})$, $7.50\left(\mathrm{~m}, 2 \mathrm{H}, 6^{\prime}-\mathrm{H}\right.$ és $\left.7^{\prime}-\mathrm{H}\right), 7.90\left(\mathrm{dd}, 1 \mathrm{H}, J=5.9 \mathrm{~Hz}, J=3.1 \mathrm{~Hz}, 8^{\prime}-\mathrm{H}\right), 8.20$ (s, 1H, 4'-H); 
${ }^{13} \mathrm{C}$ NMR $\left(125 \mathrm{MHz}, \mathrm{CDCl}_{3}\right): \delta \mathrm{C}=11.7(\mathrm{C}-19), 12.1(\mathrm{C}-18), 20.8\left(\mathrm{CH}_{2}\right), 21.2\left(\mathrm{Ac}^{\left.-\mathrm{CH}_{3}\right),}\right.$ $23.5\left(\mathrm{CH}_{2}\right), 27.5\left(\mathrm{CH}_{2}\right), 28.5\left(\mathrm{CH}_{2}\right), 31.1\left(\mathrm{CH}_{2}\right), 35.3(\mathrm{CH}), 35.3(\mathrm{C}-10), 36.9\left(\mathrm{CH}_{2}\right), 37.1$ $\left(\mathrm{CH}_{2}\right), 42.1(\mathrm{CH}), 42.5(\mathrm{C}-13), 43.6\left(\mathrm{CH}_{2}\right), 50.7(\mathrm{CH}), 53.4(\mathrm{CH}), 82.7(\mathrm{C}-17), 125.3(\mathrm{C}-$ $\left.4 \mathrm{a}^{\prime}\right), 125.5,127.5$ és 128.2 (C-6', C-7' és C-8'), 130.4 (C-5'), 131.3 (C-3'), $132.6\left(\mathrm{C}-4^{\prime}\right), 147.2$ (C-8a'), 159.2 (C-2'), 171.2 (Ac-CO); ESI-MS: $453[\mathrm{M}+\mathrm{H}]^{+} ; \mathrm{C}_{28} \mathrm{H}_{34} \mathrm{ClNO}_{2}$.

13h: ${ }^{1} \mathrm{H}$ NMR $\left(500 \mathrm{MHz}, \mathrm{CDCl}_{3}\right): \delta_{\mathrm{H}}=0.81\left(\mathrm{~s}, 3 \mathrm{H}, 18-\mathrm{CH}_{3}\right), 0.82\left(\mathrm{~s}, 3 \mathrm{H}, 19-\mathrm{CH}_{3}\right), 0.87(\mathrm{~m}$, $1 \mathrm{H}), 0.98(\mathrm{~m}, 1 \mathrm{H}), 1.06(\mathrm{~m}, 1 \mathrm{H}), 1.22(\mathrm{~m}, 1 \mathrm{H}), 1.29-1.55$ (átfedő $\mathrm{m}, 5 \mathrm{H}), 1.66-1.82$ (átfedő $\mathrm{m}, 6 \mathrm{H}), 2.06\left(\mathrm{~s}, 3 \mathrm{H}, \mathrm{Ac}-\mathrm{CH}_{3}\right), 2.18(\mathrm{~m}, 1 \mathrm{H}), 2.58(\mathrm{~d}, 1 \mathrm{H}, J=16.0 \mathrm{~Hz}$, az egyik 1-H 2$), 2.78$ $\left(\mathrm{s}, 3 \mathrm{H}, 8^{\prime}-\mathrm{CH}_{3}\right), 2.82(\mathrm{dd}, 1 \mathrm{H}, J=18.2 \mathrm{~Hz}, J=12.7 \mathrm{~Hz}$, az egyik 4-H 2 ), 2.97 (d, 1H, $J=16.0$

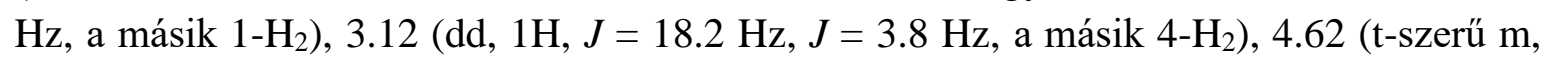
1H, 17-H), 7.31 (t-szerü m, 1H, 6'-H), 7.45 (d, 1H, $\left.J=6.8 \mathrm{~Hz}, 7^{\prime}-\mathrm{H}\right), 7.54$ (d, 1H, $J=8.1$ $\left.\mathrm{Hz}, 5^{\prime}-\mathrm{H}\right), 7.75$ (s, 1H, 4'-H); ${ }^{13} \mathrm{C}$ NMR (125 MHz, $\left.\mathrm{CDCl}_{3}\right): \delta_{\mathrm{C}}=11.7$ (C-19), $12.0(\mathrm{C}-18)$,

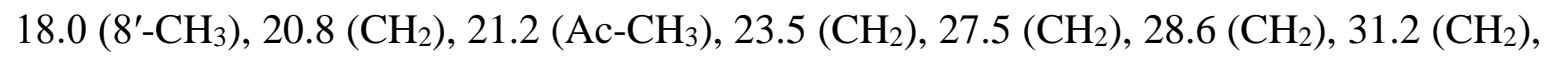
$35.2(\mathrm{C}-10), 35.4(\mathrm{CH}), 36.9\left(\mathrm{CH}_{2}\right), 37.6\left(\mathrm{CH}_{2}\right), 42.3(\mathrm{CH}), 42.5(\mathrm{C}-13), 43.5\left(\mathrm{CH}_{2}\right), 50.7$ $(\mathrm{CH}), 53.5(\mathrm{CH}), 82.8(\mathrm{C}-17), 124.9$ és $125.2\left(\mathrm{C}-5^{\prime}\right.$ és C-6'), $127.1\left(\mathrm{C}-4 \mathrm{a}^{\prime}\right), 128.5\left(\mathrm{C}-7^{\prime}\right)$, $129.6\left(\mathrm{C}-3^{\prime}\right), 132.1\left(\mathrm{C}-8^{\prime}\right), 135.9\left(\mathrm{C}-4^{\prime}\right), 136.0\left(\mathrm{C}-8 \mathrm{a}^{\prime}\right), 157.2\left(\mathrm{C}-2^{\prime}\right), 171.2$ (Ac-CO); ESIMS: $432[\mathrm{M}+\mathrm{H}]^{+} ; \mathrm{C}_{29} \mathrm{H}_{37} \mathrm{NO}_{2}$.

13i: ${ }^{1} \mathrm{H}$ NMR $\left(500 \mathrm{MHz}, \mathrm{CDCl}_{3}\right): \delta_{\mathrm{H}}=0.77\left(\mathrm{~s}, 3 \mathrm{H}, 18-\mathrm{CH}_{3}\right), 0.81\left(\mathrm{~s}, 3 \mathrm{H}, 19-\mathrm{CH}_{3}\right), 0.85(\mathrm{~m}$, $1 \mathrm{H}), 0.96(\mathrm{~m}, 1 \mathrm{H}), 1.04(\mathrm{~m}, 1 \mathrm{H}), 1.22(\mathrm{~m}, 1 \mathrm{H}), 1.29-1.55$ (átfedő $\mathrm{m}, 5 \mathrm{H}), 1.64-1.80$ (átfedő m, 6H), $2.04\left(\mathrm{~s}, 3 \mathrm{H}, \mathrm{Ac}^{-} \mathrm{CH}_{3}\right), 2.15(\mathrm{~m}, 1 \mathrm{H}), 2.51\left(\mathrm{~s}, 3 \mathrm{H}, 7^{\prime}-\mathrm{CH}_{3}\right), 2.55(\mathrm{~d}, 1 \mathrm{H}, J=16.0 \mathrm{~Hz}$, az egyik 1-H $\mathrm{H}_{2}, 2.75\left(\mathrm{dd}, 1 \mathrm{H}, J=18.3 \mathrm{~Hz}, J=12.3 \mathrm{~Hz}\right.$, az egyik $\left.4-\mathrm{H}_{2}\right), 2.93(\mathrm{~d}, 1 \mathrm{H}, J=16.0$ $\mathrm{Hz}$, a másik 1-H2), $3.05(\mathrm{dd}, 1 \mathrm{H}, J=18.5 \mathrm{~Hz}, J=5.8 \mathrm{~Hz}$, a másik 4-H2), 4.61 (t-szerü m, $1 \mathrm{H}, 17-\mathrm{H}), 7.25\left(\mathrm{~d}, 1 \mathrm{H}, J=8.0 \mathrm{~Hz}, 6^{\prime}-\mathrm{H}\right), 7.57$ (d, 1H, $\left.J=8.0 \mathrm{~Hz}, 5^{\prime}-\mathrm{H}\right), 7.73$ (s, 1H) és 7.75 (s, 1H): 4'-H és $8^{\prime}-\mathrm{H} ;{ }^{13} \mathrm{C}$ NMR $\left(125 \mathrm{MHz}, \mathrm{CDCl}_{3}\right): \delta_{\mathrm{C}}=11.6(\mathrm{C}-19), 12.0(\mathrm{C}-18), 20.8$ $\left(\mathrm{CH}_{2}\right), 21.2\left(\mathrm{Ac}-\mathrm{CH}_{3}\right), 21.8\left(7^{\prime}-\mathrm{CH}_{3}\right), 23.5\left(\mathrm{CH}_{2}\right), 27.5\left(\mathrm{CH}_{2}\right), 28.6\left(\mathrm{CH}_{2}\right), 31.1\left(\mathrm{CH}_{2}\right), 35.3$ (C-10), $35.3(\mathrm{CH}), 36.9\left(\mathrm{CH}_{2}\right), 37.3\left(\mathrm{CH}_{2}\right), 42.1(\mathrm{CH}), 42.5(\mathrm{C}-13), 43.4\left(\mathrm{CH}_{2}\right), 50.7(\mathrm{CH})$, $53.4(\mathrm{CH}), 82.8(\mathrm{C}-17), 125.3\left(\mathrm{C}-4 \mathrm{a}^{\prime}\right), 126.4\left(\mathrm{C}-6^{\prime}\right), 127.2\left(\mathrm{C}-8^{\prime}\right), 127.8\left(\mathrm{C}-5^{\prime}\right), 129.1\left(\mathrm{C}-3^{\prime}\right)$, $135.5\left(\mathrm{C}-4^{\prime}\right), 138.6\left(\mathrm{C}-7^{\prime}\right), 146.9\left(\mathrm{C}-8 \mathrm{a}^{\prime}\right), 158.1\left(\mathrm{C}-2^{\prime}\right), 171.2$ (Ac-CO); ESI-MS: 432 $[\mathrm{M}+\mathrm{H}]^{+} ; \mathrm{C}_{29} \mathrm{H}_{37} \mathrm{NO}_{2}$.

14a: ${ }^{1} \mathrm{H}$ NMR $\left(500 \mathrm{MHz}, \mathrm{CDCl}_{3}\right): \delta_{\mathrm{H}}=0.77\left(\mathrm{~s}, 3 \mathrm{H}, 18-\mathrm{CH}_{3}\right), 0.79\left(\mathrm{~s}, 3 \mathrm{H}, 19-\mathrm{CH}_{3}\right), 0.85(\mathrm{~m}$, $1 \mathrm{H}), 0.96(\mathrm{~m}, 1 \mathrm{H}), 1.12(\mathrm{~m}, 1 \mathrm{H}), 1.24-1.48$ (átfedő $\mathrm{m}, 5 \mathrm{H}$ ), 1.63-1.75 (átfedő m, 6H), 1.87 (m, 1H), $2.06(\mathrm{~m}, 1 \mathrm{H}), 2.58\left(\mathrm{~d}, 1 \mathrm{H}, J=16.0 \mathrm{~Hz}\right.$, az egyik 1- $\left.\mathrm{H}_{2}\right), 2.79$ (dd, $1 \mathrm{H}, J=18.1 \mathrm{~Hz}$, $J=14.1 \mathrm{~Hz}$, az egyik 4- $\left.\mathrm{H}_{2}\right), 2.98\left(\mathrm{~d}, 1 \mathrm{H}, J=16.0 \mathrm{~Hz}\right.$, a másik $\left.1-\mathrm{H}_{2}\right), 3.08(\mathrm{dd}, 1 \mathrm{H}, J=18.1$ $\mathrm{Hz}, J=4.1 \mathrm{~Hz}$, a másik 4-H2), 3.66 (t, 1H, $J=7.5 \mathrm{~Hz}, 17-\mathrm{H}$ ), 7.42 (t-szerü m, 1H, 6'-H), 7.60 (t-szerü m, 1H, 7'-H), 7.69 (d, 1H, J=7.8 Hz, 5'-H), 7.79 (s, 1H, 4'-H), 7.97 (d, 1H, J $\left.=8.1 \mathrm{~Hz}, 8^{\prime}-\mathrm{H}\right) ;{ }^{13} \mathrm{C}$ NMR $\left(125 \mathrm{MHz}, \mathrm{CDCl}_{3}\right): \delta_{\mathrm{C}}=11.1(\mathrm{C}-19), 11.7(\mathrm{C}-18), 20.9\left(\mathrm{CH}_{2}\right)$, $23.4\left(\mathrm{CH}_{2}\right), 28.6\left(\mathrm{CH}_{2}\right), 30.5\left(\mathrm{CH}_{2}\right), 31.2\left(\mathrm{CH}_{2}\right), 35.3(\mathrm{C}-10), 35.6(\mathrm{CH}), 36.7\left(\mathrm{CH}_{2}\right), 37.3$ $\left(\mathrm{CH}_{2}\right), 42.3(\mathrm{CH}), 42.9(\mathrm{C}-13), 43.5\left(\mathrm{CH}_{2}\right), 50.9(\mathrm{CH}), 53.7(\mathrm{CH}), 81.8(\mathrm{C}-17), 125.5\left(\mathrm{C}-66^{\prime}\right)$, $126.8\left(\mathrm{C}^{-5}\right), 127.2\left(\mathrm{C}-4 \mathrm{a}^{\prime}\right), 128.1$ és $128.6\left(\mathrm{C}-7^{\prime}\right.$ és C-8'), $130.1\left(\mathrm{C}-3^{\prime}\right), 135.8\left(\mathrm{C}-4^{\prime}\right), 146.5$ (C-8a'), $158.3\left(\mathrm{C}-2^{\prime}\right)$; ESI-MS: $476[\mathrm{M}+\mathrm{H}]^{+} ; \mathrm{C}_{26} \mathrm{H}_{33} \mathrm{NO}$. 
14b: ${ }^{1} \mathrm{H}$ NMR $\left(500 \mathrm{MHz}, \mathrm{CDCl}_{3}\right): \delta_{\mathrm{H}}=0.77\left(\mathrm{~s}, 3 \mathrm{H}, 18-\mathrm{CH}_{3}\right), 0.79\left(\mathrm{~s}, 3 \mathrm{H}, 19-\mathrm{CH}_{3}\right), 0.85(\mathrm{~m}$, $1 \mathrm{H}), 0.97(\mathrm{~m}, 1 \mathrm{H}), 1.12(\mathrm{~m}, 1 \mathrm{H}), 1.25-1.50$ (átfedő $\mathrm{m}, 5 \mathrm{H}), 1.60-1.73$ (átfedő m, 6H), 1.87

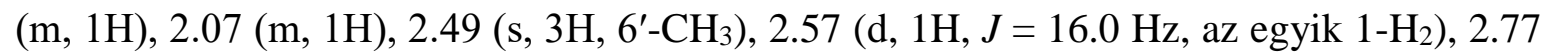
$\left(\mathrm{dd}, 1 \mathrm{H}, J=18.1 \mathrm{~Hz}, J=13.5 \mathrm{~Hz}\right.$, az egyik 4- $\left.\mathrm{H}_{2}\right), 2.96\left(\mathrm{~d}, 1 \mathrm{H}, J=16.0 \mathrm{~Hz}\right.$, a másik $\left.1-\mathrm{H}_{2}\right)$, $3.06\left(\mathrm{dd}, 1 \mathrm{H}, J=18.1 \mathrm{~Hz}, J=4.4 \mathrm{~Hz}\right.$, a másik 4- $\left.\mathrm{H}_{2}\right), 3.67$ (t, $\left.1 \mathrm{H}, J=8.0 \mathrm{~Hz}, 17-\mathrm{H}\right), 7.44$ (d, $\left.1 \mathrm{H}, J=8.1 \mathrm{~Hz}, 7^{\prime}-\mathrm{H}\right), 7.44\left(\mathrm{~s}, 1 \mathrm{H}, 5^{\prime}-\mathrm{H}\right), 7.70\left(\mathrm{~s}, 1 \mathrm{H}, 4^{\prime}-\mathrm{H}\right), 7.88\left(\mathrm{~d}, 1 \mathrm{H}, J=8.1 \mathrm{~Hz}, 8^{\prime}-\mathrm{H}\right)$; ${ }^{13} \mathrm{C} \mathrm{NMR}\left(125 \mathrm{MHz}, \mathrm{CDCl}_{3}\right): \delta \mathrm{C}=11.1(\mathrm{C}-19), 11.6(\mathrm{C}-18), 20.9\left(\mathrm{CH}_{2}\right), 21.5\left(6^{\prime}-\mathrm{CH}_{3}\right), 23.4$ $\left(\mathrm{CH}_{2}\right), 28.6\left(\mathrm{CH}_{2}\right), 30.5\left(\mathrm{CH}_{2}\right), 31.1\left(\mathrm{CH}_{2}\right), 35.3(\mathrm{C}-10), 35.6(\mathrm{CH}), 36.7\left(\mathrm{CH}_{2}\right), 37.1\left(\mathrm{CH}_{2}\right)$, $42.2(\mathrm{CH}), 42.8(\mathrm{C}-13), 43.5\left(\mathrm{CH}_{2}\right), 50.9(\mathrm{CH}), 53.6(\mathrm{CH}), 81.8(\mathrm{C}-17), 125.6\left(\mathrm{C}-5^{\prime}\right), 127.2$ (C-4a'), $127.6\left(\mathrm{C}-8^{\prime}\right), 130.0\left(\mathrm{C}-5^{\prime}\right), 131.0\left(\mathrm{C}-7^{\prime}\right), 135.3$ (C-3'), $135.4\left(\mathrm{C}-4^{\prime}\right), 144.9\left(\mathrm{C}-8 \mathrm{a}^{\prime}\right)$, 157.2 (C-2'); ESI-MS: $390[\mathrm{M}+\mathrm{H}]^{+} ; \mathrm{C}_{27} \mathrm{H}_{35} \mathrm{NO}$.

14c: ${ }^{1} \mathrm{H}$ NMR $\left(500 \mathrm{MHz}, \mathrm{CDCl}_{3}\right): \delta_{\mathrm{H}}=0.63(\mathrm{~m}, 1 \mathrm{H}), 0.73(\mathrm{~s}, 3 \mathrm{H})$ és $0.74(\mathrm{~s}, 3 \mathrm{H}): 18-\mathrm{CH}_{3}$ és 19- $\mathrm{CH}_{3}, 0.81(\mathrm{~m}, 2 \mathrm{H}), 1.04(\mathrm{~m}, 1 \mathrm{H}), 1.22-1.56$ (átfedő $\left.\mathrm{m}, 9 \mathrm{H}\right), 1.67(\mathrm{~m}, 2 \mathrm{H}), 1.86(\mathrm{~m}$, $1 \mathrm{H}), 1.98(\mathrm{~m}, 1 \mathrm{H}), 2.43\left(\mathrm{~d}, 1 \mathrm{H}, J=16.0 \mathrm{~Hz}\right.$, az egyik 1- $\left.\mathrm{H}_{2}\right), 2.66(\mathrm{dd}, 1 \mathrm{H}, J=17.2 \mathrm{~Hz}, J=$

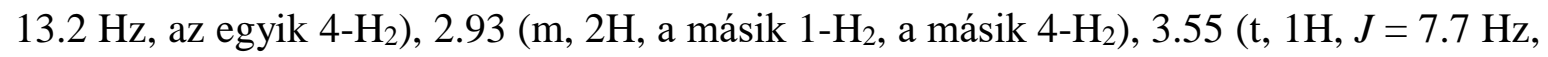
17-H), 3.90 (s, 3H, 6'-OMe), 7.14 (s, 1H, 5'-H), 7.29 (d, 1H, J=8.8 Hz, 7'-H), 7.78 (d, 1H, $\left.J=8.8 \mathrm{~Hz}, 8^{\prime}-\mathrm{H}\right), 7.88\left(\mathrm{~s}, 1 \mathrm{H}, 4^{\prime}-\mathrm{H}\right) ;{ }^{13} \mathrm{C} \mathrm{NMR}\left(125 \mathrm{MHz}, \mathrm{CDCl}_{3}\right): \delta \mathrm{C}=11.6(\mathrm{C}-19), 11.9$ (C-18), $22.0\left(\mathrm{CH}_{2}\right), 24.3\left(\mathrm{CH}_{2}\right), 29.7\left(\mathrm{CH}_{2}\right), 30.7\left(\mathrm{CH}_{2}\right), 32.2\left(\mathrm{CH}_{2}\right), 36.3(\mathrm{C}-10), 36.9(\mathrm{CH})$, $37.5\left(\mathrm{CH}_{2}\right), 38.0\left(\mathrm{CH}_{2}\right), 43.3(\mathrm{CH}), 44.0(\mathrm{C}-13), 44.4\left(\mathrm{CH}_{2}\right), 52.2(\mathrm{CH}), 55.0(\mathrm{CH}), 56.1\left(6^{\prime}-\right.$ OMe), 82.5 (C-17), 105.8 (C-5'), 123.1 (C-7'), 129.2 (C-8'), 130.0 (C-4a'), 132.1 (C-3'), $137.2\left(\mathrm{C}-4^{\prime}\right), 143.2\left(\mathrm{C}-8 \mathrm{a}^{\prime}\right), 156.5$ és 159.0 (C-2' és C-6'); ESI-MS: $406[\mathrm{M}+\mathrm{H}]^{+} ; \mathrm{C}_{27} \mathrm{H}_{35} \mathrm{NO}_{2}$.

14d: ${ }^{1} \mathrm{H}$ NMR $\left(500 \mathrm{MHz}, \mathrm{CDCl}_{3}\right): \delta_{\mathrm{H}}=0.77\left(\mathrm{~s}, 3 \mathrm{H}, 18-\mathrm{CH}_{3}\right), 0.80\left(\mathrm{~s}, 3 \mathrm{H}, 19-\mathrm{CH}_{3}\right), 0.86(\mathrm{~m}$, $1 \mathrm{H}), 0.97(\mathrm{~m}, 1 \mathrm{H}), 1.12(\mathrm{~m}, 1 \mathrm{H}), 1.25-1.52$ (átfedő $\mathrm{m}, 5 \mathrm{H}$ ), 1.60-1.77 (átfedő m, 6H), 1.88 $(\mathrm{m}, 1 \mathrm{H}), 2.08(\mathrm{~m}, 1 \mathrm{H}), 2.59(\mathrm{~d}, 1 \mathrm{H}, J=16.1 \mathrm{~Hz} \text {, az egyik 1-H })_{2}, 2.87(\mathrm{dd}, 1 \mathrm{H}, J=18.6 \mathrm{~Hz}$, $J=12.8 \mathrm{~Hz}$, az egyik 4- $\left.\mathrm{H}_{2}\right), 2.99\left(\mathrm{~d}, 1 \mathrm{H}, J=16.1 \mathrm{~Hz}\right.$, a másik $\left.1-\mathrm{H}_{2}\right), 3.20(\mathrm{dd}, 1 \mathrm{H}, J=18.6$ $\mathrm{Hz}, J=5.4 \mathrm{~Hz}$, a másik 4-H2), 3.66 (t, 1H, $J=8.5 \mathrm{~Hz}, 17-\mathrm{H}), 7.32$ (t-szerü m, 1H, 6'-H), $7.61\left(\mathrm{~d}, 1 \mathrm{H}, J=8.1 \mathrm{~Hz}, 5^{\prime}-\mathrm{H}\right), 7.71\left(\mathrm{~d}, 1 \mathrm{H}, J=7.4 \mathrm{~Hz}, 7^{\prime}-\mathrm{H}\right), 7.79\left(\mathrm{~s}, 1 \mathrm{H}, 4^{\prime}-\mathrm{H}\right) ;{ }^{13} \mathrm{C} \mathrm{NMR}$ $\left(125 \mathrm{MHz}, \mathrm{CDCl}_{3}\right): \delta_{\mathrm{C}}=11.1(\mathrm{C}-19), 11.7(\mathrm{C}-18), 20.9\left(\mathrm{CH}_{2}\right), 23.4\left(\mathrm{CH}_{2}\right), 28.5\left(\mathrm{CH}_{2}\right), 30.5$ $\left(\mathrm{CH}_{2}\right), 31.1\left(\mathrm{CH}_{2}\right), 35.3(\mathrm{C}-10), 35.6(\mathrm{CH}), 36.7\left(\mathrm{CH}_{2}\right), 37.6\left(\mathrm{CH}_{2}\right), 42.2(\mathrm{CH}), 42.8(\mathrm{C}-13)$, $43.4\left(\mathrm{CH}_{2}\right), 50.9(\mathrm{CH}), 53.6(\mathrm{CH}), 81.9(\mathrm{C}-17), 124.9$ és $125.3\left(\mathrm{C}-5^{\prime}\right.$ és C-6'), $128.5\left(\mathrm{C}-4 \mathrm{a}^{\prime}\right)$,

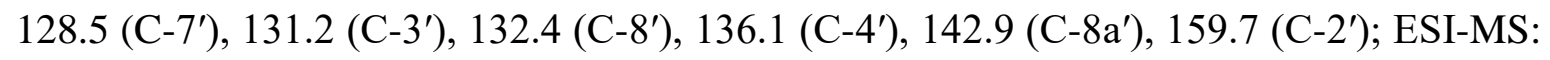
$410[\mathrm{M}+\mathrm{H}]^{+} ; \mathrm{C}_{26} \mathrm{H}_{32} \mathrm{ClNO}$.

14e: ${ }^{1} \mathrm{H}$ NMR $\left(500 \mathrm{MHz}, \mathrm{CDCl}_{3}\right): \delta_{\mathrm{H}}=0.78\left(\mathrm{~s}, 3 \mathrm{H}, 18-\mathrm{CH}_{3}\right), 0.79\left(\mathrm{~s}, 3 \mathrm{H}, 19-\mathrm{CH}_{3}\right), 0.86(\mathrm{~m}$, $1 \mathrm{H}), 0.98(\mathrm{~m}, 1 \mathrm{H}), 1.13(\mathrm{~m}, 1 \mathrm{H}), 1.26-1.51$ (átfedő $\mathrm{m}, 5 \mathrm{H}$ ), 1.57-1.73 (átfedő m, 6H), 1.87 $(\mathrm{m}, 1 \mathrm{H}), 2.06(\mathrm{~m}, 1 \mathrm{H}), 2.58(\mathrm{~d}, 1 \mathrm{H}, J=16.1 \mathrm{~Hz}$, az egyik 1-H $), 2.76(\mathrm{dd}, 1 \mathrm{H}, J=18.1 \mathrm{~Hz}$, $J=13.4 \mathrm{~Hz}$, az egyik 4- $\left.\mathrm{H}_{2}\right), 2.98\left(\mathrm{~d}, 1 \mathrm{H}, J=16.1 \mathrm{~Hz}\right.$, a másik $\left.1-\mathrm{H}_{2}\right), 3.05(\mathrm{dd}, 1 \mathrm{H}, J=18.1$ $\mathrm{Hz}, J=4.4 \mathrm{~Hz}$, a másik 4- $\left.\mathrm{H}_{2}\right), 3.67(\mathrm{t}, 1 \mathrm{H}, J=7.5 \mathrm{~Hz}, 17-\mathrm{H}), 7.53\left(\mathrm{~d}, 1 \mathrm{H}, J=8.5 \mathrm{~Hz}, 7^{\prime}-\mathrm{H}\right)$, 7.66 (s, 1H, 5'-H), 7.69 (s, 1H, 4'-H), 7.90 (d, 1H, $\left.J=8.7 \mathrm{~Hz}, 8^{\prime}-\mathrm{H}\right) ;{ }^{13} \mathrm{C}$ NMR $(125 \mathrm{MHz}$, $\left.\mathrm{CDCl}_{3}\right): \delta_{\mathrm{C}}=11.1(\mathrm{C}-19), 11.7(\mathrm{C}-18), 20.9\left(\mathrm{CH}_{2}\right), 23.4\left(\mathrm{CH}_{2}\right), 28.6\left(\mathrm{CH}_{2}\right), 30.5\left(\mathrm{CH}_{2}\right), 31.1$ $\left(\mathrm{CH}_{2}\right), 35.3(\mathrm{C}-10), 35.6(\mathrm{CH}), 36.7\left(\mathrm{CH}_{2}\right), 37.3\left(\mathrm{CH}_{2}\right), 42.2(\mathrm{CH}), 42.9(\mathrm{C}-13), 43.5\left(\mathrm{CH}_{2}\right)$, $50.9(\mathrm{CH}), 53.6(\mathrm{CH}), 81.8(\mathrm{C}-17), 125.4\left(\mathrm{C}-5^{\prime}\right), 127.8\left(\mathrm{C}-4 \mathrm{a}^{\prime}\right), 129.4$ és 129.8 (C-7' és C- 
8'), 131.1 (C-6'), 131.2 (C-3'), 134.8 (C-4'), 144.9 (C-8a'), 158.8 (C-2'); ESI-MS: 410 $[\mathrm{M}+\mathrm{H}]^{+} ; \mathrm{C}_{26} \mathrm{H}_{32} \mathrm{ClNO}$.

14f: ${ }^{1} \mathrm{H}$ NMR $\left(500 \mathrm{MHz}, \mathrm{CDCl}_{3}\right): \delta_{\mathrm{H}}=0.77\left(\mathrm{~s}, 3 \mathrm{H}, 18-\mathrm{CH}_{3}\right), 0.79\left(\mathrm{~s}, 3 \mathrm{H}, 19-\mathrm{CH}_{3}\right), 0.86(\mathrm{~m}$, $1 \mathrm{H}), 0.97(\mathrm{~m}, 1 \mathrm{H}), 1.12(\mathrm{~m}, 1 \mathrm{H}), 1.24-1.51$ (átfedő $\mathrm{m}, 5 \mathrm{H}$ ), 1.60-1.76 (átfedő m, 6H), 1.88 $(\mathrm{m}, 1 \mathrm{H}), 2.07(\mathrm{~m}, 1 \mathrm{H}), 2.58(\mathrm{~d}, 1 \mathrm{H}, J=16.2 \mathrm{~Hz} \text {, az egyik 1-H })_{2}, 2.75(\mathrm{dd}, 1 \mathrm{H}, J=18.4 \mathrm{~Hz}$, $J=12.8 \mathrm{~Hz}$, az egyik 4- $\left.\mathrm{H}_{2}\right), 2.97\left(\mathrm{~d}, 1 \mathrm{H}, J=16.2 \mathrm{~Hz}\right.$, a másik $\left.1-\mathrm{H}_{2}\right), 3.04(\mathrm{dd}, 1 \mathrm{H}, J=18.4$ $\mathrm{Hz}, J=5.3 \mathrm{~Hz}$, a másik 4-H $\mathrm{H}_{2}, 3.67$ (t, $\left.1 \mathrm{H}, J=8.4 \mathrm{~Hz}, 17-\mathrm{H}\right), 7.65\left(\mathrm{~d}, 1 \mathrm{H}, J=9.0 \mathrm{~Hz}, 7^{\prime}-\mathrm{H}\right)$, 7.69 (s, 1H, 5'-H), 7.83 (d, 1H, $\left.J=9.0 \mathrm{~Hz}, 8^{\prime}-\mathrm{H}\right), 7.84$ (s, 1H, $\left.4{ }^{\prime}-\mathrm{H}\right) ;{ }^{13} \mathrm{C}$ NMR $(125 \mathrm{MHz}$, $\left.\mathrm{CDCl}_{3}\right): \delta \mathrm{C}=11.1(\mathrm{C}-19), 11.7(\mathrm{C}-18), 20.9\left(\mathrm{CH}_{2}\right), 23.4\left(\mathrm{CH}_{2}\right), 28.5\left(\mathrm{CH}_{2}\right), 30.5\left(\mathrm{CH}_{2}\right), 31.1$ $\left(\mathrm{CH}_{2}\right), 35.3(\mathrm{C}-10), 35.6(\mathrm{CH}), 36.7\left(\mathrm{CH}_{2}\right), 37.2\left(\mathrm{CH}_{2}\right), 42.1(\mathrm{CH}), 42.8(\mathrm{C}-13), 43.5\left(\mathrm{CH}_{2}\right)$, $50.9(\mathrm{CH}), 53.6(\mathrm{CH}), 81.8(\mathrm{C}-17), 119.2\left(\mathrm{C}^{6} 6^{\prime}\right), 128.3\left(\mathrm{C}-4 \mathrm{a}^{\prime}\right), 128.8\left(\mathrm{C}-5{ }^{\prime}\right), 129.9\left(\mathrm{C}-8^{\prime}\right)$,

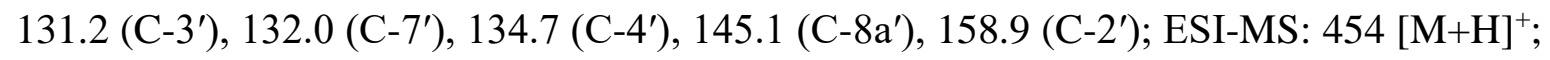
$\mathrm{C}_{26} \mathrm{H}_{32} \mathrm{BrNO}$.

14g: ${ }^{1} \mathrm{H}$ NMR $\left(500 \mathrm{MHz}, \mathrm{CDCl}_{3}\right): \delta_{\mathrm{H}}=0.77\left(\mathrm{~s}, 3 \mathrm{H}, 18-\mathrm{CH}_{3}\right), 0.79\left(\mathrm{~s}, 3 \mathrm{H}, 19-\mathrm{CH}_{3}\right), 0.85(\mathrm{~m}$, $1 \mathrm{H}), 0.98(\mathrm{~m}, 1 \mathrm{H}), 1.12(\mathrm{~m}, 1 \mathrm{H}), 1.24-1.51$ (átfedő m, 5H), 1.60-1.77 (átfedő m, 6H), 1.87 $(\mathrm{m}, 1 \mathrm{H}), 2.07(\mathrm{~m}, 1 \mathrm{H}), 2.56(\mathrm{~d}, 1 \mathrm{H}, J=16.1 \mathrm{~Hz} \text {, az egyik 1-H })_{2}, 2.75(\mathrm{dd}, 1 \mathrm{H}, J=18.4 \mathrm{~Hz}$, $J=12.7 \mathrm{~Hz}$, az egyik 4-H $\mathrm{H}_{2}, 2.96\left(\mathrm{~d}, 1 \mathrm{H}, J=16.1 \mathrm{~Hz}\right.$, a másik 1- $\left.\mathrm{H}_{2}\right), 3.05(\mathrm{dd}, 1 \mathrm{H}, J=18.4$ $\mathrm{Hz}, J=5.3 \mathrm{~Hz}$, a másik 4- $\left.\mathrm{H}_{2}\right), 3.67(\mathrm{t}, 1 \mathrm{H}, J=8.4 \mathrm{~Hz}, 17-\mathrm{H}), 7.37\left(\mathrm{~d}, 1 \mathrm{H}, J=8.7 \mathrm{~Hz}, 6^{\prime}-\mathrm{H}\right)$, 7.61 (d, 1H, $\left.J=8.7 \mathrm{~Hz}, 5^{\prime}-\mathrm{H}\right), 7.76$ (s, 1H, 4'-H), 7.97 (s, 1H, 8'-H); ${ }^{13} \mathrm{C}$ NMR $(125 \mathrm{MHz}$, $\left.\mathrm{CDCl}_{3}\right): \delta_{\mathrm{C}}=11.1(\mathrm{C}-19), 11.7(\mathrm{C}-18), 20.9\left(\mathrm{CH}_{2}\right), 23.4\left(\mathrm{CH}_{2}\right), 28.5\left(\mathrm{CH}_{2}\right), 30.5\left(\mathrm{CH}_{2}\right), 31.1$ $\left(\mathrm{CH}_{2}\right), 35.3(\mathrm{C}-10), 35.6(\mathrm{CH}), 36.7\left(\mathrm{CH}_{2}\right), 37.3\left(\mathrm{CH}_{2}\right), 42.1(\mathrm{CH}), 42.8(\mathrm{C}-13), 43.5\left(\mathrm{CH}_{2}\right)$, $50.9(\mathrm{CH}), 53.6(\mathrm{CH}), 81.8(\mathrm{C}-17), 125.5\left(\mathrm{C}^{\left.-4 a^{\prime}\right),} 126.6\left(\mathrm{C}-6^{\prime}\right), 127.2\left(\mathrm{C}-8^{\prime}\right), 128.0\left(\mathrm{C}-5^{\prime}\right)\right.$,

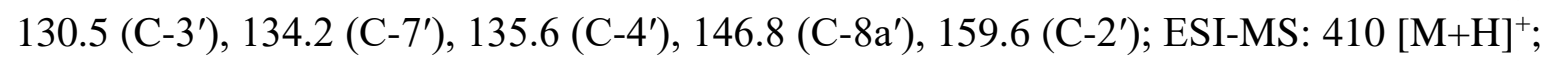
$\mathrm{C}_{26} \mathrm{H}_{32} \mathrm{CINO}$.

14g': ${ }^{1} \mathrm{H}$ NMR $\left(500 \mathrm{MHz}, \mathrm{CDCl}_{3}\right): \delta_{\mathrm{H}}=0.78\left(\mathrm{~s}, 3 \mathrm{H}, 18-\mathrm{CH}_{3}\right), 0.80\left(\mathrm{~s}, 3 \mathrm{H}, 19-\mathrm{CH}_{3}\right), 0.87$ $(\mathrm{m}, 1 \mathrm{H}), 0.98(\mathrm{~m}, 1 \mathrm{H}), 1.13(\mathrm{~m}, 1 \mathrm{H}), 1.25-1.52$ (átfedő m, 5H), 1.59-1.77 (átfedő m, 6H), $1.88(\mathrm{~m}, 1 \mathrm{H}), 2.07(\mathrm{~m}, 1 \mathrm{H}), 2.63\left(\mathrm{~d}, 1 \mathrm{H}, J=16.2 \mathrm{~Hz}\right.$, az egyik $\left.1-\mathrm{H}_{2}\right), 2.79(\mathrm{dd}, 1 \mathrm{H}, J=18.4$

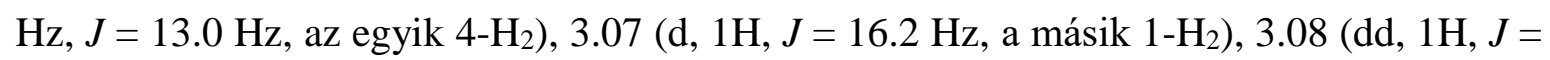
$18.4 \mathrm{~Hz}, J=5.6 \mathrm{~Hz}$, a másik 4-H $\mathrm{H}_{2}, 3.67$ (t, $\left.1 \mathrm{H}, J=7.4 \mathrm{~Hz}, 17-\mathrm{H}\right), 7.50$ (m, 2H, 6'-H és 7'$\mathrm{H}), 7.90\left(\mathrm{~m}, 1 \mathrm{H}, 8^{\prime}-\mathrm{H}\right), 8.20\left(\mathrm{~s}, 1 \mathrm{H}, 4{ }^{\prime}-\mathrm{H}\right) ;{ }^{13} \mathrm{C} \mathrm{NMR}\left(125 \mathrm{MHz}, \mathrm{CDCl}_{3}\right): \delta_{\mathrm{C}}=11.1(\mathrm{C}-19)$, 11.7 (C-18), $20.9\left(\mathrm{CH}_{2}\right), 23.4\left(\mathrm{CH}_{2}\right), 28.5\left(\mathrm{CH}_{2}\right), 30.5\left(\mathrm{CH}_{2}\right), 31.1\left(\mathrm{CH}_{2}\right), 35.3(\mathrm{C}-10), 35.6$ $(\mathrm{CH}), 36.7\left(\mathrm{CH}_{2}\right), 37.1\left(\mathrm{CH}_{2}\right), 42.2(\mathrm{CH}), 42.9(\mathrm{C}-13), 43.7\left(\mathrm{CH}_{2}\right), 50.9(\mathrm{CH}), 53.6(\mathrm{CH})$, 81.8 (C-17), 125.3 (C-4a'), 125.5, 127.4 és 128.2 (C-6', C-7' és C-8'), 130.4 (C-5'), 131.3 (C-3'), $132.6\left(\mathrm{C}-4^{\prime}\right), 147.2\left(\mathrm{C}-8 \mathrm{a}^{\prime}\right), 159.3\left(\mathrm{C}-2^{\prime}\right)$; ESI-MS: $410[\mathrm{M}+\mathrm{H}]^{+} ; \mathrm{C}_{26} \mathrm{H}_{32} \mathrm{CINO}$.

14h: ${ }^{1} \mathrm{H}$ NMR $\left(500 \mathrm{MHz}, \mathrm{CDCl}_{3}\right): \delta_{\mathrm{H}}=0.77\left(\mathrm{~s}, 3 \mathrm{H}, 18-\mathrm{CH}_{3}\right), 0.81\left(\mathrm{~s}, 3 \mathrm{H}, 19-\mathrm{CH}_{3}\right), 0.87(\mathrm{~m}$, $1 \mathrm{H}), 0.98(\mathrm{~m}, 1 \mathrm{H}), 1.13(\mathrm{~m}, 1 \mathrm{H}), 1.25-1.51$ (átfedő $\mathrm{m}, 6 \mathrm{H}), 1.60-1.77$ (átfedő $\mathrm{m}, 5 \mathrm{H}), 1.87$ $(\mathrm{m}, 1 \mathrm{H}), 2.08(\mathrm{~m}, 1 \mathrm{H}), 2.58(\mathrm{~d}, 1 \mathrm{H}, J=16.0 \mathrm{~Hz}$, az egyik 1-H $), 2.79\left(\mathrm{~s}, 3 \mathrm{H}, 8^{\prime}-\mathrm{CH}_{3}\right), 2.83$ $\left(\mathrm{dd}, 1 \mathrm{H}, J=18.2 \mathrm{~Hz}, J=12.7 \mathrm{~Hz}\right.$, az egyik 4- $\left.\mathrm{H}_{2}\right), 2.97\left(\mathrm{~d}, 1 \mathrm{H}, J=16.0 \mathrm{~Hz}\right.$, a másik 1- $\left.\mathrm{H}_{2}\right)$, $3.14(\mathrm{~m}, 1 \mathrm{H}$, a másik 4-H2), $3.65(\mathrm{~m}, 1 \mathrm{H}, 17-\mathrm{H}), 7.32$ (t-szerü m, 1H, 6'-H), $7.45(\mathrm{~d}, 1 \mathrm{H}, J=$ $\left.6.8 \mathrm{~Hz}, 7^{\prime}-\mathrm{H}\right), 7.54\left(\mathrm{~d}, 1 \mathrm{H}, J=8.0 \mathrm{~Hz}, 5^{\prime}-\mathrm{H}\right), 7.77$ (s, $\left.1 \mathrm{H}, 4^{\prime}-\mathrm{H}\right) ;{ }^{13} \mathrm{C} \mathrm{NMR}\left(125 \mathrm{MHz}, \mathrm{CDCl}_{3}\right)$ : $\delta_{\mathrm{C}}=11.1(\mathrm{C}-19), 11.7(\mathrm{C}-18), 18.1\left(8^{\prime}-\mathrm{CH}_{3}\right), 20.9\left(\mathrm{CH}_{2}\right), 23.4\left(\mathrm{CH}_{2}\right), 28.6\left(\mathrm{CH}_{2}\right), 29.7$ 
$\left(\mathrm{CH}_{2}\right), 30.5\left(\mathrm{CH}_{2}\right), 31.2\left(\mathrm{CH}_{2}\right), 35.3(\mathrm{C}-10), 35.6(\mathrm{CH}), 36.7\left(\mathrm{CH}_{2}\right), 42.3(\mathrm{CH}), 42.8(\mathrm{C}-13)$, $43.4\left(\mathrm{CH}_{2}\right), 50.9(\mathrm{CH}), 53.6(\mathrm{CH}), 81.9(\mathrm{C}-17), 124.9$ és $125.3\left(\mathrm{C}-5^{\prime}\right.$ és C-6'), $127.1\left(\mathrm{C}-4 \mathrm{a}^{\prime}\right)$, 128.7 (C-7'), 129.7 (C-3'), 132.1 (C-8'), 135.8 (C-4'), 136.0 (C-8a'), 157.3 (C-2'); ESI-MS: $390[\mathrm{M}+\mathrm{H}]^{+} ; \mathrm{C}_{27} \mathrm{H}_{35} \mathrm{NO}$.

15: ${ }^{1} \mathrm{H}$ NMR $\left(500 \mathrm{MHz}, \mathrm{CDCl}_{3}\right): \delta_{\mathrm{H}}=0.81(\mathrm{~s}, 3 \mathrm{H}), 0.82(\mathrm{~s}+\mathrm{m}, 4 \mathrm{H}): 18-\mathrm{H}_{3}, 19-\mathrm{H}_{3}$ és $1 \mathrm{H}$, $0.94(\mathrm{~m}, 1 \mathrm{H}), 1.06(\mathrm{~m}, 1 \mathrm{H}), 1.14-1.25$ (átfedő $\mathrm{m}, 2 \mathrm{H}), 1.32(\mathrm{~m}, 1 \mathrm{H}), 1.41(\mathrm{~m}, 2 \mathrm{H}), 1.46-1.54$ (átfedő m, 2H), 1.58-1.68 (átfedő m, 3H), $1.72(\mathrm{~m}, 1 \mathrm{H}), 1.79$ (m, 1H), 2.04 (s, 3H, Ac- $\mathrm{CH}_{3}$ ), 2.09-2.18 (átfedő m, 2H, az egyik 4- $\mathrm{H}_{2}$ és $1 \mathrm{H}$ ), $2.22\left(\mathrm{~d}, 1 \mathrm{H}, J=14.7 \mathrm{~Hz}\right.$, az egyik $\left.1-\mathrm{H}_{2}\right)$, $2.35\left(\mathrm{dd}, 1 \mathrm{H}, J=19.2 \mathrm{~Hz}, J=5.6 \mathrm{~Hz}\right.$, a másik 4- $\left.\mathrm{H}_{2}\right), 2.42(\mathrm{~d}, 1 \mathrm{H}, J=14.7 \mathrm{~Hz}$, a másik 1$\mathrm{H}_{2}$ ), 4.61 (t-szerü m, 1H, 17-H), 7.03 (d, 2H, $J=9.1 \mathrm{~Hz}, 2^{\prime}$-H és 6'-H), 7.09 (d, 1H, $J=11.3$ $\mathrm{Hz}, \underline{\mathrm{CH}}-\mathrm{OH}), 8.18$ (d, 2H, $J=9.1 \mathrm{~Hz}, 3^{\prime}-\mathrm{H}$ és $\left.5^{\prime}-\mathrm{H}\right), 11.98(\mathrm{~d}, 1 \mathrm{H}, J=11.3 \mathrm{~Hz}, \mathrm{OH}) ;{ }^{13} \mathrm{C}$ NMR $\left(125 \mathrm{MHz}, \mathrm{CDCl}_{3}\right): \delta_{\mathrm{C}}=11.5(\mathrm{C}-19), 12.0(\mathrm{C}-18), 20.8\left(\mathrm{CH}_{2}\right), 21.2\left(\mathrm{Ac}_{-} \mathrm{CH}_{3}\right), 23.5$ $\left(\mathrm{CH}_{2}\right), 27.5\left(\mathrm{CH}_{2}\right), 28.2\left(\mathrm{CH}_{2}\right), 31.0\left(\mathrm{CH}_{2}\right), 35.3(\mathrm{CH}), 35.7(\mathrm{C}-10), 36.8\left(\mathrm{CH}_{2}\right), 41.7(\mathrm{CH})$, 42.3 (C-13), 42.4 (C-4), 42.5 (C-1), 50.7 (CH), $53.1(\mathrm{CH}), 82.7$ (C-17), 108.2 (C-2), 112.5 (C-3), 114.7 (2C, C-2' és C-6'), 126.0 (2C, C-3' és C-5'), 139.4 ( $\underline{\mathrm{CH}}-\mathrm{OH}), 142.2\left(\mathrm{C}-1^{\prime}\right), 146.2$ (C-4'), 171.2 (Ac-CO); ESI-MS: $503[\mathrm{M}+\mathrm{Na}]^{+} ; \mathrm{C}_{28} \mathrm{H}_{36} \mathrm{~N}_{2} \mathrm{O}_{5}$.

19b: IR $\left(\mathrm{cm}^{-1}\right): 3485(\mathrm{OH}), 1601(\mathrm{Ph} \mathrm{C}=\mathrm{C}), 1533(\mathrm{C}=\mathrm{N}), 1520(\mathrm{Ph} \mathrm{C}=\mathrm{C}), 1055,1040(\mathrm{C}-\mathrm{O})$. ${ }^{1} \mathrm{H} \mathrm{NMR}\left(\mathrm{CDCl}_{3}, 500 \mathrm{MHz}\right): \delta 1.04\left(\mathrm{~s}, 3 \mathrm{H}, 18-\mathrm{CH}_{3}\right), 1.06\left(\mathrm{~s}, 3 \mathrm{H}, 19-\mathrm{CH}_{3}\right), 1.10(\mathrm{~m}, 2 \mathrm{H})$, 1.45-2.31 (átfedő m, 14H), $2.38\left(\mathrm{~s}, 3 \mathrm{H}, 4^{\prime \prime}-\mathrm{CH}_{3}\right), 2.56(\mathrm{dd}, 1 \mathrm{H}, J=13.6 \mathrm{~Hz}, J=6.1 \mathrm{~Hz}, \mathrm{az}$ egyik 15- $\left.\mathrm{H}_{2}\right), 3.51(\mathrm{~m}, 1 \mathrm{H}, 3-\mathrm{H}), 5.38(\mathrm{~m}, 1 \mathrm{H}, 6-\mathrm{H}), 7.22$ (d, 2H, J = 7.9 Hz, 2"-H és 6"-H), $7.37\left(\mathrm{~s}, 1 \mathrm{H}, 3^{\prime}-\mathrm{H}\right), 7.38\left(\mathrm{~d}, 2 \mathrm{H}, J=7.9 \mathrm{~Hz}, 3^{\prime \prime}\right.$ - és $\left.5^{\prime \prime}-\mathrm{H}\right) ;{ }^{13} \mathrm{C} \mathrm{NMR}\left(\mathrm{CDCl}_{3}, 125 \mathrm{MHz}\right): \delta$ 17.5 (C-18), $19.3(\mathrm{C}-19), 20.3\left(\mathrm{CH}_{2}\right), 21.0\left(4 "-\mathrm{CH}_{3}\right), 24.2\left(\mathrm{CH}_{2}\right), 30.7(\mathrm{CH}), 31.2\left(\mathrm{CH}_{2}\right)$, $31.5\left(\mathrm{CH}_{2}\right), 34.7\left(\mathrm{CH}_{2}\right), 36.6(\mathrm{C}-10), 37.0\left(\mathrm{CH}_{2}\right), 42.2\left(\mathrm{CH}_{2}\right), 42.3(\mathrm{C}-13), 50.2(\mathrm{CH}), 63.0$ (CH), 71.5 (C-3), 121.0 (C-6), 123.5 (2C, C-2" és C-6"), 125.8 (C-16), 129.4 (2C, C-3" és C-5"), 135.0 (C-3'), 137.2 és 137.7: C-1" és C-4", 141.0 (C-5), 157.2 (C-17); ESI-MS: 403 $[\mathrm{M}+\mathrm{H}]^{+} ; \mathrm{C}_{27} \mathrm{H}_{34} \mathrm{~N}_{2} \mathrm{O}$.

19c: IR $\left(\mathrm{cm}^{-1}\right): 3358(\mathrm{OH}), 1609(\mathrm{Ph} \mathrm{C}=\mathrm{C}), 1537(\mathrm{C}=\mathrm{N}), 1519(\mathrm{Ph} \mathrm{C}=\mathrm{C}), 1048,1029(\mathrm{C}-\mathrm{O})$. ${ }^{1} \mathrm{H} \mathrm{NMR}\left(\mathrm{CDCl}_{3}, 500 \mathrm{MHz}\right): \delta 1.04\left(\mathrm{~s}, 3 \mathrm{H}, 18-\mathrm{CH}_{3}\right), 1.07\left(\mathrm{~s}, 3 \mathrm{H}, 19-\mathrm{CH}_{3}\right), 1.09(\mathrm{~m}, 2 \mathrm{H})$, 1.45-2.33 (átfedő $\mathrm{m}, 14 \mathrm{H}), 2.61\left(\mathrm{dd}, 1 \mathrm{H}, J=13.8 \mathrm{~Hz}, J=6.2 \mathrm{~Hz}\right.$, az egyik $\left.15-\mathrm{H}_{2}\right), 3.53(\mathrm{~m}$, 1H, 3-H), 3.85 (s, 3H, 4"-OMe), 5.39 (m, 1H, 6-H), 6.97 (d, 2H, J=8.9 Hz, 3"-H és 5"-H), $7.43\left(\mathrm{~d}, 2 \mathrm{H}, J=7.9 \mathrm{~Hz}, 2^{\prime \prime}\right.$ - és $\left.6^{\prime \prime}-\mathrm{H}\right), 7.46\left(\mathrm{~s}, 1 \mathrm{H}, 3^{\prime}-\mathrm{H}\right) ;{ }^{13} \mathrm{C} \mathrm{NMR}\left(\mathrm{CDCl}_{3}, 125 \mathrm{MHz}\right): \delta$ 17.5 (C-18), $19.3(\mathrm{C}-19), 20.3\left(\mathrm{CH}_{2}\right), 24.2\left(\mathrm{CH}_{2}\right), 30.7(\mathrm{CH}), 31.2\left(\mathrm{CH}_{2}\right), 31.5\left(\mathrm{CH}_{2}\right), 34.7$ $\left(\mathrm{CH}_{2}\right), 36.6(\mathrm{C}-10), 37.0\left(\mathrm{CH}_{2}\right), 42.2\left(\mathrm{CH}_{2}\right), 42.3(\mathrm{C}-13), 50.2(\mathrm{CH}), 55.5\left(4^{\prime \prime}-\mathrm{OMe}\right), 63.0$ $(\mathrm{CH}), 71.5$ (C-3), 114.0 (2C, C-3" és C-5"), 121.0 (C-6), 125.2 (2C, C-2" és C-6"), 125.4 (C-16), 133.4 (C-1"), 134.3 (C-3'), 141.0 (C-5), 157.2 (C-17), 158.8 (C-4"); ESI-MS 419 $[\mathrm{M}+\mathrm{H}]^{+} ; \mathrm{C}_{27} \mathrm{H}_{34} \mathrm{~N}_{2} \mathrm{O}_{2}$.

19d: $\mathrm{IR}\left(\mathrm{cm}^{-1}\right): 3463(\mathrm{OH}), 1534(\mathrm{C}=\mathrm{N}), 1518(\mathrm{Ph} \mathrm{C}=\mathrm{C}), 1057,1042(\mathrm{C}-\mathrm{O})$.

${ }^{1} \mathrm{H} \mathrm{NMR}\left(\mathrm{CDCl}_{3}, 500 \mathrm{MHz}\right): \delta 1.04\left(\mathrm{~s}, 3 \mathrm{H}, 18-\mathrm{CH}_{3}\right), 1.06\left(\mathrm{~s}, 3 \mathrm{H}, 19-\mathrm{CH}_{3}\right), 1.08(\mathrm{~m}, 2 \mathrm{H})$, 1.45-2.33 (átfedő $\mathrm{m}, 14 \mathrm{H}), 2.56\left(\mathrm{dd}, 1 \mathrm{H}, J=13.7 \mathrm{~Hz}, J=6.2 \mathrm{~Hz}\right.$, az egyik 15- $\left.\mathrm{H}_{2}\right), 3.51(\mathrm{~m}$, 1H, 3-H), 5.38 (m, 1H, 6-H), 7.12 (m, 2H, 3"-H és 5"-H), 7.37 (s, 1H, 3'-H), 7.46 (m, 2H, 2"- és $6 "-\mathrm{H}) ;{ }^{13} \mathrm{C} \mathrm{NMR}\left(\mathrm{CDCl}_{3}, 125 \mathrm{MHz}\right): \delta 17.6(\mathrm{C}-18), 19.3(\mathrm{C}-19), 20.4\left(\mathrm{CH}_{2}\right), 24.2$ 
$\left(\mathrm{CH}_{2}\right), 30.7(\mathrm{CH}), 31.2\left(\mathrm{CH}_{2}\right), 31.5\left(\mathrm{CH}_{2}\right), 34.8\left(\mathrm{CH}_{2}\right), 36.6(\mathrm{C}-10), 37.0\left(\mathrm{CH}_{2}\right), 42.2\left(\mathrm{CH}_{2}\right)$, $42.3(\mathrm{C}-13), 50.1(\mathrm{CH}), 63.0(\mathrm{CH}), 71.5(\mathrm{C}-3), 115.8$ (d, 2C, $J=22.9 \mathrm{~Hz}, \mathrm{C}-3$ " és C-5"), 121.0 (C-6), 125.4 (d, 2C, $J=8.5 \mathrm{~Hz}, \mathrm{C}-2^{\prime \prime}$ és C-6"), 126.1 (C-16), 135.0 (C-3'), 136.4 (C1"), 141.0 (C-5), 157.3 (C-17), 161.7 (d, $J=246.8 \mathrm{~Hz}, \mathrm{C}-4$ "); ESI-MS $407[\mathrm{M}+\mathrm{H}]^{+}$; $\mathrm{C}_{26} \mathrm{H}_{31} \mathrm{FN}_{2} \mathrm{O}$.

19e: IR $\left(\mathrm{cm}^{-1}\right): 3355(\mathrm{OH}), 1595(\mathrm{Ph} \mathrm{C}=\mathrm{C}), 1535(\mathrm{C}=\mathrm{N}), 1505(\mathrm{Ph} \mathrm{C}=\mathrm{C}), 1091,1053(\mathrm{C}-\mathrm{O})$. ${ }^{1} \mathrm{H} \mathrm{NMR}\left(\mathrm{CDCl}_{3}, 500 \mathrm{MHz}\right): \delta 1.04\left(\mathrm{~s}, 3 \mathrm{H}, 18-\mathrm{CH}_{3}\right), 1.07\left(\mathrm{~s}, 3 \mathrm{H}, 19-\mathrm{CH}_{3}\right), 1.09(\mathrm{~m}, 2 \mathrm{H})$, 1.45-2.33 (átfedő m, 14H), $2.56\left(\mathrm{dd}, 1 \mathrm{H}, J=13.7 \mathrm{~Hz}, J=6.2 \mathrm{~Hz}\right.$, az egyik $\left.15-\mathrm{H}_{2}\right), 3.51(\mathrm{~m}$, 1H, 3-H), $5.38(\mathrm{~m}, 1 \mathrm{H}, 6-\mathrm{H}), 7.40\left(\mathrm{~d}, 2 \mathrm{H}, J=8.7 \mathrm{~Hz}, 2^{\prime \prime}-\mathrm{H}\right.$ és 6"-H), $7.41\left(\mathrm{~s}, 1 \mathrm{H}, 3^{\prime}-\mathrm{H}\right), 7.45$ $\left(\mathrm{d}, 2 \mathrm{H}, J=8.7 \mathrm{~Hz}, 3^{\prime \prime}-\right.$ és 5"-H); ${ }^{13} \mathrm{C} \mathrm{NMR}\left(\mathrm{CDCl}_{3}, 125 \mathrm{MHz}\right): \delta 17.6$ (C-18), 19.3 (C-19), $20.4\left(\mathrm{CH}_{2}\right), 24.1\left(\mathrm{CH}_{2}\right), 30.7(\mathrm{CH}), 31.1\left(\mathrm{CH}_{2}\right), 31.5\left(\mathrm{CH}_{2}\right), 34.8\left(\mathrm{CH}_{2}\right), 36.6(\mathrm{C}-10), 37.0$ $\left(\mathrm{CH}_{2}\right), 42.2\left(\mathrm{CH}_{2}\right), 42.5(\mathrm{C}-13), 50.1(\mathrm{CH}), 63.1(\mathrm{CH}), 71.5(\mathrm{C}-3), 121.0(\mathrm{C}-6), 124.6(2 \mathrm{C}$, C-2" és C-6"), 126.6 (C-16), 129.1 (2C, C-3" és C-5"), 132.8 (C-4"), 135.3 (C-3'), 138.8 (C$\left.1^{\prime \prime}\right), 141.0$ (C-5), 157.2 (C-17); ESI-MS $423[\mathrm{M}+\mathrm{H}]^{+} ; \mathrm{C}_{26} \mathrm{H}_{31} \mathrm{ClN}_{2} \mathrm{O}$.

19f: IR (cm $\left.{ }^{-1}\right)$ : $3232(\mathrm{OH}), 1591(\mathrm{Ph} \mathrm{C}=\mathrm{C}), 1536(\mathrm{C}=\mathrm{N}), 1500(\mathrm{Ph} \mathrm{C}=\mathrm{C}), 1095,1053(\mathrm{C}-\mathrm{O})$. ${ }^{1} \mathrm{H} \mathrm{NMR}\left(\mathrm{CDCl}_{3}, 500 \mathrm{MHz}\right): \delta 1.05\left(\mathrm{~s}, 3 \mathrm{H}, 18-\mathrm{CH}_{3}\right), 1.07\left(\mathrm{~s}, 3 \mathrm{H}, 19-\mathrm{CH}_{3}\right), 1.09(\mathrm{~m}, 2 \mathrm{H})$, 1.45-1.72 (átfedő $\mathrm{m}, 5 \mathrm{H}$ ), 1.80-1.88 (átfedő $\mathrm{m}, 3 \mathrm{H}$ ), 2.03-2.13 (átfedő $\mathrm{m}, 3 \mathrm{H}$ ), 2.21-2.24 (átfedő $\mathrm{m}, 3 \mathrm{H}), 2.56\left(\mathrm{dd}, 1 \mathrm{H}, J=13.8 \mathrm{~Hz}, J=6.2 \mathrm{~Hz}\right.$, az egyik $\left.15-\mathrm{H}_{2}\right), 3.52(\mathrm{~m}, 1 \mathrm{H}, 3-\mathrm{H})$, $5.38(\mathrm{~m}, 1 \mathrm{H}, 6-\mathrm{H}), 7.40\left(\mathrm{~s}, 1 \mathrm{H}, 3^{\prime}-\mathrm{H}\right.$ és d, 2H, $J=8.7 \mathrm{~Hz}, 2^{\prime \prime}-\mathrm{H}$ és 6"-H), $7.56(\mathrm{~d}, 2 \mathrm{H}, J=8.7$ $\mathrm{Hz}, 3$ "- és 5"-H); ${ }^{13} \mathrm{C} \mathrm{NMR}\left(\mathrm{CDCl}_{3}, 125 \mathrm{MHz}\right): \delta 17.6$ (C-18), $19.3(\mathrm{C}-19), 20.4\left(\mathrm{CH}_{2}\right), 24.1$ $\left(\mathrm{CH}_{2}\right), 30.7(\mathrm{CH}), 31.1\left(\mathrm{CH}_{2}\right), 31.5\left(\mathrm{CH}_{2}\right), 34.8\left(\mathrm{CH}_{2}\right), 36.6(\mathrm{C}-10), 37.0\left(\mathrm{CH}_{2}\right), 42.2\left(\mathrm{CH}_{2}\right)$, $42.6(\mathrm{C}-13), 50.1(\mathrm{CH}), 63.1(\mathrm{CH}), 71.5(\mathrm{C}-3), 120.8(\mathrm{C}-4 "), 121.0(\mathrm{C}-6), 124.9\left(2 \mathrm{C}, \mathrm{C}-2^{\prime \prime}\right.$ és C-6"), 126.7 (C-16), 132.1 (2C, C-3" és C-5"), 135.3 (C-3'), 139.1 (C-1"), 141.0 (C-5), 157.3 (C-17); ESI-MS $467[\mathrm{M}+\mathrm{H}]^{+} ; \mathrm{C}_{26} \mathrm{H}_{31} \mathrm{BrN}_{2} \mathrm{O}$.

19g: IR $\left(\mathrm{cm}^{-1}\right)$ : $3305(\mathrm{OH}), 2228(\mathrm{C} \equiv \mathrm{N}), 1605(\mathrm{Ph} \mathrm{C}=\mathrm{C}), 1537(\mathrm{C}=\mathrm{N}), 1513(\mathrm{Ph} \mathrm{C}=\mathrm{C}), 1051$ (C-O).

${ }^{1} \mathrm{H}$ NMR $\left(\mathrm{CDCl}_{3}, 500 \mathrm{MHz}\right): \delta 1.07\left(\mathrm{~s}, 3 \mathrm{H}, 18-\mathrm{CH}_{3}\right), 1.11(\mathrm{~m}, 2 \mathrm{H}), 1.13\left(\mathrm{~s}, 3 \mathrm{H}, 19-\mathrm{CH}_{3}\right)$, 1.47-1.72 (átfedő m, 5H), 1.82-1.91 (átfedő m, 3H), 2.06-2.16 (átfedő m, 3H), 2.23-2.35 (átfedő $\mathrm{m}, 3 \mathrm{H}), 2.59$ (dd, $1 \mathrm{H}, J=13.4 \mathrm{~Hz}, J=6.2 \mathrm{~Hz}$, az egyik $\left.15-\mathrm{H}_{2}\right), 3.54(\mathrm{~m}, 1 \mathrm{H}, 3-\mathrm{H})$, 5.39 (m, 1H, 6-H), 7.47 (s, 1H, 3'-H), 7.68 (d, 2H, $J=8.5 \mathrm{~Hz}, 2^{\prime \prime}-\mathrm{H}$ és 6"-H), 7.75 (d, 2H, $J$ $=8.5 \mathrm{~Hz}, 3^{\prime \prime}$ - és 5"-H); ESI-MS $414[\mathrm{M}+\mathrm{H}]^{+} ; \mathrm{C}_{27} \mathrm{H}_{31} \mathrm{~N}_{3} \mathrm{O}$.

19h: IR (cm $\left.{ }^{-1}\right): 3312(\mathrm{OH}), 1594(\mathrm{Ph} \mathrm{C}=\mathrm{C}), 1540(\mathrm{C}=\mathrm{N}) 1519(\mathrm{Ph} \mathrm{C}=\mathrm{C}), 1504(\mathrm{~N}=\mathrm{O}), 1377$ $(\mathrm{N}=\mathrm{O}), 1052,1041(\mathrm{C}-\mathrm{O})$.

${ }^{1} \mathrm{H} \mathrm{NMR}\left(\mathrm{CDCl}_{3}, 500 \mathrm{MHz}\right): \delta 1.06\left(\mathrm{~s}, 3 \mathrm{H}, 18-\mathrm{CH}_{3}\right), 1.10(\mathrm{~m}, 2 \mathrm{H}), 1.14\left(\mathrm{~s}, 3 \mathrm{H}, 19-\mathrm{CH}_{3}\right)$, 1.46-1.72 (átfedő m, 5H), 1.80-1.91 (átfedő m, 3H), 2.06-2.33 (átfedő m, 3H), 2.58 (dd, 1H, $J=13.8 \mathrm{~Hz}, J=6.2 \mathrm{~Hz}$, az egyik 15- $\left.\mathrm{H}_{2}\right), 3.53(\mathrm{~m}, 1 \mathrm{H}, 3-\mathrm{H}), 5.38(\mathrm{~m}, 1 \mathrm{H}, 6-\mathrm{H}), 7.47(\mathrm{~s}, 1 \mathrm{H}$, $\left.3^{\prime}-\mathrm{H}\right), 7.72\left(\mathrm{~d}, 2 \mathrm{H}, J=8.8 \mathrm{~Hz}, 2^{\prime \prime}-\mathrm{H}\right.$ és $\left.6 "-\mathrm{H}\right), 8.32$ (d, 2H, $J=8.8 \mathrm{~Hz}, 3^{\prime \prime}$ - és $\left.5^{\prime \prime}-\mathrm{H}\right) ;{ }^{13} \mathrm{C} \mathrm{NMR}$ $\left(\mathrm{CDCl}_{3}, 125 \mathrm{MHz}\right): \delta 17.5(\mathrm{C}-18), 19.3(\mathrm{C}-19), 20.4\left(\mathrm{CH}_{2}\right), 24.0\left(\mathrm{CH}_{2}\right), 30.7(\mathrm{CH}), 31.1$ $\left(\mathrm{CH}_{2}\right), 31.5\left(\mathrm{CH}_{2}\right), 35.0\left(\mathrm{CH}_{2}\right), 36.6(\mathrm{C}-10), 37.0\left(\mathrm{CH}_{2}\right), 42.2\left(\mathrm{CH}_{2}\right), 43.1(\mathrm{C}-13), 50.0(\mathrm{CH})$, $63.2(\mathrm{CH}), 71.5$ (C-3), 120.9 (C-6), 122.5 (2C, C-2" és C-6"), 124.8 (2C, C-3" és C-5"), 
128.5 (C-16), 136.9 (C-3'), 141.0 (C-5), 145.0 és 145.8: C-1" és C-1", 157.5 (C-17); ESIMS $434[\mathrm{M}+\mathrm{H}]^{+} ; \mathrm{C}_{26} \mathrm{H}_{31} \mathrm{~N}_{3} \mathrm{O}_{3}$.

20a: IR $\left(\mathrm{cm}^{-1}\right): 3287(\mathrm{OH}), 1599(\mathrm{Ph} \mathrm{C}=\mathrm{C}), 1581(\mathrm{C}=\mathrm{N}), 1507(\mathrm{Ph} \mathrm{C}=\mathrm{C}), 1054,1036(\mathrm{C}-\mathrm{O})$. ${ }^{1} \mathrm{H} \mathrm{NMR}\left(\mathrm{CDCl}_{3}, 500 \mathrm{MHz}\right): \delta 1.09$ (s, 3H) és $1.10(\mathrm{~s}, 3 \mathrm{H}): 18-\mathrm{H}_{3}$ és $19-\mathrm{H}_{3}, 1.12-2.43$ (átfedő m, 16H), $2.62\left(\mathrm{dd}, 1 \mathrm{H}, J=14.1 \mathrm{~Hz}, J=5.8 \mathrm{~Hz}\right.$, az egyik 15- $\left.\mathrm{H}_{2}\right), 3.54(\mathrm{~m}, 1 \mathrm{H}, 3-\mathrm{H})$, 5.39 (m, 1H, 6-H), 7.20 (m, 1H, 4"-H), 7.39 (m, 2H, 3"-H és 5"-H), 7.51 (s, 1H, 5'-H), 7.61 $\left(\mathrm{d}, 2 \mathrm{H}, J=7.6 \mathrm{~Hz}, 2^{\prime \prime}-\mathrm{H}\right.$ és 6"-H); ${ }^{13} \mathrm{C} \mathrm{NMR}\left(\mathrm{CDCl}_{3}, 125 \mathrm{MHz}\right)$ : $\square 18.0(\mathrm{C}-18), 19.4(\mathrm{C}-$ 19), $20.6\left(\mathrm{CH}_{2}\right), 24.2\left(\mathrm{CH}_{2}\right), 30.9(\mathrm{CH}), 31.4\left(\mathrm{CH}_{2}\right), 31.6\left(\mathrm{CH}_{2}\right), 33.9\left(\mathrm{CH}_{2}\right), 36.8(\mathrm{C}-10)$, $37.2\left(\mathrm{CH}_{2}\right), 40.7(\mathrm{C}-13), 42.3\left(\mathrm{CH}_{2}\right), 50.5(\mathrm{CH}), 62.0(\mathrm{CH}), 71.6(\mathrm{C}-3), 119.0(2 \mathrm{C}, \mathrm{C}-2$ " és C-6"), 121.0 (2C, C-6 és C-5'), 124.4 (C-16), 125.4 (C-4"), 129.3 (2C, C-3" és C-5"), 140.8 (C-1"), 141.2 (C-5), 170.8 (C-17); ESI-MS: $389[\mathrm{M}+\mathrm{H}]^{+} ; \mathrm{C}_{26} \mathrm{H}_{32} \mathrm{~N}_{2} \mathrm{O}$.

20b: IR ( $\left.\mathrm{cm}^{-1}\right): 3439(\mathrm{OH}), 1589(\mathrm{Ph} \mathrm{C}=\mathrm{C}), 1577(\mathrm{C}=\mathrm{N}), 1519$ (Ph C=C), 1069, $1026(\mathrm{C}-\mathrm{O})$. ${ }^{1} \mathrm{H} \mathrm{NMR}\left(\mathrm{CDCl}_{3}, 500 \mathrm{MHz}\right): \delta 1.09$ (s, 6H, 18- $\mathrm{H}_{3}$ és 19- $\mathrm{H}_{3}$ ), 1.12-2.35 (átfedő m, $\left.16 \mathrm{H}\right), 2.61$ (dd, $1 \mathrm{H}, J=14.2 \mathrm{~Hz}, J=5.9 \mathrm{~Hz}$, az egyik 15- $\left.\mathrm{H}_{2}\right), 3.53(\mathrm{~m}, 1 \mathrm{H}, 3-\mathrm{H}), 5.39$ (m, 1H, 6-H), 7.21 (d, 2H, $J=8.1 \mathrm{~Hz}, 2^{\prime \prime}-\mathrm{H}$ és 6"-H), 7.47 (s, 1H, 5'-H), 7.49 (d, 2H, $J=8.1 \mathrm{~Hz}, 3^{\prime \prime}$ - és 5"$\mathrm{H}) ;{ }^{13} \mathrm{C} \mathrm{NMR}\left(\mathrm{CDCl}_{3}, 125 \mathrm{MHz}\right): \delta 18.0(\mathrm{C}-18), 19.4(\mathrm{C}-19), 20.6\left(\mathrm{CH}_{2}\right), 20.8\left(4^{\prime \prime}-\mathrm{CH}_{3}\right)$, $24.2\left(\mathrm{CH}_{2}\right), 30.9(\mathrm{CH}), 31.4\left(\mathrm{CH}_{2}\right), 31.6\left(\mathrm{CH}_{2}\right), 33.9\left(\mathrm{CH}_{2}\right), 36.8(\mathrm{C}-10), 37.2\left(\mathrm{CH}_{2}\right), 40.7$ $(\mathrm{C}-13), 42.3\left(\mathrm{CH}_{2}\right), 50.6(\mathrm{CH}), 62.0(\mathrm{CH}), 71.6(\mathrm{C}-3), 119.0$ (2C, C-2" és C-6"), $121.1(2 \mathrm{C}$, C-6 és C-5'), 124.1 (C-16), 129.8 (2C, C-3" és C-5"), 135.2 (C-4"), 138.5 (C-1"), 141.2 (C5), 170.4 (C-17); ESI-MS $403[\mathrm{M}+\mathrm{H}]^{+} ; \mathrm{C}_{27} \mathrm{H}_{34} \mathrm{~N}_{2} \mathrm{O}$.

20d: IR $\left(\mathrm{cm}^{-1}\right): 3458(\mathrm{OH}), 1605(\mathrm{Ph} \mathrm{C}=\mathrm{C}), 1584(\mathrm{C}=\mathrm{N}), 1515(\mathrm{Ph} \mathrm{C}=\mathrm{C}), 1054,1041(\mathrm{C}-\mathrm{O})$. ${ }^{1} \mathrm{H} \mathrm{NMR}\left(\mathrm{CDCl}_{3}, 500 \mathrm{MHz}\right): \delta 1.10\left(\mathrm{~s}, 6 \mathrm{H}, 18-\mathrm{H}_{3}\right.$ és 19- $\left.\mathrm{H}_{3}\right), 1.13(\mathrm{~m}, 2 \mathrm{H}), 1.47-2.35$ (átfedő $\mathrm{m}, 14 \mathrm{H}), 2.63\left(\mathrm{dd}, 1 \mathrm{H}, J=14.2 \mathrm{~Hz}, J=5.9 \mathrm{~Hz}\right.$, az egyik 15- $\left.\mathrm{H}_{2}\right), 3.54(\mathrm{~m}, 1 \mathrm{H}, 3-\mathrm{H}), 5.40$ (m, 1H, 6-H), 7.09 (m, 2H, 3"-H és 5"-H), 7.45 (s, 1H, 5'-H), 7.57 (m, 2H, 2"- és 6"-H); ${ }^{13} \mathrm{C}$ NMR ( $\left.\mathrm{CDCl}_{3}, 125 \mathrm{MHz}\right): \delta 18.0(\mathrm{C}-18), 19.4(\mathrm{C}-19), 20.5\left(\mathrm{CH}_{2}\right), 24.2\left(\mathrm{CH}_{2}\right), 30.9(\mathrm{CH})$, $31.4\left(\mathrm{CH}_{2}\right), 31.6\left(\mathrm{CH}_{2}\right), 33.8\left(\mathrm{CH}_{2}\right), 36.8(\mathrm{C}-10), 37.1\left(\mathrm{CH}_{2}\right), 40.7(\mathrm{C}-13), 42.3\left(\mathrm{CH}_{2}\right), 50.5$ $(\mathrm{CH}), 61.9(\mathrm{CH}), 71.6(\mathrm{C}-3), 115.9(\mathrm{~d}, 2 \mathrm{C}, J=22.8 \mathrm{~Hz}, \mathrm{C}-3$ " és C-5"), 120.7 (d, 2C, $J=8.1$ Hz, C-2" és C-6"), 121.0 (C-6), 121.2 (C-5'), 124.5 (C-16), 137.2 (C-1"), 141.2 (C-5), 160.4 $\left(\mathrm{d}, J=245.0 \mathrm{~Hz}, \mathrm{C}-4^{\prime \prime}\right), 170.9$ (C-17); ESI-MS 407 [M+H] ${ }^{+} ; \mathrm{C}_{26} \mathrm{H}_{31} \mathrm{FN}_{2} \mathrm{O}$.

20e: IR $\left(\mathrm{cm}^{-1}\right): 3466(\mathrm{OH}), 1591(\mathrm{Ph} \mathrm{C}=\mathrm{C}), 1576(\mathrm{C}=\mathrm{N}), 1502(\mathrm{Ph} \mathrm{C}=\mathrm{C}), 1092,1057(\mathrm{C}-\mathrm{O})$. ${ }^{1} \mathrm{H} \mathrm{NMR}\left(\mathrm{CDCl}_{3}, 500 \mathrm{MHz}\right): \delta 1.09\left(\mathrm{~s}, 6 \mathrm{H}, 18-\mathrm{H}_{3}\right.$ és $\left.19-\mathrm{H}_{3}\right), 1.12(\mathrm{~m}, 2 \mathrm{H}), 1.51(\mathrm{~m}, 1 \mathrm{H})$, 1.64-2.35 (átfedő m, 13H), $2.62\left(\mathrm{dd}, 1 \mathrm{H}, J=14.3 \mathrm{~Hz}, J=5.9 \mathrm{~Hz}\right.$, az egyik $\left.15-\mathrm{H}_{2}\right), 3.53(\mathrm{~m}$, $1 \mathrm{H}, 3-\mathrm{H}), 5.39$ (m, 1H, 6-H), 7.35 (d, 2H, $J=8.8 \mathrm{~Hz}, 2^{\prime \prime}-\mathrm{H}$ és 6"-H), 7.47 (s, 1H, 5'-H), 7.55 $\left(\mathrm{d}, 2 \mathrm{H}, J=8.8 \mathrm{~Hz}, 3\right.$ "- és 5"-H); ${ }^{13} \mathrm{C} \mathrm{NMR}\left(\mathrm{CDCl}_{3}, 125 \mathrm{MHz}\right): \delta 18.0(\mathrm{C}-18), 19.4(\mathrm{C}-19)$, $20.5\left(\mathrm{CH}_{2}\right), 24.2\left(\mathrm{CH}_{2}\right), 30.9(\mathrm{CH}), 31.4\left(\mathrm{CH}_{2}\right), 31.6\left(\mathrm{CH}_{2}\right), 33.8\left(\mathrm{CH}_{2}\right), 36.8(\mathrm{C}-10), 37.2$ $\left(\mathrm{CH}_{2}\right), 40.7(\mathrm{C}-13), 42.3\left(\mathrm{CH}_{2}\right), 50.5(\mathrm{CH}), 61.9(\mathrm{CH}), 71.6(\mathrm{C}-3), 120.0$ (2C, C-2" és C-6"), 121.0 (2C, C-6 és C-5'), 124.9 (C-16), 129.3 (2C, C-3" és C-5"), 130.7 (C-4"), 139.3 (C-1"), 141.2 (C-5), 171.1 (C-17); ESI-MS $423[\mathrm{M}+\mathrm{H}]^{+} ; \mathrm{C}_{26} \mathrm{H}_{31} \mathrm{ClN}_{2} \mathrm{O}$.

20f: IR ( $\left.\mathrm{cm}^{-1}\right)$ : $3467(\mathrm{OH}), 1587(\mathrm{Ph} \mathrm{C}=\mathrm{C}), 1572(\mathrm{C}=\mathrm{N}), 1498(\mathrm{Ph} \mathrm{C}=\mathrm{C}), 1068,1056(\mathrm{C}-\mathrm{O})$. ${ }^{1} \mathrm{H} \mathrm{NMR}\left(\mathrm{CDCl}_{3}, 500 \mathrm{MHz}\right): \delta 1.09\left(\mathrm{~s}, 6 \mathrm{H}, 18-\mathrm{H}_{3}\right.$ és $\left.19-\mathrm{H}_{3}\right), 1.13(\mathrm{~m}, 2 \mathrm{H}), 1.52(\mathrm{~m}, 1 \mathrm{H})$, 
1.66-1.74 (átfedő m, 3H), 1.84-1.94 (átfedő m, 5H), 2.10 (m, 1H), 2.24-2.35 (átfedő m, 4H), $2.62\left(\mathrm{dd}, 1 \mathrm{H}, J=14.3 \mathrm{~Hz}, J=5.8 \mathrm{~Hz}\right.$, az egyik 15- $\left.\mathrm{H}_{2}\right), 3.54(\mathrm{~m}, 1 \mathrm{H}, 3-\mathrm{H}), 5.39$ (m, 1H, 6$\mathrm{H}), 7.48\left(\mathrm{~s}, 1 \mathrm{H}, 5^{\prime}-\mathrm{H}\right), 7.50$ (bs, 4H, 2"-H és 6"-H és 3"- és $\left.5^{\prime \prime}-\mathrm{H}\right) ;{ }^{13} \mathrm{C} \mathrm{NMR}\left(\mathrm{CDCl}_{3}, 125\right.$ $\mathrm{MHz}): \delta 18.1(\mathrm{C}-18), 19.4(\mathrm{C}-19), 20.6\left(\mathrm{CH}_{2}\right), 24.2\left(\mathrm{CH}_{2}\right), 30.9(\mathrm{CH}), 31.4\left(\mathrm{CH}_{2}\right), 31.6$ $\left(\mathrm{CH}_{2}\right), 33.8\left(\mathrm{CH}_{2}\right), 36.8(\mathrm{C}-10), 37.2\left(\mathrm{CH}_{2}\right), 40.7(\mathrm{C}-13), 42.3\left(\mathrm{CH}_{2}\right), 50.5(\mathrm{CH}), 61.9(\mathrm{CH})$, 71.7 (C-3), 118.3 (C-4"), 120.2 (2C, C-2" és C-6"), 120.8 (C-5'), 121.0 (C-6), 124.9 (C-16), 132.2 (2C, C-3" és C-5"), 139.9 (C-1"), 141.2 (C-5), 171.2 (C-17); ESI-MS 467 [M+H] ; $\mathrm{C}_{26} \mathrm{H}_{31} \mathrm{BrN}_{2} \mathrm{O}$.

20g: ${ }^{1} \mathrm{H}$ NMR $\left(\mathrm{CDCl}_{3}, 500 \mathrm{MHz}\right): \delta 1.09$ (s, 6H, 18- $\mathrm{H}_{3}$ és 19- $\left.\mathrm{H}_{3}\right), 1.13(\mathrm{~m}, 2 \mathrm{H}), 1.52(\mathrm{~m}$, $1 \mathrm{H}$ ), 1.57-1.74 (átfedő m, 3H), 1.82-1.94 (átfedő m, 5H), 2.10 (m, 1H), 2.24-2.34 (átfedő m, $4 \mathrm{H}), 2.62\left(\mathrm{dd}, 1 \mathrm{H}, J=14.8 \mathrm{~Hz}, J=5.3 \mathrm{~Hz}\right.$, az egyik 15- $\left.\mathrm{H}_{2}\right), 3.54(\mathrm{~m}, 1 \mathrm{H}, 3-\mathrm{H}), 5.39(\mathrm{~m}, 1 \mathrm{H}$, 6-H), 7.56 (s, 1H, 5'-H), 7.67 (d, 2H, $J=8.7 \mathrm{~Hz}, 2^{\prime \prime}-\mathrm{H}$ és 6"-H), 7.73 (d, 2H, $J=8.7 \mathrm{~Hz}, 3^{\prime \prime}-$ és $\left.5^{\prime \prime}-\mathrm{H}\right) ;{ }^{13} \mathrm{C} \mathrm{NMR}\left(\mathrm{CDCl}_{3}, 125 \mathrm{MHz}\right): \delta 17.9(\mathrm{C}-18), 19.4(\mathrm{C}-19), 20.5\left(\mathrm{CH}_{2}\right), 24.2\left(\mathrm{CH}_{2}\right)$, $30.9(\mathrm{CH}), 31.4\left(\mathrm{CH}_{2}\right), 31.6\left(\mathrm{CH}_{2}\right), 33.8\left(\mathrm{CH}_{2}\right), 36.8(\mathrm{C}-10), 37.2\left(\mathrm{CH}_{2}\right), 40.7(\mathrm{C}-13), 42.3$ $\left(\mathrm{CH}_{2}\right), 50.5(\mathrm{CH}), 61.8(\mathrm{CH}), 71.7(\mathrm{C}-3), 118.2$ (2C, C-2" és C-6"), $118.7(\mathrm{C}-4 "), 120.7(\mathrm{C}-$ 5'), 121.0 (C-6), 126.2 (C-16), 133.2 (2C, C-3" és C-5"), 141.2 (C-5), 143.8 (C-1"), 171.2 (C-17); ESI-MS $414[\mathrm{M}+\mathrm{H}]^{+} ; \mathrm{C}_{27} \mathrm{H}_{31} \mathrm{~N}_{3} \mathrm{O}$.

22a: IR (cm $\left.{ }^{-1}\right)$ : 3382, $3321(\mathrm{OH}), 1599(\mathrm{Ph} \mathrm{C}=\mathrm{C}), 1504(\mathrm{Ph} \mathrm{C}=\mathrm{C}), 1383\left(\mathrm{CH}_{3}\right), 1081,1059$ (C-O).

${ }^{1} \mathrm{H}$ NMR $\left(\mathrm{CDCl}_{3}, 500 \mathrm{MHz}\right): \delta 0.78\left(\mathrm{~s}, 3 \mathrm{H}, 18-\mathrm{CH}_{3}\right), 0.83\left(\mathrm{~s}, 3 \mathrm{H}, 19-\mathrm{CH}_{3}\right), 2.20(\mathrm{~d}, 1 \mathrm{H}, J=$

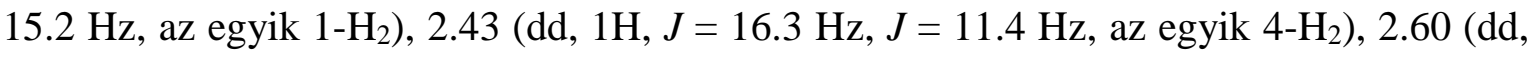
$1 \mathrm{H}, J=16.3 \mathrm{~Hz}, J=4.1 \mathrm{~Hz}$, a másik 4- $\left.\mathrm{H}_{2}\right), 2.67\left(\mathrm{~d}, 1 \mathrm{H}, J=15.2 \mathrm{~Hz}\right.$, a másik 1- $\left.\mathrm{H}_{2}\right), 3.66(\mathrm{t}$, $1 \mathrm{H}, J=8.5 \mathrm{~Hz}, 17-\mathrm{H}$ ), 7.34 (t-szerü m, 1H, 4"-H), 7.46 (t-szerü m, 2H, 3"-H és 5"-H), 7.51 (s, 1H, 3'-H), $7.53\left(\mathrm{~d}, 2 \mathrm{H}, J=8.0 \mathrm{~Hz}, 2^{\prime \prime}-\mathrm{H}\right.$ és $\left.6 "-\mathrm{H}\right) ;{ }^{13} \mathrm{C} \mathrm{NMR}\left(\mathrm{CDCl}_{3}, 125 \mathrm{MHz}\right): \delta 11.0$ (C-18), $11.5(\mathrm{C}-19), 20.7\left(\mathrm{CH}_{2}\right), 23.4\left(\mathrm{CH}_{2}\right), 27.9(\mathrm{C}-4), 29.0\left(\mathrm{CH}_{2}\right), 30.4\left(\mathrm{CH}_{2}\right), 31,2\left(\mathrm{CH}_{2}\right)$, 35.1 (C-1), 35,7 (C-5), 35.9 (C-10), 36.6 (C-16), 42.4 (C-9), 42.8 (C-13), 50.8 (C-14), 53.9 (C-8), 81.8 (C-17), 117.7 (C-2), 122.8 (2C, C-2" és C-6"), 126.7 (C-4"), 129.0 (2C, C-3" és C-5"), 137.2 (C-3), 138.9 (C-3'), 139.8 (C-1"); ESI-MS $391[\mathrm{M}+\mathrm{H}]^{+} ; \mathrm{C}_{26} \mathrm{H}_{34} \mathrm{~N}_{2} \mathrm{O}$.

22b: IR (cm $\left.{ }^{-1}\right)$ : 3401, $3273(\mathrm{OH}), 1601(\mathrm{Ph} \mathrm{C}=\mathrm{C}), 1518$ (Ph C=C), $1380\left(\mathrm{CH}_{3}\right), 1077,1057$ (C-O).

${ }^{1} \mathrm{H} \mathrm{NMR}\left(\mathrm{CDCl}_{3}, 500 \mathrm{MHz}\right): \delta 0.76\left(\mathrm{~s}, 3 \mathrm{H}, 18-\mathrm{CH}_{3}\right), 0.82\left(\mathrm{~s}, 3 \mathrm{H}, 19-\mathrm{CH}_{3}\right), 2.17(\mathrm{~d}, 1 \mathrm{H}, J=$ $15.3 \mathrm{~Hz}$, az egyik 1- $\left.\mathrm{H}_{2}\right), 2.38\left(\mathrm{~s}+\mathrm{dd}, 4 \mathrm{H}, 4^{\prime \prime}-\mathrm{CH}_{3}\right.$ és az egyik 4- $\left.\mathrm{H}_{2}\right), 2,57(\mathrm{dd}, 1 \mathrm{H}, J=16.4$ $\mathrm{Hz}, J=4.2 \mathrm{~Hz}$, a másik 4- $\left.\mathrm{H}_{2}\right), 2.63\left(\mathrm{~d}, 1 \mathrm{H}, J=15.3 \mathrm{~Hz}\right.$, a másik 1- $\left.\mathrm{H}_{2}\right), 3.64(\mathrm{t}, 1 \mathrm{H}, J=8.5$ $\mathrm{Hz}, 17-\mathrm{H}), 7.23$ (d, 2H, $J=8.1 \mathrm{~Hz}, 2^{\prime \prime}-\mathrm{H}$ és 6"-H), 7.39 (d, 2H, $J=8.1 \mathrm{~Hz}, 3$ "-H és 5"-H), $7.43\left(\mathrm{~s}, 1 \mathrm{H}, 3^{\prime}-\mathrm{H}\right) ;{ }^{13} \mathrm{C} \mathrm{NMR}\left(\mathrm{CDCl}_{3}, 125 \mathrm{MHz}\right): \delta 11,0(\mathrm{C}-18), 11.5(\mathrm{C}-19), 20.7\left(\mathrm{CH}_{2}\right)$, $21.0\left(4^{\prime \prime}-\mathrm{CH}_{3}\right), 23.4\left(\mathrm{CH}_{2}\right), 27.9(\mathrm{C}-4), 29.1\left(\mathrm{CH}_{2}\right), 30.5\left(\mathrm{CH}_{2}\right), 31.2\left(\mathrm{CH}_{2}\right), 35.2(\mathrm{C}-1), 35.7$ (C-5), 36.0 (C-10), 36.7 (C-16), 42.5 (C-9), 42.8 (C-13), 50.9 (C-14), 53.9 (C-8), 81.8 (C17), 116.9 (C-2), 122.7 (2C, C-2" és C-6"), 129.6 (2C, C-3" és C-5"), 136.5, 137.0 és 137.5: C-1", C-4" és C-3, 138.6 (C-3'); ESI-MS $405[\mathrm{M}+\mathrm{H}]^{+} ; \mathrm{C}_{27} \mathrm{H}_{36} \mathrm{~N}_{2} \mathrm{O}$.

22c: $\mathrm{IR}\left(\mathrm{cm}^{-1}\right)$ : $3331(\mathrm{OH}), 1595(\mathrm{Ph} \mathrm{C}=\mathrm{C}), 1516(\mathrm{Ph} \mathrm{C}=\mathrm{C}), 1380\left(\mathrm{CH}_{3}\right), 1056,1026(\mathrm{C}-\mathrm{O})$. ${ }^{1} \mathrm{H} \mathrm{NMR}\left(\mathrm{CDCl}_{3}, 500 \mathrm{MHz}\right): \delta 0.76\left(\mathrm{~s}, 3 \mathrm{H}, 18-\mathrm{CH}_{3}\right), 0.80$ (s, 3H, 19- $\left.\mathrm{CH}_{3}\right), 2.17(\mathrm{~d}, 1 \mathrm{H}, J=$ 


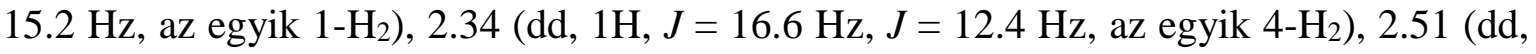
$1 \mathrm{H}, J=16.6 \mathrm{~Hz}, J=3.8 \mathrm{~Hz}$, a másik 4- $\left.\mathrm{H}_{2}\right), 2.63\left(\mathrm{~d}, 1 \mathrm{H}, J=15.2 \mathrm{~Hz}\right.$, a másik 1- $\left.\mathrm{H}_{2}\right), 3.63(\mathrm{t}$, $1 \mathrm{H}, J=8.4 \mathrm{~Hz}, 17-\mathrm{H}), 3.83\left(\mathrm{~s}, 3 \mathrm{H}, 4^{\prime \prime}-\mathrm{CH}_{3}\right), 6.95$ (d, 2H, $J=8.3 \mathrm{~Hz}, 3^{\prime \prime}-\mathrm{H}$ és 5"-H), 7.40 (d, $2 \mathrm{H}, J=8.3 \mathrm{~Hz}, 2^{\prime \prime}-\mathrm{H}$ és $\left.6 "-\mathrm{H}\right), 7.41\left(\mathrm{~s}, 1 \mathrm{H}, 33^{\prime}-\mathrm{H}\right) ;{ }^{13} \mathrm{C} \mathrm{NMR}\left(\mathrm{CDCl}_{3}, 125 \mathrm{MHz}\right): \delta 11.0(\mathrm{C}-$ 18), 11.5 (C-19), $20.7\left(\mathrm{CH}_{2}\right), 23.4\left(\mathrm{CH}_{2}\right), 27.6(\mathrm{C}-4), 29.0\left(\mathrm{CH}_{2}\right), 30.4\left(\mathrm{CH}_{2}\right), 31.2\left(\mathrm{CH}_{2}\right)$, $35.1\left(\mathrm{CH}_{2}\right), 35.7(\mathrm{C}-5), 36.0(\mathrm{C}-10), 36.6$ (C-16), 42.4 (C-9), 42.8 (C-13), 50.8 (C-14), 53.9 (C-8), 55.5 (4"-OMe), 81.8 (C-17), 114.2 (2C, C-3" és C-5"), 116.7 (C-2), 124.5 (2C, C-2" és C-6"), $133.0\left(\mathrm{C}-1^{\prime \prime}\right), 137.1$ (C-3), $138.3\left(\mathrm{C}-3^{\prime}\right), 158.3\left(\mathrm{C}-4^{\prime \prime}\right)$; ESI-MS $421[\mathrm{M}+\mathrm{H}]^{+}$; $\mathrm{C}_{27} \mathrm{H}_{36} \mathrm{~N}_{2} \mathrm{O}_{2}$.

22d: IR $\left(\mathrm{cm}^{-1}\right): 3379(\mathrm{OH}), 1605(\mathrm{Ph} \mathrm{C}=\mathrm{C}), 1583(\mathrm{C}=\mathrm{N}), 1512(\mathrm{Ph} \mathrm{C}=\mathrm{C}), 1383\left(\mathrm{CH}_{3}\right), 1076$, 1058 (C-O).

${ }^{1} \mathrm{H} \mathrm{NMR}\left(\mathrm{CDCl}_{3}, 500 \mathrm{MHz}\right): \delta 0.76\left(\mathrm{~s}, 3 \mathrm{H}, 18-\mathrm{CH}_{3}\right), 0.81\left(\mathrm{~s}, 3 \mathrm{H}, 19-\mathrm{CH}_{3}\right), 2.17(\mathrm{~d}, 1 \mathrm{H}, J=$

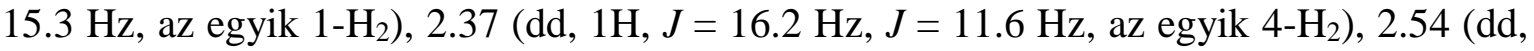
$1 \mathrm{H}, J=16.2 \mathrm{~Hz}, J=3.8 \mathrm{~Hz}$, a másik 4- $\left.\mathrm{H}_{2}\right), 2.63\left(\mathrm{~d}, 1 \mathrm{H}, J=15.3 \mathrm{~Hz}\right.$, a másik 1- $\left.\mathrm{H}_{2}\right), 3.64(\mathrm{t}$, $1 \mathrm{H}, J=8.4 \mathrm{~Hz}, 17-\mathrm{H}), 7.13$ (t, 2H, $J=8.3 \mathrm{~Hz}, 3^{\prime \prime}-\mathrm{H}$ és 5"-H), 7.43 (s, 1H, 3'-H), 7.47 (m, 2H, 2"-H és 6"-H); ${ }^{13} \mathrm{C}$ NMR $\left(\mathrm{CDCl}_{3}, 125 \mathrm{MHz}\right): \delta 11.0(\mathrm{C}-18), 11.5(\mathrm{C}-19), 20.7\left(\mathrm{CH}_{2}\right)$, $23.4\left(\mathrm{CH}_{2}\right), 27.8(\mathrm{C}-4), 29.0\left(\mathrm{CH}_{2}\right), 30.4\left(\mathrm{CH}_{2}\right), 31.2\left(\mathrm{CH}_{2}\right), 35.1\left(\mathrm{CH}_{2}\right), 35.7(\mathrm{C}-5), 36.0(\mathrm{C}-$ 10), 36.6 (C-16), 42.4 (C-9), 42.8 (C-13), 50.8 (C-14), 53.9 (C-8), 81.8 (C-17), 115.9 (d, 2C, $J=22.9 \mathrm{~Hz}, \mathrm{C}-3^{\prime \prime}$ és C-5"), 117.2 (C-2), 124.5 (d, 2C, $J=8.4 \mathrm{~Hz}, \mathrm{C}-2^{\prime \prime}$ és C-6"), 136.0 (C1"), 137.1 (C-3), 138.9 (C-3'), 161.2 (d, 2C, $\left.J=246.3 \mathrm{~Hz}, \mathrm{C}-4^{\prime \prime}\right)$; ESI-MS 409 [M+H] ${ }^{+}$; $\mathrm{C}_{26} \mathrm{H}_{33} \mathrm{FN}_{2} \mathrm{O}$.

22e: IR $\left(\mathrm{cm}^{-1}\right)$ : 3373, $3233(\mathrm{OH}), 1591(\mathrm{Ph} \mathrm{C}=\mathrm{C}), 1504(\mathrm{Ph} \mathrm{C}=\mathrm{C}), 1386\left(\mathrm{CH}_{3}\right), 1074,1055$ (C-O)

${ }^{1} \mathrm{H} \mathrm{NMR}\left(\mathrm{CDCl}_{3}, 500 \mathrm{MHz}\right): \delta 0.76\left(\mathrm{~s}, 3 \mathrm{H}, 18-\mathrm{CH}_{3}\right), 0.81\left(\mathrm{~s}, 3 \mathrm{H}, 19-\mathrm{CH}_{3}\right), 2.17(\mathrm{~d}, 1 \mathrm{H}, J=$

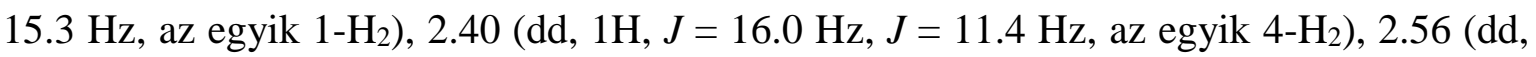
$1 \mathrm{H}, J=16.0 \mathrm{~Hz}, J=3.9 \mathrm{~Hz}$, a másik 4- $\left.\mathrm{H}_{2}\right), 2.63\left(\mathrm{~d}, 1 \mathrm{H}, J=15.3 \mathrm{~Hz}\right.$, a másik 1- $\left.\mathrm{H}_{2}\right), 3.64(\mathrm{t}$, $1 \mathrm{H}, J=8.4 \mathrm{~Hz}, 17-\mathrm{H}), 7.40$ (d, 2H, $J=8.7 \mathrm{~Hz}, 2^{\prime \prime}$ - és 6"-H), 7.44 (s, 1H, 3'-H), 7.47 (d, 2H, $J=8.7 \mathrm{~Hz}, 3$ "-H és 5"-H); ${ }^{13} \mathrm{C}$ NMR $\left(\mathrm{CDCl}_{3}, 125 \mathrm{MHz}\right): \delta 11.0(\mathrm{C}-18), 11.5(\mathrm{C}-19), 20.7$ $\left(\mathrm{CH}_{2}\right), 23.4\left(\mathrm{CH}_{2}\right), 28.0(\mathrm{C}-4), 29.0\left(\mathrm{CH}_{2}\right), 30.4\left(\mathrm{CH}_{2}\right), 31.2\left(\mathrm{CH}_{2}\right), 35.1(\mathrm{C}-1), 35.6(\mathrm{C}-5)$, 35.9 (C-10), 36.6 (C-16), 42.4 (C-9), 42.8 (C-13), 50.8 (C-14), 53.9 (C-8), 81.8 (C-17), 117.6 (C-2), 123.7 (2C, C-2" és C-6"), 129.2 (2C, C-3" és C-5"), 132.1 (C-4"), 137.1 (C-3), 138.4 $\left(\mathrm{C}-1^{\prime \prime}\right), 139.3$ (C-3'); ESI-MS $425[\mathrm{M}+\mathrm{H}]^{+} ; \mathrm{C}_{26} \mathrm{H}_{33} \mathrm{ClN}_{2} \mathrm{O}$.

22f: IR ( $\left.\mathrm{cm}^{-1}\right)$ : 3400, $3371(\mathrm{OH}), 1590(\mathrm{Ph} \mathrm{C}=\mathrm{C}), 1500(\mathrm{Ph} \mathrm{C}=\mathrm{C}), 1384\left(\mathrm{CH}_{3}\right), 1057(\mathrm{C}-\mathrm{O})$. ${ }^{1} \mathrm{H} \mathrm{NMR}\left(\mathrm{CDCl}_{3}, 500 \mathrm{MHz}\right): \delta 0.76\left(\mathrm{~s}, 3 \mathrm{H}, 18-\mathrm{CH}_{3}\right), 0.82\left(\mathrm{~s}, 3 \mathrm{H}, 19-\mathrm{CH}_{3}\right), 2.17(\mathrm{~d}, 1 \mathrm{H}, J=$

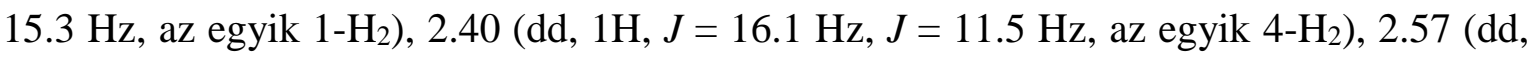

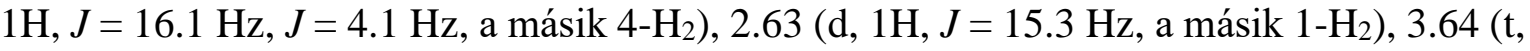
$1 \mathrm{H}, J=8.6 \mathrm{~Hz}, 17-\mathrm{H}), 7.41\left(\mathrm{~d}, 2 \mathrm{H}, J=8.7 \mathrm{~Hz}, 2^{\prime \prime}-\mathrm{H}\right.$ és 6"-H), $7.46\left(\mathrm{~s}, 1 \mathrm{H}, 3{ }^{\prime}-\mathrm{H}\right), 7.56$ (d, $2 \mathrm{H}, J=8.7 \mathrm{~Hz}, 3^{\prime \prime}-\mathrm{H}$ és $\left.5^{\prime \prime}-\mathrm{H}\right) ;{ }^{13} \mathrm{C} \mathrm{NMR}\left(\mathrm{CDCl}_{3}, 125 \mathrm{MHz}\right): \delta 11.0(\mathrm{C}-18), 11.5(\mathrm{C}-19)$, $20.7\left(\mathrm{CH}_{2}\right), 23.4\left(\mathrm{CH}_{2}\right), 28.0(\mathrm{C}-4), 29.0\left(\mathrm{CH}_{2}\right), 30.5\left(\mathrm{CH}_{2}\right), 31.2\left(\mathrm{CH}_{2}\right), 35.1(\mathrm{C}-1), 35.7(\mathrm{C}-$ 5), 35.9 (C-10), 36.6 (C-16), 42.4 (C-9), 42.8 (C-13), 50.8 (C-14), 53.9 (C-8), 81.8 (C-17), 
117.7 (C-2), 120.1 (C-4"), 124.0 (2C, C-2" és C-6"), 132.2 (2C, C-3" és C-5"), 137.2 (C-3), $138.8\left(\mathrm{C}-1^{\prime \prime}\right), 139.2\left(\mathrm{C}-3^{\prime}\right)$; ESI-MS $469[\mathrm{M}+\mathrm{H}]^{+} ; \mathrm{C}_{26} \mathrm{H}_{33} \mathrm{BrN}_{2} \mathrm{O}$.

22g: IR $\left(\mathrm{cm}^{-1}\right)$ : 3538, $2224(\mathrm{C} \equiv \mathrm{N}), 1602(\mathrm{Ph} \mathrm{C}=\mathrm{C}), 1573(\mathrm{C}=\mathrm{N}) 1514(\mathrm{Ph} \mathrm{C}=\mathrm{C}), 1383$ $\left(\mathrm{CH}_{3}\right), 1058,1041(\mathrm{C}-\mathrm{O})$.

${ }^{1} \mathrm{H} \mathrm{NMR}\left(\mathrm{CDCl}_{3}, 500 \mathrm{MHz}\right): \delta 0.78\left(\mathrm{~s}, 3 \mathrm{H}, 18-\mathrm{CH}_{3}\right), 0.83\left(\mathrm{~s}, 3 \mathrm{H}, 19-\mathrm{CH}_{3}\right), 2.19(\mathrm{~d}, 1 \mathrm{H}, J=$ $15.5 \mathrm{~Hz}$, az egyik 1- $\left.\mathrm{H}_{2}\right), 2.49\left(\mathrm{~m}, 1 \mathrm{H}\right.$, az egyik 4- $\left.\mathrm{H}_{2}\right), 2.65\left(\mathrm{~m}, 2 \mathrm{H}\right.$, a másik $1-\mathrm{H}_{2}$ és 4- $\left.\mathrm{H}_{2}\right)$, 3.66 (t, 1H, J = 8.3 Hz, 17-H), 7.51 (s, 1H, 3'-H), 7.72 (m, 4H, 2"-H, 6"-H és 3"-H, 5"-H); ESI-MS $416[\mathrm{M}+\mathrm{H}]^{+} ; \mathrm{C}_{27} \mathrm{H}_{33} \mathrm{~N}_{3} \mathrm{O}$.

22h: IR $\left(\mathrm{cm}^{-1}\right)$ : $3583(\mathrm{OH}), 1610(\mathrm{Ph} \mathrm{C}=\mathrm{C}), 1592(\mathrm{C}=\mathrm{N}), 1504(\mathrm{Ph} \mathrm{C}=\mathrm{C}), 1381\left(\mathrm{CH}_{3}\right), 1075$, 1060 (C-O).

${ }^{1} \mathrm{H} \mathrm{NMR}\left(\mathrm{CDCl}_{3}, 500 \mathrm{MHz}\right): \delta 0.77\left(\mathrm{~s}, 3 \mathrm{H}, 18-\mathrm{CH}_{3}\right), 0.84$ (s, 3H, 19-CH $), 2.19(\mathrm{~d}, 1 \mathrm{H}, J=$ $15.6 \mathrm{~Hz}$, az egyik 1- $\left.\mathrm{H}_{2}\right), 2.52\left(\mathrm{dd}, 1 \mathrm{H}, J=16.2 \mathrm{~Hz}, J=11.5 \mathrm{~Hz}\right.$, az egyik $\left.4-\mathrm{H}_{2}\right), 2.65(\mathrm{~d}, 1 \mathrm{H}$,

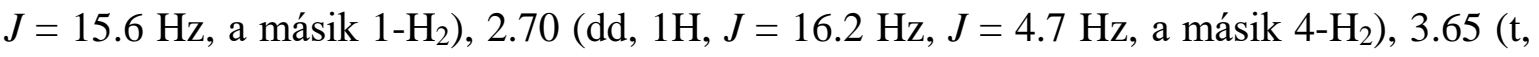
$1 \mathrm{H}, J=8.5 \mathrm{~Hz}, 17-\mathrm{H}), 7.53\left(\mathrm{~s}, 1 \mathrm{H}, 3^{\prime}-\mathrm{H}\right), 7.77$ (d, 2H, $J=9.1 \mathrm{~Hz}, 2^{\prime \prime}-\mathrm{H}$ és 6"-H), 8.32 (d, $2 \mathrm{H}, J=9.1 \mathrm{~Hz}, 3 "-\mathrm{H}$ és $5 "-\mathrm{H}) ;{ }^{13} \mathrm{C} \mathrm{NMR}\left(\mathrm{CDCl}_{3}, 125 \mathrm{MHz}\right): \delta 11.0(\mathrm{C}-18), 11.6(\mathrm{C}-19)$, $20.7\left(\mathrm{CH}_{2}\right), 23.4\left(\mathrm{CH}_{2}\right), 28.8(\mathrm{C}-4), 29.0\left(\mathrm{CH}_{2}\right), 30.5\left(\mathrm{CH}_{2}\right), 31.2\left(\mathrm{CH}_{2}\right), 35.1(\mathrm{C}-1), 35.6(\mathrm{C}-$ 5), 35.8 (C-10), 36.6 (C-16), 42.5 (C-9), 42.8 (C-13), 50.8 (C-14), 53.8 (C-8), 81.8 (C-17), 119.3 (C-2), 121.5 (2C, C-2" és C-6"), 124.9 (2C, C-3" és C-5"), 137.6 (C-3), 141.0 (C-3'), 144.9 és 145,1: C-1" és C-4"; ESI-MS $436[\mathrm{M}+\mathrm{H}]^{+} ; \mathrm{C}_{26} \mathrm{H}_{33} \mathrm{~N}_{3} \mathrm{O}_{3}$.

23a: IR $\left(\mathrm{cm}^{-1}\right)$ : 3481, $3330(\mathrm{OH}), 1598(\mathrm{Ph} \mathrm{C}=\mathrm{C}), 1567(\mathrm{C}=\mathrm{N}), 1498(\mathrm{Ph} \mathrm{C}=\mathrm{C}), 1378\left(\mathrm{CH}_{3}\right)$ 1071, 1047 (C-O).

${ }^{1} \mathrm{H} \mathrm{NMR}\left(\mathrm{CDCl}_{3}, 500 \mathrm{MHz}\right): \delta 0.76\left(\mathrm{~s}, 3 \mathrm{H}, 18-\mathrm{CH}_{3}\right), 0.80\left(\mathrm{~s}, 3 \mathrm{H}, 19-\mathrm{CH}_{3}\right), 2.14(\mathrm{~d}, 1 \mathrm{H}, J=$

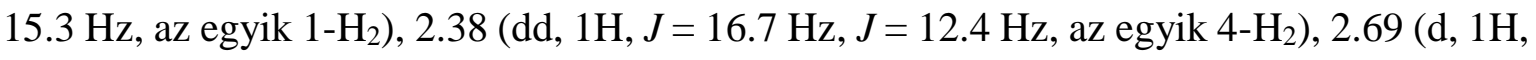

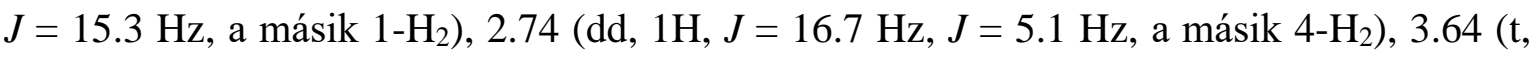
$1 \mathrm{H}, J=8.5 \mathrm{~Hz}, 17-\mathrm{H}$ ), 7.21 (t-szerü m, 1H, 4"-H), 7.40 (t-szerü m, 2H, 3"-H és 5"-H), 7.60 (s, 1H, 5'-H), $7.62\left(\mathrm{~d}, 2 \mathrm{H}, J=8.0 \mathrm{~Hz}, 2^{\prime \prime}-\mathrm{H}\right.$ és $\left.6 "-\mathrm{H}\right) ;{ }^{13} \mathrm{C} \mathrm{NMR}\left(\mathrm{CDCl}_{3}, 125 \mathrm{MHz}\right): \delta 11.0$ (C-18), $11.6(\mathrm{C}-19), 20.8\left(\mathrm{CH}_{2}\right), 23.4\left(\mathrm{CH}_{2}\right), 27.6(\mathrm{C}-4), 29.3\left(\mathrm{CH}_{2}\right), 30.5\left(\mathrm{CH}_{2}\right), 31.3\left(\mathrm{CH}_{2}\right)$, 34.8 (C-1), 35.8 (C-5), 36.3 (C-10), 36.7 (C-16), 42.5 (C-9), 42.8 (C-13), 50.9 (C-14), 53.9 (C-8), 81.9 (C-17), 117.8 (C-2), 118.5 (2C, C-2" és C-6"), 124.3 (C-5'), $125.6\left(\mathrm{C}-4^{\prime \prime}\right), 129.3$ (2C, C-3" és C-5"), 140.2 (C-1"), 150.1 (C-3); ESI-MS $391[\mathrm{M}+\mathrm{H}]^{+} ; \mathrm{C}_{26} \mathrm{H}_{34} \mathrm{~N}_{2} \mathrm{O}$.

23b: IR ( $\left.\mathrm{cm}^{-1}\right)$ : 3492, $3330(\mathrm{OH}), 1613(\mathrm{Ph} \mathrm{C}=\mathrm{C}), 1568(\mathrm{C}=\mathrm{N}), 1518(\mathrm{Ph} \mathrm{C}=\mathrm{C}), 1376\left(\mathrm{CH}_{3}\right)$, 1042, 1026 (C-O)

${ }^{1} \mathrm{H} \mathrm{NMR}\left(\mathrm{CDCl}_{3}, 500 \mathrm{MHz}\right): \delta 0.76\left(\mathrm{~s}, 3 \mathrm{H}, 18-\mathrm{CH}_{3}\right), 0.79$ (s, 3H, 19- $\left.\mathrm{CH}_{3}\right), 2.15(\mathrm{~d}, 1 \mathrm{H}, J=$ $15.2 \mathrm{~Hz}$, az egyik 1-H $), 2.35\left(\mathrm{~s}, 3 \mathrm{H}, 4^{\prime \prime}-\mathrm{CH}_{3}\right), 2.37$ (dd, $1 \mathrm{H}, J=16.2 \mathrm{~Hz}, J=12.2 \mathrm{~Hz}, \mathrm{az}$ egyik 4- $\left.\mathrm{H}_{2}\right), 2.68\left(\mathrm{~d}, 1 \mathrm{H}, J=15.2 \mathrm{~Hz}\right.$, a másik 1- $\left.\mathrm{H}_{2}\right), 2.71(\mathrm{dd}, 1 \mathrm{H}, J=16.2 \mathrm{~Hz}, J=4.6 \mathrm{~Hz}$, a másik 4-H $\mathrm{H}_{2}, 3.64(\mathrm{t}, 1 \mathrm{H}, J=8.3 \mathrm{~Hz}, 17-\mathrm{H}), 7.19\left(\mathrm{~d}, 2 \mathrm{H}, J=7.9 \mathrm{~Hz}, 2^{\prime \prime}-\mathrm{H}\right.$ és 6"-H), 7.50 $\left(\mathrm{d}, 2 \mathrm{H}, J=7.9 \mathrm{~Hz}, 3^{\prime \prime}-\mathrm{H}\right.$ és $\left.5^{\prime \prime}-\mathrm{H}\right), 7.55\left(\mathrm{~s}, 1 \mathrm{H}, 5^{\prime}-\mathrm{H}\right) ;{ }^{13} \mathrm{C} \mathrm{NMR}\left(\mathrm{CDCl}_{3}, 125 \mathrm{MHz}\right): \delta 11.0$ (C-18), $11.6(\mathrm{C}-19), 20.8\left(\mathrm{CH}_{2}\right), 20.8\left(4 "-\mathrm{CH}_{3}\right), 23.4\left(\mathrm{CH}_{2}\right), 27.6(\mathrm{C}-4), 29.3\left(\mathrm{CH}_{2}\right), 30.5$ $\left(\mathrm{CH}_{2}\right), 31.3\left(\mathrm{CH}_{2}\right), 34.8$ (C-1), 35.8 (C-5), 36.3 (C-10), 36.7 (C-16), 42.5 (C-9), 42.8 (C-13), 50.9 (C-14), 53.9 (C-8), 81.9 (C-17), 117.5 (C-2), 118.5 (2C, C-2" és C-6"), 124.2 (C-5'), 
129.8 (2C, C-3" és C-5"), 135.3 (C-4"), 138.0 (C-1"), 149.8 (C-3); ESI-MS 405 [M+H] ${ }^{+}$; $\mathrm{C}_{27} \mathrm{H}_{36} \mathrm{~N}_{2} \mathrm{O}$.

23c: IR (cm $\left.{ }^{-1}\right)$ : 3330, $3231(\mathrm{OH}), 1567(\mathrm{C}=\mathrm{N}), 1518(\mathrm{Ph} \mathrm{C}=\mathrm{C}), 1380\left(\mathrm{CH}_{3}\right), 1046,1029$ (C-O)

${ }^{1} \mathrm{H} \mathrm{NMR}\left(\mathrm{CDCl}_{3}, 500 \mathrm{MHz}\right): \delta 0.76\left(\mathrm{~s}, 3 \mathrm{H}, 18-\mathrm{CH}_{3}\right), 0.79\left(\mathrm{~s}, 3 \mathrm{H}, 19-\mathrm{CH}_{3}\right), 2.15(\mathrm{~d}, 1 \mathrm{H}, J$ $=15.3 \mathrm{~Hz}$, az egyik 1- $\left.\mathrm{H}_{2}\right), 2.37\left(\mathrm{dd}, 1 \mathrm{H}, J=16.4 \mathrm{~Hz}, J=12.3 \mathrm{~Hz}\right.$, az egyik 4- $\left.\mathrm{H}_{2}\right), 2.68(\mathrm{~d}$, $1 \mathrm{H}, J=15.3 \mathrm{~Hz}$, a másik 1- $\left.\mathrm{H}_{2}\right), 2.73\left(\mathrm{dd}, 1 \mathrm{H}, J=16.4 \mathrm{~Hz}, J=4.8 \mathrm{~Hz}\right.$, a másik 4- $\left.\mathrm{H}_{2}\right), 3.64$ (t, $1 \mathrm{H}, J=8.5 \mathrm{~Hz}, 17-\mathrm{H}), 3.81$ (s, 3H, 4"-OMe), 6.92 (d, 2H, $J=9.0 \mathrm{~Hz}, 3 "-\mathrm{H}$ és 5"-H), 7.50 (s, 1H, 5'-H), $7.52\left(\mathrm{~d}, 2 \mathrm{H}, J=9.0 \mathrm{~Hz}, 2^{\prime \prime}-\mathrm{H}\right.$ és $\left.6 "-\mathrm{H}\right) ;{ }^{13} \mathrm{C} \mathrm{NMR}\left(\mathrm{CDCl}_{3}, 125 \mathrm{MHz}\right): \delta 11.0$ (C-18), $11.6(\mathrm{C}-19), 20.8\left(\mathrm{CH}_{2}\right), 23.4\left(\mathrm{CH}_{2}\right), 27.5(\mathrm{C}-4), 29.2\left(\mathrm{CH}_{2}\right), 30.5\left(\mathrm{CH}_{2}\right), 31.3\left(\mathrm{CH}_{2}\right)$, 34.8 (C-1), 35.8 (C-5), 36.3 (C-10), 36.7 (C-16), 42.5 (C-9), 42.8 (C-13), 50.9 (C-14), 53.9 (C-8), 55.5 (4"-OMe), 81.9 (C-17), 114.4 (2C, C-3" és C-5"), 117.3 (C-2), 120.3 (2C, C-2" és C-6"), 124.6 (C-5'), 133.9 (C-1"), 149.8 (C-3), 157.7 (C-4"); ESI-MS $421[\mathrm{M}+\mathrm{H}]^{+}$; $\mathrm{C}_{27} \mathrm{H}_{36} \mathrm{~N}_{2} \mathrm{O}_{2}$.

23d: IR $\left(\mathrm{cm}^{-1}\right)$ : 3385, $3226(\mathrm{OH}), 1610(\mathrm{Ph} \mathrm{C}=\mathrm{C}), 1569(\mathrm{C}=\mathrm{N}), 1515(\mathrm{Ph} \mathrm{C}=\mathrm{C}), 1379\left(\mathrm{CH}_{3}\right)$, 1058, 1044 (C-O).

${ }^{1} \mathrm{H} \mathrm{NMR}\left(\mathrm{CDCl}_{3}, 500 \mathrm{MHz}\right): \delta 0.76\left(\mathrm{~s}, 3 \mathrm{H}, 18-\mathrm{CH}_{3}\right), 0.79\left(\mathrm{~s}, 3 \mathrm{H}, 19-\mathrm{CH}_{3}\right), 2.16(\mathrm{~d}, 1 \mathrm{H}, J=$

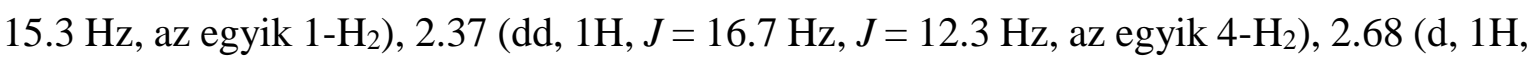

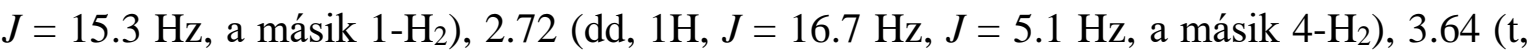
$1 \mathrm{H}, J=8.5 \mathrm{~Hz}, 17-\mathrm{H}), 7.09$ (t, 2H, $J=8.5 \mathrm{~Hz}, 3^{\prime \prime}-\mathrm{H}$ és 5"-H), 7.53 (s, 1H, 5'-H), 7.57 (m, $2 \mathrm{H}, 2^{\prime \prime}-\mathrm{H}$ és $\left.6 "-\mathrm{H}\right) ;{ }^{13} \mathrm{C} \mathrm{NMR}\left(\mathrm{CDCl}_{3}, 125 \mathrm{MHz}\right): \delta 11.0(\mathrm{C}-18), 11.6(\mathrm{C}-19), 20.8\left(\mathrm{CH}_{2}\right)$, $23.4\left(\mathrm{CH}_{2}\right), 27.5(\mathrm{C}-4), 29.2\left(\mathrm{CH}_{2}\right), 30.5\left(\mathrm{CH}_{2}\right), 31.3\left(\mathrm{CH}_{2}\right), 34.7(\mathrm{C}-1), 35.8(\mathrm{C}-5), 36.3(\mathrm{C}-$ 10), 36.7 (C-16), 42.4 (C-9), 42.8 (C-13), 50.9 (C-14), 53.9 (C-8), 55.5 (4"-OMe), 81.9 (C17), 116.0 (d, 2C, $J=22.9$ Hz, C-3" és C-5"), 117.9 (C-2), 120.2 (d, 2C, $J=8.1 \mathrm{~Hz}, \mathrm{C}-2$ " és C-6"), 124.5 (C-5'), 136.5 (C-1"), 150.2 (C-3), 160.6 (d, 2C, $\left.J=245.1 \mathrm{~Hz}, \mathrm{C}-4^{\prime \prime}\right)$; ESI-MS $409[\mathrm{M}+\mathrm{H}]^{+} ; \mathrm{C}_{26} \mathrm{H}_{33} \mathrm{FN}_{2} \mathrm{O}$.

23e: IR ( $\left.\mathrm{cm}^{-1}\right)$ : 3614, $3480(\mathrm{OH}), 1597(\mathrm{Ph} \mathrm{C}=\mathrm{C}), 1569(\mathrm{C}=\mathrm{N}), 1499(\mathrm{Ph} \mathrm{C}=\mathrm{C}), 1375\left(\mathrm{CH}_{3}\right)$, 1040 (C-O).

${ }^{1} \mathrm{H} \mathrm{NMR}\left(\mathrm{CDCl}_{3}, 500 \mathrm{MHz}\right): \delta 0.76\left(\mathrm{~s}, 3 \mathrm{H}, 18-\mathrm{CH}_{3}\right), 0.78\left(\mathrm{~s}, 3 \mathrm{H}, 19-\mathrm{CH}_{3}\right), 2.15(\mathrm{~d}, 1 \mathrm{H}, J=$

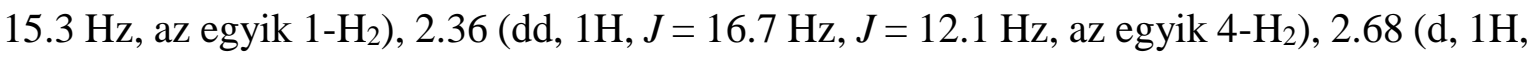

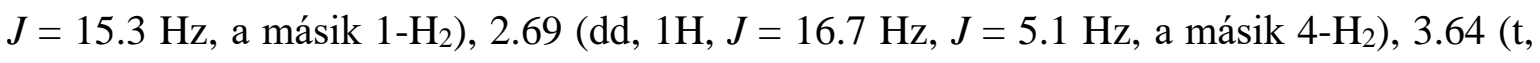
$1 \mathrm{H}, J=8.5 \mathrm{~Hz}, 17-\mathrm{H}), 7.36\left(\mathrm{~d}, 2 \mathrm{H}, J=8.7 \mathrm{~Hz}, 2^{\prime \prime}-\mathrm{H}\right.$ és 6"-H), $7.55\left(\mathrm{~s}, 1 \mathrm{H}, 5{ }^{\prime}-\mathrm{H}\right), 7.56(\mathrm{~d}$, $2 \mathrm{H}, J=8.7 \mathrm{~Hz}, 3 "$-H és $5 "-\mathrm{H}) ;{ }^{13} \mathrm{C} \mathrm{NMR}\left(\mathrm{CDCl}_{3}, 125 \mathrm{MHz}\right): \delta 11.0(\mathrm{C}-18), 11.6(\mathrm{C}-19)$, $20.8\left(\mathrm{CH}_{2}\right), 23.4\left(\mathrm{CH}_{2}\right), 27.5(\mathrm{C}-4), 29.2\left(\mathrm{CH}_{2}\right), 30.5\left(\mathrm{CH}_{2}\right), 31.3\left(\mathrm{CH}_{2}\right), 34.8(\mathrm{C}-1), 35.7(\mathrm{C}-$ 5), 36.3 (C-10), 36.7 (C-16), 42.4 (C-9), 42.8 (C-13), 50.9 (C-14), 53.9 (C-8), 81.9 (C-17), 118.3 (C-2), 119.5 (2C, C-2" és C-6"), 124.1 (C-5'), 129.5 (2C, C-3" és C-5"), 130.8 (C-4"), 138.8 (C-1"), 150.6 (C-3); ESI-MS $425[\mathrm{M}+\mathrm{H}]^{+} ; \mathrm{C}_{26} \mathrm{H}_{33} \mathrm{ClN}_{2} \mathrm{O}$.

23f: IR (cm $\left.{ }^{-1}\right): 3612,3454(\mathrm{OH}), 1592(\mathrm{Ph} \mathrm{C}=\mathrm{C}), 1566(\mathrm{C}=\mathrm{N}), 1495(\mathrm{Ph} \mathrm{C}=\mathrm{C}), 1375\left(\mathrm{CH}_{3}\right)$, 1077, 1041 (C-O)

${ }^{1} \mathrm{H} \mathrm{NMR}\left(\mathrm{CDCl}_{3}, 500 \mathrm{MHz}\right): \delta 0.76\left(\mathrm{~s}, 3 \mathrm{H}, 18-\mathrm{CH}_{3}\right), 0.78\left(\mathrm{~s}, 3 \mathrm{H}, 19-\mathrm{CH}_{3}\right), 2.14(\mathrm{~d}, 1 \mathrm{H}, J=$ $15.3 \mathrm{~Hz}$, az egyik $\left.1-\mathrm{H}_{2}\right), 2.36\left(\mathrm{dd}, 1 \mathrm{H}, J=16.2 \mathrm{~Hz}, J=12.5 \mathrm{~Hz}\right.$, az egyik $\left.4-\mathrm{H}_{2}\right), 2.70(\mathrm{~m}$, 
2H, a másik 4- $\mathrm{H}_{2}$ és 1- $\left.\mathrm{H}_{2}\right), 3.64(\mathrm{t}, 1 \mathrm{H}, J=8.3 \mathrm{~Hz}, 17-\mathrm{H}), 7.50\left(\mathrm{~m}, 4 \mathrm{H}, 2^{\prime \prime}-\mathrm{H}, 3^{\prime \prime}-\mathrm{H}, 5^{\prime \prime}-\mathrm{H}\right.$ és

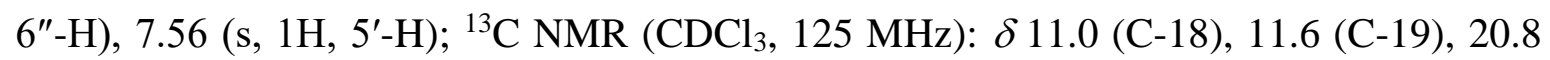
$\left(\mathrm{CH}_{2}\right), 23.4\left(\mathrm{CH}_{2}\right), 27.5(\mathrm{C}-4), 29.2\left(\mathrm{CH}_{2}\right), 30.5\left(\mathrm{CH}_{2}\right), 31.3\left(\mathrm{CH}_{2}\right), 34.8(\mathrm{C}-1), 35.7(\mathrm{C}-5)$, 36.3 (C-10), 36.7 (C-16), 42.4 (C-9), 42.8 (C-13), 50.9 (C-14), 53.8 (C-8), 81.9 (C-17), 118.3 és 118.5: C-2 és C-4", 119.8 (2C, C-2" és C-6"), 124.1 (C-5'), 132.3 (2C, C-3" és C-5"), 139.2 (C-1"), 150,6 (C-3); ESI-MS $469[\mathrm{M}+\mathrm{H}]^{+} ; \mathrm{C}_{26} \mathrm{H}_{33} \mathrm{BrN}_{2} \mathrm{O}$

23g: IR $\left(\mathrm{cm}^{-1}\right)$ : 3509, $3458(\mathrm{OH}), 2222(\mathrm{C} \equiv \mathrm{N}), 1604(\mathrm{Ph} \mathrm{C}=\mathrm{C}), 1586(\mathrm{C}=\mathrm{N}) 1514(\mathrm{Ph} \mathrm{C}=\mathrm{C})$, 1058, $1041(\mathrm{C}-\mathrm{O})$.

${ }^{1} \mathrm{H}$ NMR $\left(\mathrm{CDCl}_{3}, 500 \mathrm{MHz}\right): \delta 0.76\left(\mathrm{~s}, 3 \mathrm{H}, 18-\mathrm{CH}_{3}\right), 0.78\left(\mathrm{~s}, 3 \mathrm{H}, 19-\mathrm{CH}_{3}\right), 2.16(\mathrm{~d}, 1 \mathrm{H}, J=$ $15.4 \mathrm{~Hz}$, az egyik $\left.1-\mathrm{H}_{2}\right), 2.37\left(\mathrm{dd}, 1 \mathrm{H}, J=16.4 \mathrm{~Hz}, J=12.1 \mathrm{~Hz}\right.$, az egyik $\left.4-\mathrm{H}_{2}\right), 2.70(\mathrm{~d}, 1 \mathrm{H}$, $J=15.4 \mathrm{~Hz}$, a másik 1- $\left.\mathrm{H}_{2}\right), 2.72\left(\mathrm{dd}, 1 \mathrm{H}, J=16.4 \mathrm{~Hz}, J=5.3 \mathrm{~Hz}\right.$, a másik 4- $\left.\mathrm{H}_{2}\right), 3.64(\mathrm{t}$, $1 \mathrm{H}, J=8.5 \mathrm{~Hz}, 17-\mathrm{H}), 7.65\left(\mathrm{~s}, 1 \mathrm{H}, 5^{\prime}-\mathrm{H}\right), 7,68\left(\mathrm{~d}, 2 \mathrm{H}, J=8.7 \mathrm{~Hz}, 2^{\prime \prime}-\mathrm{H}\right.$ és 6"-H), $7.73(\mathrm{~d}$, $2 \mathrm{H}, J=8.7 \mathrm{~Hz}, 3^{\prime \prime}-\mathrm{H}$ és $\left.5^{\prime \prime}-\mathrm{H}\right) ;{ }^{13} \mathrm{C} \mathrm{NMR}\left(\mathrm{CDCl}_{3}, 125 \mathrm{MHz}\right): \delta 11.0(\mathrm{C}-18), 11.6(\mathrm{C}-19)$, $20.8\left(\mathrm{CH}_{2}\right), 23.4\left(\mathrm{CH}_{2}\right), 27.5(\mathrm{C}-4), 29.2\left(\mathrm{CH}_{2}\right), 30.5\left(\mathrm{CH}_{2}\right), 31.2\left(\mathrm{CH}_{2}\right), 34.7(\mathrm{C}-1), 35.7(\mathrm{C}-$ 5), 36.2 (C-10), 36.7 (C-16), 42.3 (C-9), 42.8 (C-13), 50.9 (C-14), 53.8 (C-8), 81.8 (C-17), 108.3 (C-4"), 118.0 (2C, C-2" és C-6"), $118.6(\mathrm{C}-2), 119.6(\mathrm{CN}), 124.2\left(\mathrm{C}-5^{\prime}\right), 133.5$ (2C, C-3" és C-5"), 143.0 (C-1"), 152.1 (C-3); ESI-MS $416[\mathrm{M}+\mathrm{H}]^{+} ; \mathrm{C}_{27} \mathrm{H}_{33} \mathrm{~N}_{3} \mathrm{O}$.

23h: IR (cm $\left.{ }^{-1}\right)$ : $3550(\mathrm{OH}), 1595(\mathrm{Ph} \mathrm{C}=\mathrm{C}), 1576(\mathrm{C}=\mathrm{N}), 1507(\mathrm{Ph} \mathrm{C}=\mathrm{C}), 1376\left(\mathrm{CH}_{3}\right), 1080$, 1056 (C-O).

${ }^{1} \mathrm{H} \mathrm{NMR}\left(\mathrm{CDCl}_{3}, 500 \mathrm{MHz}\right): \delta 0.76\left(\mathrm{~s}, 3 \mathrm{H}, 18-\mathrm{CH}_{3}\right), 0.79\left(\mathrm{~s}, 3 \mathrm{H}, 19-\mathrm{CH}_{3}\right), 2.16(\mathrm{~d}, 1 \mathrm{H}, J=$ $15.5 \mathrm{~Hz}$, az egyik $\left.1-\mathrm{H}_{2}\right), 2.37\left(\mathrm{dd}, 1 \mathrm{H}, J=16.6 \mathrm{~Hz}, J=12.4 \mathrm{~Hz}\right.$, az egyik 4- $\left.\mathrm{H}_{2}\right), 2.72(\mathrm{~d}, 1 \mathrm{H}$,

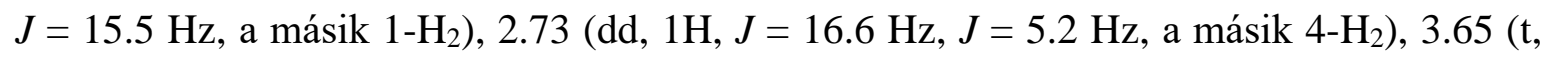
$1 \mathrm{H}, J=8.5 \mathrm{~Hz}, 17-\mathrm{H}), 7.69\left(\mathrm{~s}, 1 \mathrm{H}, 5^{\prime}-\mathrm{H}\right), 7.77\left(\mathrm{~d}, 2 \mathrm{H}, J=7.9 \mathrm{~Hz}, 2^{\prime \prime}-\mathrm{H}\right.$ és 6"-H), $8.28(\mathrm{~d}$, $2 \mathrm{H}, J=7.9 \mathrm{~Hz}, 3 "-\mathrm{H}$ és $5 "-\mathrm{H}) ;{ }^{13} \mathrm{C} \mathrm{NMR}\left(\mathrm{CDCl}_{3}, 125 \mathrm{MHz}\right): \delta 11.0(\mathrm{C}-18), 11.6(\mathrm{C}-19)$, $20.8\left(\mathrm{CH}_{2}\right), 23.4\left(\mathrm{CH}_{2}\right), 27.5(\mathrm{C}-4), 29.2\left(\mathrm{CH}_{2}\right), 30.5\left(\mathrm{CH}_{2}\right), 31.2\left(\mathrm{CH}_{2}\right), 34.7(\mathrm{C}-1), 35.7(\mathrm{C}-$ 5), 36.2 (C-10), 36.7 (C-16), 42.3 (C-9), 42.8 (C-13), 50.9 (C-14), 53.8 (C-8), 81.8 (C-17), 117.5 (2C, C-2" és C-6"), 120.0 (C-2), 124.4 (C-5'), 125.4 (2C, C-3" és C-5"), 144.5 (2C, C-1" és C-4"), 152.6 (C-3); ESI-MS $436[\mathrm{M}+\mathrm{H}]^{+} ; \mathrm{C}_{26} \mathrm{H}_{33} \mathrm{~N}_{3} \mathrm{O}_{3}$.

25a: IR ( $\left.\mathrm{cm}^{-1}\right)$ : 3395, 3254, 1704, 1588, 1542, 1378, 1040, 767, 700, 691

${ }^{1} \mathrm{H} \mathrm{NMR}\left(\mathrm{CDCl}_{3}, 500 \mathrm{MHz}\right): \delta_{\mathrm{H}}=1.04\left(\mathrm{~s}, 3 \mathrm{H}, 18-\mathrm{H}_{3}\right), 1.10\left(\mathrm{~s}, 3 \mathrm{H}, 19-\mathrm{H}_{3}\right), 1.13(\mathrm{~m}, 2 \mathrm{H})$, 1.49-1.91 (átfedő m, 9H), 2.12-2.36 (átfedő m, 4H), 2.53 (t, 1H, $J=13.6 \mathrm{~Hz}$, az egyik 15$\left.\mathrm{H}_{2}\right), 2.80\left(\mathrm{dd}, 1 \mathrm{H}, J=15.0 \mathrm{~Hz}, J=6.3 \mathrm{~Hz}\right.$, a másik 15- $\left.\mathrm{H}_{2}\right), 3.55(\mathrm{~m}, 1 \mathrm{H}, 3-\mathrm{H}), 5.39(\mathrm{~m}, 1 \mathrm{H}$, 6-H), 7.45 (m, 3H, 3"-H, 4"-H és 5"-H), 8.43 (d, 2H, $J=8.3 \mathrm{~Hz}, 2^{\prime \prime}-\mathrm{H}$ és 6"-H), 8.56 (s, $1 \mathrm{H}$, $\left.4^{\prime}-\mathrm{H}\right) ;{ }^{13} \mathrm{C} \mathrm{NMR}\left(\mathrm{CDCl}_{3}, 125 \mathrm{MHz}\right): \delta_{\mathrm{C}}=16.9(\mathrm{C}-19), 19.4(\mathrm{C}-18) 20.5\left(\mathrm{CH}_{2}\right), 28.1(\mathrm{C}-21)$, $30.8(\mathrm{CH}), 31.3\left(\mathrm{CH}_{2}\right), 31.6\left(\mathrm{CH}_{2}\right), 32.8\left(\mathrm{CH}_{2}\right), 36.8(\mathrm{C}-10), 37.1\left(\mathrm{CH}_{2}\right), 42.2\left(\mathrm{CH}_{2}\right), 46.0$ (C-13), $50.6(\mathrm{CH}), 55.8(\mathrm{CH}), 71.6(\mathrm{CH}), 120.8(\mathrm{C}-6), 128.1(2 \mathrm{C})$ és $128.4(2 \mathrm{C})$ : C-2", C-6" és C-3" és C-5"), 130.2 (C-4"), 131.7 (C-1"), 138.0 (C-16), 141.3 (C-5), 151.5 (C-6'), 162.9 (C-2'), 182.2 (C-17); ESI-MS: $401[\mathrm{M}+\mathrm{H}]^{+} ; \mathrm{C}_{27} \mathrm{H}_{32} \mathrm{~N}_{2} \mathrm{O}$.

25b: IR $\left(\mathrm{cm}^{-1}\right)$ : 3440, 3297, 1715, 1587, 1542, 1404, 1382, 1090, 1013, 847, 802 ${ }^{1} \mathrm{H} \mathrm{NMR}\left(\mathrm{CDCl}_{3}, 500 \mathrm{MHz}\right): \delta_{\mathrm{H}}=1.04\left(\mathrm{~s}, 3 \mathrm{H}, 18-\mathrm{H}_{3}\right), 1.10\left(\mathrm{~s}, 3 \mathrm{H}, 19-\mathrm{H}_{3}\right), 1.13(\mathrm{~m}, 2 \mathrm{H})$, 1.49-1.91 (átfedő m, 9H), 2.12-2.33 (átfedő m, 4H), 2.53 (t, 1H, $J=14.2 \mathrm{~Hz}$, az egyik 15- 
$\left.\mathrm{H}_{2}\right), 2.80\left(\mathrm{dd}, 1 \mathrm{H}, J=15.0 \mathrm{~Hz}, J=6.2 \mathrm{~Hz}\right.$, a másik 15- $\left.\mathrm{H}_{2}\right), 3.54(\mathrm{~m}, 1 \mathrm{H}, 3-\mathrm{H}), 5.39(\mathrm{~m}, 1 \mathrm{H}$, 6-H), 7.43 (m, 2H, 3"-H és 5"-H), 8.39 (d, 2H, $J=8.5 \mathrm{~Hz}, 2^{\prime \prime}-\mathrm{H}$ és 6"-H), 8.54 (s, 1H, 4'-H); ${ }^{13} \mathrm{C} \mathrm{NMR}\left(\mathrm{CDCl}_{3}, 125 \mathrm{MHz}\right): \delta \mathrm{C}=16.9(\mathrm{C}-19), 19.4(\mathrm{C}-18) 20.5\left(\mathrm{CH}_{2}\right), 28.1(\mathrm{C}-21), 30.8$ $(\mathrm{CH}), 31.3\left(\mathrm{CH}_{2}\right), 31.6\left(\mathrm{CH}_{2}\right), 32.8\left(\mathrm{CH}_{2}\right), 36.8(\mathrm{C}-10), 37.1\left(\mathrm{CH}_{2}\right), 42.2\left(\mathrm{CH}_{2}\right), 46.1(\mathrm{C}-13)$, $50.6(\mathrm{CH}), 55.8(\mathrm{CH}), 71.6(\mathrm{CH}), 120.8(\mathrm{C}-6), 128.6$ (2C, C-2" és C-6"), 129.5 (2C, C-3" és C-5"), 132.0 (2C, C-16 és C-4"), 136.4 (C-1"), 141.3 (C-5), 151.5 (C-6'), 161.9 (C-2'), 182.3 (C-17). ESI-MS: $436[\mathrm{M}+\mathrm{H}]^{+} ; \mathrm{C}_{27} \mathrm{H}_{31} \mathrm{ClN}_{2} \mathrm{O}$.

26a: IR ( $\left.\mathrm{cm}^{-1}\right)$ : 3375, 1573, 1544, 1422, 1395, 1043, 1026, 747, 693

${ }^{1} \mathrm{H}$ NMR $\left(\mathrm{CDCl}_{3}, 500 \mathrm{MHz}\right): \delta_{\mathrm{H}}=0.79\left(\mathrm{~s}, 3 \mathrm{H}, 18-\mathrm{H}_{3}\right), 0.81\left(\mathrm{~s}, 3 \mathrm{H}, 19-\mathrm{H}_{3}\right), 0.89(\mathrm{~m}, 1 \mathrm{H})$, 0.93-1.04 (átfedő m, 2H), $1.14(\mathrm{~m}, 1 \mathrm{H}), 1.26-1.56$ (átfedő $\mathrm{m}, 5 \mathrm{H}), 1.60-1.73$ (átfedő $\mathrm{m}, 4 \mathrm{H}$ ), $1.78(\mathrm{~m}, 1 \mathrm{H}), 1.90(\mathrm{~m}, 1 \mathrm{H}), 2.07(\mathrm{~m}, 1 \mathrm{H}), 2.41\left(\mathrm{~d}, 1 \mathrm{H}, J=16.2 \mathrm{~Hz}\right.$, az egyik 1- $\left.\mathrm{H}_{2}\right), 2.63(\mathrm{dd}$,

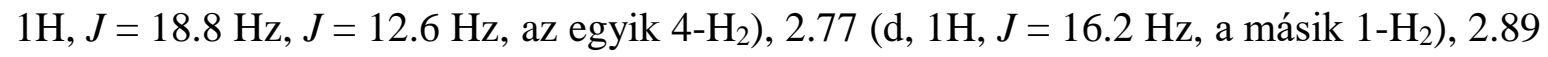
$(\mathrm{dd}, 1 \mathrm{H}, J=18.8 \mathrm{~Hz}, J=5.0 \mathrm{~Hz}$, a másik 4-H $), 3.65(\mathrm{t}, 1 \mathrm{H}, J=8.4 \mathrm{~Hz}, 17-\mathrm{H}), 7.45(\mathrm{~m}, 3 \mathrm{H}$, 3"-H, 4"-H és 5"-H), 8.39 (d, 2H, $J=8.3 \mathrm{~Hz}, 2$ "-H és 6"-H), 8.45 (s, 1H, 6'-H); ${ }^{13} \mathrm{C}$ NMR $\left(\mathrm{CDCl}_{3}, 125 \mathrm{MHz}\right): \delta_{\mathrm{C}}=11.1(\mathrm{C}-18), 11.8(\mathrm{C}-19), 21.1\left(\mathrm{CH}_{2}\right), 23.5\left(\mathrm{CH}_{2}\right), 28.6\left(\mathrm{CH}_{2}\right), 30.8$ $\left.\left(\mathrm{CH}_{2}\right), 31.3\left(\mathrm{CH}_{2}\right), 35.4(\mathrm{C}-10), 35.9(\mathrm{C}-5)\right), 36.4\left(\mathrm{CH}_{2}\right), 37.0\left(\mathrm{CH}_{2}\right), 40.1\left(\mathrm{CH}_{2}\right), 41.9(\mathrm{CH})$, $43.1(\mathrm{C}-13), 51.3(\mathrm{CH}), 54.1(\mathrm{CH}), 82.0$ (C-17), 127.0 (C-2), 127.9 (2C) és 128.5 (2C): C2", C-6" és C-3", C-5", 130.2 (C-4"), 138.0 (C-1"), 157.4 (C-6'), 162.2 (C-2'), 165.5 (C-3); ESI-MS: $403[\mathrm{M}+\mathrm{H}]^{+} ; \mathrm{C}_{27} \mathrm{H}_{34} \mathrm{~N}_{2} \mathrm{O}$.

26b: IR (cm $\left.{ }^{-1}\right)$ : 3477, 1582, 1546, 1438, 1425, 1407, 1375, 1088, 1013, 845, 786 ${ }^{1} \mathrm{H}$ NMR $\left(\mathrm{CDCl}_{3}, 500 \mathrm{MHz}\right): \delta_{\mathrm{H}}=0.76\left(\mathrm{~s}, 3 \mathrm{H}, 18-\mathrm{H}_{3}\right), 0.77\left(\mathrm{~s}, 3 \mathrm{H}, 19-\mathrm{H}_{3}\right), 0.84(\mathrm{~m}, 1 \mathrm{H})$, 0.90-1.00 (átfedő m, 2H), 1.11 (m, 1H), 1.23-1.50 (átfedő m, 5H), 1.59-1.69 (átfedő m, 4H), $1.75(\mathrm{~m}, 1 \mathrm{H}), 1.87(\mathrm{~m}, 1 \mathrm{H}), 2.07(\mathrm{~m}, 1 \mathrm{H}), 2.37\left(\mathrm{~d}, 1 \mathrm{H}, J=16.2 \mathrm{~Hz}\right.$, az egyik 1- $\left.\mathrm{H}_{2}\right), 2.60$ (dd,

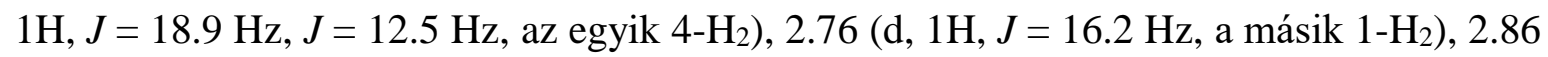
(dd, $1 \mathrm{H}, J=18.9 \mathrm{~Hz}, J=4.5 \mathrm{~Hz}$, a másik 4-H2), $3.65(\mathrm{t}, 1 \mathrm{H}, J=8.4 \mathrm{~Hz}, 17-\mathrm{H}), 7.43(\mathrm{~d}, 2 \mathrm{H}$, $J=8.4 \mathrm{~Hz}, 3^{\prime \prime}-\mathrm{H}$ és $\left.5^{\prime \prime}-\mathrm{H}\right), 8.35$ (d, 2H, $J=8.4 \mathrm{~Hz}, 2^{\prime \prime}-\mathrm{H}$ és $\left.6 "-\mathrm{H}\right), 8.42\left(\mathrm{~s}, 1 \mathrm{H}, 66^{\prime}-\mathrm{H}\right)$; ${ }^{13} \mathrm{C}$ $\mathrm{NMR}\left(\mathrm{CDCl}_{3}, 125 \mathrm{MHz}\right): \delta_{\mathrm{C}}=11.1(\mathrm{C}-18), 11.7(\mathrm{C}-19), 20.9\left(\mathrm{CH}_{2}\right), 23.3\left(\mathrm{CH}_{2}\right), 28.3\left(\mathrm{CH}_{2}\right)$, $30.5\left(\mathrm{CH}_{2}\right), 31.0\left(\mathrm{CH}_{2}\right), 35.1(\mathrm{C}-10), 35.5(\mathrm{C}-5), 36.2\left(\mathrm{CH}_{2}\right), 36.6\left(\mathrm{CH}_{2}\right), 39.7\left(\mathrm{CH}_{2}\right), 41.4$ $(\mathrm{CH}), 42.8(\mathrm{C}-13), 50.8(\mathrm{CH}), 53.6(\mathrm{CH}), 81.8(\mathrm{C}-17), 127.4(\mathrm{C}-2), 128.7$ (2C, C-2" és C6"), 129.3 (2C, C-3" és C-5"), 136.1 (C-4"), 136.4 (C-1"), 157.3 (C-6'), 160.8 (C-2'), 165.7 (C-3); ESI-MS: $437[\mathrm{M}+\mathrm{H}]^{+} ; \mathrm{C}_{27} \mathrm{H}_{33} \mathrm{ClN}_{2} \mathrm{O}$.

26c: IR $\left(\mathrm{cm}^{-1}\right)$ : 3474, 1579, 1569, 1545, 1436, 1426, 1406, 1386, 1078, 1066, 1027, 1010, $844,784,752$

${ }^{1} \mathrm{H}$ NMR $\left(\mathrm{CDCl}_{3}, 500 \mathrm{MHz}\right): \delta_{\mathrm{H}}=0.77\left(2 \times \mathrm{s}, 2 \times 3 \mathrm{H}, 18-\mathrm{H}_{3}\right.$ és 19- $\left.\mathrm{H}_{3}\right), 0.84(\mathrm{~m}, 1 \mathrm{H}), 0.90-$ 1.00 (átfedő m, 2H), 1.11 (m, 1H), 1.24-1.51 (átfedő m, 5H), 1.59-1.69 (átfedő m, 4H), 1.75 $(\mathrm{m}, 1 \mathrm{H}), 1.87(\mathrm{~m}, 1 \mathrm{H}), 2.07(\mathrm{~m}, 1 \mathrm{H}), 2.36\left(\mathrm{~d}, 1 \mathrm{H}, J=16.3 \mathrm{~Hz}\right.$, az egyik 1- $\left.\mathrm{H}_{2}\right), 2.59$ (dd, 1H,

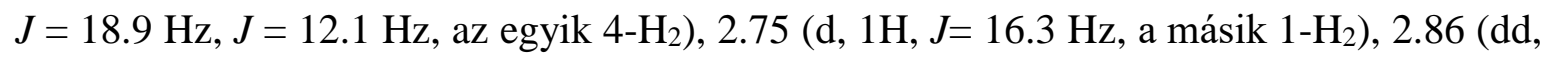
$1 \mathrm{H}, J=18.9 \mathrm{~Hz}, J=5.0 \mathrm{~Hz}$, a másik 4- $\left.\mathrm{H}_{2}\right), 3.66(\mathrm{t}, 1 \mathrm{H}, J=8.4 \mathrm{~Hz}, 17-\mathrm{H}), 7.58(\mathrm{~d}, 2 \mathrm{H}, J=$ $8.4 \mathrm{~Hz}, 2^{\prime \prime}-\mathrm{H}$ és 6"-H), 8.28 (d, 2H, $J=8.4 \mathrm{~Hz}, 3$ "-H és 5"-H), 8.41 (s, $\left.1 \mathrm{H}, 66^{\prime}-\mathrm{H}\right)$; ${ }^{13} \mathrm{C}$ NMR $\left(\mathrm{CDCl}_{3}, 125 \mathrm{MHz}\right): \delta_{\mathrm{C}}=11.1(\mathrm{C}-18), 11.7(\mathrm{C}-19), 20.9\left(\mathrm{CH}_{2}\right), 23.4\left(\mathrm{CH}_{2}\right), 28.4\left(\mathrm{CH}_{2}\right), 30.5$ $\left(\mathrm{CH}_{2}\right), 31.0\left(\mathrm{CH}_{2}\right), 35.1(\mathrm{C}-10), 35.5(\mathrm{C}-5), 36.2\left(\mathrm{CH}_{2}\right), 36.6\left(\mathrm{CH}_{2}\right), 39.8\left(\mathrm{CH}_{2}\right), 41.4(\mathrm{CH})$, 
42.8 (C-13), $50.9(\mathrm{CH}), 53.6(\mathrm{CH}), 81.8$ (C-17), 124.9 (C-4"), 127.4 (C-2), 129.5 (2C, C-2" és C-6"), 131.6 (2C, C-3" és C-5"), 136.7 (C-1"), 157.4 (C-6'), 160.9 (C-2'), 165.6 (C-3); ESI-MS: $481[\mathrm{M}+\mathrm{H}]^{+} ; \mathrm{C}_{27} \mathrm{H}_{33} \mathrm{BrN}_{2} \mathrm{O}$.

26d: IR (cm $\left.{ }^{-1}\right)$ : 3377, 1601, 1577, 1545, 1511, 1439, 1426, 1414, 1389, 1218, 1148, 1082, $1057,1045,1027,1013,851,790$

${ }^{1} \mathrm{H} \mathrm{NMR}\left(\mathrm{CDCl}_{3}, 500 \mathrm{MHz}\right): \delta_{\mathrm{H}}=0.76\left(\mathrm{~s}, 3 \mathrm{H}, 18-\mathrm{H}_{3}\right), 0.77\left(\mathrm{~s}, 3 \mathrm{H}, 19-\mathrm{H}_{3}\right), 0.84(\mathrm{~m}, 1 \mathrm{H})$, 0.90-1.00 (átfedő m, 2H), 1.11 (m, 1H), 1.23-1.50 (átfedő m, 5H), 1.60-1.69 (átfedő m, 4H), $1.75(\mathrm{~m}, 1 \mathrm{H}), 1.86(\mathrm{~m}, 1 \mathrm{H}), 2.06(\mathrm{~m}, 1 \mathrm{H}), 2.37\left(\mathrm{~d}, 1 \mathrm{H}, J=16.2 \mathrm{~Hz}\right.$, az egyik $\left.1-\mathrm{H}_{2}\right), 2.59(\mathrm{dd}$, $1 \mathrm{H}, J=18.8 \mathrm{~Hz}, J=12.4 \mathrm{~Hz}$, az egyik $\left.4-\mathrm{H}_{2}\right), 2.75\left(\mathrm{~d}, 1 \mathrm{H}, J=16.2 \mathrm{~Hz}\right.$, a másik 1- $\left.\mathrm{H}_{2}\right), 2.86$ $(\mathrm{dd}, 1 \mathrm{H}, J=18.8 \mathrm{~Hz}, J=4.4 \mathrm{~Hz}$, a másik 4-H2), 3.65 (t, $1 \mathrm{H}, J=8.5 \mathrm{~Hz}, 17-\mathrm{H}), 7.12(\mathrm{t}, 2 \mathrm{H}$, $J=8.4 \mathrm{~Hz}, 3^{\prime \prime}$-H és $\left.5^{\prime \prime}-\mathrm{H}\right), 8.38$ (m, 2H, 2"-H és 6"-H), 8.40 (s, $\left.1 \mathrm{H}, 66^{\prime}-\mathrm{H}\right) ;{ }^{13} \mathrm{C} \mathrm{NMR}\left(\mathrm{CDCl}_{3}\right.$, $125 \mathrm{MHz}): \delta_{\mathrm{C}}=11.0(\mathrm{C}-18), 11.7(\mathrm{C}-19), 20.9\left(\mathrm{CH}_{2}\right), 23.3\left(\mathrm{CH}_{2}\right), 28.3\left(\mathrm{CH}_{2}\right), 30.4\left(\mathrm{CH}_{2}\right)$, $31.0\left(\mathrm{CH}_{2}\right), 35.1(\mathrm{C}-10), 35.5(\mathrm{C}-5), 36.2\left(\mathrm{CH}_{2}\right), 36.6\left(\mathrm{CH}_{2}\right), 39.7\left(\mathrm{CH}_{2}\right), 41.4(\mathrm{CH}), 42.8$ (C-13), $50.8(\mathrm{CH}), 53.6(\mathrm{CH}), 81.8(\mathrm{C}-17), 115.4(\mathrm{~d}, 2 \mathrm{C}, J=21.6 \mathrm{~Hz}, \mathrm{C}-2 "$ és C-6"), 127.0 (C-2), 130.0 (d, 2C, J = 8.5 Hz, C-3" és C-5"), 133.9 (C-1"), 157.4 (C-6'), 161.0 (C-2'), 164.3 (d, $\left.J=249.6 \mathrm{~Hz}, \mathrm{C}-4^{\prime \prime}\right), 165.5$ (C-3); ESI-MS: $421[\mathrm{M}+\mathrm{H}]^{+} ; \mathrm{C}_{27} \mathrm{H}_{33} \mathrm{FN}_{2} \mathrm{O}$.

26e: IR $\left(\mathrm{cm}^{-1}\right)$ : 3354, 1598, 1572, 1549, 1511, 1440, 1414, 1385, 1350, 1084, 1059, 1045, $1014,874,854,743$

${ }^{1} \mathrm{H}$ NMR $\left(\mathrm{CDCl}_{3}, 500 \mathrm{MHz}\right): \delta_{\mathrm{H}}=0.78(\mathrm{~s}, 3 \mathrm{H})$ és $0.82(\mathrm{~s}, 3 \mathrm{H}): 18-\mathrm{H}_{3}$ és 19- $\mathrm{H}_{3}, 0.90(\mathrm{~m}$, $1 \mathrm{H}$ ), 0.95-1.04 (átfedő $\mathrm{m}, 2 \mathrm{H}), 1.14(\mathrm{~m}, 1 \mathrm{H}), 1.25-1.53$ (átfedő $\mathrm{m}, 5 \mathrm{H}), 1.61-1.72$ (átfedő $\mathrm{m}$, 4H), $1.78(\mathrm{~m}, 1 \mathrm{H}), 1.89(\mathrm{~m}, 1 \mathrm{H}), 2.09(\mathrm{~m}, 1 \mathrm{H}), 2.44\left(\mathrm{~d}, 1 \mathrm{H}, J=16.4 \mathrm{~Hz}\right.$, az egyik 1- $\left.\mathrm{H}_{2}\right)$, $2.64(\mathrm{dd}, 1 \mathrm{H}, J=18.9 \mathrm{~Hz}, J=12.6 \mathrm{~Hz}$, az egyik 4-H2), $2.82(\mathrm{~d}, 1 \mathrm{H}, J=16.4 \mathrm{~Hz}$, a másik 1$\left.\mathrm{H}_{2}\right), 2.91\left(\mathrm{dd}, 1 \mathrm{H}, J=18.9 \mathrm{~Hz}, J=5.1 \mathrm{~Hz}\right.$, a másik 4-H $\mathrm{H}_{2}, 3.67(\mathrm{t}, 1 \mathrm{H}, J=8.6 \mathrm{~Hz}, 17-\mathrm{H})$, $8.30\left(\mathrm{~d}, 2 \mathrm{H}, J=8.4 \mathrm{~Hz}, 2^{\prime \prime}-\mathrm{H}\right.$ és $\left.6^{\prime \prime}-\mathrm{H}\right), 8.49\left(\mathrm{~s}, 1 \mathrm{H}, 6^{\prime}-\mathrm{H}\right), 8.59\left(\mathrm{~d}, 2 \mathrm{H}, J=8.4 \mathrm{~Hz}, 3^{\prime \prime}-\mathrm{H}\right.$ és 5"-H); ESI-MS: $448[\mathrm{M}+\mathrm{H}]^{+}$; Anal. Calcd for $\mathrm{C}_{27} \mathrm{H}_{33} \mathrm{~N}_{3} \mathrm{O}_{3}$.

26f: IR $\left(\mathrm{cm}^{-1}\right)$ : 3393, 1607, 1585, 1573, 1543, 1514, 1437, 1417, 1395, 1247, 1164, 1105, 1080, 1028, 842, 789

${ }^{1} \mathrm{H} \mathrm{NMR}\left(\mathrm{CDCl}_{3}, 500 \mathrm{MHz}\right): \delta_{\mathrm{H}}=0.76\left(\mathrm{~s}, 3 \mathrm{H}, 18-\mathrm{H}_{3}\right), 0.77\left(\mathrm{~s}, 3 \mathrm{H}, 19-\mathrm{H}_{3}\right), 0.84(\mathrm{~m}, 1 \mathrm{H})$, 0.90-1.00 (átfedő m, $2 \mathrm{H}$ ), $1.10(\mathrm{~m}, 1 \mathrm{H}), 1.23$-1.50 (átfedő $\mathrm{m}, 5 \mathrm{H}$ ), 1.60-1.70 (átfedő $\mathrm{m}, 4 \mathrm{H}$ ), $1.75(\mathrm{~m}, 1 \mathrm{H}), 1.86(\mathrm{~m}, 1 \mathrm{H}), 2.07(\mathrm{~m}, 1 \mathrm{H}), 2.36\left(\mathrm{~d}, 1 \mathrm{H}, J=16.1 \mathrm{~Hz}\right.$, az egyik 1- $\left.\mathrm{H}_{2}\right), 2.59$ (dd, $1 \mathrm{H}, J=18.7 \mathrm{~Hz}, J=12.5 \mathrm{~Hz}$, az egyik $\left.4-\mathrm{H}_{2}\right), 2.73\left(\mathrm{~d}, 1 \mathrm{H}, J=16.1 \mathrm{~Hz}\right.$, a másik $\left.1-\mathrm{H}_{2}\right), 2.85$ $(\mathrm{dd}, 1 \mathrm{H}, J=18.7 \mathrm{~Hz}, J=4.6 \mathrm{~Hz}$, a másik 4-H2), $3.65(\mathrm{t}, 1 \mathrm{H}, J=8.3 \mathrm{~Hz}, 17-\mathrm{H}), 3.86(\mathrm{~s}, 3 \mathrm{H}$, 4"-OMe), 6.97 (d, 2H, $J=8.3 \mathrm{~Hz}, 3^{\prime \prime}-\mathrm{H}$ és 5"-H), 8.34 (d, 2H, $J=8.3 \mathrm{~Hz}, 2^{\prime \prime}-\mathrm{H}$ és 6"-H), 8.39 (s, 1H, 6'-H); ${ }^{13} \mathrm{C} \mathrm{NMR}\left(\mathrm{CDCl}_{3}, 125 \mathrm{MHz}\right): \delta \mathrm{C}=11.0(\mathrm{C}-18), 11.7(\mathrm{C}-19), 20.9\left(\mathrm{CH}_{2}\right)$, $23.3\left(\mathrm{CH}_{2}\right), 28.4\left(\mathrm{CH}_{2}\right), 30.5\left(\mathrm{CH}_{2}\right), 31.0\left(\mathrm{CH}_{2}\right), 35.1(\mathrm{C}-10), 35.5(\mathrm{C}-5), 36.2\left(\mathrm{CH}_{2}\right), 36.6$ $\left(\mathrm{CH}_{2}\right), 39.7\left(\mathrm{CH}_{2}\right), 41.5(\mathrm{CH}), 42.8(\mathrm{C}-13), 50.8(\mathrm{CH}), 53.6(\mathrm{CH}), 55.3\left(4^{\prime \prime}-\mathrm{OMe}\right), 81.8(\mathrm{C}-$ 17), 113.8 (2C, C-3" és C-5"), 126.2 (C-2), 129.4 (2C, C-2" és C-6"), 130.4 (C-1"), 157.3 (C-6'), 161.4 (C-4"), 161.7 (C-2'), 165.3 (C-3); ESI-MS: 433 [M+H] $]^{+} ; \mathrm{C}_{28} \mathrm{H}_{36} \mathrm{~N}_{2} \mathrm{O}_{2}$.

26g: IR ( $\left.\mathrm{cm}^{-1}\right)$ : 3384, 1610, 1571, 1541, 1434, 1423, 1082, 1028, 1018, 838, 783 ${ }^{1} \mathrm{H} \mathrm{NMR}\left(\mathrm{CDCl}_{3}, 500 \mathrm{MHz}\right): \delta_{\mathrm{H}}=0.79\left(\mathrm{~s}, 3 \mathrm{H}, 18-\mathrm{H}_{3}\right), 0.80\left(\mathrm{~s}, 3 \mathrm{H}, 19-\mathrm{H}_{3}\right), 0.88(\mathrm{~m}, 1 \mathrm{H})$, 0.92-1.03 (átfedő m, 2H), 1.13 (m, 1H), 1.26-1.54 (átfedő m, 5H), 1.60-1.72 (átfedő m, 4H), 
$1.78(\mathrm{~m}, 1 \mathrm{H}), 1.90(\mathrm{~m}, 1 \mathrm{H}), 2.07(\mathrm{~m}, 1 \mathrm{H}), 2.38\left(\mathrm{~d}, 1 \mathrm{H}, J=16.2 \mathrm{~Hz}\right.$, az egyik 1- $\left.\mathrm{H}_{2}\right), 2.40(\mathrm{~s}$, $\left.3 \mathrm{H}, 4^{\prime \prime}-\mathrm{CH}_{3}\right), 2.61\left(\mathrm{dd}, 1 \mathrm{H}, J=18.9 \mathrm{~Hz}, J=12.3 \mathrm{~Hz}\right.$, az egyik 4-H $\mathrm{H}_{2}, 2.75(\mathrm{~d}, 1 \mathrm{H}, J=16.2$ $\mathrm{Hz}$, other of 1- $\left.\mathrm{H}_{2}\right), 2.87\left(\mathrm{dd}, 1 \mathrm{H}, J=18.9 \mathrm{~Hz}, J=5.0 \mathrm{~Hz}\right.$, other of $\left.4-\mathrm{H}_{2}\right), 3.66(\mathrm{t}, 1 \mathrm{H}, J=8.4$ $\mathrm{Hz}, 17-\mathrm{H}), 7.26\left(\mathrm{~d}, 2 \mathrm{H}, J=7.7 \mathrm{~Hz}, 3^{\prime \prime}-\mathrm{H}\right.$ és 5"-H), $8.32\left(\mathrm{~d}, 2 \mathrm{H}, J=7.7 \mathrm{~Hz}, 2^{\prime \prime}-\mathrm{H}\right.$ és 6"-H), $8.41\left(\mathrm{~s}, 1 \mathrm{H}, 6^{\prime}-\mathrm{H}\right) ;{ }^{13} \mathrm{C} \mathrm{NMR}\left(\mathrm{CDCl}_{3}, 125 \mathrm{MHz}\right): \delta_{\mathrm{C}}=11.1(\mathrm{C}-18), 11.8(\mathrm{C}-19), 21.1\left(\mathrm{CH}_{2}\right)$, $21.3\left(4 "-\mathrm{CH}_{3}\right), 23.5\left(\mathrm{CH}_{2}\right), 28.6\left(\mathrm{CH}_{2}\right), 30.8\left(\mathrm{CH}_{2}\right), 31.3\left(\mathrm{CH}_{2}\right), 35.4(\mathrm{C}-10), 35.9(\mathrm{C}-5), 36.5$ $\left(\mathrm{CH}_{2}\right), 37.0\left(\mathrm{CH}_{2}\right), 40.1\left(\mathrm{CH}_{2}\right), 41.9(\mathrm{CH}), 43.1(\mathrm{C}-13), 51.3(\mathrm{CH}), 54.1(\mathrm{CH}), 82.0(\mathrm{C}-17)$, 126.6 (C-2), 128.1 (2C) és 129.2 (2C): C-2", C-6" és C-3", C-5", 135.4 (C-1"), 140.3 (C-4"), $157.4\left(\mathrm{C}-6^{\prime}\right), 162.3\left(\mathrm{C}-2^{\prime}\right), 165.4(\mathrm{C}-3)$; ESI-MS: $417[\mathrm{M}+\mathrm{H}]^{+} ; \mathrm{C}_{28} \mathrm{H}_{36} \mathrm{~N}_{2} \mathrm{O}$.

26h: IR (cm $\left.{ }^{-1}\right): 3470,1575,1543,1425,1398,1383,1255,1115,1081,1061,1043,1007$, 771,696

${ }^{1} \mathrm{H} \mathrm{NMR}\left(\mathrm{CDCl}_{3}, 500 \mathrm{MHz}\right): \delta_{\mathrm{H}}=0.77\left(\mathrm{~s}, 3 \mathrm{H}, 18-\mathrm{H}_{3}\right), 0.78\left(\mathrm{~s}, 3 \mathrm{H}, 19-\mathrm{H}_{3}\right), 0.85(\mathrm{~m}, 1 \mathrm{H})$, 0.89-1.00 (átfedő m, 2H), 1.10 (m, 1H), 1.23-1.50 (átfedő m, 5H), 1.59-1.70 (átfedő m, 4H), $1.75(\mathrm{~m}, 1 \mathrm{H}), 1.87(\mathrm{~m}, 1 \mathrm{H}), 2.06(\mathrm{~m}, 1 \mathrm{H}), 2.37\left(\mathrm{~d}, 1 \mathrm{H}, J=16.3 \mathrm{~Hz}\right.$, az egyik 1- $\left.\mathrm{H}_{2}\right), 2.43(\mathrm{~s}$, $\left.3 \mathrm{H}, 3^{\prime \prime}-\mathrm{CH}_{3}\right), 2.61(\mathrm{dd}, 1 \mathrm{H}, J=18.8 \mathrm{~Hz}, J=12.5 \mathrm{~Hz}$, az egyik 4-H $), 2.76(\mathrm{~d}, 1 \mathrm{H}, J=16.3$

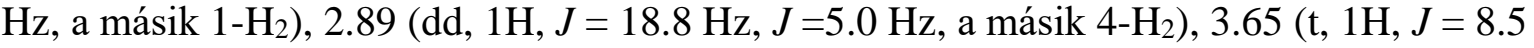
$\mathrm{Hz}, 17-\mathrm{H}), 7.26$ (d, 2H, $\left.J=7.6 \mathrm{~Hz}, 4^{\prime \prime}-\mathrm{H}\right), 7.35$ (t, 1H, $\left.J=7.6 \mathrm{~Hz}, 5^{\prime \prime}-\mathrm{H}\right), 8.18$ (d, 1H, $J=$ $7.6 \mathrm{~Hz}, 6 "-\mathrm{H}), 8.19\left(\mathrm{~s}, 1 \mathrm{H}, 2^{\prime \prime}-\mathrm{H}\right), 8.44\left(\mathrm{~s}, 1 \mathrm{H}, 66^{\prime}-\mathrm{H}\right) ;{ }^{13} \mathrm{C} \mathrm{NMR}\left(\mathrm{CDCl}_{3}, 125 \mathrm{MHz}\right): \delta_{\mathrm{C}}=$ 11.0 (C-18), 11.7 (C-19), $20.9\left(\mathrm{CH}_{2}\right), 21.5\left(3 "-\mathrm{CH}_{3}\right), 23.3\left(\mathrm{CH}_{2}\right), 28.3\left(\mathrm{CH}_{2}\right), 30.5\left(\mathrm{CH}_{2}\right)$, $31.0\left(\mathrm{CH}_{2}\right), 35.1(\mathrm{C}-10), 35.5(\mathrm{C}-5), 36.2\left(\mathrm{CH}_{2}\right), 36.6\left(\mathrm{CH}_{2}\right), 39.7\left(\mathrm{CH}_{2}\right), 41.4(\mathrm{CH}), 42.8$ $(\mathrm{C}-13), 50.8(\mathrm{CH}), 53.6(\mathrm{CH}), 81.8(\mathrm{C}-17), 125.1(\mathrm{C}-6 "), 127.0(\mathrm{C}-2), 128.4(2 \mathrm{C}, \mathrm{C}-2 "$ és C5"), 131.0 (C-4"), 137.5 és 138.1: C-1" és C-3", 157.3 (C-6'), 162.0 (C-2'), 165.5 (C-3); ESIMS: $417[\mathrm{M}+\mathrm{H}]^{+} ; \mathrm{C}_{28} \mathrm{H}_{36} \mathrm{~N}_{2} \mathrm{O}$.

26i: IR $\left(\mathrm{cm}^{-1}\right)$ : $3384,1713,1667,1575,1543,1433,1420,1040,1025,939,750$

${ }^{1} \mathrm{H} \mathrm{NMR}\left(\mathrm{CDCl}_{3}, 500 \mathrm{MHz}\right): \delta_{\mathrm{H}}=0.77\left(\mathrm{~s}, 3 \mathrm{H}, 18-\mathrm{H}_{3}\right), 0.81\left(\mathrm{~s}, 3 \mathrm{H}, 19-\mathrm{H}_{3}\right), 2.42(\mathrm{~d}, 1 \mathrm{H}, J=$ $16.3 \mathrm{~Hz}$, az egyik 1-H2), $2.49\left(\mathrm{~s}, 3 \mathrm{H}, 2^{\prime \prime}-\mathrm{CH}_{3}\right), 2.61(\mathrm{dd}, 1 \mathrm{H}, J=18.9 \mathrm{~Hz}, J=12.5 \mathrm{~Hz}$, az

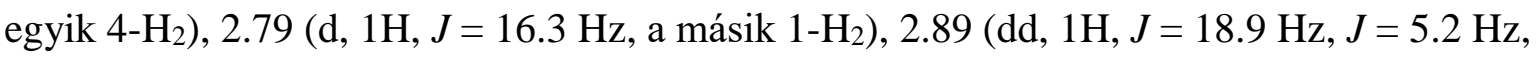
a másik 4- $\mathrm{H}_{2}$ ), 3.65 (t, 1H, $J=8.5 \mathrm{~Hz}, 17-\mathrm{H}$ ), 7.25-7.31 (átfedő m, 3H, 3"-H, 4"-H, 5"-H), $7.69\left(\mathrm{~d}, 1 \mathrm{H}, J=7.44 \mathrm{~Hz}, 6^{\prime \prime}-\mathrm{H}\right), 8.47$ (s, 1H, 6'-H); ESI-MS: $417[\mathrm{M}+\mathrm{H}]^{+} ; \mathrm{C}_{28} \mathrm{H}_{36} \mathrm{~N}_{2} \mathrm{O}$.

28a: IR $\left(\mathrm{cm}^{-1}\right)$ : 1732, 1640, 1612, 1545, 1450, 1419, 1238, 793, 775, 703

${ }^{1} \mathrm{H} \mathrm{NMR}\left(\mathrm{CDCl}_{3}, 500 \mathrm{MHz}\right): \delta_{\mathrm{H}}=0.66\left(\mathrm{~s}, 3 \mathrm{H}, 19-\mathrm{H}_{3}\right), 0.73\left(\mathrm{~s}, 3 \mathrm{H}, 18-\mathrm{H}_{3}\right), 0.79-0.96$ (átfedő $\mathrm{m}, 2 \mathrm{H}), 1.02(\mathrm{~m}, 1 \mathrm{H}), 1.13(\mathrm{~m}, 1 \mathrm{H}), 1.24-1.39$ (átfedő $\mathrm{m}, 5 \mathrm{H}), 1.48(\mathrm{~m}, 1 \mathrm{H}), 1.58-1.73$ (átfedő m, 5H), $2.01\left(\mathrm{~s}, 3 \mathrm{H}, \mathrm{Ac}_{-} \mathrm{CH}_{3}\right), 2.14(\mathrm{~m}, 1 \mathrm{H}), 2.23(\mathrm{~d}, 1 \mathrm{H}, J=15.7 \mathrm{~Hz}$, az egyik 1$\left.\mathrm{H}_{2}\right), 2.47(\mathrm{~d}, 1 \mathrm{H}, J=15.7 \mathrm{~Hz}$, a másik 1-H 2$), 2.51(\mathrm{dd}, 1 \mathrm{H}, J=19.3 \mathrm{~Hz}, J=12.4 \mathrm{~Hz}$, az egyik 4-H $\left.\mathrm{H}_{2}\right), 2.87(\mathrm{dd}, 1 \mathrm{H}, J=19.3 \mathrm{~Hz}, J=4.7 \mathrm{~Hz}$, a másik 4-H2), 4.57 (t, $1 \mathrm{H}, J=8.4 \mathrm{~Hz}, 17-\mathrm{H})$, 7.44 (m, 3H, 3"-H, 4"-H és 5"-H), 7.57 (d, 2H, J= 7.4 Hz, 2"-H és 6"-H); ${ }^{13} \mathrm{C} \mathrm{NMR}\left(\mathrm{CDCl}_{3}\right.$, $125 \mathrm{MHz}): \delta 11.3(\mathrm{C}-19), 11.9(\mathrm{C}-18), 20.6\left(\mathrm{CH}_{2}\right), 21.1\left(\mathrm{Ac}-\mathrm{CH}_{3}\right), 23.4\left(\mathrm{CH}_{2}\right), 27.4\left(\mathrm{CH}_{2}\right)$, $27.8\left(\mathrm{CH}_{2}\right), 30.8\left(\mathrm{CH}_{2}\right), 32.0(\mathrm{C}-4), 35.1(\mathrm{C}-8), 35.6(\mathrm{C}-10), 36.7(\mathrm{C}-16), 39.3(\mathrm{C}-1), 40.2$ (C-5), 42.3 (C-13), 50.5 (C-14), 53.3 (C-9), 82.6 (C-17), 111.1 (C-2), 128.1 (2C) és 128.8 (2C): C-2", C-6" és C-3" és C-5", 130.1 (C-4"), 136.2 (C-1"), 158.1 (C-3), 171.1 (Ac-CO) - 
a C-2' és C-4' jelek a tautoméria miatt nem láthatóak a spektrumon; ESI-MS: $461[\mathrm{M}+\mathrm{H}]^{+}$; $\mathrm{C}_{29} \mathrm{H}_{36} \mathrm{~N}_{2} \mathrm{O}_{3}$.

28b: IR $\left(\mathrm{cm}^{-1}\right)$ : 1732, 1640, 1612, 14903, 1433, 1238, 1101, 1090, 835, 790, 723

${ }^{1} \mathrm{H} \mathrm{NMR}\left(\mathrm{CDCl}_{3}, 500 \mathrm{MHz}\right): \delta_{\mathrm{H}}=0.66\left(\mathrm{~s}, 3 \mathrm{H}, 19-\mathrm{H}_{3}\right), 0.74\left(\mathrm{~s}, 3 \mathrm{H}, 18-\mathrm{H}_{3}\right), 0.82-0.96$ (átfedő $\mathrm{m}, 2 \mathrm{H}), 1.02(\mathrm{~m}, 1 \mathrm{H}), 1.14(\mathrm{~m}, 1 \mathrm{H}), 1.22-1.37$ (átfedő $\mathrm{m}, 5 \mathrm{H}), 1.48(\mathrm{~m}, 1 \mathrm{H}), 1.58-1.74$ (átfedő $\mathrm{m}, 5 \mathrm{H}), 2.02\left(\mathrm{~s}, 3 \mathrm{H}, \mathrm{Ac}-\mathrm{CH}_{3}\right), 2.15(\mathrm{~m}, 1 \mathrm{H}), 2.23(\mathrm{~d}, 1 \mathrm{H}, J=15.6 \mathrm{~Hz}$, az egyik 1$\left.\mathrm{H}_{2}\right), 2.43\left(\mathrm{~d}, 1 \mathrm{H}, J=15.6 \mathrm{~Hz}\right.$, a másik 1- $\left.\mathrm{H}_{2}\right), 2.50(\mathrm{dd}, 1 \mathrm{H}, J=19.1 \mathrm{~Hz}, J=12.5 \mathrm{~Hz}, \mathrm{az}$ egyik 4- $\mathrm{H}_{2}$ ), 2.87 (dd, $1 \mathrm{H}, J=19.1 \mathrm{~Hz}, J=4.8 \mathrm{~Hz}$, a másik 4- $\left.\mathrm{H}_{2}\right), 4.57$ (t, $1 \mathrm{H}, J=8.3 \mathrm{~Hz}$, 17-H), $7.41(\mathrm{~d}, 2 \mathrm{H}, J=8.1 \mathrm{~Hz})$ és $7.54(\mathrm{~d}, 2 \mathrm{H}, J=8.1 \mathrm{~Hz}): 3^{\prime \prime}-\mathrm{H}, 5^{\prime \prime}-\mathrm{H}$ és $2 "-\mathrm{H}, 6 "-\mathrm{H} ;{ }^{13} \mathrm{C}$ $\mathrm{NMR}\left(\mathrm{CDCl}_{3}, 125 \mathrm{MHz}\right): \delta_{\mathrm{C}}=11.4(\mathrm{C}-19), 11.9(\mathrm{C}-18), 20.6\left(\mathrm{CH}_{2}\right), 21.1\left(\mathrm{Ac}^{\left.-\mathrm{CH}_{3}\right), 23.4}\right.$ $\left(\mathrm{CH}_{2}\right), 27.5\left(\mathrm{CH}_{2}\right), 27.8\left(\mathrm{CH}_{2}\right), 30.8\left(\mathrm{CH}_{2}\right), 31.8(\mathrm{C}-4), 35.1(\mathrm{C}-8), 35.6(\mathrm{C}-10), 36.7(\mathrm{C}-16)$, 39.3 (C-1), 40.1 (C-5), 42.3 (C-13), 50.5 (C-14), 53.3 (C-9), 82.6 (C-17), 111.1 (C-2), 128.4 (2C) és 130.3 (2C): C-2", C-6" és C-3", C-5", 134.7 (C-1"), 136.5 (C-4"), 157.7 (C-3), 171.1 (Ac-CO) - a C-2' és C-4' jelek a tautoméria miatt nem láthatóak a spektrumon; ESI-MS: 496 $[\mathrm{M}+\mathrm{H}]^{+} ; \mathrm{C}_{29} \mathrm{H}_{35} \mathrm{ClN}_{2} \mathrm{O}_{3}$.

28c: IR $\left(\mathrm{cm}^{-1}\right)$ : 1732, 1661, 1615, 1602, 1510, 1235, 1020, 841, 792

${ }^{1} \mathrm{H} \mathrm{NMR}\left(\mathrm{CDCl}_{3}, 500 \mathrm{MHz}\right): \delta_{\mathrm{H}}=0.65\left(\mathrm{~s}, 3 \mathrm{H}, 19-\mathrm{H}_{3}\right), 0.74\left(\mathrm{~s}, 3 \mathrm{H}, 18-\mathrm{H}_{3}\right), 0.81(\mathrm{~m}, 1 \mathrm{H})$, $0.90(\mathrm{~m}, 1 \mathrm{H}), 1.01(\mathrm{~m}, 1 \mathrm{H}), 1.14(\mathrm{~m}, 1 \mathrm{H}), 1.19-1.37$ (átfedő $\mathrm{m}, 5 \mathrm{H}), 1.47(\mathrm{~m}, 1 \mathrm{H}), 1.57-1.73$ (átfedő m, 5H), $2.02\left(\mathrm{~s}, 3 \mathrm{H}, \mathrm{Ac}_{-} \mathrm{CH}_{3}\right), 2.15(\mathrm{~m}, 1 \mathrm{H}), 2.23(\mathrm{~d}, 1 \mathrm{H}, J=15.6 \mathrm{~Hz}$, az egyik 1$\left.\mathrm{H}_{2}\right), 2.43\left(\mathrm{~d}, 1 \mathrm{H}, J=15.6 \mathrm{~Hz}\right.$, a másik 1- $\left.\mathrm{H}_{2}\right), 2.49(\mathrm{dd}, 1 \mathrm{H}, J=19.3 \mathrm{~Hz}, J=12.3 \mathrm{~Hz}, \mathrm{az}$

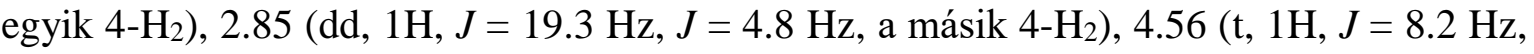
17-H), $7.47(\mathrm{~d}, 2 \mathrm{H}, J=8.1 \mathrm{~Hz})$ és $7.56(\mathrm{~d}, 2 \mathrm{H}, J=8.1 \mathrm{~Hz}): 3^{\prime \prime}-\mathrm{H}, 5^{\prime \prime}-\mathrm{H}$ és $2 "-\mathrm{H}, 6 "-\mathrm{H} ;{ }^{13} \mathrm{C}$ $\operatorname{NMR}\left(\mathrm{CDCl}_{3}, 125 \mathrm{MHz}\right): \delta_{\mathrm{C}}=11.3(\mathrm{C}-19), 11.9(\mathrm{C}-18), 20.6\left(\mathrm{CH}_{2}\right), 21.1\left(\mathrm{Ac}^{\left.-\mathrm{CH}_{3}\right), 23.4}\right.$ $\left(\mathrm{CH}_{2}\right), 27.5\left(\mathrm{CH}_{2}\right), 27.7\left(\mathrm{CH}_{2}\right), 30.8\left(\mathrm{CH}_{2}\right), 31.8(\mathrm{C}-4), 35.1(\mathrm{C}-8), 35.7(\mathrm{C}-10), 36.6(\mathrm{C}-16)$, 39.3 (C-1), 40.1 (C-5), 42.3 (C-13), 50.5 (C-14), 53.3 (C-9), 82.6 (C-17), 111.0 (C-2), 124.8 (C-4"), 130.5 (2C) és 131.4 (2C): C-2", C-6" és C-3", C-5", 135.5 (C-1"), 158.1 (C-3), 171.1 (Ac-CO) - a C-2' és C-4' jelek a tautoméria miatt nem láthatóak a spektrumon; ESI-MS: 540 $[\mathrm{M}+\mathrm{H}]^{+} ; \mathrm{C}_{29} \mathrm{H}_{35} \mathrm{BrN}_{2} \mathrm{O}_{3}$.

28d: IR ( $\left.\mathrm{cm}^{-1}\right)$ : 3097, 1726, 1670, 1604, 1585, 1565, 1418, 1236, 1011, 840, 790, 733 ${ }^{1} \mathrm{H} \mathrm{NMR}\left(\mathrm{CDCl}_{3}, 500 \mathrm{MHz}\right): \delta_{\mathrm{H}}=0.65\left(\mathrm{~s}, 3 \mathrm{H}, 19-\mathrm{H}_{3}\right), 0.74\left(\mathrm{~s}, 3 \mathrm{H}, 18-\mathrm{H}_{3}\right), 0.81(\mathrm{~m}, 1 \mathrm{H})$, $0.90(\mathrm{~m}, 1 \mathrm{H}), 1.01(\mathrm{~m}, 1 \mathrm{H}), 1.13(\mathrm{~m}, 1 \mathrm{H}), 1.20-1.37$ (átfedő $\mathrm{m}, 5 \mathrm{H}), 1.46(\mathrm{~m}, 1 \mathrm{H}), 1.58-1.73$ (átfedő m, 5H), $2.02\left(\mathrm{~s}, 3 \mathrm{H}, \mathrm{Ac}_{-} \mathrm{CH}_{3}\right), 2.15(\mathrm{~m}, 1 \mathrm{H}), 2.23(\mathrm{~d}, 1 \mathrm{H}, J=15.6 \mathrm{~Hz}$, az egyik 1$\left.\mathrm{H}_{2}\right), 2.45\left(\mathrm{~d}, 1 \mathrm{H}, J=15.6 \mathrm{~Hz}\right.$, a másik 1- $\left.\mathrm{H}_{2}\right), 2.50(\mathrm{dd}, 1 \mathrm{H}, J=19.2 \mathrm{~Hz}, J=12.2 \mathrm{~Hz}, \mathrm{az}$ egyik 4-H2), $2.86\left(\mathrm{dd}, 1 \mathrm{H}, J=19.2 \mathrm{~Hz}, J=4.8 \mathrm{~Hz}\right.$, a másik 4- $\left.\mathrm{H}_{2}\right), 4.57(\mathrm{t}, 1 \mathrm{H}, J=8.4 \mathrm{~Hz}$, 17-H), 7.12 (m, 2H, 3"-H és 5"-H), 7.60 (m, 2H, 2"-H és 6"-H); ${ }^{13} \mathrm{C} \mathrm{NMR}\left(\mathrm{CDCl}_{3}, 125\right.$ $\mathrm{MHz}): \delta_{\mathrm{C}}=11.3(\mathrm{C}-19), 11.9(\mathrm{C}-18), 20.6\left(\mathrm{CH}_{2}\right), 21.1\left(\mathrm{Ac}-\mathrm{CH}_{3}\right), 23.4\left(\mathrm{CH}_{2}\right), 27.4\left(\mathrm{CH}_{2}\right)$, $27.7\left(\mathrm{CH}_{2}\right), 30.8\left(\mathrm{CH}_{2}\right), 31.8(\mathrm{C}-4), 35.1(\mathrm{C}-8), 35.7(\mathrm{C}-10), 36.7(\mathrm{C}-16), 39.4(\mathrm{C}-1), 40.1$ (C-5), 42.3 (C-13), 50.5 (C-14), 53.3 (C-9), 82.6 (C-17), 111.1 (C-2), 115.3 (d, 2C, J = 21.7 Hz, C-3" és C-5"), 131.1 (d, 2C, $J=8.5$ Hz, C-2" és C-6"), 132.5 (C-1"), 158.0 (C-3), 163.8 (d, $J=251.2 \mathrm{~Hz}, \mathrm{C}-4 "), 171.2($ Ac-CO) - a C-2' és C-4' jelek a tautoméria miatt nem láthatóak a spektrumon; ESI-MS: $480[\mathrm{M}+\mathrm{H}]^{+} ; \mathrm{C}_{29} \mathrm{H}_{35} \mathrm{FN}_{2} \mathrm{O}_{3}$. 
28e: IR (cm $\left.{ }^{-1}\right)$ : 3112, 1731, 1644, 1614, 1521, 1344, 1322, 1216, 1101, 1022, 847, 792, 709 ${ }^{1} \mathrm{H}$ NMR $\left(\mathrm{CDCl}_{3}, 500 \mathrm{MHz}\right): \delta_{\mathrm{H}}=0.68\left(\mathrm{~s}, 3 \mathrm{H}, 19-\mathrm{H}_{3}\right), 0.74\left(\mathrm{~s}, 3 \mathrm{H}, 18-\mathrm{H}_{3}\right), 0.80-0.96$ (átfedő $\mathrm{m}, 2 \mathrm{H}), 1.02(\mathrm{~m}, 1 \mathrm{H}), 1.12(\mathrm{~m}, 1 \mathrm{H}), 1.21-1.38$ (átfedő $\mathrm{m}, 5 \mathrm{H}), 1.48(\mathrm{~m}, 1 \mathrm{H}), 1.59-1.74$ (átfedő m, 5H), $2.01\left(\mathrm{~s}, 3 \mathrm{H}, \mathrm{Ac}-\mathrm{CH}_{3}\right), 2.15(\mathrm{~m}, 1 \mathrm{H}), 2.23(\mathrm{~d}, 1 \mathrm{H}, J=15.6 \mathrm{~Hz}$, az egyik 1$\left.\mathrm{H}_{2}\right), 2.35\left(\mathrm{~d}, 1 \mathrm{H}, J=15.6 \mathrm{~Hz}\right.$, a másik 1- $\left.\mathrm{H}_{2}\right), 2.55(\mathrm{dd}, 1 \mathrm{H}, J=19.3 \mathrm{~Hz}, J=12.2 \mathrm{~Hz}, \mathrm{az}$ egyik 4-H 2 ), 2.89 (dd, $1 \mathrm{H}, J=19.3 \mathrm{~Hz}, J=4.5 \mathrm{~Hz}$, a másik 4- $\left.\mathrm{H}_{2}\right), 4.55$ (t, $1 \mathrm{H}, J=8.4 \mathrm{~Hz}$, 17-H), $7.76\left(\mathrm{~d}, 2 \mathrm{H}, J=8.4 \mathrm{~Hz}, 2^{\prime \prime}-\mathrm{H}\right.$ és 6"-H), $8.30(\mathrm{~d}, 2 \mathrm{H}, J=8.4 \mathrm{~Hz}, 3$ "-H és $5 "-\mathrm{H})$; ${ }^{13} \mathrm{C}$ $\mathrm{NMR}\left(\mathrm{CDCl}_{3}, 125 \mathrm{MHz}\right): \delta_{\mathrm{C}}=11.4(\mathrm{C}-19), 11.9(\mathrm{C}-18), 20.6\left(\mathrm{CH}_{2}\right), 21.1\left(\mathrm{Ac}^{\left.-\mathrm{CH}_{3}\right), 23.4}\right.$ $\left(\mathrm{CH}_{2}\right), 27.4\left(\mathrm{CH}_{2}\right), 27.7\left(\mathrm{CH}_{2}\right), 30.7\left(\mathrm{CH}_{2}\right), 31.6(\mathrm{C}-4), 35.1(\mathrm{C}-8), 35.6(\mathrm{C}-10), 36.6(\mathrm{C}-16)$, 39.0 (C-1), 40.0 (C-5), 42.3 (C-13), 50.5 (C-14), 53.2 (C-9), 82.6 (C-17), 111.3 (C-2), 123.4 (2C, C-2" és C-6"), 129.8 (2C, C-3" és C-5"), 142.5 (C-1"), 148.7 (2C, C-4" és C-3), 171.1 (Ac-CO) - a C-2' és C-4' jelek a tautoméria miatt nem láthatóak a spektrumon; ESI-MS: $506[\mathrm{M}+\mathrm{H}]^{+} ; \mathrm{C}_{29} \mathrm{H}_{35} \mathrm{~N}_{3} \mathrm{O}_{5}$.

28f: IR ( $\left.\mathrm{cm}^{-1}\right)$ : 1732, 1644, 1597, 1511, 1364, 1348, 1245, 1021, 837, 788

${ }^{1} \mathrm{H} \mathrm{NMR}\left(\mathrm{CDCl}_{3}, 500 \mathrm{MHz}\right): \delta_{\mathrm{H}}=0.64\left(\mathrm{~s}, 3 \mathrm{H}, 19-\mathrm{H}_{3}\right), 0.74\left(\mathrm{~s}, 3 \mathrm{H}, 18-\mathrm{H}_{3}\right), 0.84(\mathrm{~m}, 1 \mathrm{H})$, $0.93(\mathrm{~m}, 1 \mathrm{H}), 1.03(\mathrm{~m}, 1 \mathrm{H}), 1.15(\mathrm{~m}, 1 \mathrm{H}), 1.20-1.41$ (átfedő $\mathrm{m}, 5 \mathrm{H}), 1.48(\mathrm{~m}, 1 \mathrm{H}), 1.58-1.73$ (átfedő m, 5H), $2.02\left(\mathrm{~s}, 3 \mathrm{H}, \mathrm{Ac}-\mathrm{CH}_{3}\right), 2.15(\mathrm{~m}, 1 \mathrm{H}), 2.27(\mathrm{~d}, 1 \mathrm{H}, J=15.5 \mathrm{~Hz}$, az egyik 1$\mathrm{H}_{2}$ ), 2.46-2.53 (átfedő $\mathrm{m}, 2 \mathrm{H}$, a másik 1- $\mathrm{H}_{2}$ és az egyik 4- $\mathrm{H}_{2}$ ), 2.84 (dd, $1 \mathrm{H}, J=19.3 \mathrm{~Hz}, J$ $=4.7 \mathrm{~Hz}$, a másik 4-H $), 3.85\left(\mathrm{~s}, 3 \mathrm{H}, 4^{\prime \prime}-\mathrm{OMe}\right), 4.57(\mathrm{t}, 1 \mathrm{H}, J=8.4 \mathrm{~Hz}, 17-\mathrm{H}), 6.95(\mathrm{~d}, 2 \mathrm{H}$, $J=8.5 \mathrm{~Hz}, 3^{\prime \prime}-\mathrm{H}$ és $\left.5^{\prime \prime}-\mathrm{H}\right), 7.60\left(\mathrm{~d}, 2 \mathrm{H}, J=8.5 \mathrm{~Hz}, 2^{\prime \prime}-\mathrm{H}\right.$ és $\left.6 "-\mathrm{H}\right) ;{ }^{13} \mathrm{C} \mathrm{NMR}\left(\mathrm{CDCl}_{3}, 125\right.$ $\mathrm{MHz}): \delta_{\mathrm{C}}=11.3(\mathrm{C}-19), 11.9(\mathrm{C}-18), 20.7\left(\mathrm{CH}_{2}\right), 21.1\left(\mathrm{Ac}-\mathrm{CH}_{3}\right), 23.4\left(\mathrm{CH}_{2}\right), 27.4\left(\mathrm{CH}_{2}\right)$, $27.8\left(\mathrm{CH}_{2}\right), 30.8\left(\mathrm{CH}_{2}\right), 32.2(\mathrm{C}-4), 35.1(\mathrm{C}-8), 35.6(\mathrm{C}-10), 36.7(\mathrm{C}-16), 39.4(\mathrm{C}-1), 40.2$ (C-5), 42.4 (C-13), 50.6 (C-14), 53.4 (C-9), 55.3 (4"-OMe), 82.7 (C-17), 110.9 (C-2), 113.5 (2C, C-3" és C-5"), 128.4 (C-1"), 130.9 (2C, C-2" és C-6"), 158.0 (C-3), 161.3 (C-4"), 171.1 (Ac-CO) - a C-2' és C-4' jelek a tautoméria miatt nem láthatóak a spektrumon; ESI-MS: 491 $[\mathrm{M}+\mathrm{H}]^{+} ; \mathrm{C}_{30} \mathrm{H}_{38} \mathrm{~N}_{2} \mathrm{O}_{4}$.

28g: IR $\left(\mathrm{cm}^{-1}\right)$ : 3096, 1734, 1658, 1610, 1431, 1368, 1237, 1021, 829, 791;

${ }^{1} \mathrm{H} \mathrm{NMR}\left(\mathrm{CDCl}_{3}, 500 \mathrm{MHz}\right): \delta_{\mathrm{H}}=0.65\left(\mathrm{~s}, 3 \mathrm{H}, 19-\mathrm{H}_{3}\right), 0.74\left(\mathrm{~s}, 3 \mathrm{H}, 18-\mathrm{H}_{3}\right), 0.82(\mathrm{~m}, 1 \mathrm{H})$, $0.92(\mathrm{~m}, 1 \mathrm{H}), 1.02(\mathrm{~m}, 1 \mathrm{H}), 1.14(\mathrm{~m}, 1 \mathrm{H}), 1.20-1.39$ (átfedő $\mathrm{m}, 5 \mathrm{H}), 1.47(\mathrm{~m}, 1 \mathrm{H}), 1.58-1.73$ (átfedő m, 5H), $2.02\left(\mathrm{~s}, 3 \mathrm{H}, \mathrm{Ac}-\mathrm{CH}_{3}\right), 2.14(\mathrm{~m}, 1 \mathrm{H}), 2.25(\mathrm{~d}, 1 \mathrm{H}, J=15.6 \mathrm{~Hz}$, az egyik 1$\mathrm{H}_{2}$ ), 2.39 (s, 3H, 4"- $\mathrm{CH}_{3}$ ), 2.46-2.51 (átfedő m, 2H, a másik 1- $\mathrm{H}_{2}$ és az egyik 4- $\mathrm{H}_{2}$ ), 2.85 (dd, $1 \mathrm{H}, J=19.4 \mathrm{~Hz}, J=5.0 \mathrm{~Hz}$, a másik 4-H2), 4.57 (t, 1H, $J=8.4 \mathrm{~Hz}, 17-\mathrm{H}), 7.24$ (d, 2H, $J=7.9 \mathrm{~Hz}, 3 "$-H és $\left.5^{\prime \prime}-\mathrm{H}\right), 7.49(\mathrm{~d}, 2 \mathrm{H}, J=7.9 \mathrm{~Hz}, 2 "-\mathrm{H}$ és $6 "-\mathrm{H}) ;{ }^{13} \mathrm{C} \mathrm{NMR}\left(\mathrm{CDCl}_{3}, 125\right.$

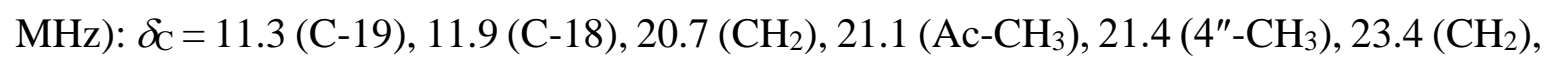
$27.4\left(\mathrm{CH}_{2}\right), 27.8\left(\mathrm{CH}_{2}\right), 30.8\left(\mathrm{CH}_{2}\right), 32.3(\mathrm{C}-4), 35.1(\mathrm{C}-8), 35.6(\mathrm{C}-10), 36.7(\mathrm{C}-16), 39.4$ (C-1), 40.3 (C-5), 42.4 (C-13), 50.6 (C-14), 53.3 (C-9), 82.7 (C-17), 111.1 (C-2), 128.9 (4C, C-2", C-6" és C-3", C-5"), 133.4 (C-1"), 140.5 (C-4"), 158.2 (C-3), 171.1 (Ac-CO) - the signals of C-2' és C-4' cannot be detected; ESI-MS: $433[\mathrm{M}+\mathrm{H}]^{+} ; \mathrm{C}_{28} \mathrm{H}_{36} \mathrm{~N}_{2} \mathrm{O}_{2}$.

29a: IR ( $\left.\mathrm{cm}^{-1}\right)$ : 3394, 1638, 1612, 1540, 1495, 1418, 1387, 1364, 1027, 794, 775, 703

${ }^{1} \mathrm{H} \mathrm{NMR}\left(\mathrm{CDCl}_{3}, 500 \mathrm{MHz}\right): \delta_{\mathrm{H}}=0.67(\mathrm{~s}, 3 \mathrm{H})$ és $0.69(\mathrm{~s}, 3 \mathrm{H}): 19-\mathrm{H}_{3}$ és $18-\mathrm{H}_{3}, 0.80(\mathrm{~m}, 1 \mathrm{H})$, 0.85-0.97 (átfedő m, 2H), 1.04 (m, 1H), 1.21-1.42 (átfedő m, 6H), 1.57-1.64 (átfedő m, 3H), 
$1.74(\mathrm{~m}, 2 \mathrm{H}), 2.04(\mathrm{~m}, 1 \mathrm{H}), 2.23\left(\mathrm{~d}, 1 \mathrm{H}, J=15.6 \mathrm{~Hz}\right.$, az egyik 1- $\left.\mathrm{H}_{2}\right), 2.47-2.55$ (átfedő m, $2 \mathrm{H}$, a másik 1- $\mathrm{H}_{2}$ és az egyik 4- $\left.\mathrm{H}_{2}\right), 2.86\left(\mathrm{dd}, 1 \mathrm{H}, J=19.4 \mathrm{~Hz}, J=4.9 \mathrm{~Hz}\right.$, a másik 4- $\left.\mathrm{H}_{2}\right)$, 3.62 (t, 1H, $J=8.4 \mathrm{~Hz}, 17-\mathrm{H}), 7.46$ (m, 3H, 3"-H, 4"-H és 5"-H), 7.57 (d, 2H, $J=7.4 \mathrm{~Hz}$, 2"-H és 6"-H); ${ }^{13} \mathrm{C} \mathrm{NMR}\left(\mathrm{CDCl}_{3}, 125 \mathrm{MHz}\right): \delta_{\mathrm{C}}=11.0$ és 11.4: C-18 és C-19, $20.7\left(\mathrm{CH}_{2}\right)$, $23.3\left(\mathrm{CH}_{2}\right), 27.8\left(\mathrm{CH}_{2}\right), 30.5\left(\mathrm{CH}_{2}\right), 30.9\left(\mathrm{CH}_{2}\right), 32.1(\mathrm{C}-4), 35.4(\mathrm{C}-8), 35.6(\mathrm{C}-10), 36.5$ (C-16), 39.3 (C-1), 40.3 (C-5), 42.7 (C-13), 50.8 (C-14), 53.5 (C-9), 81.8 (C-17), 111.2 (C2), 128.2 (2C) és 128.8 (2C): C-2", C-6" és C-3" és C-5", 130.2 (C-4"), 135.8 (C-1"), 157.7 (C-3) - a C-2' és C-4' jelek a tautoméria miatt nem láthatóak a spektrumon; ESI-MS: 419 $[\mathrm{M}+\mathrm{H}]^{+} ; \mathrm{C}_{27} \mathrm{H}_{34} \mathrm{~N}_{2} \mathrm{O}_{2}$.

29b: IR ( $\left.\mathrm{cm}^{-1}\right)$ : 3384, 1637, 1611, 1540, 1491, 1418, 1385, 1015, 833, 792

${ }^{1} \mathrm{H}$ NMR $\left(\mathrm{CDCl}_{3}, 500 \mathrm{MHz}\right): \delta_{\mathrm{H}}=0.66\left(\mathrm{~s}, 3 \mathrm{H}, 19-\mathrm{H}_{3}\right), 0.69\left(\mathrm{~s}, 3 \mathrm{H}, 18-\mathrm{H}_{3}\right), 0.80(\mathrm{~m}, 1 \mathrm{H})$, 0.86-0.96 (átfedő m, 2H), 1.05 (m, 1H), 1.20-1.45 (átfedő m, 6H), 1.58-1.65 (átfedő m, $3 \mathrm{H}$ ), $1.74(\mathrm{~m}, 2 \mathrm{H}), 2.05(\mathrm{~m}, 1 \mathrm{H}), 2.22\left(\mathrm{~d}, 1 \mathrm{H}, J=15.6 \mathrm{~Hz}\right.$, az egyik $\left.1-\mathrm{H}_{2}\right), 2.43(\mathrm{~d}, 1 \mathrm{H}, J=15.6$

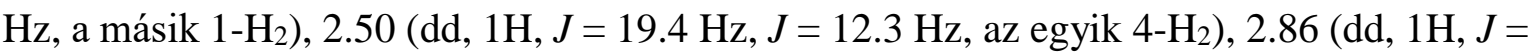
$19.4 \mathrm{~Hz}, J=4.8 \mathrm{~Hz}$, a másik 4-H $\mathrm{H}_{2}, 3.62(\mathrm{t}, 1 \mathrm{H}, J=8.5 \mathrm{~Hz}, 17-\mathrm{H}), 7.41(\mathrm{~d}, 2 \mathrm{H}, J=8.1 \mathrm{~Hz})$ és $7.54(\mathrm{~d}, 2 \mathrm{H}, J=8.1 \mathrm{~Hz}): 3^{\prime \prime}-\mathrm{H}, 5^{\prime \prime}-\mathrm{H}$ és $2^{\prime \prime}-\mathrm{H}, 6 "-\mathrm{H} ;{ }^{13} \mathrm{C} \mathrm{NMR}\left(\mathrm{CDCl}_{3}, 125 \mathrm{MHz}\right): \delta_{\mathrm{C}}=$ 11.0 és 11.4: C-18 és C-19, $20.8\left(\mathrm{CH}_{2}\right), 23.3\left(\mathrm{CH}_{2}\right), 27.8\left(\mathrm{CH}_{2}\right), 30.5\left(\mathrm{CH}_{2}\right), 30.8\left(\mathrm{CH}_{2}\right)$, 31.8 (C-4), 35.3 (C-8), 35.7 (C-10), 36.5 (C-16), 39.3 (C-1), 40.2 (C-5), 42.7 (C-13), 50.8 (C-14), 53.4 (C-9), 81.8 (C-17), 111.1 (C-2), 128.5 (2C) és 130.3 (2C): C-2", C-6" és C-3", C-5", 134.7 (C-1"), 136.5 (C-4"), 157.6 (C-3) - a C-2' és C-4' jelek a tautoméria miatt nem láthatóak a spektrumon; ESI-MS: $453[\mathrm{M}+\mathrm{H}]^{+} ; \mathrm{C}_{27} \mathrm{H}_{33} \mathrm{ClN}_{2} \mathrm{O}_{2}$.

29c: IR ( $\left.\mathrm{cm}^{-1}\right)$ : 3385, 3096, 1656, 1612, 1588, 1568, 1011, 834, 786

${ }^{1} \mathrm{H} \mathrm{NMR}\left(\mathrm{CDCl}_{3}, 500 \mathrm{MHz}\right): \delta_{\mathrm{H}}=0.66\left(\mathrm{~s}, 3 \mathrm{H}, 19-\mathrm{H}_{3}\right), 0.69\left(\mathrm{~s}, 3 \mathrm{H}, 18-\mathrm{H}_{3}\right), 0.80(\mathrm{~m}, 1 \mathrm{H})$, 0.86-0.96 (átfedő m, 2H), 1.04 (m, 1H), 1.20-1.43 (átfedő m, 6H), 1.57-1.65 (átfedő m, 3H), $1.75(\mathrm{~m}, 2 \mathrm{H}), 2.05(\mathrm{~m}, 1 \mathrm{H}), 2.22\left(\mathrm{~d}, 1 \mathrm{H}, J=15.5 \mathrm{~Hz}\right.$, az egyik 1- $\left.\mathrm{H}_{2}\right), 2.43(\mathrm{~d}, 1 \mathrm{H}, J=15.5$

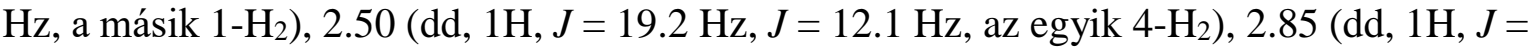
$19.2 \mathrm{~Hz}, J=5.0 \mathrm{~Hz}$, a másik 4-H $\mathrm{H}_{2}, 3.62(\mathrm{t}, 1 \mathrm{H}, J=8.5 \mathrm{~Hz}, 17-\mathrm{H}), 7.47(\mathrm{~d}, 2 \mathrm{H}, J=8.0 \mathrm{~Hz})$ és $7.56(\mathrm{~d}, 2 \mathrm{H}, J=8.0 \mathrm{~Hz}): 3^{\prime \prime}-\mathrm{H}, 5^{\prime \prime}-\mathrm{H}$ és $2^{\prime \prime}-\mathrm{H}, 6 "-\mathrm{H} ;{ }^{13} \mathrm{C} \mathrm{NMR}\left(\mathrm{CDCl}_{3}, 125 \mathrm{MHz}\right): \delta_{\mathrm{C}}=$ 11.0 és 11.4: C-18 és C-19, $20.8\left(\mathrm{CH}_{2}\right), 23.3\left(\mathrm{CH}_{2}\right), 27.8\left(\mathrm{CH}_{2}\right), 30.4\left(\mathrm{CH}_{2}\right), 30.8\left(\mathrm{CH}_{2}\right)$, 31.7 (C-4), 35.3 (C-8), 35.7 (C-10), 36.5 (C-16), 39.3 (C-1), 40.2 (C-5), 42.7 (C-13), 50.8 (C-14), 53.4 (C-9), 81.8 (C-17), 111.1 (C-2), 124.8 (C-4"), 130.5 (2C) és 131.4 (2C): C-2", C-6" és C-3", C-5", 135.5 (C-1"), 158.2 (C-3) - a C-2' és C-4' jelek a tautoméria miatt nem láthatóak a spektrumon; ESI-MS: $498[\mathrm{M}+\mathrm{H}]^{+} ; \mathrm{C}_{27} \mathrm{H}_{33} \mathrm{BrN}_{2} \mathrm{O}_{2}$.

29d: IR ( $\left.\mathrm{cm}^{-1}\right): 3370,1644,1603,1556,1506,1229,1157,840,808,793$

${ }^{1} \mathrm{H} \mathrm{NMR}\left(\mathrm{CDCl}_{3}, 500 \mathrm{MHz}\right): \delta_{\mathrm{H}}=0.67\left(\mathrm{~s}, 3 \mathrm{H}, 19-\mathrm{H}_{3}\right), 0.71\left(\mathrm{~s}, 3 \mathrm{H}, 18-\mathrm{H}_{3}\right), 0.81(\mathrm{~m}, 1 \mathrm{H})$, 0.86-0.98 (átfedő m, 2H), 1.07 (m, 1H), 1.22-1.46 (átfedő m, 6H), 1.57-1.64 (átfedő m, 3H), $1.74(\mathrm{~m}, 2 \mathrm{H}), 2.06(\mathrm{~m}, 1 \mathrm{H}), 2.22\left(\mathrm{~d}, 1 \mathrm{H}, J=15.6 \mathrm{~Hz}\right.$, az egyik 1- $\left.\mathrm{H}_{2}\right), 2.46-2.52$ (átfedő m, $2 \mathrm{H}$, a másik $1-\mathrm{H}_{2}$ és az egyik 4- $\left.\mathrm{H}_{2}\right), 2.83\left(\mathrm{dd}, 1 \mathrm{H}, J=19.6 \mathrm{~Hz}, J=5.0 \mathrm{~Hz}\right.$, a másik 4- $\left.\mathrm{H}_{2}\right)$, $3.63(\mathrm{t}, 1 \mathrm{H}, J=8.5 \mathrm{~Hz}, 17-\mathrm{H}), 7.13\left(\mathrm{~m}, 2 \mathrm{H}, 3 "-\mathrm{H}\right.$ és 5"-H), $7.61(\mathrm{~m}, 2 \mathrm{H}, 2$ "-H és $6 "-\mathrm{H}) ;{ }^{13} \mathrm{C}$ $\mathrm{NMR}\left(\mathrm{CDCl}_{3}, 125 \mathrm{MHz}\right): \delta_{\mathrm{C}}=11.0$ és 11.3: C-18 és C-19, $20.7\left(\mathrm{CH}_{2}\right), 23.3\left(\mathrm{CH}_{2}\right), 27.8$ $\left(\mathrm{CH}_{2}\right), 30.4\left(\mathrm{CH}_{2}\right), 30.9\left(\mathrm{CH}_{2}\right), 32.8(\mathrm{C}-4), 35.3(\mathrm{C}-8), 35.7$ (C-10), $36.5(\mathrm{C}-16), 39.5(\mathrm{C}-1)$, 
40.3 (C-5), 42.7 (C-13), 50.8 (C-14), 53.5 (C-9), 81.8 (C-17), 111.0 (C-2), 115.2 (d, 2C, $J=$ $20.1 \mathrm{~Hz}, \mathrm{C}-3^{\prime \prime}$ és C-5"), 131.0 (d, 2C, $J=7.8 \mathrm{~Hz}, \mathrm{C}-2^{\prime \prime}$ és C-6"), 132.5 (C-1"), 159.0 (C-3), 163.7 (d, $\left.J=250.5 \mathrm{~Hz}, \mathrm{C}-4^{\prime \prime}\right)$ - a C-2' és C-4' jelek a tautoméria miatt nem láthatóak a spektrumon; ESI-MS: $437[\mathrm{M}+\mathrm{H}]^{+} ; \mathrm{C}_{27} \mathrm{H}_{33} \mathrm{FN}_{2} \mathrm{O}_{2}$.

29e: IR ( $\left.\mathrm{cm}^{-1}\right)$ : 3354, 1650, 1558, 1520, 1344, 1014, 847, 811, 795, 709

${ }^{1} \mathrm{H} \mathrm{NMR}\left(\mathrm{CDCl}_{3}, 500 \mathrm{MHz}\right): \delta_{\mathrm{H}}=0.70\left(\mathrm{~s}, 6 \mathrm{H}, 19-\mathrm{H}_{3}\right.$ és $\left.18-\mathrm{H}_{3}\right), 0.82(\mathrm{~m}, 1 \mathrm{H}), 0.86-0.98$ (átfedő m, 2H), $1.05(\mathrm{~m}, 1 \mathrm{H}), 1.23-1.45$ (átfedő $\mathrm{m}, 6 \mathrm{H}$ ), 1.57-1.65 (átfedő $\mathrm{m}, 3 \mathrm{H}$ ), 1.76 (m, 2H), $2.06(\mathrm{~m}, 1 \mathrm{H}), 2.23\left(\mathrm{~d}, 1 \mathrm{H}, J=15.6 \mathrm{~Hz}\right.$, az egyik $\left.1-\mathrm{H}_{2}\right), 2.40(\mathrm{~d}, 1 \mathrm{H}, J=15.6 \mathrm{~Hz}$, a másik 1- $\left.\mathrm{H}_{2}\right), 2.54\left(\mathrm{dd}, 1 \mathrm{H}, J=19.1 \mathrm{~Hz}, J=12.3 \mathrm{~Hz}\right.$, az egyik 4- $\left.\mathrm{H}_{2}\right), 2.85(\mathrm{dd}, 1 \mathrm{H}, J=19.1$ $\mathrm{Hz}, J=5.3 \mathrm{~Hz}$, a másik 4-H2), $3.64(\mathrm{t}, 1 \mathrm{H}, J=8.5 \mathrm{~Hz}, 17-\mathrm{H}), 7.76\left(\mathrm{~d}, 2 \mathrm{H}, J=8.5 \mathrm{~Hz}, 2^{\prime \prime}-\mathrm{H}\right.$ és 6"-H), $8.32\left(\mathrm{~d}, 2 \mathrm{H}, J=8.5 \mathrm{~Hz}, 3^{\prime \prime}-\mathrm{H}\right.$ és 5"-H); ESI-MS: $464[\mathrm{M}+\mathrm{H}]^{+} ; \mathrm{C}_{27} \mathrm{H}_{33} \mathrm{~N}_{3} \mathrm{O}_{4}$.

29f: IR ( $\left.\mathrm{cm}^{-1}\right)$ : 3370, 1640, 1560, 1510, 1252, 1172, 1078, 836, 790

${ }^{1} \mathrm{H} \mathrm{NMR}\left(\mathrm{CDCl}_{3}, 500 \mathrm{MHz}\right): \delta 0.64\left(\mathrm{~s}, 3 \mathrm{H}, 19-\mathrm{H}_{3}\right), 0.69$ (s, 3H, 18- $\left.\mathrm{H}_{3}\right), 0.80(\mathrm{~m}, 1 \mathrm{H}), 0.85-$ 0.96 (átfedő m, 2H), 1.05 (m, 1H), 1.20-1.41 (átfedő m, 6H), 1.57-1.64 (átfedő m, 3H), 1.75 $(\mathrm{m}, 2 \mathrm{H}), 2.05(\mathrm{~m}, 1 \mathrm{H}), 2.26\left(\mathrm{~d}, 1 \mathrm{H}, J=15.5 \mathrm{~Hz}\right.$, az egyik 1- $\left.\mathrm{H}_{2}\right), 2.46-2.53$ (átfedő $\mathrm{m}, 2 \mathrm{H}$, a másik 1- $\mathrm{H}_{2}$ és az egyik 4- $\left.\mathrm{H}_{2}\right), 2.84\left(\mathrm{dd}, 1 \mathrm{H}, J=19.3 \mathrm{~Hz}, J=4.7 \mathrm{~Hz}\right.$, a másik 4- $\left.\mathrm{H}_{2}\right), 3.61$ (t, $1 \mathrm{H}, J=8.4 \mathrm{~Hz}, 17-\mathrm{H}$ ), 3.87 (s, 3H, 4"-OMe), 6.93 (d, 2H, $J=8.5 \mathrm{~Hz}, 3 "-\mathrm{H}$ és 5"-H), 7.58 $\left(\mathrm{d}, 2 \mathrm{H}, J=8.5 \mathrm{~Hz}, 2^{\prime \prime}-\mathrm{H}\right.$ és $\left.6 "-\mathrm{H}\right) ;{ }^{13} \mathrm{C} \mathrm{NMR}\left(\mathrm{CDCl}_{3}, 125 \mathrm{MHz}\right): \delta 11.0$ és $11.3: \mathrm{C}-18$ és C19, $20.8\left(\mathrm{CH}_{2}\right), 23.3\left(\mathrm{CH}_{2}\right), 27.8\left(\mathrm{CH}_{2}\right), 30.4\left(\mathrm{CH}_{2}\right), 30.9\left(\mathrm{CH}_{2}\right), 32.2(\mathrm{C}-4), 35.3(\mathrm{C}-8), 35.7$ (C-10), 36.5 (C-16), 39.7 (C-1), 40.3 (C-5), 42.7 (C-13), 50.8 (C-14), 53.5 (C-9), 55.3 (4"OMe), 81.8 (C-17), 110.9 (C-2), 113.5 (2C, C-3" és C-5"), 128.4 (C-1"), 130.9 (2C, C-2" és C-6"), 158.7 (C-3), $161.1\left(\mathrm{C}-4^{\prime \prime}\right)$ - a C-2' és C-4' jelek a tautoméria miatt nem láthatóak a spektrumon; ESI-MS: $449[\mathrm{M}+\mathrm{H}]^{+} ; \mathrm{C}_{28} \mathrm{H}_{36} \mathrm{~N}_{2} \mathrm{O}_{3}$.

29g: IR ( $\left.\mathrm{cm}^{-1}\right)$ : 3384, 1639, 1606, 1540, 1509, 1184, 960, 943, 821, 790

${ }^{1} \mathrm{H}$ NMR $\left(\mathrm{CDCl}_{3}, 500 \mathrm{MHz}\right): \delta 0.65$ (s, 3H, 19-H $), 0.69$ (s, 3H, 18- $\left.\mathrm{H}_{3}\right), 0.80(\mathrm{~m}, 1 \mathrm{H}), 0.85-$ 0.96 (átfedő $\mathrm{m}, 2 \mathrm{H}), 1.05$ (m, 1H), 1.20-1.41 (átfedő m, 6H), 1.57-1.64 (átfedő m, 3H), 1.73 $(\mathrm{m}, 2 \mathrm{H}), 2.04(\mathrm{~m}, 1 \mathrm{H}), 2.23(\mathrm{~d}, 1 \mathrm{H}, J=15.6 \mathrm{~Hz}$, az egyik 1-H 2$), 2.39$ (s, 3H, 4"-CH $), 2.46-$ 2.52 (átfedő $\mathrm{m}, 2 \mathrm{H}$, a másik 1- $\mathrm{H}_{2}$ és az egyik 4-H2), 2.85 (dd, $1 \mathrm{H}, J=19.6 \mathrm{~Hz}, J=5.0 \mathrm{~Hz}$, a másik 4-H2), 3.61 (t, 1H, $J=8.4 \mathrm{~Hz}, 17-\mathrm{H}), 7.24$ (d, 2H, $J=7.8 \mathrm{~Hz}, 3$ "-H és 5"-H), 7.48 (d, $2 \mathrm{H}, J=7.8 \mathrm{~Hz}, 2^{\prime \prime}$-H és $\left.6 "-\mathrm{H}\right) ;{ }^{13} \mathrm{C} \mathrm{NMR}\left(\mathrm{CDCl}_{3}, 125 \mathrm{MHz}\right): \delta 11.0$ és 11.3: C-18 és C-19, $20.7\left(\mathrm{CH}_{2}\right), 21.4\left(4 "-\mathrm{CH}_{3}\right), 23.3\left(\mathrm{CH}_{2}\right), 27.8\left(\mathrm{CH}_{2}\right), 30.4\left(\mathrm{CH}_{2}\right), 30.9\left(\mathrm{CH}_{2}\right), 32.2(\mathrm{C}-4), 35.3$ (C-8), 35.6 (C-10), 36.5 (C-16), 39.4 (C-1), 40.3 (C-5), 42.7 (C-13), 50.8 (C-14), 53.5 (C9), 81.8 (C-17), 111.1 (C-2), 128.9 (4C, C-2", C-6" és C-3", C-5"), 133.4 (C-1"), 140.4 (C4"), 158.2 (C-3) - a C-2' és C-4' jelek a tautoméria miatt nem láthatóak a spektrumon; ESIMS: $433[\mathrm{M}+\mathrm{H}]^{+} ; \mathrm{C}_{28} \mathrm{H}_{36} \mathrm{~N}_{2} \mathrm{O}_{2}$. 
Az in vitro hatástani vizsgálatok részletes eredményei

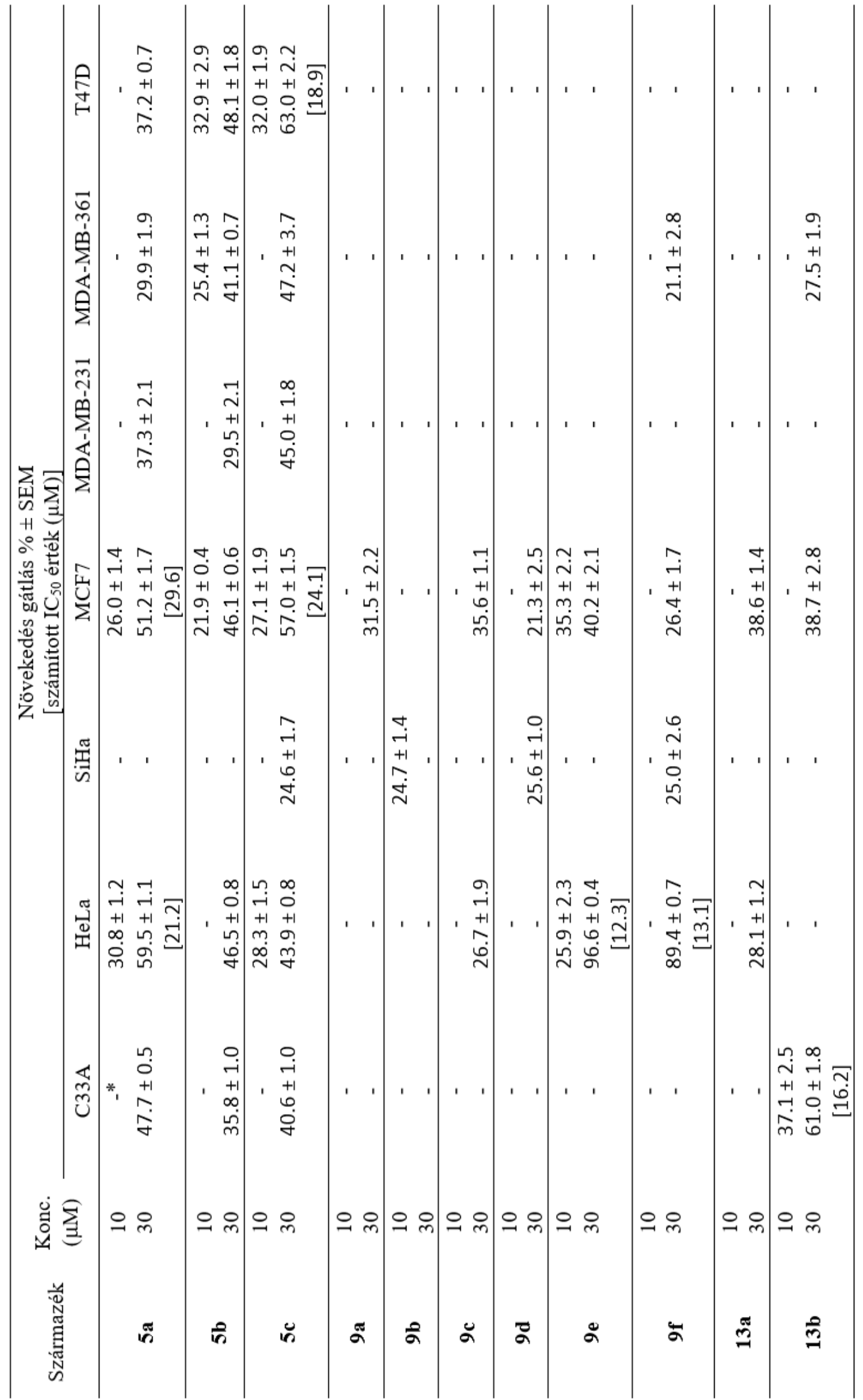




\begin{tabular}{|c|c|c|c|c|c|c|c|c|c|c|c|}
\hline $\begin{array}{l}\stackrel{-}{-} \\
\text { '+1 } \\
\sigma \\
\text { gे }\end{array}$ & $\begin{array}{ll}\dot{j} & \dot{0} \\
\dot{\mu} & \dot{a}\end{array}$ & 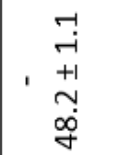 & $\begin{array}{l}\infty \\
\stackrel{\infty}{0} \\
1 \\
+1 \\
0 \\
i \\
\end{array}$ & 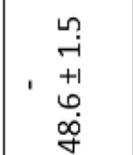 & $\mid \begin{array}{ll}\dot{r} & 0 \\
\dot{y} & \dot{A}\end{array}$ & $\begin{array}{ll}\dot{1} & 0 \\
\dot{a} & \dot{a}\end{array}$ & 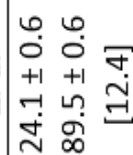 & $\begin{array}{l}\stackrel{9}{r} \\
+1 \\
+1 \\
\stackrel{+1}{n}\end{array}$ & 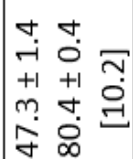 & 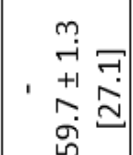 & 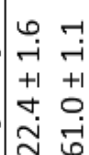 \\
\hline 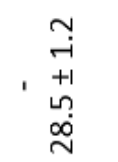 & $\begin{array}{ll}\dot{C} & \dot{0} \\
\dot{a} & \dot{d}\end{array}$ & 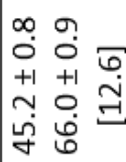 & 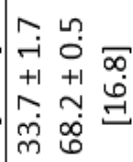 & 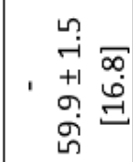 & $\mid \begin{array}{ll}\dot{C} & \dot{0} \\
\dot{d} & \dot{a}\end{array}$ & $\begin{array}{ll}\dot{r} & \dot{0} \\
\dot{4} & \dot{4}\end{array}$ & $\begin{array}{c}0 \\
\stackrel{+}{+} \\
++1 \\
0 \\
0 \\
\infty \\
+\end{array}$ & 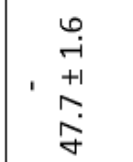 & 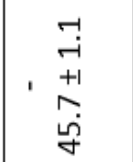 & 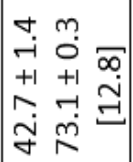 & 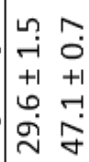 \\
\hline 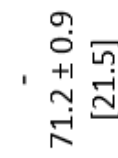 & $\begin{array}{lr}\dot{r} & \dot{\tau} \\
\dot{a} & \dot{a}\end{array}$ & $\begin{array}{l}\hat{i} \\
\text { +1 } \\
\stackrel{+}{+} \\
\dot{\sim}\end{array}$ & $\begin{array}{l}\stackrel{-}{-1} \\
\stackrel{+}{+1} \\
0 \\
0 \\
\infty \\
\dot{+}\end{array}$ & $\begin{array}{l}9 \\
\dot{0} \\
1+1 \\
m \\
0 \\
\dot{m}\end{array}$ & $\begin{array}{ll}\dot{r} & \dot{0} \\
\dot{y} & \dot{A}\end{array}$ & $\begin{array}{l}\dot{r} \\
\dot{y} \\
\dot{A}\end{array}$ & 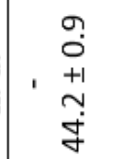 & $\begin{array}{l}-1 \\
\dot{m} \\
++1 \\
\stackrel{+}{\hat{m}}\end{array}$ & $\begin{array}{l}0 \\
\stackrel{+}{+} \\
1+1 \\
m \\
\stackrel{+}{+}\end{array}$ & 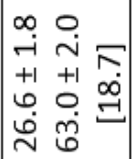 & 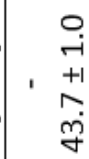 \\
\hline \begin{tabular}{c}
$\hat{0}$ \\
0 \\
+1 \\
+1 \\
\multirow{+}{+}{}
\end{tabular} & $\begin{array}{ll}\dot{C} & \dot{j} \\
\dot{d} & \dot{a}\end{array}$ & 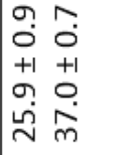 & 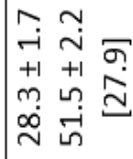 & 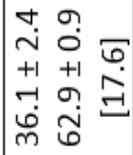 & $\mid \begin{array}{ll}\dot{\sigma} & \dot{0} \\
\dot{y} & \dot{\theta}\end{array}$ & $\begin{array}{ll}\dot{1} & \dot{0} \\
\dot{y} & \dot{y}\end{array}$ & $\begin{array}{l}\tilde{c} \\
0 \\
++1 \\
m \\
\tilde{j} \\
\tilde{\sigma}\end{array}$ & 1 & 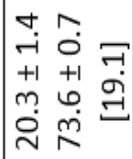 & 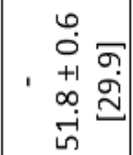 & $\begin{array}{l}0 \\
+ \\
+1 \\
+1 \\
\infty \\
\stackrel{1}{r}\end{array}$ \\
\hline $\begin{array}{l}\hat{0} \\
\text { + } \\
\text { +1 } \\
\text { ñ } \\
\text { ñ }\end{array}$ & $\begin{array}{ll}\dot{r} & \dot{\tau} \\
\dot{a} & \dot{a}\end{array}$ & 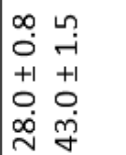 & 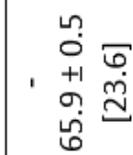 & $\begin{array}{l}\stackrel{0}{i} \\
i+1 \\
m \\
\dot{m}\end{array}$ & $\mid \begin{array}{ll}\dot{r} & 0 \\
\dot{y} & \dot{A}\end{array}$ & $\begin{array}{ll}\dot{r} & \dot{0} \\
\dot{y} & \dot{4}\end{array}$ & $\begin{array}{l}0 \\
\stackrel{+}{+} \\
++1 \\
\infty \\
\stackrel{+}{+}\end{array}$ & $\begin{array}{l}\stackrel{n}{+} \\
\stackrel{+}{+1} \\
\stackrel{+}{+} \\
\stackrel{g}{\sigma}\end{array}$ & $\begin{array}{l}\stackrel{+}{+} \\
\stackrel{+}{+1} \\
m \\
\stackrel{m}{m}\end{array}$ & $\begin{array}{l}\hat{o} \\
0 \\
1+1 \\
\dot{+} \\
\dot{m}\end{array}$ & \begin{tabular}{c}
$\stackrel{-1}{\pi}$ \\
+1 \\
$\stackrel{+1}{5}$ \\
\multirow{5}{*}{}
\end{tabular} \\
\hline 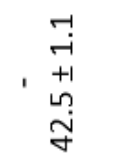 & $\begin{array}{ll}\dot{C} & \dot{0} \\
\dot{A} & \dot{d}\end{array}$ & $\begin{array}{ll}1 & 9 \\
0 & 0 \\
+1 & +1 \\
+1 & 0 \\
0 & 0 \\
\infty & \dot{j} \\
m & m\end{array}$ & $\begin{array}{c}\hat{i} \\
+1 \\
+0 \\
0 \\
\infty \\
+\end{array}$ & 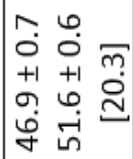 & $\mid \begin{array}{ll}\dot{r} & \dot{\sigma} \\
\dot{A} & \dot{A}\end{array}$ & $\begin{array}{l}\dot{r} \dot{0} \\
\dot{y} \dot{d}\end{array}$ & ' & 11 & 11 & 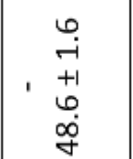 & 1 \\
\hline $\begin{array}{l}m \\
\stackrel{n}{+} \\
++1 \\
\sigma \\
\infty \\
\infty\end{array}$ & $\begin{array}{l}\dot{r} \\
\dot{A} \\
\dot{A}\end{array}$ & $\begin{array}{l}\sim \\
\stackrel{n}{+} \\
+1 \\
0 \\
\stackrel{+}{m}\end{array}$ & 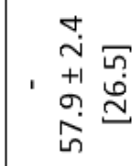 & 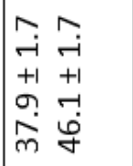 & $\begin{array}{ll}\dot{r} & \dot{0} \\
\dot{I} & \dot{A}\end{array}$ & $\begin{array}{ll}\dot{y} & \dot{0} \\
\dot{a} & \dot{a}\end{array}$ & 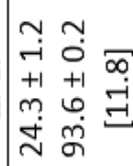 & 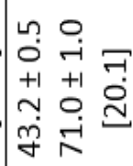 & 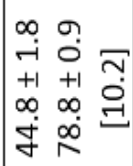 & 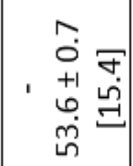 & $\begin{array}{ll}n & 0 \\
0 & 0 \\
+1 & +1 \\
+1 & + \\
& 0 \\
& 0\end{array}$ \\
\hline 으요 & 으 용 & $\circ \circ$ & 으 & $\circ \circ$ & 으 요 & $\circ$ 요 & $\circ 0$ & 으 음 & $\circ \circ$ & $\circ \circ$ & $\circ \circ$ \\
\hline$\stackrel{\mathscr{m}}{2}$ & 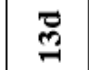 & 2. & 3 & $\stackrel{m}{2}$ & bo & लै & $\stackrel{\text { I }}{\square}$ & f & $\underset{J}{q}$ & I & $\stackrel{Ð}{ \pm}$ \\
\hline
\end{tabular}




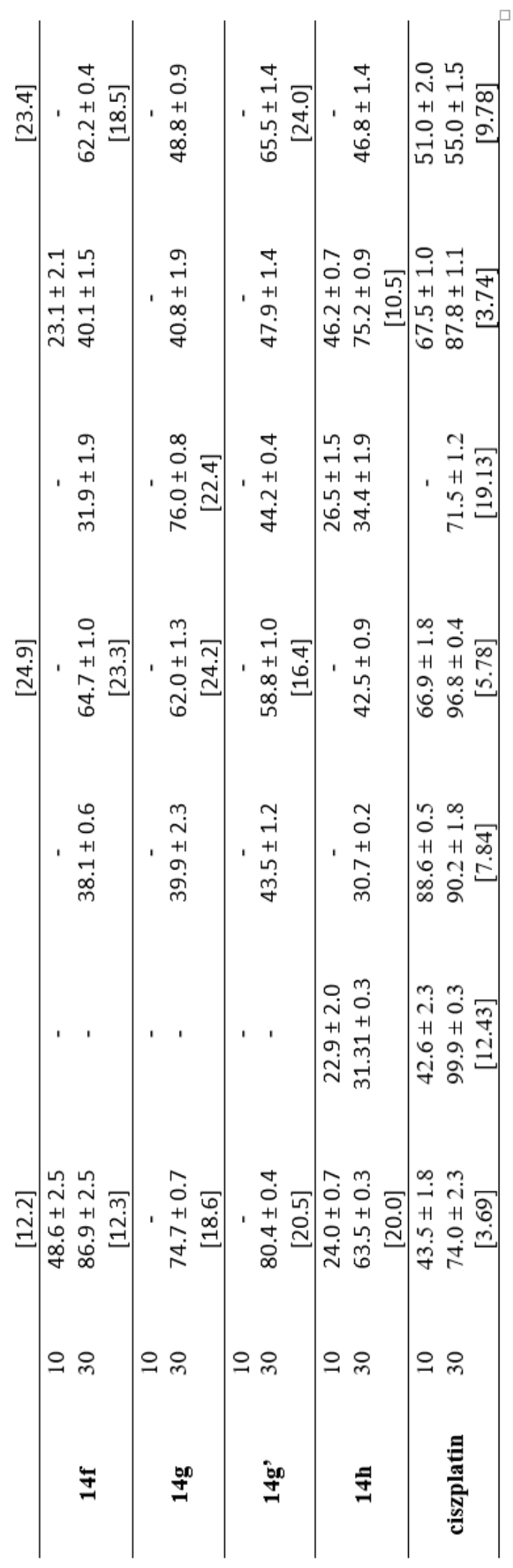




\begin{tabular}{|c|c|c|c|c|c|}
\hline \multirow{2}{*}{ Származék } & \multirow{2}{*}{$\mathrm{R}$} & \multirow{2}{*}{$\begin{array}{c}\text { Konc. } \\
\mu \mathrm{M}\end{array}$} & \multicolumn{3}{|c|}{ Gátlás $(\%) \pm \mathrm{SEM}^{\mathrm{a}}$} \\
\hline & & & MCF7 & $\mathrm{T} 47 \mathrm{D}$ & MDA-MB-231 \\
\hline \multirow{2}{*}{ 19a } & \multirow{4}{*}{$\mathrm{H}$} & 10 & $37.5 \pm 1.9$ & $67.5 \pm 1.1$ & $49.4 \pm 0.9$ \\
\hline & & 30 & $39.6 \pm 1.7$ & $73.8 \pm 1.0$ & $69.0 \pm 2.1$ \\
\hline \multirow{2}{*}{$20 \mathrm{a}$} & & 10 & $-\mathrm{b}$ & $36.9 \pm 1.5$ & - \\
\hline & & 30 & - & $46.7 \pm 2.3$ & $27.8 \pm 2.1$ \\
\hline \multirow{2}{*}{$19 b$} & \multirow{4}{*}{$\mathrm{CH}_{3}$} & 10 & $56.3 \pm 1.1$ & $64.9 \pm 2.0$ & $70.8 \pm 1.2$ \\
\hline & & 30 & $71.3 \pm 0.7$ & $81.6 \pm 2.5$ & $90.6 \pm 0.5$ \\
\hline \multirow{2}{*}{$20 b$} & & 10 & $41.2 \pm 2.4$ & $42.5 \pm 1.6$ & - \\
\hline & & 30 & $75.7 \pm 1.0$ & $69.6 \pm 0.7$ & $57.8 \pm 1.2$ \\
\hline \multirow{2}{*}{$19 \mathrm{c}$} & \multirow{4}{*}{$\mathrm{OMe}$} & 10 & $52.9 \pm 1.1$ & $60.4 \pm 2.9$ & $48.3 \pm 0.7$ \\
\hline & & 30 & $57.9 \pm 1.2$ & $69.9 \pm 1.5$ & $80.3 \pm 1.2$ \\
\hline \multirow{2}{*}{ 20c } & & 10 & $43.1 \pm 1.1$ & $47.7 \pm 1.2$ & $34.6 \pm 1.4$ \\
\hline & & 30 & $88.2 \pm 1.0$ & $66.2 \pm 2.5$ & $91.5 \pm 0.6$ \\
\hline \multirow{2}{*}{ 19d } & \multirow{4}{*}{$\mathrm{F}$} & 10 & $38.9 \pm 0.9$ & $47.2 \pm 1.6$ & $25.8 \pm 2.2$ \\
\hline & & 30 & $76.6 \pm 0.6$ & $71.6 \pm 2.4$ & $91.1 \pm 1.7$ \\
\hline \multirow{2}{*}{ 20d } & & 10 & $46.9 \pm 1.4$ & $31.7 \pm 2.4$ & $37.5 \pm 2.0$ \\
\hline & & 30 & $84.8 \pm 2.9$ & $56.9 \pm 1.4$ & $93.6 \pm 0.7$ \\
\hline \multirow{2}{*}{$19 e$} & \multirow{4}{*}{$\mathrm{Cl}$} & 10 & - & $54.4 \pm 1.5$ & - \\
\hline & & 30 & $77.9 \pm 0.7$ & $91.9 \pm 0.8$ & $86.4 \pm 1.1$ \\
\hline \multirow{2}{*}{$20 \mathrm{e}$} & & 10 & $32.6 \pm 1.6$ & $50.2 \pm 1.6$ & $45.8 \pm 2.0$ \\
\hline & & 30 & $81.2 \pm 0.2$ & $93.8 \pm 0.5$ & $93.9 \pm 1.4$ \\
\hline \multirow{2}{*}{$19 f$} & \multirow{4}{*}{$\mathrm{Br}$} & 10 & - & $56.7 \pm 1.1$ & - \\
\hline & & 30 & $79.3 \pm 0.8$ & $92.3 \pm 0.5$ & $89.5 \pm 0.5$ \\
\hline \multirow{2}{*}{$20 f$} & & 10 & $27.4 \pm 2.3$ & $36.2 \pm 0.7$ & $31.7 \pm 1.5$ \\
\hline & & 30 & $77.2 \pm 0.5$ & $79.9 \pm 0.9$ & $91.5 \pm 1.4$ \\
\hline \multirow{2}{*}{$19 \mathrm{~g}$} & \multirow{4}{*}{$\mathrm{CN}$} & 10 & $49.1 \pm 1.1$ & $87.4 \pm 0.9$ & $52.1 \pm 1.4$ \\
\hline & & 30 & $59.4 \pm 1.0$ & $90.9 \pm 0.4$ & $77.9 \pm 0.3$ \\
\hline \multirow{2}{*}{$20 \mathrm{~g}$} & & 10 & - & - & - \\
\hline & & 30 & $39.3 \pm 2.7$ & $34.9 \pm 1.6$ & $79.9 \pm 0.9$ \\
\hline \multirow{2}{*}{$19 h$} & \multirow{2}{*}{$\mathrm{NO}_{2}$} & 10 & $44.2 \pm 1.2$ & $43.3 \pm 2.8$ & $63.7 \pm 1.5$ \\
\hline & & 30 & $81.5 \pm 0.9$ & $72.8 \pm 1.7$ & $94.6 \pm 0.6$ \\
\hline \multirow{2}{*}{ ciszplatin $^{c}$} & \multirow[b]{2}{*}{-} & 10 & $66.9 \pm 1.8$ & $51.0 \pm 2.0$ & - \\
\hline & & 30 & $96.8 \pm 0.4$ & $57.9 \pm 1.4$ & $71.7 \pm 1.2$ \\
\hline
\end{tabular}




\begin{tabular}{|c|c|c|c|c|c|}
\hline \multirow{2}{*}{ Származék } & \multirow{2}{*}{$\mathrm{R}$} & \multirow{2}{*}{$\begin{array}{c}\text { Konc. } \\
\mu \mathrm{M}\end{array}$} & \multicolumn{3}{|c|}{ Gátlás $(\%) \pm \mathrm{SEM}^{\mathrm{a}}$} \\
\hline & & & MCF7 & $\mathrm{T} 47 \mathrm{D}$ & MDA-MB-231 \\
\hline \multirow{2}{*}{$\mathbf{8 a}$} & \multirow{4}{*}{$\mathrm{H}$} & 10 & $60.5 \pm 0.7$ & $36.4 \pm 3.1$ & $76.5 \pm 2.4$ \\
\hline & & 30 & $81.4 \pm 1.1$ & $80.5 \pm 1.1$ & $81.1 \pm 1.0$ \\
\hline \multirow{2}{*}{$9 \mathbf{a}$} & & 10 & $-\mathrm{b}$ & - & - \\
\hline & & 30 & $31.4 \pm 0.7$ & $43.4 \pm 0.8$ & - \\
\hline \multirow{2}{*}{$\mathbf{8 b}$} & \multirow{4}{*}{$\mathrm{CH}_{3}$} & 10 & $71.2 \pm 1.3$ & $34.2 \pm 2.4$ & $71.3 \pm 2.7$ \\
\hline & & 30 & $83.9 \pm 0.8$ & $84.0 \pm 0.6$ & $78.8 \pm 1.3$ \\
\hline \multirow{2}{*}{$9 b$} & & 10 & - & - & - \\
\hline & & 30 & $41.9 \pm 1.2$ & $35.4 \pm 2.1$ & $34.4 \pm 0.8$ \\
\hline \multirow{2}{*}{$8 c$} & \multirow{4}{*}{$\mathrm{OMe}$} & 10 & - & $33.0 \pm 1.7$ & $63.1 \pm 1.3$ \\
\hline & & 30 & - & $76.8 \pm 0.6$ & $66.3 \pm 1.1$ \\
\hline \multirow{2}{*}{$9 c$} & & 10 & - & $30.3 \pm 2.5$ & - \\
\hline & & 30 & $74.5 \pm 0.8$ & $85.7 \pm 0.8$ & $86.6 \pm 0.6$ \\
\hline \multirow{2}{*}{$8 d$} & \multirow{4}{*}{$\mathrm{F}$} & 10 & $84.4 \pm 1.2$ & $53.5 \pm 1.4$ & $84.1 \pm 1.1$ \\
\hline & & 30 & $92.6 \pm 0.3$ & $83.0 \pm 1.2$ & $91.6 \pm 0.8$ \\
\hline \multirow{2}{*}{$9 d$} & & 10 & - & - & - \\
\hline & & 30 & $26.4 \pm 2.5$ & $54.4 \pm 1.2$ & $42.8 \pm 3.3$ \\
\hline \multirow{2}{*}{$8 \mathrm{e}$} & \multirow{4}{*}{$\mathrm{Cl}$} & 10 & $55.0 \pm 0.9$ & $41.3 \pm 2.3$ & $62.9 \pm 1.1$ \\
\hline & & 30 & $81.3 \pm 1.5$ & $60.9 \pm 2.3$ & $68.0 \pm 0.8$ \\
\hline \multirow{2}{*}{$9 e$} & & 10 & - & - & - \\
\hline & & 30 & $45.2 \pm 1.4$ & $50.6 \pm 1.7$ & - \\
\hline \multirow{2}{*}{$8 f$} & \multirow{4}{*}{$\mathrm{Br}$} & 10 & $42.7 \pm 1.2$ & - & $43.2 \pm 1.2$ \\
\hline & & 30 & $68.6 \pm 1.4$ & $32.0 \pm 2.2$ & $70.7 \pm 1.7$ \\
\hline \multirow{2}{*}{ 9f } & & 10 & - & - & - \\
\hline & & 30 & $70.8 \pm 1.0$ & $81.7 \pm 1.9$ & $52.0 \pm 1.2$ \\
\hline \multirow{2}{*}{$8 g$} & \multirow{4}{*}{$\mathrm{CN}$} & 10 & - & $28.8 \pm 3.0$ & - \\
\hline & & 30 & $41.0 \pm 1.7$ & $42.9 \pm 0.6$ & $42.6 \pm 3.0$ \\
\hline \multirow{2}{*}{$9 \mathrm{~g}$} & & 10 & - & $26.7 \pm 2.6$ & - \\
\hline & & 30 & $40.2 \pm 1.7$ & $38.5 \pm 1.4$ & $25.7 \pm 1.9$ \\
\hline \multirow{2}{*}{$8 \mathrm{~h}$} & \multirow{4}{*}{$\mathrm{NO}_{2}$} & 10 & - & $32.2 \pm 2.0$ & - \\
\hline & & 30 & - & $29.1 \pm 1.7$ & - \\
\hline \multirow{2}{*}{$9 h$} & & 10 & - & - & - \\
\hline & & 30 & - & - & - \\
\hline & & 10 & $66.9 \pm 1.8$ & $51.0 \pm 2.0$ & - \\
\hline ciszplatin $^{c}$ & - & 30 & $96.8 \pm 0.4$ & $57.9 \pm 1.4$ & $71.7 \pm 1.2$ \\
\hline
\end{tabular}




\begin{tabular}{ccccc}
\hline & \multicolumn{3}{c}{ Viabilitás (\%) } \\
\cline { 2 - 5 } Származék & DU 145 & PC-3 & MCF-7 & MRC-5 \\
\hline $\mathbf{2 5 a}$ & 19.99 & 26.78 & 37.37 & 17.85 \\
$\mathbf{2 5 b}$ & 45.82 & 35.39 & 72.04 & 99.25 \\
$\mathbf{2 6 a}$ & 100.00 & 74.98 & 107.17 & 100.00 \\
$\mathbf{2 6 i}$ & 58.38 & 4.35 & 37.65 & 4.33 \\
$\mathbf{2 6 h}$ & 18.28 & 12.76 & 54.66 & 52.82 \\
$\mathbf{2 6 g}$ & 13.86 & 24.10 & 68.96 & 23.07 \\
$\mathbf{2 6 f}$ & 100.00 & 49.21 & 75.59 & 93.01 \\
$\mathbf{2 6 d}$ & 22.79 & 27.25 & 36.25 & 67.62 \\
$\mathbf{2 8 a}$ & 0.68 & 2.01 & 2.90 & 2.34 \\
$\mathbf{2 9 a}$ & 98.81 & 84.69 & 71.67 & 59.12 \\
$\mathbf{2 8 g}$ & 1.14 & 2.68 & 1.12 & 2.34 \\
$\mathbf{2 9 g}$ & 53.38 & 47.53 & 40.08 & 36.23 \\
$\mathbf{2 8 f}$ & 0.91 & 2.34 & 1.03 & 2.34 \\
$\mathbf{2 9 f}$ & 62.92 & 57.24 & 54.47 & 70.84 \\
$\mathbf{2 8 d}$ & 2.50 & 2.34 & 2.15 & 2.70 \\
$\mathbf{2 9 d}$ & 71.78 & 76.66 & 69.14 & 62.55 \\
$\mathbf{2 8 b}$ & 0.68 & 2.34 & 1.03 & 1.62 \\
$\mathbf{2 9 b}$ & 54.29 & 32.47 & 38.03 & 38.39 \\
$\mathbf{2 8 c}$ & 0.91 & 2.34 & 1.12 & 2.16 \\
$\mathbf{2 9 c}$ & 43.84 & 23.77 & 29.90 & 24.15 \\
$\mathbf{2 8 e}$ & 0.91 & 2.68 & 1.31 & 2.88 \\
$\mathbf{2 9 e}$ & 68.82 & 77.99 & 62.98 & 51.55 \\
\hline
\end{tabular}

